\title{
Perfumed Pineries
}

Environmental history of Australia's Callitris forests

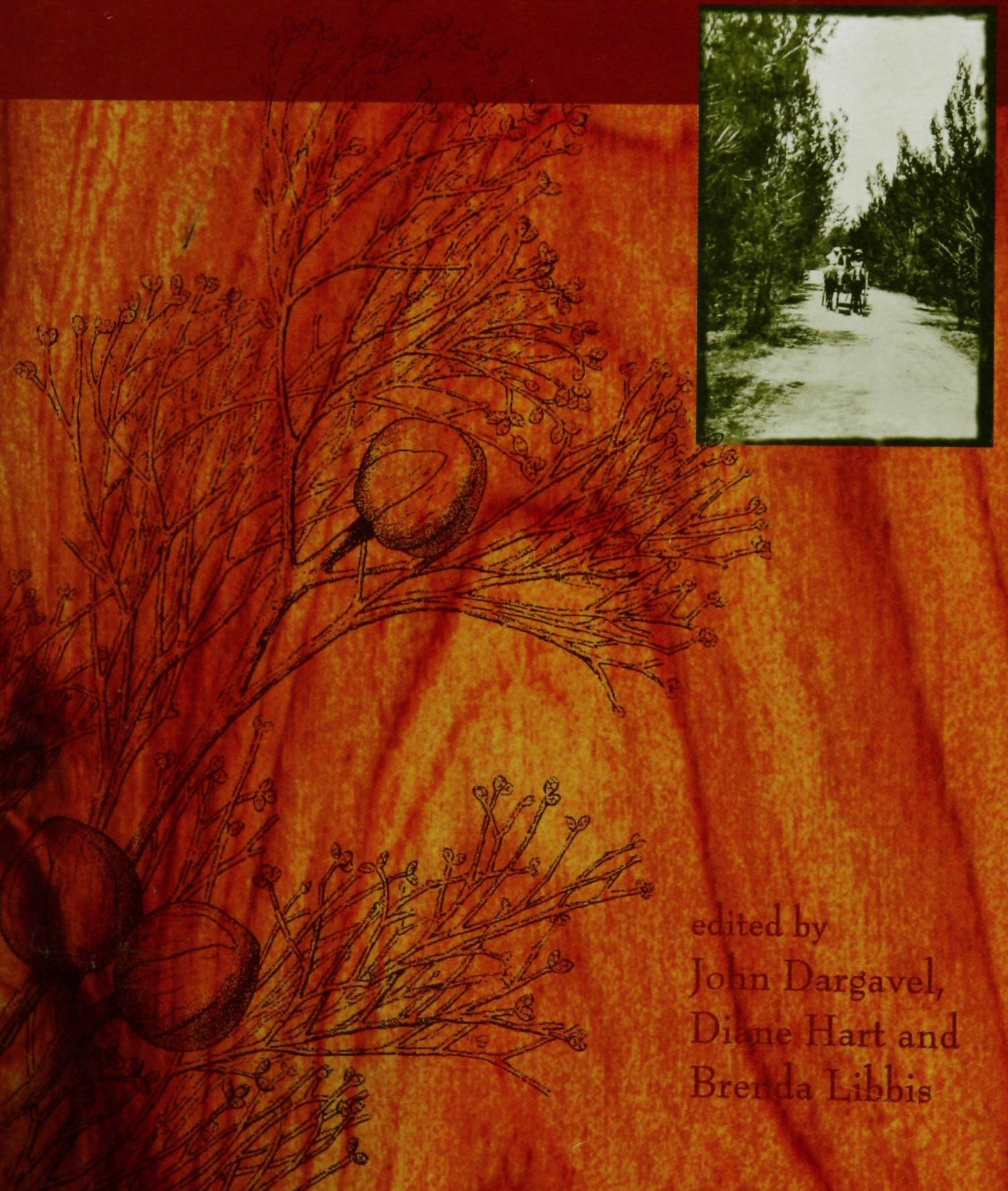



Perfumed Pineries 



\section{Perfumed Pineries}

Environmental history of Australia's Callitris forests
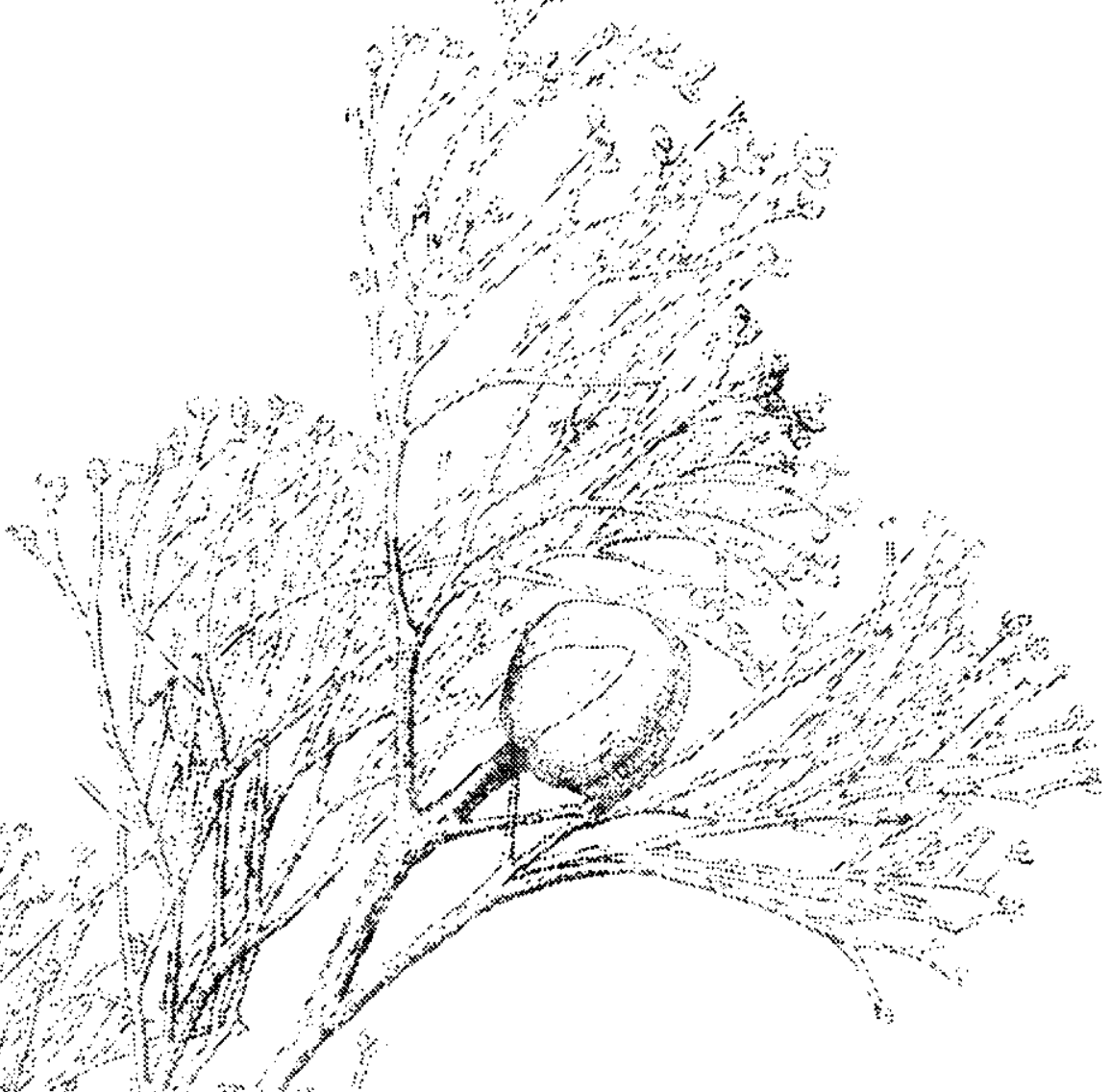

W'

$3 \%$

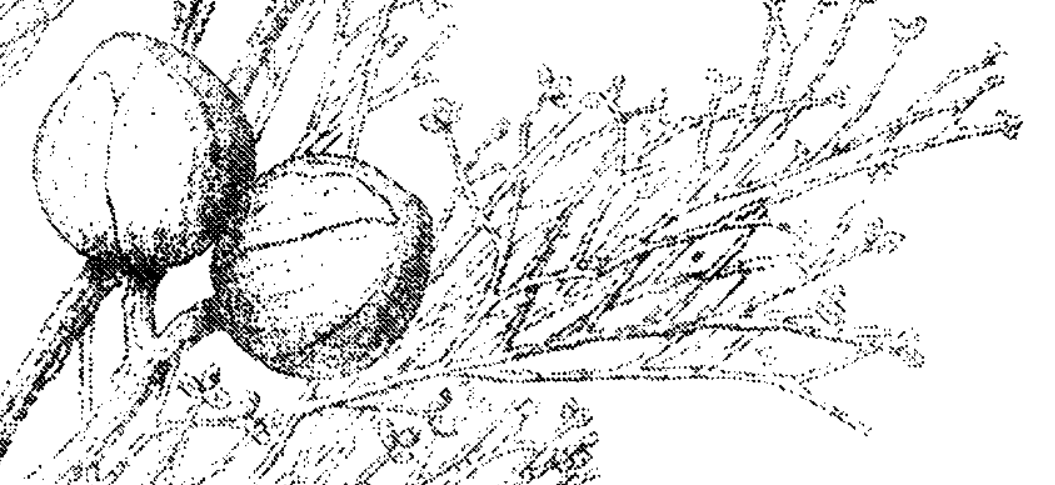

edited by

John Dargavel,

Diane Hart and

Brenda Libbis 


\section{Published by}

Centre for Resource and Environmental Studies,

The Australian National University

in association with Australian Forest History Sociery Inc. and

Department of Physical Geography, Macquarie University

The publishing program of the Centre for Resource and Environmental Studies is designed to present the results of the Centre's research and the proceedings of conferences and workshops. Views expressed in CRES publications are the views of the authors and are not necessarily those of the Centre or any associated institution.

Director: Prof. R.J. Wasson

Executive Officer: Valda Semets

Publications: McComas Taylor

(C) in this collection, CRES 2001

(C) in the papers, the authors 2001

ISBN 0867405244

This book is copyright. Apart from any fair dealing for the purposes of study, research, criticism or review as permitted under the Copyright Act, no part may be reproduced by any process without permission. Enquiries should be made to the publisher.

All CRES publications are available from:

Publications Section

Centre for Resource and Environmental Studies

Australian National University

Canberra ACT 0200

Tel. 0261254277

Fax 0261250757

Email: publications@cres.anu.edu.au

URL: cres.anu.edu.au

Cover design: Fiona Edge, DesignEdge, Dickson, ACT, from images of the wood of Callitris glaucophylla; illustrations of Callitris species in J.H. Maiden, Forest flora of New South Wales, 1917, and a photograph of 'Callitris arenosa A.Cunn., Brunswick Heads, N.E. New South Wales' reproduced from R.T. Baker and H.G. Smith, $A$ research on the pines of Australia, 1910, p.161.

Printed by Instant Colour Press Pty Ltd, Belconnen, ACT. 


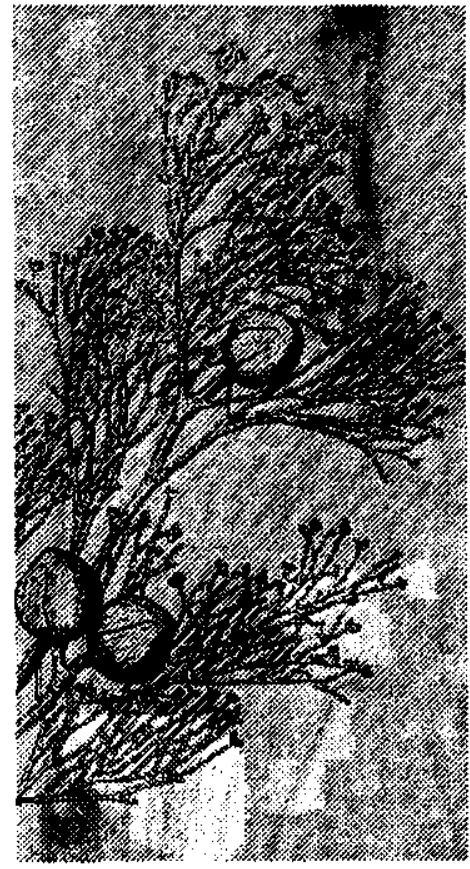

Contents

List of Authors

Preface

1 Palynology of the perfumed pineries of arid South Australia Jon Luly

2 Callitris and the botanists

Sybil Jack

3 A history of the wood anatomy of Callitris

Roger Heady

4 Dendrochronology of Australian cypress pines Jobn Banks and Ian Pulsford

5 A new technique in dendroecology using Callitris Mathew Searson and Stuart Pearson

6 Identifying a white pine-ironbark community from phytoliths Diane M. Hart

$7 \quad$ Assessing changes in cypress pine forests from old stumps Ian Lunt, David Parker and Wayne Robinson

8 Stump count analysis of the pre-European Pilliga forests 
9 Soil, vegetation and landform in Pilliga East State Forest

Geoff Humphreys, Elizabeth Norris, Paul Hesse, Diane Hart, Peter Mitchell, Peter Walsh and Russell Field

10 Pilliga landscapes, Quaternary environment and geomorphology

Paul Hesse and Geoff Humphreys

11. Litterfall and decomposition in a white pine-ironbark community

Diane $M$. Hart

12 Koala populations in the Pilliga forests

Rod Kavanagh and Elizabeth Barrott

13 Floristic patterns in the Pilliga

Doug Binns and Doug Beckers

14 The 'frontier': Callitris intratropica and landscape change

David Bowman

15 Perfumed pine and the pioneers

Bob McKillop

16 Recent disturbances to Callitris forests in Southern Queensland Mark Harris and David Lamb

17 Management plans for cypress forests

John Dargavel and Margaret Kowald

18 Calculating sustained yields in New South Wales cypress forests, 1915 to 1957 Andrew Deane

19 A vanishing presence: Queensland forest heritage David Cameron

20 Disturbance history mapping in New South Wales

Pauline Curby, Michael O'Neill, Rhondda O'Neill and Patrick Tap

21 Regulating Callitris populations: a tale of two pineries James C. Noble

22 The writing of $A$ Million Wild Acres

Tom Grifiths

23 Perfumed pines: the exploited and the exploiter Eric Rolls 


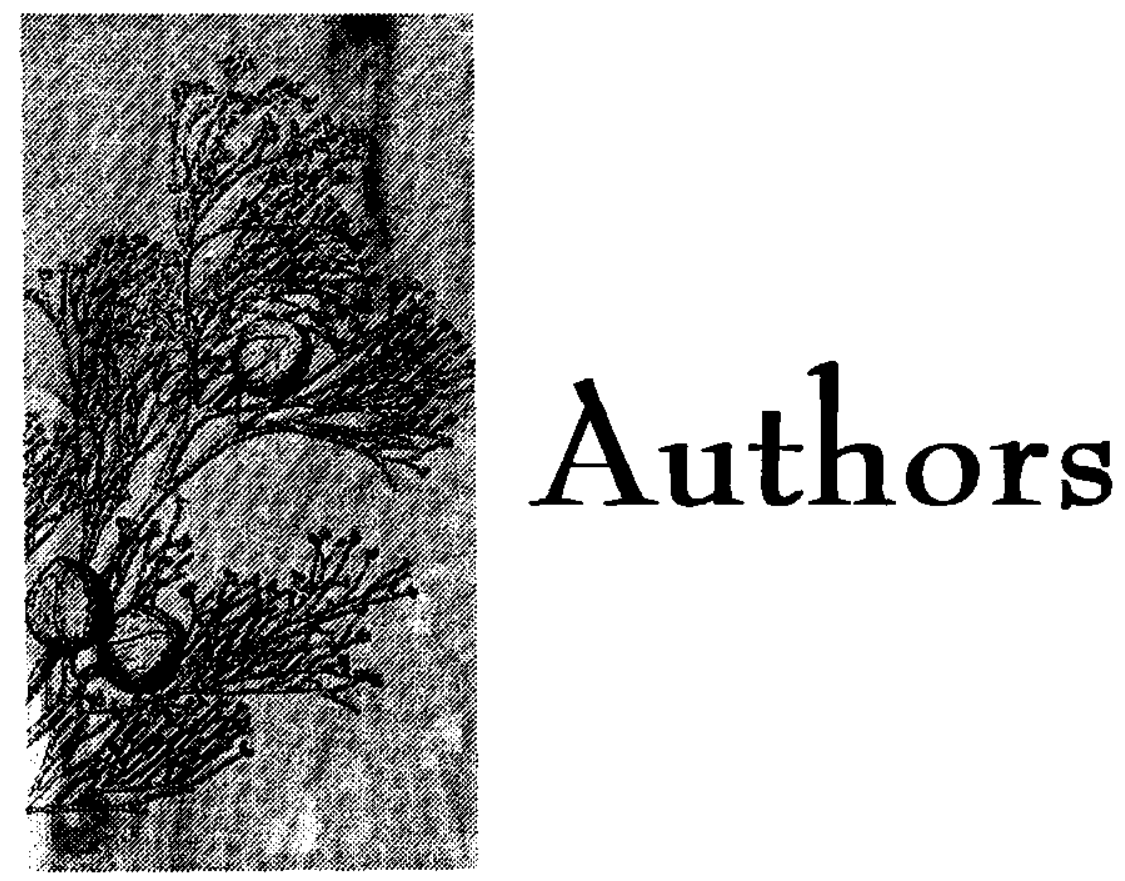

John Banks Department of Forestry,

The Australian National University, Canberra

Elizabeth Barrott School of Biological Sciences, University of Sydney

Doug Beckers National Parks and Wildlife Service, Dubbo, NSW

Doug Binns State Forests of New South Wales, Coffs Harbour, NSW

David Bowman Key Centre for Tropical Wildlife Management,

Northern Territory University, Darwin

David Cameron Forest Management,

Queensland Parks and Wildlife Service, Brisbane

Pauline Curby Cronulla, NSW

John Dargavel Department of Forestry and Centre for Resource and Environmental Studies, The Australian National University, Canberra

Andrew Deane State Forests of New South Wales, Bathurst, NSW

Russell Field Department of Physical Geography,

Macquarie University, Sydney

Diane M. Hart Department of Physical Geography, Macquarie University, Sydney

Mark Harris Department of Botany, University of Queensland, Brisbane

Roger Heady Department of Forestry and Electron Microscope Unit, The Australian National University, Canberra 
Paul Hesse Department of Physical Geography, Macquarie University, Sydney

Geoff Humphreys Department of Physical Geography,

Macquarie University, Sydney

Rod Kavanagh, Forest Research Division,

State Forests of New South Wales, Beecroft, NSW

Margaret Kowald Forest Management,

Queensland Parks and Wildlife Service, Brisbane.

Brenda Libbis Mt Waverley, Victoria

David Lamb Department of Botany, University of Queensland, Brisbane

Jon Luly

School of Tropical Environment Studies and Geography, James Cook University, Townsville, Queensland

Ian Lunt The Johnstone Centre for Social and Biophysical

Research, Charles Sturt University, Albury, NSW

Bob McKillop Castlecrag, NSW

Peter Mitchell Department of Physical Geography,

Macquarie University, Sydney

James C. Noble Sustainable Ecosystems, CSIRO, Canberra

Elizabeth Norris Department of Physical Geography,

Macquarie University, Sydney

Michael O'Neill Northern NSW Forestry Services, Casino, NSW

Rhondda O'Neill Northern NSW Forestry Services, Casino, NSW

David Parker The Johnstone Centre for Social and Biophysical

Research, Charles Sturt University, Albury, NSW

David Paull School of Biological Sciences,

University of New England, Armidale, NSW

Stuart Pearson School of Geoscience, University of Newcastle, NSW

Ian Pulsford National Parks and Wildlife Service, Queanbeyan, NSW

Wayne Robinson The Johnstone Centre for Social and Biophysical

Research, Charles Sturt University, Albury, NSW

Eric Rolls North Haven, NSW

Mathew Searson School of Geoscience, University of Newcastle, NSW

Patrick Tap State Forests of New South Wales, Dubbo, NSW

Peter Walsh Department of Physical Geography,

Macquarie University, Sydney 


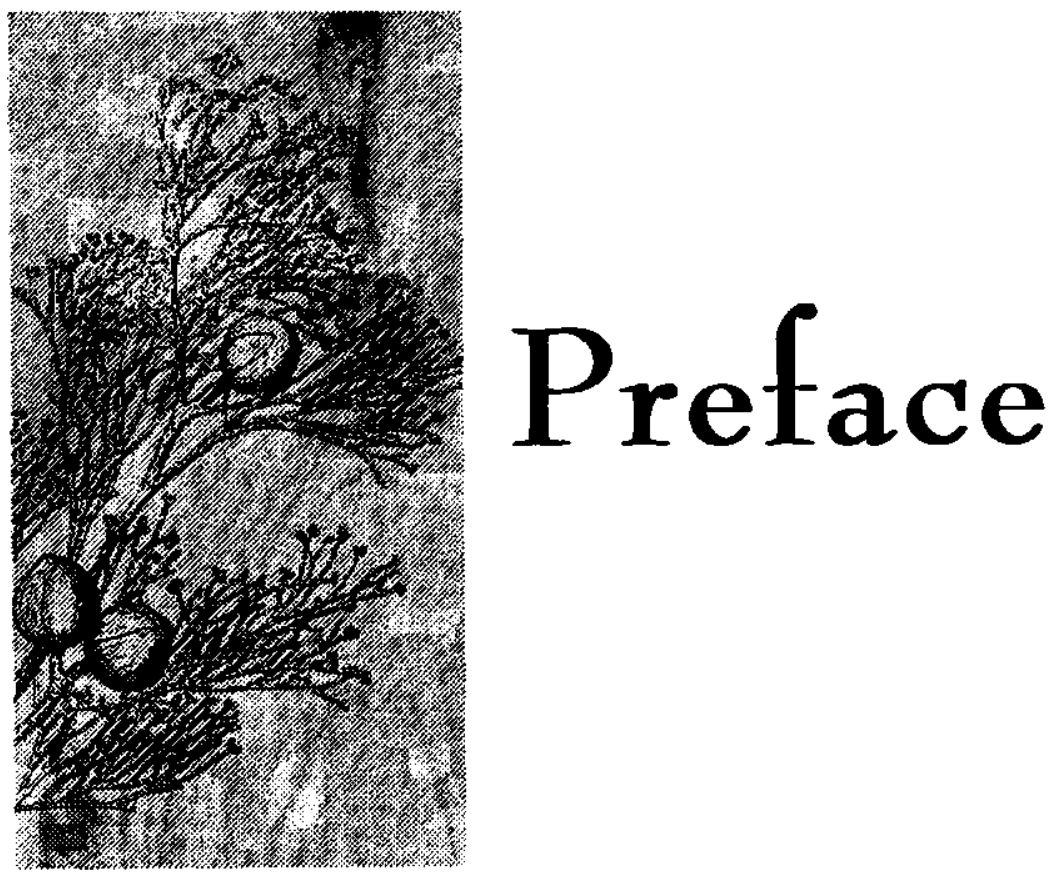

The perfumed pineries have survived heat, aridity and cold in Australia for at least a million years. They range from semi-arid scrublands to tropical woodlands. The first people named the trees: munlarru, marung, marinhi, pimba or binba, gurraay, jinchilla, karapaarr and puratharr, kulilypuru or kuli, karntirrikani, and more, each particular to people and place. European settlers called them pine: Oyster Bay, Port Macquarie, Murray River, white, black and several more. Botanists placed them in a genus they first called Frenela. Now it is Callitris with fifteen species spread across Australia and two in New Caledonia. They yield termite-resistant timber for houses, fences, poles or mines. They produce blue and green oils for aromatherapy and a resin whose collection, we think, once prompted the famous forester, Harold Swain, to call them the 'perfumed pineries' of our title. Their greatest forest is the Pilliga of New South Wales-A Million Wild Acres to the many readers of Eric Rolls' evocative history.

The perspectives on their history are as diverse as their names. Authors, botanists, ecologists, geographers, many other scientists, foresters, historians, landowners and managers all have different truths to tell, and different ways of telling them. In November 2000 they were brought together for the first time in a conference in Coonabarabran, New South Wales. It was convened and supported jointly by the Australian Forest History Society, Inc.; the 
Centre for Resource and Environmental Studies, the Environmental History Project of the Research School of Social Studies and the Department of Forestry of the Australian National University; and the Department it Physical Geography of Macquarie University. This volume is the written outcome. It starts a new, comprehensive and collaborative phase in the study of Australia's Callitris forests.

Publications in the first phase collated botanical and utilitarian information. They were produced in Sydney during the 1910 s by Baker and Smith from the Technical Museum, and by Maiden from the Royal Botanic Gardens. At the same time, Swain was starting systematic timber assessment surveys and Jensen was examining 'The agricultural prospects and soils of the Pilliga Scrub'. He described the Pilliga as a 'region unexplored by geologists and other men of science, a terra incognita to all but a few stockmen'.

In publishing his study of the Pilliga in 1981, Rolls started a new phase that enlarged the scope of Australian forest history. For many of us, reading it brought about a desire to explore the forest physically and scientifically for ourselves. Since then, studies of Callitris have flourished in present and historical ecology, heritage studies, physical geography, forestry and much else. They have extended into regions far remote from the Pilliga. They continually raise new questions, challenge old assumptions and provide new insights into these intriguing forests.

The studies in this book cut time and place in different ways, defying neat arrangements and encouraging the reader to dip and probe. We have ordered them mainly by time. Some take the long perspective, reaching back into past pine environments. Others are set within the shorter time since European settlement. Studies about the natural history and physical geography of the Pilliga region have been placed together. The language of the studies presented here is as diverse as the topics. While most are straightforward, some need their specialist scientific terms explained in the glossary. And as a fitting finale to the collection, Eric Rolls tells 'stories of perfumed pines'. He reflects on the past uses of cypress, from infusions for diarrhoea to beautiful timber for building. His delight in being part of this 'celebration of the perfumed pineries' was echoed by all participants in the conference and is, we hope, conveyed in this collection of its papers.

Jobn Dargavel, Diane Hart and Brenda Libbis 


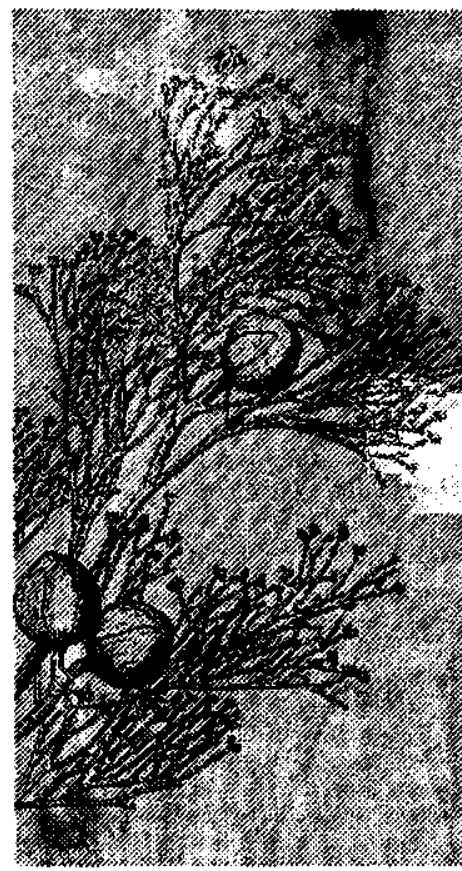

\title{
Palynology of the perfumed pineries of arid South Australia
}

\author{
Jon Luly
}

\section{Introduction}

On a continent seemingly overrun with eucalypts and wattles, the occurrence of occasional communities dominated by the native conifer, Callitris (Vent.) not only catches the eye but presents a tantalising challenge to the enterprising biogeographer. Equally, the tendency for Callitris woodlands to expand and thicken in some parts of their range, while retreating and fragmenting in others (Bowman and Panton 1993, Bowman et al. 1988) has inherent ecological interest which flows through into the management of those species of Callitris regarded in some circles as woody weeds of agricultural lands.

The diversity of environmental settings which support Callitris species is remarkable, ranging from the margins of wet tropical forests, through the monsoon tropics to southern coastal forests and heaths and to the arid and semi-arid woodlands where the genus comes into its own on light textured oligotrophic soils (Bowman and Harris 1995).

Recent palynological work in arid South Australia (Luly in press) indicates the mixed fortunes enjoyed by Callitris woodlands in the present day mirror those of earlier times, though for quite different reasons. This paper explores the turbulent times experienced by the 'perfumed pineries' in the vicinity of Lake Frome and Lake Eyre. 


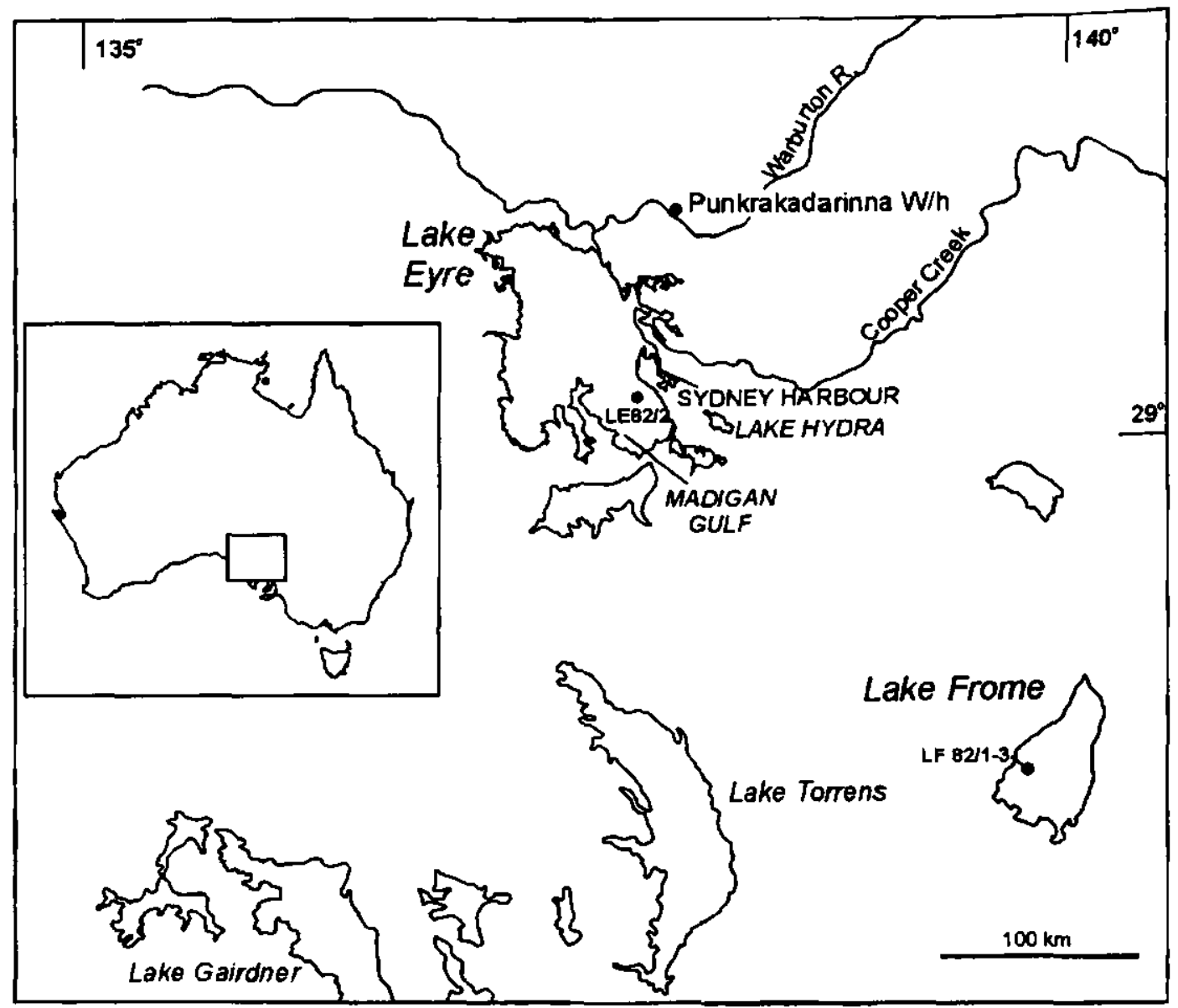

Figure 1. Site localities at Lake Eyre and Lake Frome.

\section{Sites}

Lakes Frome and Eyre are large salt lakes (playas) occupying slowly subsiding tectonic basins in the arid central north of South Australia (Figure 1). Lake Frome lies immediately east of the Flinders Ranges. It occasionally receives water as runoff from the Ranges and very rarely as overflow from Strzelecki Creek, but is dry and salt encrusted for most of the time. Although Lake Eyre lies at the terminus of a massive internal drainage system, it too is mostly dry. Major fillings of the lake occur, perhaps once a century, as a result of exceptional rainfall in the northern reaches of the catchment.

Vegetation patterns in the vicinity of Lake Frome reflect the interactions of arid climate, soil characteristics and topographic diversity. In the Flinders Ranges, Gell and Bickford (1996) recognise numerous, mostly Eucalyptus dominated communities, although cypress pine (Callitris glaucophylla) is a common component in many of the more mesic settings. It is four'd 
scattered through arid woodlands to the west of the lake and isolated senescent individuals survive on some of the rabbit ravaged islands on the lake floor. Callitris is missing from the dune fields to the east of Lake Frome.

In the drier environs of Lake Eyre, Callitris is notably absent from a regional vegetation dominated by grasslands and ephemeral herblands in desert dunefields, by sparse chenopod shrublands on clay flats and gibber plains, and by a well developed halophytic flora associated with lake basins and sites of saline groundwater outcrop. Eucalypts dominate riparian woodlands in the less saline reaches of major channels.

Pollen is discontinuously and sparsely preserved in arid zone environments. The Callitris story recounted here is based on palimpsests of pollen bearing material representing relatively wet intervals of time between periods with cold dry glacial environments which are periods of non-deposition or erosion and are thus palynological black holes. Lake Eyre and Lake Frome thus provide a series of snapshots of environments from late Tertiary time to the present.

At Lake Eyre a series of fluvio-lacustrine sequences are preserved in the lake basin and along the courses of Cooper Creek and the Diamantina River (Magee et al. 1995, Magee and Miller 1998). Sites of interest include 'Sydney Harbour' (a tributary arm of the lake), Punkrakadarinna Waterhole on the course of the Diamantina River and LE $82 / 2$, a core site on the bed of Madigan Gulf. At Lake Frome, the latest Pleistocene/Holocene sequence intersected in core LF 82/2 (Singh and Luly 1991) is of central importance as materials deposited in earlier lacustrine cycles have been removed by aeolian erosion during the rigours of Last Glacial Maximum aridity. There is only limited scope for preservation of sediment along the relatively minor drainages entering the lake.

\section{Pollen record}

Callitris pollen is rare in the older sediments in the region (Figure 2). It is completely absent from mid Miocene materials at Lake Palankarinna (Truswell and Harris 1982) though occasional grains are recorded in counts from materials of comparable age in the Wooltana Number 1 bore near Lake Frome (Martin 1990). It is virtually invisible in the basal Plio-Pleistocene horizons of the Sydney Harbour core which, in common with pollen assemblages from all of these early sites, is overwhelmingly dominated by pollen of the Casuarinaceae, with subsidiary contributions from a selection of hydrophilous graminoids (Luly in prep; Martin 2000) and a few other odd taxa left over from the Tertiary rainforests (Martin 2000). 


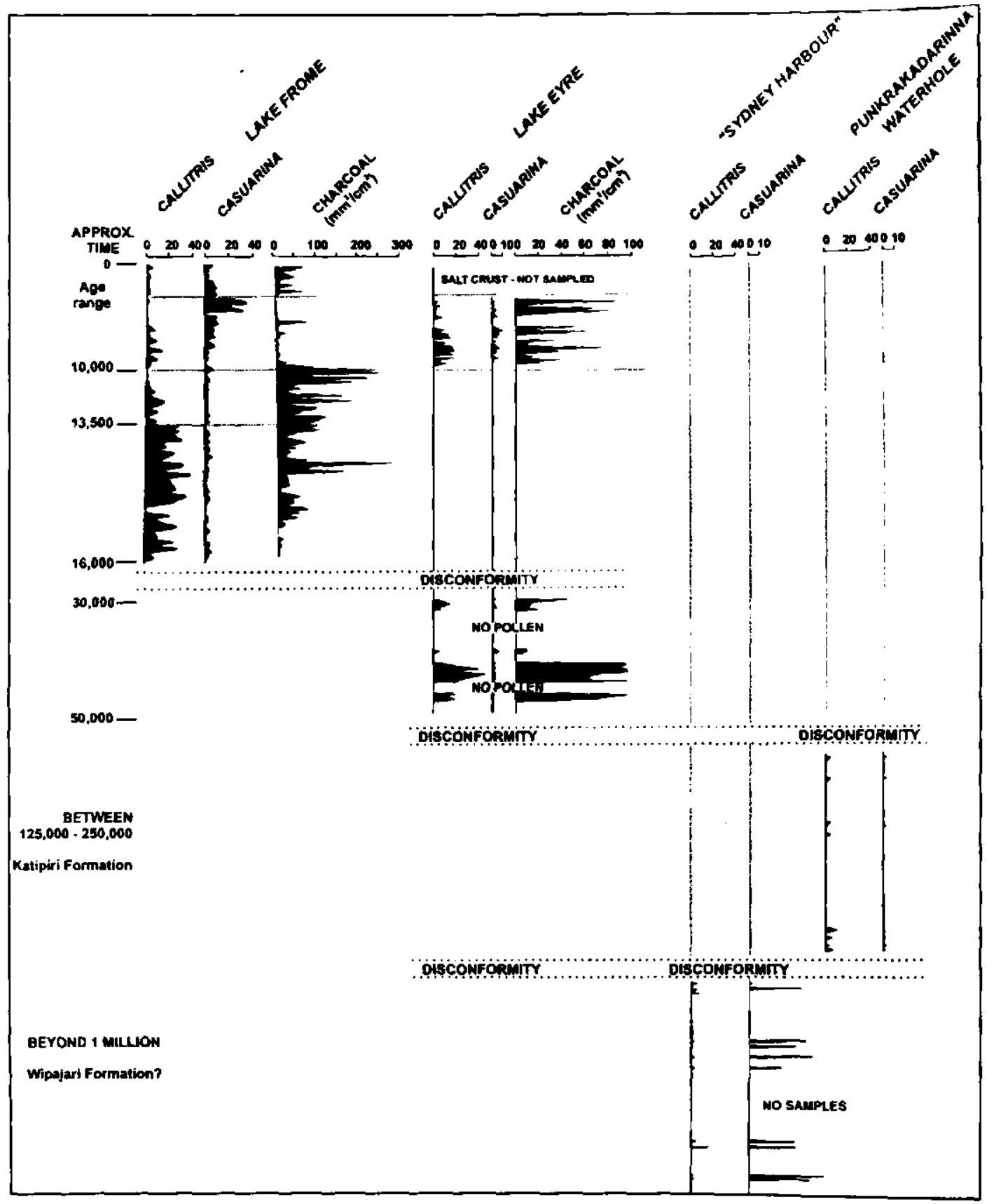

Figure 2. Summary of palynological events affecting the 'perfumed pineries' near Lake Frome and Lake Eyre.

Callitris pollen is also notably absent from the middle Pleistocene Katipiri formation sediments exposed at Punkrakadarinna Waterhole on the Diamantina River. There, despite indications of permanent deep water, pollen assemblages are characterised by an abundance of herbaceous forms, suggesting the extinct megafauna, whose bones litter the modern river bed, moved in a world of daisies, crucifers and grasses. 
The first detectable rise in Callitris pollen from the region occurs in the late Pleistocene sequence of LE 82/2, a core sampling basal sediments inside confines of the modern Lake Eyre. These materials have been dated to between 30000 and 50000 years before the present (BP) (Gillespie et al. 1991, Magee et al. 1995). The pollen assemblages they preserve are consistent with widespread occurrence of cypress pine woodlands in the regional vegetation. Sadly there is no way to judge what was happening around Lake Frome at this time.

The brief late Pleistocene exuberance of Callitris at Lake Eyre was brought to an end by climatic change. Cooling, drying and falling concentrations of atmospheric carbon dioxide destroyed tree dominated vegetation through much of Australia (Kershaw et al. 1994) the arid lands included. The reddening of sediments in the lake bed and accumulation of a thick halite crust speak eloquently of progressive desiccation and salinisation of the landscape. While it is impossible to determine exactly when Callitiris vanished, it had clearly done so well before the peak of the Last Glacial Maximum at about $18000 \mathrm{BP}$.

At Lake Frome, circumstances must have been comparable, as aeolian erosion of lake-floor sediments formed a complex of lunette forms which now fringe the lake yielding evidence of the effects of salt and aridity on this landscape too (Bowler et al. 1986). Here, however, the Flinders Ranges provided a refuge from the worst excesses of Last Glacial Maximum climate and though things were tough, Callitris survived in localised pockets and patches in much the same way as do the climatic relicts found through the MacDonnell or George Gill Ranges in central Australia today. With the amelioration of climate following the Last Glacial Maximum, these pockets allowed Callitris populations to recover and expand into regional landscapes.

At Lake Frome, expansion occurred early and quickly. By $16000 \mathrm{BP}$, when sedimentation in the lake basin resumed, Callitris dominates pollen assemblages and it seems certain that Callitris woodlands were the definitive tree communities of the time. At Lake Eyre, sedimentation did not resume until approximately $10000 \mathrm{BP}$ but even there, Callitris staged a rapid and substantial recovery with pollen frequencies consistent with the presence of a sparse but recognisable woodland.

These were good times for Callitris but they did not last. At Lake Frome, Callitris pollen frequencies declined precipitously between about $14000 \mathrm{BP}$ and $13000 \mathrm{BP}$, co-incident with a marked increase in charcoal particles in the sediment. At more or less the same time, archaeological evidence points to a revival in the fortunes of human populations in the region (Lampert and Hughes 1988) and the rise in charcoal occurrences probably reflect a more 
pronounced human influence on environmental affairs. From $10000 \mathrm{BI}$ the present day, Callitris has remained a relatively minor component of vegetation around the lake. At Lake Eyre, the Holocene decline occl closer to $5000 \mathrm{BP}$ (again co-incident with the appearance of an archaeolog1cally visible human presence around the lake-Veth et al. 1990), and the correspondence between the decline in Callitris and fluctuations in the charcoal signal is less pronounced. Isolated individual Callitris trees may have persisted until as late as 3000 or $4000 \mathrm{BP}$ around Lake Eyre but for the time being at least, their race is run.

\section{Synthesis}

Consideration of the pollen records from Lake Frome and Lake Eyre indicates Callitris has been a great survivor. The reconstructions offered here are necessarily speculative but at least provide an interpretative framework testable against records from potentially productive sites such as Lake Callabonna.

Plio-Pleistocene woody phases in the region were dominated by the Casuarinaceae, leaving Callitris to occupy localised refugial sites, much as appears to have been its fate throughout the Tertiary. Although the passing of Casuarinaceae dominated woodlands-perhaps consequent on rising salt levels in landscape (Crowley 1994) —opened a potential niche for the cypress pines it was not exploited. The reasons for this are unclear however it is at least possible that pressure exerted by the appetites of herbivorous megafauna, some of which have been found with Callitris in their gut cavity (Tedford 1973), kept tree taxa in general and Callitris in particular from prominence in arid zone landscapes. Removal of the megafauna prior to $50000 \mathrm{BP}$ (Miller et al. 1999) by means unknown released the pressure and Callitris rose to become the premier arid land tree taxon.

Climate change in the lead up to the Last Glacial Maximim dealt Callitris woodlands a decisive setback. Expansion from refugia in the Flinders Ranges was rapid once post-glacial climatic amelioration took effect but again, Callitris woodlands declined precipitously. This time, the decline occurs in parallel with archaeological indications of intensified human impact on regional landscapes and Aboriginal land management, especially through the use of fire, was probably a factor. If such a model stands scrutiny at other sites and in other sequences, it is nicely ironic that the survival of Callitris communities in fire prone sites today ultimately depeni on skilful application and management of fire in a way which maintail 
reproduces or mimics the traditional fire regimes employed by Aboriginal people.

\section{Acknowledgments}

It is a pleasure to acknowledge the contribution made to this work by John Magee, whose encyclopaedic investigations of the geology and geomorphology of Lake Eyre and Lake Frome underpin the reconstructions advanced here. I also thank Steve Webb for his enthusiastic proselytising on the effects of megafauna on vegetation in the Australian palaeoenvironmental context, not to mention his culinary achievements under less than ideal conditions.

\section{References}

Bowler, J. M., Huang Qi, Chen Kezao, Head, M.J. and Yuan Baoyin 1986. Radiocarbon dating of playa-lake hydrologic changes: examples form northwestem China and central Australia. Palaeogeograpby, Palaeoclimatology, Palaeoecology 54: 241-60.

Bowman, D. M. J. S. and Panton, W. J. 1993. Decline of Callitris intratropica R. T. Baker and H. G. Smith in the Northern Territory: implications for pre- and post-European fire regimes. Journal of Biogeograpby 20: 373-81.

Bowman, D. M. J. S. and Harris, S. 1995. Conifers of Australia's dry forests and open woodlands. In Enright, N. J. and Hill, R. S. (eds), Ecology of Soutbern Conifers. Melboume University Press: 252-70.

Bowman, D. M.J. S., Wilson, B. A. and Davis, G. W. 1988. Response of Callitris intratropica R. T. Baker and H. G. Smith to fire protection, Murgenella, northern Australia. Australian Journal of Ecology 13: 147-59.

Crowley, G. M. 1994. Groundwater rise, soil salinisation and the decline of Casuarina in southeastern Australia during the Quaternary. Australian Joumal of Ecology 19: 417-24.

Gell, P.A. and Bickford, S. 1996. Vegetation. In Davies, M., Twidale, C. R and Tyler, M. J. (eds), Natural History of the Flinders Ranges. Royal Society of South Australia: 86-101.

Gillespie, R., Magee, J. W., Luly, J. G., Sparks, R. J. and Wallace, G. 1991. AMS radiocarbon dating in the study of arid environments: examples from Lake Eyre, South Australia. Palaeogeograpby, Palaeoclimatology, Palaeoecology 84: 75-86.

Kershaw, A. P., Martin, H. A. and Mc Ewen-Mason, J.R.C. (1994) The Neogene: a period of transition. In Hill, R S. (ed), History of the Australian Vegetation: Cretaceous to Recent. Melboume: Cambridge University Press: 299-327.

Lampert, R. J. and Hughes, P.J. 1988. Early human occupation of the Flinders Ranges. Records of the South Australion Museum 22: 139-68.

Luly, J. G. in press. On the equivocal fate of Late Pleistocene Callitris Vent. (Cupressaceae) woodlands in arid South Australia. Quatemary International

Luly, J. G. in prep. Plio-Pleistocene palaeoenvironments at Lake Hydra, arid South Australia. 
Magee, J. W. and Miller, G. H. 1998. Lake Eyre palaeohydrology from 60 ka to the pres: beach ridges, and glacial maximum aridity. Paloeogeography, Palaeoclimatology, Palaeoect 144: 307.29.

Magee, J. W., Bowler, J. M., Miller, G. H., and Williams, D. L. G. 1995. Stratigrapl sedimentology, chronology and palaeohydrology of Quaternary lacustrine sediments Madigan Gulf, Lake Eyre, South Australia. Palaeogeography, Palaeoclimatology, Palaeoecology 113: 3-42.

Martin, H. A. 1990. The palynology of the Namba Formation in the Wooltana-1 bore, Callabonna Basin (Lake Frome) South Australia and its bearing on grasslands in central Australia. Alcheringa 14: 247-55.

Martin, H. A. 2000. Re-assignment of the affinities of the fossil pollen type Tricolites trioblatus Mildenhall and Pocknell to Wilsonia (Convolvulaceae) and a reassessment of the ecological interpretations. Review of Palaeobotany and Palynology 111: 237-51.

Miller, G. H., Magee, J. W., Johnson, B. J., Fogel, M. L., Spooner, N. A., McCulloch, M.T. and Ayliffe, L. K 1999. Pleistocene extinction of Genyomis newtoni: human impact on Australian megafauna. Science 283: 205-8.

Singh, G. and Luly, J. G. 1991. Changes in vegetation and seasonal palaeoclimate since the last giacial maximum at Lake Frome, South Australia. Palaeogeograpby, Palaeoclimatology, Palaeoecology 84: 75-86.

Tedford, R. H. 1973. The Diprotodons of Lake Callabonna. Australian Natural History 17: 349-54.

Truswell, E. M. and Harris, W. K. 1982. The Cainozoic palaeobotanical record in arid Australia: fossil evidence for an arid-adapted flora. In Barker, W. R and Greenslade, P.J.M. (eds), Evolution of the Flora and Fauna of Arid Australia. Adelaide: Peacock Publications: 67-76.

Veth, P., Hamm, G. and Lampert, R J. 1990. The archaeological significance of the Lower Cooper Creek. Records of the South Australian Museum 24: 43-66. 

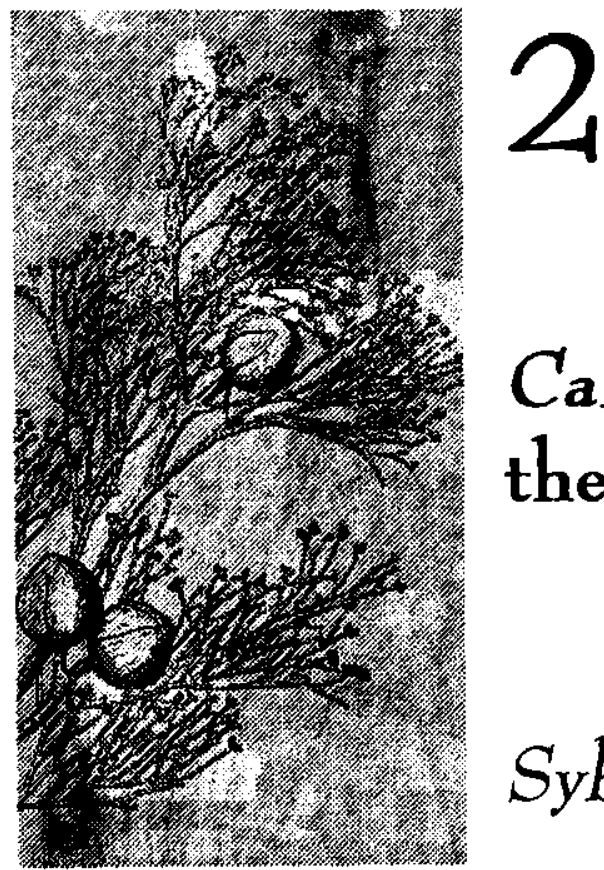

\section{Callitris and the botanists}

\section{Sybil Jack}

When eighteenth and early nineteenth century botanists discovered how different the flora and fauna were in Australia from those in the Old or even in the New World, they had to fit this into their conventionally received ideas about world history, natural history and philosophy. The Flood was a matter of faith to all Christian traditions and until the 1830s most geologists divided history into ante-diluvian and post-diluvian. The floristic distinctiveness of Australia did little to shake this belief. The subsequent history of botanical study of Callitris reflects the changes which developed in the general botanical understanding of the history of plants and the way in which particular floristic regions came into existence. The strange flora and fauna of Australia, which Smith described as 'all ... new and wonderful to the botanist', were slowly identified and classified. Amongst the British it appears to be Brown and Cunningham who found species of Callitris. As they were ship's botanists, they were coastal ones, but French explorers had made their own discoveries and it was E.P. Ventenat in 1808 who publicly established Callitris as a genus, although apparently without specifying the species he was examining. The director of the Paris Herbarium, finding this a name too close to Calythrius, substituted Frenela in honour of an eminent French natural philospher. Frenela was generally used until the later nineteenth century. 
Those altering the botanical system in the nineteenth century largely ignored what had, or might have happened in the Southern Hemisphere. The classification and explanation of Australian flora was in the hands of outsiders from the Northern Hemisphere who confined themselves to fitting the peculiarities of the southern flora into a northern taxonomy. Robert Brown, whose collection was claimed to be the main foundation of western knowledge of Australian vegetation (Brown 1810), and Alan Cunningham, who was botanist aboard King's expeditions and got inland as far as the Macquarie marshes where he found both the white and the black Callitris, played an important part in the early identification of the different Callitris species.

By the mid-century, when most geologists had abandoned the attempt to reconcile their theories with the Bible, and when palaeontology was producing more and more evidence of a long history of extinct species, the theories of Lamarck and Darwin were beginning to influence those working with Australian material. Joseph Dalton Hooker speculated on the possibility that plants of the southern ocean were the remains of a flora once spread over a larger more continuous tract of land of which Antarctica, Australia and southern America were part. He increasingly saw little fixity in genera and species, describing genera and orders as arbitrary (Hooker 1860, Introduction). Once Darwin's Origins of species was in print, Hooker drew out the botanical evidence. In his introductory essay on the flora of Tasmania he attempted to explain the origin and development of the Australian flora in evolutionary terms, which is thought to be the first botanical use of the idea in print. He was developing a reputation as the expert on the geographical distribution of plants - that almost keystone of the laws of creation' - and found the distribution of the Coniferae odd.

He gives a resumé of Brown, Mirbel, Spach and Hoffmeister in his general description of Frenela, claiming that the Australian Frenelae represented the Juniperi and Cupressi of the northern hemisphere and still more closely represented a genus in South Africa which was then called Callitris and the Pachyleptum of North Africa. He said that about fifteen Australian species were known and that the genus was spread over all parts of the continent. He identified the species he found in Tasmania as Frenela rhomboidea with a habitat in Spring Bay, Oyster Bay and other East Coast locations. Frenela Australis, F. oblonga and Callitris Gunni were abundant on the gravelly banks of the South Esk, where they were known as the native cypress. He dismissed the wood as of little use, although it was said to be obnoxious to bugs from its resinous odour (Hooker, 1860, III pp. 349-52).

The major classificatory work on Australian flora at this time was entrusted to a man with an international reputation as a botanical theorist, 
George Bentham (1863-73). That he had never visited Australia was merely a minor disadvantage outweighed by his access to European professionals and the specimens sent back to Europe. Bentham favoured the idea of the fixity of species, which he never entirely yielded to evolutionary theories. $\mathrm{He}$ had endless problems because he had never seen any of these species growing. Callitris is classified in volume VI under dicotyledon and the order Coniferae CXVT, with eleven genera of which Callitris or Frenela is the sixth (Bentham 1873, vol. VI, pp. 232-39). His extreme caution in describing the male and female organs is partly also due to theoretical botanical disputes about the exact function of the various parts and about the relationship of the gymnosperms to the angiosperms (Jackson 1906, passim). His species nomenclature has been much altered which would have pleased von Mueller who wrote: '... as Australian field work experience is required to recognise the limits of species, I fear ... that very many of Mr Bentham's newly established species will not stand the field test' (Daley 1927 pp. 133-4).

The appended tables show how the species names have changed. Table 1 shows the major shifts, while Table 2 lists just some to the alternative Latin and English names widely used at different times for the same species. However, this gives only a sketch of the difficulties involved. Bentham, for example, lumped together species given separate identities elsewhere. Under robusta, he has glauca and microcarpa, intratropica, columellaris, Moorei, verrucosa, tuberculata and canescans, some of which were later resurrected. Allocating specimens to species has been equally contentious. The Herbarium at Kew and the Natural History Museum have many of the surviving early specimens. The sheets on which they are mounted are covered with notations of reclassification and renumbering as well as with often conflicting 'resolutions' of the classification by experts old and new. For example, one early specimen in the box labelled columellaris at Kew was collected by Alan Cunningham and identified as Callitris robusta from Rottnest Island by Cunningham and Hooker in 1835. Worryingly, this was marked in 1996 by A. Farion as columellaris and not from Rottnest.

Such revisions underlie the attempts of later botanists to explain the idiosyncratic pattem of Australian flora and the divergence of species, in line with Northern interpretations. Observations were accurate enough; explanations remained unsatisfactory. Ellwood Cooper spoke of Callitris as not existing in the north of Australia, and claimed that 'the great mass of purely Australian species and endemic genera must have originated or been differentiated in Australia and never have spread far out of it.' The only exceptions he observed are a few Australian types appearing in the Malayan archipelago and a very few as far as South China: 
No less if not more ancient must be the connection of the mountair: flora of Victoria and Tasmania with the general southem extratropic and mountain region extending through New Zealand to the southe end of the American continent and thence up the Andes (Coop 1878 pp. vi, 194-6).

Little of this Australian analysis penetrated European accounts. The Pinetum by George Gordon in 1880 does no more than mention the species peculiar to Australia-Araucaria, Pbyllocladus, Dammara, Dacrydium and Frenella. He used few of the species names which Bentham had blessed preferring the older names of Brown and others: Verucosa, Gunni, Collemellaris, Frenella Arenosa 'found in sandy places in New Holland called the Oyster Bay pine' and Callitris Cernacosa 'called the Murray pine by settlers' (Gordon 1880; 47-8, 57, 117-, 120-23). The fossil record was looked at by Von Ettingshausen in Tertiary Flora of Australia (1888). He records as Callitris Prisca a fossil from Vegetable Creek, Emmaville, New South Wales in the Tertiary period.

About 1900 Mendel's laws became important in explaining genetic change. There were assumptions that there would be genetic variations within the Callitris species on the general grounds that if a species had a natural distribution within which environmental conditions varied, natural selection would result in genotypes not well adapted to some sites tending to die out. However, the earliest systematic investigations did not find this. Economics drove examination of tree species. Richard T. Baker and Henry G. Smith's $A$ Research on the Pines of Australia, published in 1910, was firmly focussed on the economics of the pine. The authors spent a good deal of space on Callitris because 'next to Eucalyptus of the Myrtaceous order it is probably the most important in Australia having a more extensive geographical distribution than any other genus of Australian conifer' and was 'immune to the ravages of white ants'. They also re-arranged their scientific sequence. They included one or two recently identified species from remoter parts. By this time evolution was the accepted theory and although they did not think they could establish a complete table of origin for the Coniferae they claimed that "when the whole of the genera shall have been investigated on similar lines, a table of origin for the whole family will be evolved'. The authors pointed out that their predecessors had relied mainly on morphology, while they intended to take into account histology, physiology, phylogeny, embryology and chemistry. 'They restored most of Brown and Cunningham's species to specific rank and not the rirtal absence of varietal forms. They also postulated an ancestor a arrangements of the stomata obtained in the leaves of the Lipudode; Hickii of the Carboniferous period and thought there was a similarity it. 
timber of Callitris to those 'figured by Arber from the Nicol collection under Dadoxylon australe of the Palaeozoic period'. They identified a 'considerable break botanically and chemically in the sequence connecting Callitris Macleayana with the other Callitris. This 'stringy bark pine' is 'nearly araucaria.' They could not say which was the older, but said that both were of considerable age on the continent, that evidence of geological age of the genus was not so far away:

what [evidences] there are rather point to an origin probably older than the araucarias ... and we are inclined to think that further palaeontological research will reveal a much older age than that now assigned to the genus.

The twentieth century saw further reclassification of specimens and species as botanical methods changed. The revision of Dallimore's handbook overturned the nomenclature (Dallimore and Jackson, 4th ed.) and Ken Hill in turn has revamped theirs (Hill 1998, pp. 576-88). The number of different names for the individual species reflect the complex historiography of their classification. Just one species Callitris glauca or the Murray river pine, the white pine or white cypress pine, has at different times been named Callitris Huegellii Knight; Frenela canescens Parlatore; Frenela cassivallivis Miquel, Frenela Gulielmi Parlatore.

The new orthodoxy to explain distribution of plant species depends on the belief in plate tectonics with which botany has now been integrated in a rather circular fashion. Wilson Stewart and Gar Rothwell (2nd edition 1993 pp. $4,418,510$ ) claim that on a world-wide scale palaeofloristic studies have provided evidence of plate tectonics and the drifting of continents. Divisions into climatic epochs are made from botanical studies of pollenspalynology - which are then used to help explain botanical changes. Despite detailed palynographic work in some places in Australia, we still seem to lack a unifying explanation for what is and is not to be found in Australia which explains absences, the things that were never in Australia or the things which disappeared, and the ways in which particular species are confined to particular areas. What there is, is very contentious and is not helped by continuing disagreements about the dating, movement and form of the plates on which the continents sit and the identification, age and dating of the fossil record.

So far as Callitris is concerned, until the mid-1970s the hypothesis of Mirov (Mirov 1967), based on Mesozoic fossil flora from the Triassic, Jurassic and Cretaceous locales, was accepted. Mirov believed in a farnorthem circumpolar continent known as Beringaria (which has since been consigned to myth). Since then the dates of the plates, their movements and 
their directions have undergone various re-jigging as has the movemen: the genus. The belief that fossils of existing pine species go back to Triassic has been abandoned. The genus is now thought to have originar in early to middle Mesozoic. about the mid Jurassic period (c.180 millic years ago). Richardson thinks that there is some evidence that Cedrus and possibly Larix appeared before the Tertiary but that other genera of the family appeared only in early Tertiary or later (Richardson 1998, p. 69ff). R.S. Hill says that Jurassic flora were dominated by conifers basically cosmopolitan in aspect but the appearance in relative abundance of Podocappaceae and Araucariaceae is an expression of the generation of a new autochthonous Gondwanaland flora (Hill 1994, pp. 8-9, 143, 289-90, 356-60, 382). Since Alvin, Creber and others have redefined the characteristics of Pinus, and all the fossils from the Triassic and Jurassic and many from the Cretaceous were reclassified mostly into the extinct pinaceous genera, Pityostrobus and Pseudoaraucaria, some of this must presumably be rethought (Millar in Richardson, 1998, ch. 3 at p. 70).

Recent studies of the history of pines in the Quaternary period have led to new interpretations of the impact of palaeohistoric events on the genetic structure and evolutionary relationships of extant species. Richardson says that although the ancestors of Pinaceae had evolved by the mid-Jurassic, Pinus itself evolved only in the low Cretaceous. By the end of the Mesozoic pines had diversified into three major groups and several early subsections, but it is not clear where he sees Callitris fitting into this development. If existing forms of Pinus evolved only in the Low Cretaceous, about c. 100 million years ago, it means that the earliest known fossils of existing Callitris date from after the time Australia and Antarctica were, on current thinking, breaking away from Pangaea in the mid-Jurassic.

How and when did the indigenous pine genera establish their hold on particular areas of Australia in the Tertiary and Quaternary periods? Palaeocene flora contained many lineages of mesic old-world affinities. However and apparently, none of the early tertiary genera of Araucariaceae, Cupressaceae and Taxodiaceae can be distinguished by pollen. The absence of moist mountain habitats is thought to have restricted the entry of taxa such as Abies, Ulnus, Picea and Pinus. Australia is assumed to have generally shared the Northern Hemisphere changes in Tertiary climate and vegetation with the early increase of temperature and humidity continuing into the Eocene (5-7 degrees above the Cretaceous). There were no polar ice caps and the angiosperms adapted to warm humid and equable conditions. About 40 million years ago Antarctica was over the south pole but remained rel 'ively ice free as the warm gyre of the South Pacific helped. Nothofagus don vegetation in Antarctica and perhaps southern Australia as there was 
water, and no cool current glaciation in Antarctica. Species like Acacia were already established. Kemp cites evidence for widespread rainforest in the Eocene epoch. The long cool period between two wet moist periods in a continent increasingly cut off from its land neighbours, however, was probably an important determinant of composition, turnover rates and richness of the flora. Aubrey says that during the mid-Eocene floras the taxa were adapted to areas of seasonally dry climate. In the early Oligocene with cooling, there was extinction of boreotropical taxa in the north where the pines reappeared and recolonised areas where their Mesozoic ancestors had lived. Does this explain the distribution of Callitris in Australia? Linda Graham says mallee Eucalyptus prospered at the expense of taxa such as Callitris. Today, Callitris in the Brigalow bioregion are able to adapt to aridity, and so might have survived these climate changes (Graham 1993, pp. 289, 382, 383).

Despite the increasing isolation of Australia from the mid-Eocene epoch when it broke away from Antarctica c. 30-37 million years ago, moved north and opened up the great southern ocean-which is thought to have significantly affected global temperatures-Australian flora are by no means totally distinct from those elsewhere which creates problems of its own. Only about ten per cent of families represented in Australia can be described as being Gondwanan (having been dispersed across Gondwana before its fragmentation or having originated in the Australian block after parting company with Antarctica without subsequent dispersal having obscured their origins). Callitris belongs to a Northern Hemisphere family but is a genera peculiar to Australia. Most Gymnosperms and Nothofagus in Australia are very much a relict component confined to moist habitats, usually closed forests, and showing relatively little evolutionary modification since the Mesozoic (Veevers 1984), but some species of Callitris are adapted to dry conditions.

How far Australia's isolation led to the production of new variants or species and how far it was a repository of organisms which were once global (families of lizards for example) remains controversial. Twentieth century researchers were more pessimistic than their nineteenth century forbears about the evidence we can assemble about the past. There are more gaps than records and palynology has its limitations. Because of the high production of pollens by pines, the potential of the grains for long distance aerial transport, and their high potential for preservation, it could be overrepresented in the fossil survivals, compared to the number of pines surviving today.

The most recent work on the biogeography of pine and its ecology, edited by David Richardson in 1998, notes that they usually form the 
dominant vegetation where they occur. The preface wonders what trat. equipped pines to be such tenacious persisters and aggressive coloniser Richardson has disappointingly little to say, however, about the Australian pines. One thing that helped pines was their ability to resist frequent fires while fire destroyed broadleaved species which might have competed with them. Although the Eucalypt revives rapidly after fire, this resistance may have helped the Callitris.

It remains a genus which has received less than its due share of research, although it promises one key to some of the continuing mysteries of the floristic particularities of Australia and to a better understanding of the symbiosis of soil, climate and plants.

\section{References}

Baker, Richard T. and Smith, Henry G. 1910. A Research on the Pines of Australia. Sydney: NSW Govt. Printer.

Bentham, George 1863-73. Flora Australiensis. 6 vols, London: L. Reeve.

Brown, Robert 1810. Prodromus Florae Novae Hollandiae. London: R. Taylor.

Cooper, Ellwood 1878. Fonest culture and eucalyptus trees. San Francisco: Cubery \& Co.

Daley, Charles 1927. The bistory of Flora Australiensis from the correspondence of Sir William Hooker, George Bentham and Sir Joseph Hooker with additional letters to Baron von Mueller from Sir Joseph D. Hooker. Melboume: Reprinted from the Victorian Naturalist.

Dallimore, W. (with help from Jackson, A.B). 4th ed. 1966. Handbook of Coniferae and Ginkgaaceae. London: E. Amold.

Garden, J. 1957. A revision of the genus Callitris. Contributions NSW Natural Herbarium 2: 363-92.

Gordon, George 1880. The Pinetum. London.

Graham, Linda E. 1993. Origins of Land Plants. New York: Wiley.

Hill, Ken 1998. Callitris. In Flora of Australia 48, pp. 576-88.

Hill, Robert S. (ed) 1994. History of the Australian vegetation: Cretaceous to Recent. Cambridge University Press.

Hooker, J.D. 1860. Flora Tasmaniae III(i) as surgeon of the Erebus and botanist

Jackson, B.D. 1906. George Bentham. London.

Mirov, Nicholas Titus 1967. The genus Pinus. New York: Ronald Press.

Richardson, David M. (ed.) 1998. Ecology and biogeograpby of Pinus. Cambridge University Press.

Stewart, Wilson and Rothwell, Gar. H. 2nd ed. 1993. Paleobotany and the evolution of plants. Cambridge University Press.

Veevers, J.J. 1984. Phanerozoic Earth History of Australia. Oxford University Press (Oxford Monographs on Geology and Geophysics no 2).

Ventenat, E.P 1808. Decas Generum Novoru aut parum cognitorum auctore E.P.Ventenat, Paris, no 10.

Von Ettingshausen, C.F. 1888. Contributions to the Tertiary Flora of Australia. Sydney: Dept. of Mines. 


\section{Appendix: Callitris species names}

Table 1. Major pattern of naming, 1867-1998

\begin{tabular}{|c|c|c|c|c|}
\hline $\begin{array}{l}\text { Bentham } \\
1867\end{array}$ & $\begin{array}{l}\text { Gordon } \\
1880\end{array}$ & $\begin{array}{l}\text { Baker and Smith } \\
1910\end{array}$ & $\begin{array}{l}\text { Dallimore and } \\
\text { Jackson } 1966\end{array}$ & $\begin{array}{l}\text { Hill } \\
1998\end{array}$ \\
\hline \multicolumn{5}{|l|}{ Australis [9] } \\
\hline Drummondi [4] & & Drummondii [12] & Drummondii & drummondii \\
\hline Endlicheri [8] & & & & endlicheri \\
\hline Macleayana [2] & Macleayana & Macleayana [17] & Macleayana & madleayana \\
\hline Muelleri [6] & & Muelleri [15] & Muelleri & muelleri \\
\hline \multicolumn{5}{|l|}{ Parlatorei $[1]$} \\
\hline Rhomboida [7] & & Rhomboida [10] & & rhomboidea \\
\hline Robusta [5] & & Robusta [1] & Robusta & \\
\hline \multirow[t]{18}{*}{ Roei [3] } & & Roei [13] (rare) & Roei (Endlicher) & reei \\
\hline & Arenosa & Arenosa [6] & & \\
\hline & Canescens & & & canescens \\
\hline & Columellaris & & & columellaris \\
\hline & Gunni & & & \\
\hline & Macrostachya & & & \\
\hline & Verrucosa & verrucosa $[3]$ & Verrucosa & verrucosa \\
\hline & & $C S p$ Novis $[18]$ & & \\
\hline & & calcarata $[9]$ & & \\
\hline & & glauca $[5]$ & glausa & glaucophylla \\
\hline & & gracilis $[8]$ & gracilis & gracilis \\
\hline & & intratropica $[7]$ & intratropica & intratropica \\
\hline & & Morrisoni [14] & Morrisoni & \\
\hline & & oblongata [16] & oblongata & oblonga \\
\hline & & Propinqua [4] & Propinqua & \\
\hline & & Tasmanica [11] & Tasmanica & \\
\hline & & tuberrulata $[2]$ & tuberculata & tuberrulata \\
\hline & & & neocaledonica & \\
\hline
\end{tabular}

baileyi

monticala

preissii

Note: The figures in [] show the order given by Bentham and by Baker and Smith. 
Table 2a: Variations in species names in Dallimore and Jackson (1966)

\begin{tabular}{|c|c|c|c|}
\hline & Originator & Other name & Location \\
\hline Drummondii & $\begin{array}{l}\text { Bentham with } \\
\text { Hooker }\end{array}$ & Cypress pine species & Coast W Australia \\
\hline Glauca & R. Brown & $\begin{array}{l}\text { canescans, crassivalivis; } \\
\text { bugelii; white pine; } \\
\text { Murray pine, } \\
\text { columellaris var, } \\
\text { campestris }\end{array}$ & Widespread inland \\
\hline $\begin{array}{l}\text { gracilis (two } \\
\text { subspecies, } \\
\text { hybridises } \\
\text { gracilis and } \\
\text { murrayensis) }\end{array}$ & R.T.Baker & $\begin{array}{l}\text { Mountain cypress pine } \\
\text { originally discovered } \\
1893 ; \text { Frenella gullielmi, } \\
\text { parlatore } 1868\end{array}$ & $\begin{array}{l}\text { Tal, Tal Gowie Bylong, } \\
\text { Rylstone }\end{array}$ \\
\hline Intratropica & $\begin{array}{l}\text { Bentham and } \\
\text { Hooker }\end{array}$ & $\begin{array}{l}\text { Variation of robusta; } \\
\text { microcarpa }\end{array}$ & $\begin{array}{l}\text { Northern NT and NW } \\
\text { coast WA }\end{array}$ \\
\hline Macleayana & $\begin{array}{l}\text { Bentham and } \\
\text { Hooker }\end{array}$ & $\begin{array}{l}\text { parlatorei; octoclinis; } \\
\text { stringybark; Port } \\
\text { Macquarie pine }\end{array}$ & $\begin{array}{l}\text { E Coast north of } \\
\text { Newcastle to Qld, } \\
\text { Atherton Tableland, } \\
\text { Dorrigo State Forest. } \\
\text { Moderately common in } \\
\text { rainforest }\end{array}$ \\
\hline Morrisoni* & R.T. Baker & $\begin{array}{l}\text { Morrisons cypress pine } \\
\text { First discovered } 1903\end{array}$ & SW Australia \\
\hline Muelleri & $\begin{array}{l}\text { Bentham and } \\
\text { Hooker }\end{array}$ & $\begin{array}{l}\text { Fruticosa; Parlatori, } \\
\text { Illawarra pine }\end{array}$ & $\begin{array}{l}\text { Rare. NSW, Blue } \\
\text { Mountains }\end{array}$ \\
\hline Neocaledonica & Dummer & collected by Schlecter & $\begin{array}{l}\text { New Calendonia at } \\
3000 \text { feet and over }\end{array}$ \\
\hline oblonga & Richard (Tas) & $\begin{array}{l}\text { Gunni, Australis. } \\
\text { variabilis, macrostachya } \\
\text { native cypress }\end{array}$ & Tasmania, River Esk \\
\hline propinqua* & R. Brown & Moorei & $\begin{array}{l}\text { Rare. Kangaroo Island } \\
\text { and SE NSW }\end{array}$ \\
\hline robusta* & R.. Brown & $\begin{array}{l}\text { Common cypress pine, } \\
\text { black pine; dark pine, } \\
\text { Lachlan pine, light } \\
\text { pine, white pine; } C \text {. } \\
\text { Preissii, C. Suissii, } \\
\text { Widdringtonia } \\
\text { equisetiformis }\end{array}$ & $\begin{array}{l}\text { Widely distributed in } \\
\text { WA }\end{array}$ \\
\hline Roei & Endlicher & Subcordata & Rare. WA \\
\hline
\end{tabular}


Table 2a (Cont.)

\begin{tabular}{llll}
\hline & Originator & Other name & Location \\
\hline sulcata* & Schlecter & balansae & $\begin{array}{l}\text { Comboui valley New } \\
\text { Caledonia up to 1,000, }\end{array}$ \\
\hline Tasmanica* & $\begin{array}{l}\text { Baker and } \\
\text { Smith }\end{array}$ & $\begin{array}{l}\text { arenosa, Oyster Bay } \\
\text { pine }\end{array}$ & $\begin{array}{l}\text { Victoria, NSW, Qld, } \\
\text { Stradbrook Island, Tas. }\end{array}$ \\
\hline tuberculata & R. Brown & $\begin{array}{l}\text { Bentham synonym } \\
\text { robusta }\end{array}$ & $\begin{array}{l}\text { Rare; Middle Island, } \\
\text { York Island Bay }\end{array}$ \\
\hline verrucosa & R. Brown; A & $\begin{array}{l}\text { Turpentine pine; } \\
\text { camphor wood; smithy } \\
\text { Cunningham } \\
\text { ex Endlicher }\end{array}$ & $\begin{array}{l}\text { Red desert sandhills; } \\
\text { Dry NSW and WA; } \\
\text { Brachs pine. Gordon } \\
\text { hays Murray pine, } \\
\text { subspecies of preissi }\end{array}$ \\
& & & \\
& &
\end{tabular}

Note: * means not in Hill

Table 2b: Variations in species names in Hill (1998)

\begin{tabular}{|c|c|c|c|}
\hline & Originator & Other name & Location \\
\hline baileyi & C.T. White & Found 1903 & $\begin{array}{l}\text { Rare. NE Darling } \\
\text { Downs and tablelands } \\
\text { NE NSW }\end{array}$ \\
\hline canescens & Parlatore & morrisoni & Interior WA \\
\hline columellaris & $\begin{array}{l}\text { Mueller, } \\
\text { Parlatore }\end{array}$ & $\begin{array}{l}\text { Moorei, arenosa nom } \\
\text { illeg. }\end{array}$ & $\begin{array}{l}\text { Deep coastal sands } \\
\text { Clarence river to } \\
\text { Maryborough }\end{array}$ \\
\hline endlicheri & F.M. Bailey & $\begin{array}{l}\text { australis, calcarata nom } \\
\text { illeg. }\end{array}$ & $\begin{array}{l}\text { Tablelands W slopes } \\
\text { NSW Vic. }\end{array}$ \\
\hline marticola & J. Garden & & $\begin{array}{l}\text { Rare. Shrub. N coast } \\
\text { and Northem tablelands } \\
\text { of NSW and Qld border }\end{array}$ \\
\hline preissi & Miq; L Preiss & mobusta & $\begin{array}{l}\text { Rottnest Island, } \\
\text { restricted to small areas } \\
\text { around Perth }\end{array}$ \\
\hline rhomboidea & R. Brown & $\begin{array}{l}\text { Frenela triquetra, } C . \\
\text { australis, gunni var } \\
\text { mucronata, and var } \\
\text { tasmanica, Port Jackson } \\
\text { pine, Oyster Bay pine }\end{array}$ & NSW coastal regions \\
\hline
\end{tabular}




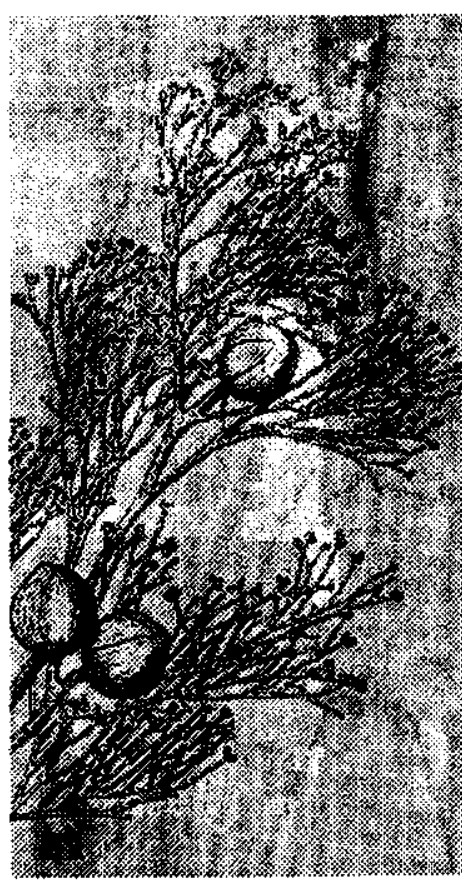

3

\title{
A history of the wood anatomy of Callitris
}

\author{
Roger Heady
}

\section{Introduction}

Ninety years have passed since Baker and Smith (1910) made the first comprehensive description of the wood anatomy of Callitris. Since that time, microscopic imaging technology has improved, enabling us to see wood structure at higher magnification and in greater detail than has ever before been possible. As a result, our understanding of the role of particular wood structures in the functioning of the tree has been enhanced and two features of the Callitris wood anatomy which were not included in Baker and Smith's original findings have been discovered.

In this chapter, five major features of the wood anatomy of Callitris are shown in images formed by scanning electron microscopy: tracheids, bordered pits, callitroid thickening, rays and warty layer. The images make visible the structure of the wood with high resolution over a wide range of magnifications and by reference to them the functional purpose of each wood feature is suggested. Scanning electron microscope images are then used to provide a clearer understanding of the history of the wood anatomy of Callitris by using them to complement some of the hand-drawn sketches and light microscopy photographs which have been published over the past century in various books and scientific journals. 


\section{Tracheids}

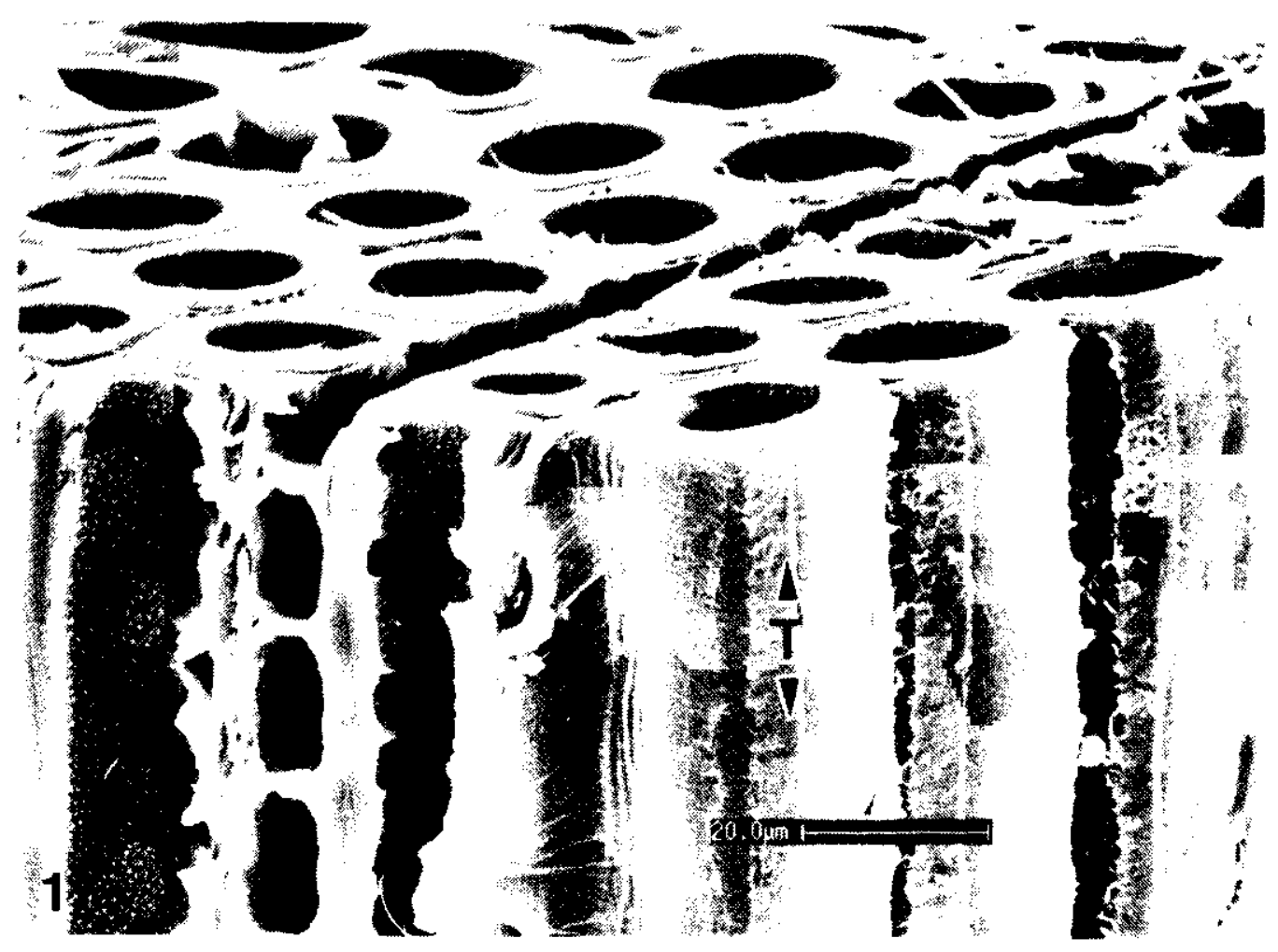

Figure 1. Scanning electron microscope image of the corner of a block of wood of Callitris glaucophylla showing tubular tracheids aligned vertically (one of which is marked " $\mathrm{T}$ "). The scale bar indicates $20 \mu \mathrm{m}$ (i.e. $1 / 50$ $\mathrm{mm})$, magnification $=900 \times$

Tracheids make up approximately 90 percent of the volume of the wood of Callitris. They consist of tubular structures (Figure 1) about one fiftieth of a millimetre in diameter which, in the tree, are aligned axially to the trunk. Their prime function is to conduct water from the roots up to the leaves. The first illustration of tracheids in Callitris was that of Baker and Smith (1910). Subsequent images can be found in Patton (1927), Greguss (1955, 1972), Davies and Ingle (1966), and Heady (1997).

Tracheid diameter varies seasonally, and these differences form concentric 'growth rings' in the trunk of the tree (Figure 2) which, to the naked eye, are 'sometimes distinct, other times indefinite in Callitris' (Dadswell and Eckersley 1935). Figure 3 is a reproduction of a photograph published by Baker and Smith (1910) of a transverse section (end-on view) of tracheids in Callitris glaucopbylla showing the variation in tracheid cavity diameter 'at junction of spring and autumnal tracheids'. 


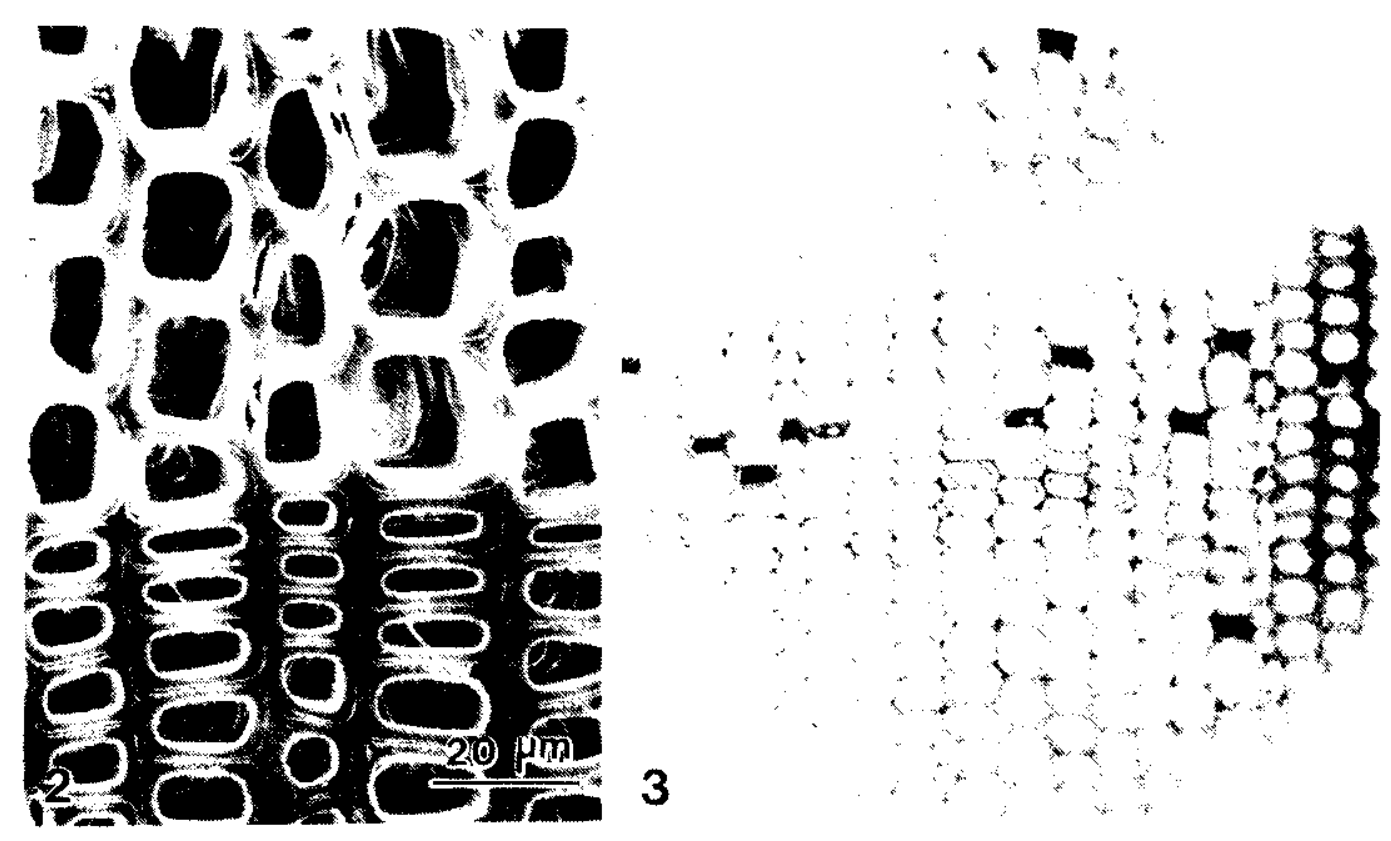

Figure 2. Scanning electron microscope image of a block of wood of Callitris glaucophylla viewed in transverse section showing the abrupt change in tracheid diameter relating to slow (autumn/ winter) growth in lower half of image and fast (spring/summer) growth in upper half of image.

Figure 3. Photograph reproduced from page 139 of Baker and Smith (1910). The original caption states: 'Transverse section of timber at junction of spring and autumnal tracheids. Callitris glauca $\times 80^{\prime}$.

\section{Bordered pits}

Bordered pits interconnect the water column in any particular tracheid with the water columns of neighbouring tracheids. The reason for the interconnection is one of safety for the tree. If tracheids were very long, extending all the way from the roots to the leaves and one tracheid became blocked by an air bubble and stopped conducting water, then that would be a serious matter for the tree, having lost a complete water conducting pathway. It would be much less of a problem if all tracheids were very short but were connected to each other through small apertures in their side walls and for each aperture to have a valve which permanently sealed the aperture if the tracheid should dry out. In Callitris, as in all conifers, water in the trunk rises through a system of thousands of short tracheids, each only a fas inillimetres long but all connected together by bordered pits. Pairs of pits in adjacent tracheids have a shared central membrane (Figurc 
portion (Figure 5) if the water column inside one of the tracheids is lost, thus isolating the dry tracheid from the other (conducting) tracheid and hence all other tracheids in the system. As a result, the tree has lost only one short water pathway in a whole system of interconnected paths. That is far less serious than it would be if it lost one complete water column stretching up the whole height of the tree.

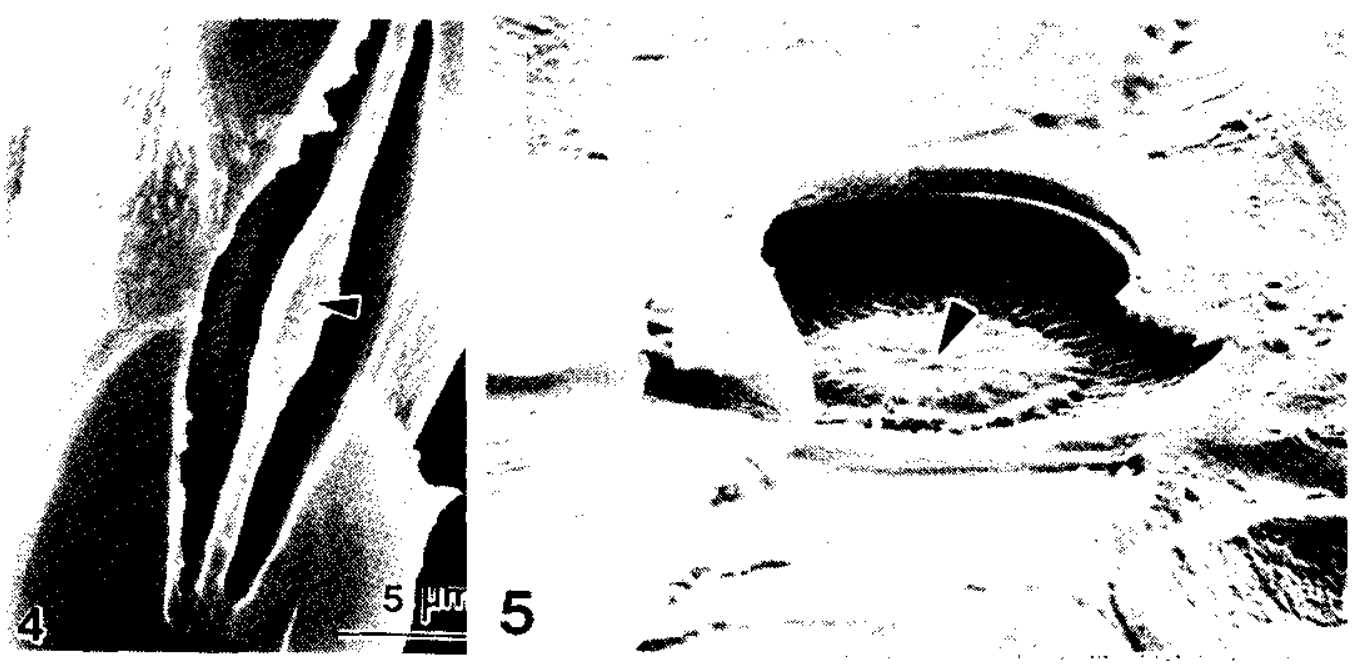

Figure 4. Scanning electron microscope image of a bordered pit pair viewed from the side showing the apertures of pits in both tracheids, shared central membrane and central impermeable portion (arrowed). Magnification $=3000 \times$.

Figure 5. Scanning electron microscope image of a bordered pit viewed from above at magnification $2600 \times$. Part of the raised border around the aperture has been cut away to expose the inner membrane with its central impermeable portion (arrowed).

The presence of bordered pits in tracheids of Callitris was first documented by Baker and Smith (1910). Their photograph of numerous pits in a radial longitudinal section (side view) of tracheids in Callitris intratropica is reproduced in Figure 6. Other images and drawings of bordered pits in Callitris are those of Greguss $(1955,1972)$, Cronshaw (1961), Venning (1979) and Heady (1997).

\section{Callitroid thickening}

Callitroid thickening consists of raised bars of tissue above and below bordered pit apertures (Figure 7). It is almost exclusive to the genus Callitris. The presence of such bars is therefore a definitive taxonomic indicator and 
the use of callitroid thickening as a feature separating Callitris from oth genera has been well established in taxonomic keys for a number of $\mathrm{d}$ cad (Phillips 1948; Greguss 1955; Barefoot and Hankins 1982; Wheelet et I. 1985).
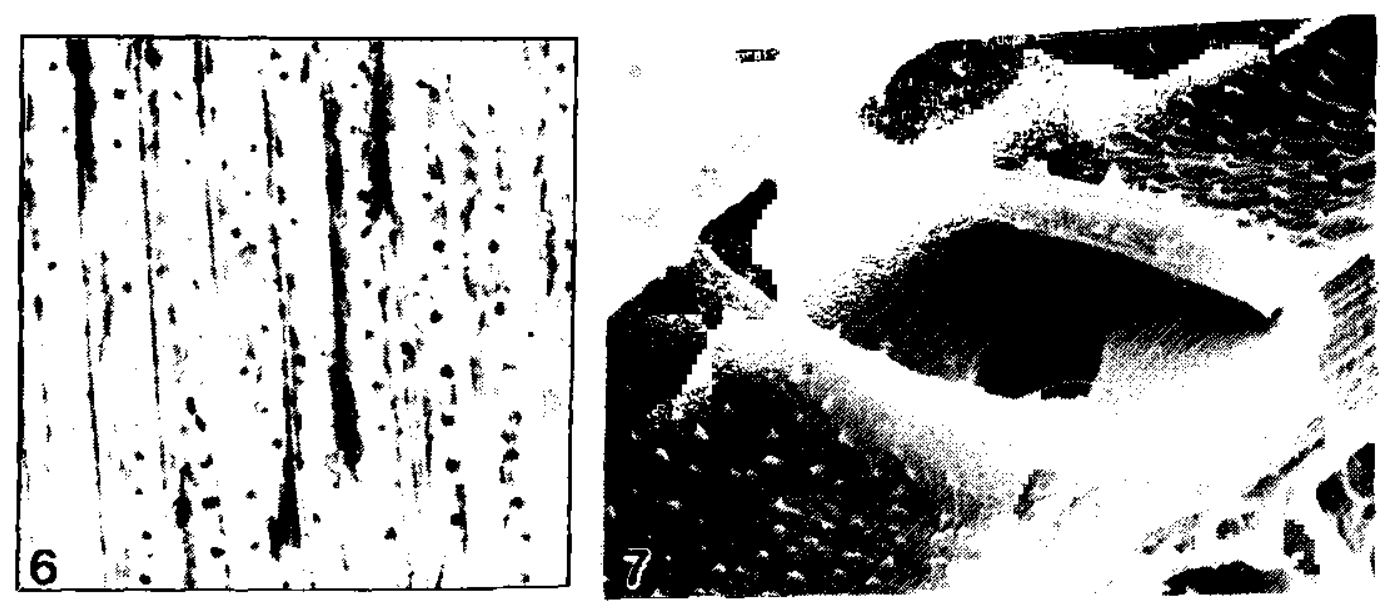

Figure 6. Photograph adapted from page 178 of Baker and Smith (1910) and which has the caption: Radial section through the timber showing the bordered pits of the tracheids. Callitris intratropica $\times 120$ '.

Figure 7. Scanning electron microscope image at magnification $2800 \times$ of a single bordered pit with associated callitroid thickening. The thickening bars have been cut through to expose them in sectional view.

The purpose of callitroid thickening is still a matter of conjecture but Heady and Evans (2000) have suggested that a bordered pit aperture represents a weakness in the tracheid wall and is therefore the point at which cell wall collapse is most likely to occur in times of water stress. In this respect, the bars of callitroid thickening act as reinforcement structures on either side of the aperture to lessen the likelihood of wall collapse in that area.

Historically, the first account of callitroid thickening in the literature was by Kleeberg (1885) who reported (in German): 'kleine borizontale leistchen' (small horizontal ledges) at the tops and bottoms of pits in wood of Frenela (Frenela is an early synonym of Callitris). Twenty-five years later, Baker and Smith (1910) failed to recognise callitroid thickening as an anatomical feature of Callitris wood even though it is vaguely apparent in several of their photographic plates. Patton (1927) used a hand-drawn sketch (Figure 8) to describe what he termed 'rectangular plates of thickeni :.'. The sketches of Budkevitch (1936) and Peirce (1937) are similar to that of Patton (1927). In the softwood key of Phillips (1948) a light mi - scony 
photograph of callitroid thickening is used to describe this feature and this is reproduced in Figure 9.
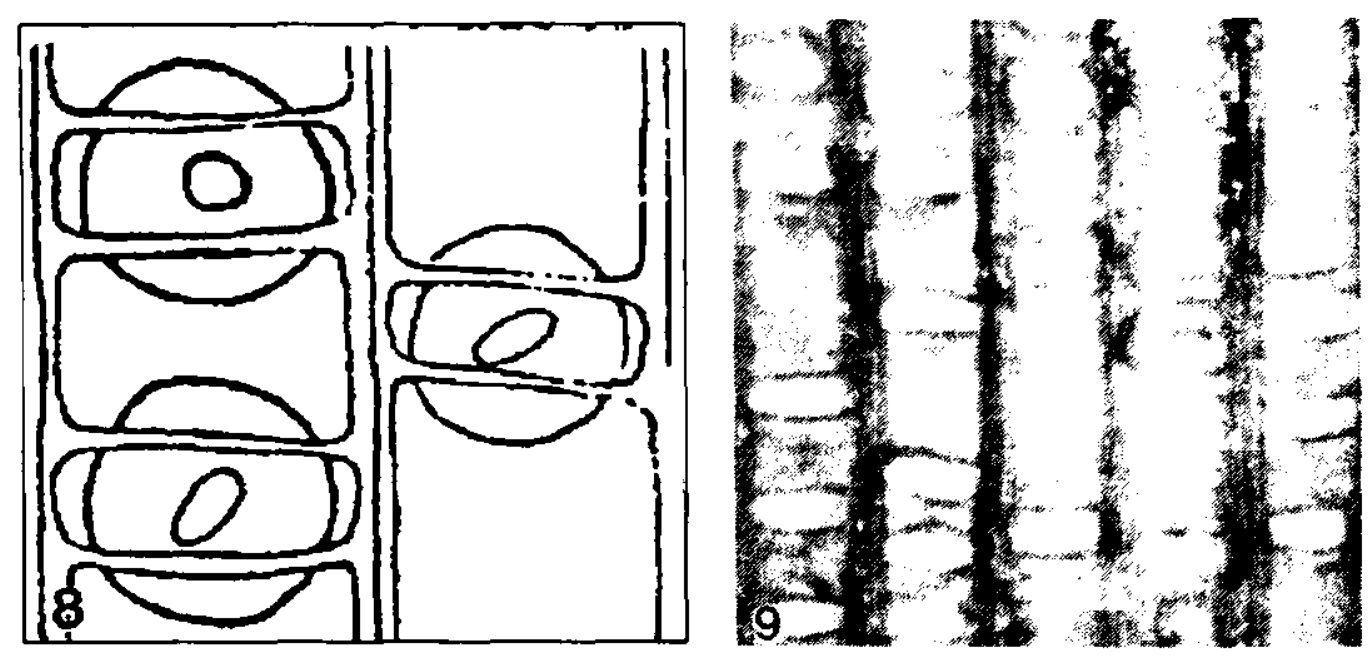

Figure 8. Drawing reproduced from Patton (1927). The original description is as follows: 'Each bordered pit is associated with a more or less rectangular plate of thickening, extending across the tracheid, beyond the margins of the pit, but not reaching to the upper or lower margin'.

Figure 9. Photograph reproduced from Phillips (1948) which has the caption: 'Callitris glauca. RLS $\times 175$. Tracheids with thickenings across the pit borders'.

Greguss (1955) refers to callitroid thickening as 'bars of Kleeburg', in apparent acknowledgment of the first description of this feature by Kleeberg (1885). More recently, images of callitroid thickening occur in Cronshaw (1961), Jane (1970); Butterfield and Meylan (1980), and Heady and Evans (2000). Patton (1927), Budkevich (1936), Phillips (1948), and Greguss (1955) reported that callitroid thickening was absent from Callitris oblonga and Callitris macleayana. However, Heady and Evans (2000) recently showed that callitroid thickening occurs in both of these species but the frequency of its occurrence on bordered pits is so low that its presence may be missed unless hundreds of pits are examined.

\section{Rays}

The rays of Callitris wood consist of thin bands of cells (Figure 10) which are aligned radially to the tree trunk. They make up approximately 8 percent of the volume of the wood of Callitris (Heady 1997). Rays provide 
transverse pathways for the flow of sap and nutrients and also function in the storage of reserve carbohydrates (Greguss 1955).
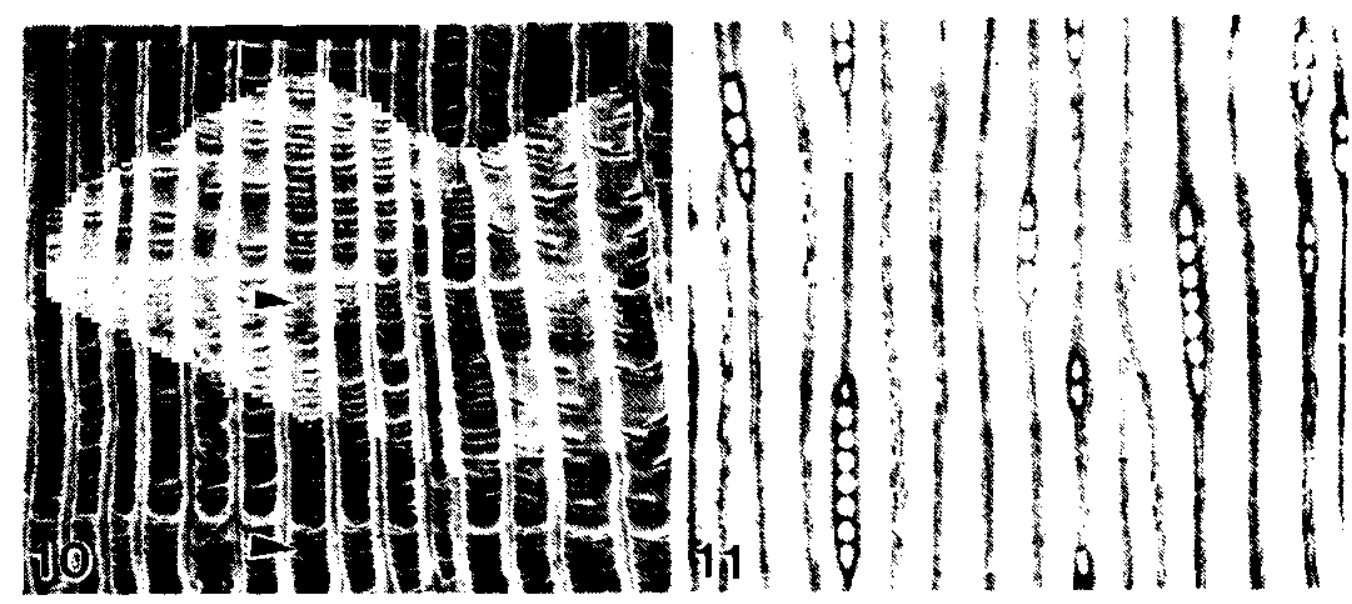

Figure 10. Radial longitudinal section inclined at $50^{\circ}$, showing two rays (arrowed) aligned horizontally. Callitris glaucophylla. This scanning electron microscope image is from Heady (1997). Magnification = $140 \times$.

Figure 11. Photograph adapted from page 96 of Baker and Smith (1910) and which has the caption: Tangential section through timber of Callitris robusta $\times 160$ '. The ray in the lower left of the image consists of eight vertically-aligned cells.

Illustrations of rays in Callitris can be found in Baker and Smith (1910), Patton (1927), Greguss (1955; 1972), and Heady (1997). The most commonly-used descriptive parameter for ray morphology is 'ray height' i.e. the number of cells from the top to the bottom of the ray (Figure 11). Peirce (1937) and Wheeler et al. (1985) suggested that ray heights in Callitris were 'exceptionally tall' in relation to those of other conifers. However those reports have since been shown to be incorrect (Heady 1997).

\section{Warty layer}

A warty layer lines the inner walls of tracheids of most conifer genera, including Callitris (Figures 12 and 13). Individual warts of the layer are very small, typically less than one micron (one thousandth of a millimetre) in height (Figure 14) and are therefore unable to be detected by light microscopy. This accounts for why this wood anatomy feature was unknown prior to the advent of electron microscopy in the $1950 \mathrm{~s}$. 


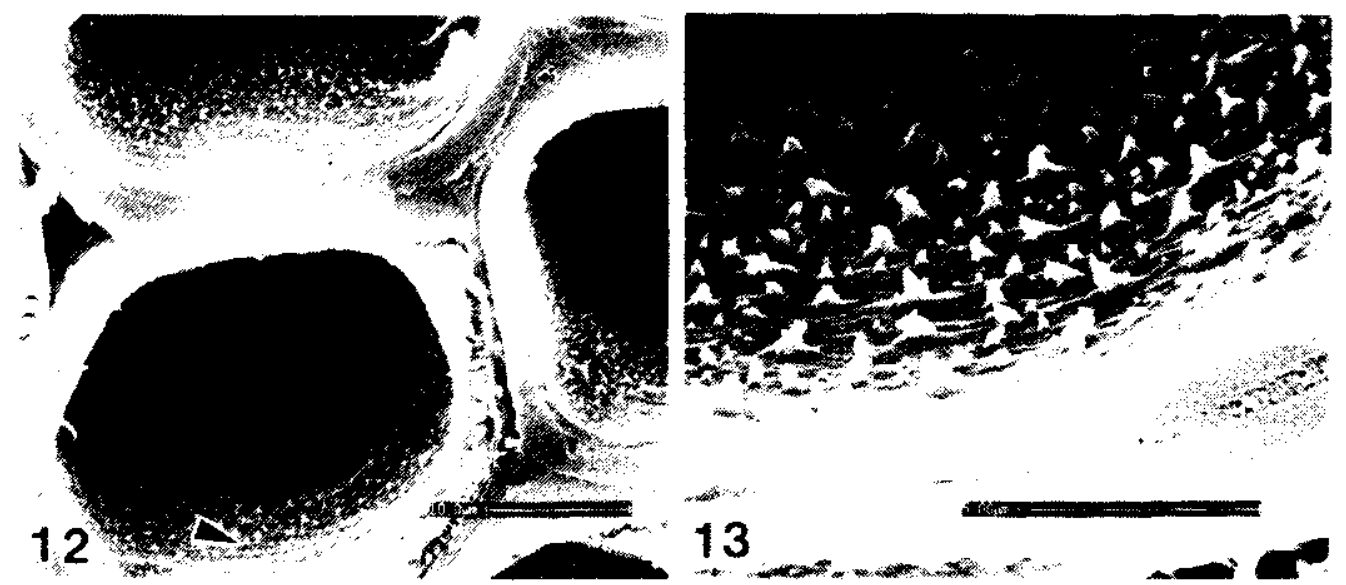

Figure 12. Scanning electron microscope image of tracheids of Callitris glaucophylla showing the warty layer (arrowed) lining the inner walls. Magnification $=1300 \times$.

Figure 13. Scanning electron microscope view of warty layer in cut end of a tracheid. Magnification $=4400 \times$.

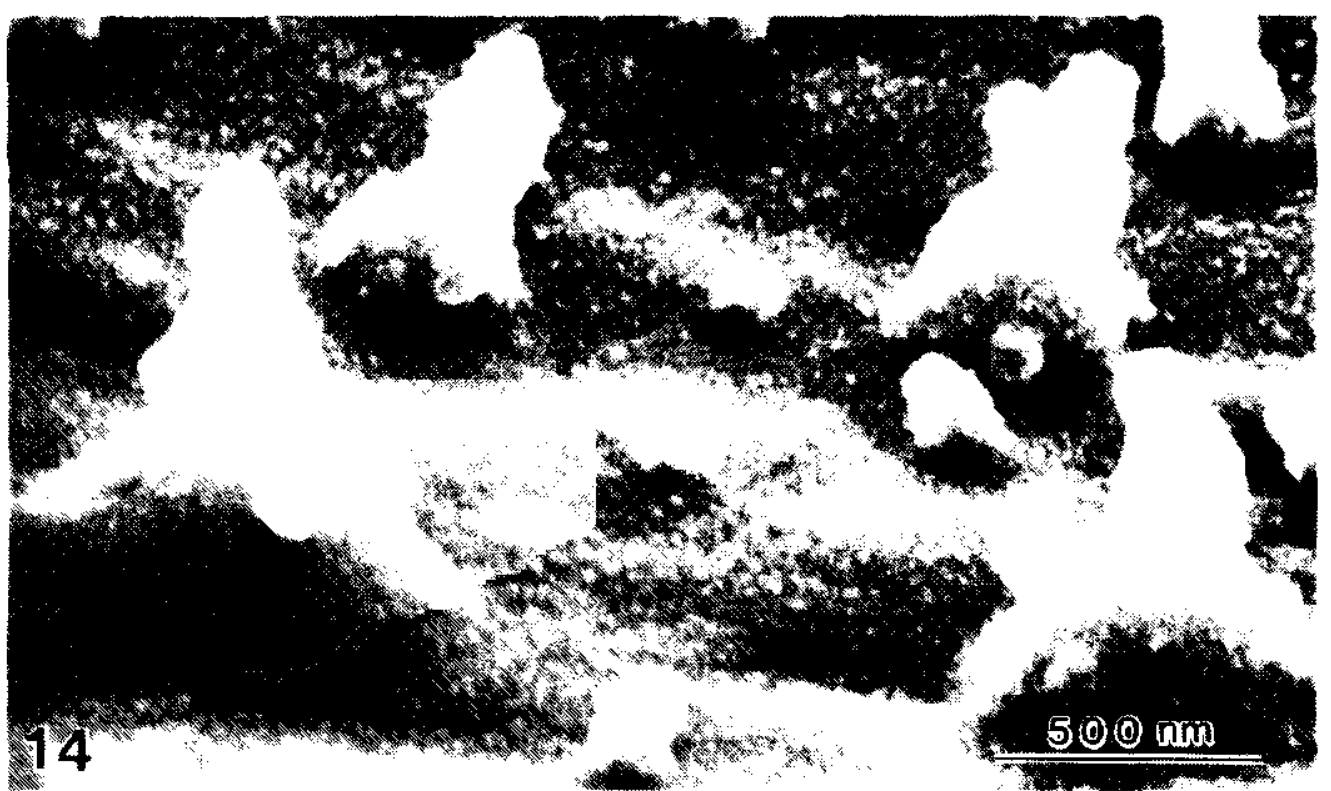

Figure 14. Scanning electron microscope image from Heady et al. (1994) showing the warty layer of Callitris canescens at magnification $50000 \times$. Individual warts are less than one thousandth of a millimetre in height.

The relevance of the warty layer in the functioning of wood is still uncertain. Heady et al. (1994) suggested that warts effectively increase the surface area of the inner tracheid wall and are thereby useful in maintaining a water column within the tracheid when water is in short supply. Their 
suggestion was based on the observation that individual warts of dry-h:? itat species of Callitris tend to be much bigger than those of wet-habitat $C_{u}$ lititis species.

Some of the earliest observations of the warty layer of conifers ware carried out on Callitris because the relatively large size of warts in Callitris compared with those in other genera enabled the structure of the warty layer to be more easily discerned and described. Thus Liese (1957), Wardrop et al. (1959), and Liese (1965) took advantage of the 'numerous bigger warts' in Callitris in their descriptions. More recently, images of the Callitris warty layer have been published by Butterfield and Meylan (1980), and Heady et al. (1994).

\section{Concluding remarks}

These five wood anatomy features are repeated in every cubic millimetre of the wood of every cypress pine tree in the Pilliga Forest and beyond. Our present comprehension of their form, variability and function is a result of advances in microscopy technology and the efforts of the above-mentioned researchers over the past ninety years.

\section{References:}

Baker, R.T. and Smith. H.G. 1910. A research on the pines of Australia. W. Gullick, NSW Govt. Printer.

Barefoot, A.C. and Hankins. F.W. 1982. Identification of modern and tertiary woods. Oxford: Clarendon Press.

Budkevich, E.V. 1936. Some peculiarities in the sculpturing of the tracheid walls of the genus Callitris (in Russian). Sovetskaya Botanika. 4: 130-35.

Butterfield, B.G. and Meylan. B.A. 1980. Three-dimensional structure of wood. London: Chapman and Hall.

Cronshaw. J. 1961. The Nature of Callitroid Thickenings. Joumal of the Institute of Wood Science 8: 12-13.

Dadswell, H.E. and Eckersley. A.M. 1935. The identification of the principal commercial Australian yimbers other than Eusalypts. Melboume: Govt. Printer (CSIR Division of Forest Products, Technical Paper 16).

Davies, G.W. and Ingle. H.D. 1966. Wall thickening in Callitris glauca R. Br. Nature. 209(5025): 826-27.

Greguss, P. 1955. Identification of living gymnosperms on the basis of xylotomy. Budapest: Akadémiai Kiadó.

Greguss, P. 1972. Xylotomy of the living conifers. Budapest. Akadémiai Kiadó.

Heady, RD. 1997. The wood anatomy of Callitris Vent. (Cupressaceae): an SEM study. Unpubl. Ph.D Thesis. The Australian National University. Canberra. 
Heady, R.D., Cunningham, R.B. Donnelly, C.F. and Evans, P.D. 1994. Morphology of warts in the tracheids of cypress pine (Callitris Vent.). LAW A Joumal. 15(3): 265-81.

Heady, R.D., and Evans. P.D. 2000. Callitroid (Callitrisoid) Thickening in Callitris. $L A W A$ Joumal. 21(3): 293-319.

Jane, F.W. 1970. The structure of wood. London: A. and C. Black (2nd. ed).

Kleeberg, A. 1885. Die Markstrahlen der Coniferen. Botanische Zeitung 43(43-46): 673-86, 689-97, 705-14, 721-9.

Liese, W. 1957. Beitrag zur Warzenstruktur der Koniferentracheiden unter besonderer Berücksichtigung der Cupressaceae. Ber. Deut. Botan. Ges. 70(1): 21-30.

Liese, W. 1965. The warty layer. In W.A. Côté (ed.), Cellular ultrastructure of woody plants. 25167. New York: Syracuse University Press.

Patton, R.T. 1927. Anatomy of Australian coniferous timbers. Proceedings of the Royal Society of Victoria. 40(1): 2-16.

Peirce, A.S. 1937. Systematic anatomy of the woods of the Cupressaceae. Tropical Woods. 49: 5-21.

Phillips, E. 1948. Identification of softwoods. London: HMSO (Forest Products Research Bulletin No. 22).

Venning, J. 1979. Character variation in Australian species of Callitris Vent. (Cupressaceae). Unpubl. Ph.D Thesis. University of Adelaide. South Australia.

Wardrop, A., Liese W. and Davies. G.W. 1959. The nature of the wart structure in conifer tracheids. Holfforschung. 13(4): 115-20.

Wheeler, E.A., Pearson, RG., LaPasha, C.A., Zack, T. and Hatley, W. 1985. Computer-aided wood identification. North Carolina Agricultural Research Service (Bulletin 474). 


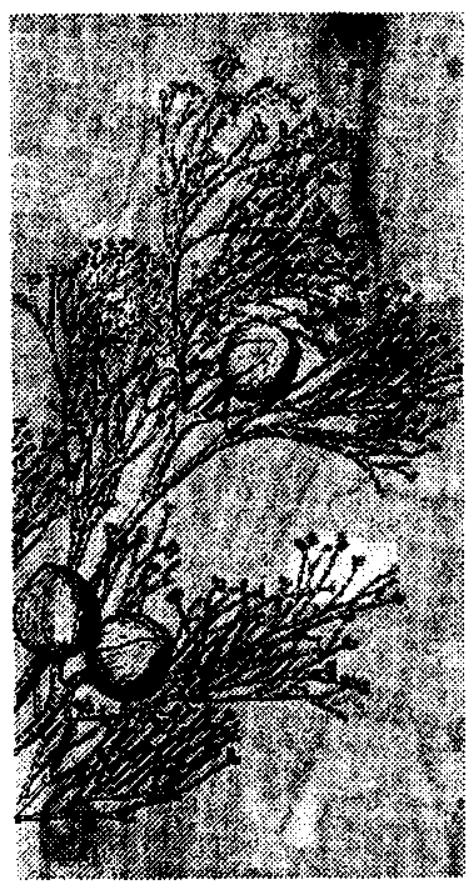

4

Dendrochronology of Australian cypress pines

\author{
John Banks \\ and Ian Pulsford
}

\title{
Introduction
}

Dendrochronology is a useful tool for determining tree ages and investigating the history of a tree's response to past environments such as droughts, fires or to ecological changes. It can provide information for understanding stand dynamics, mensuration data for stand management and for archaeological studies. Tree-ring identification is often arduous and slow as some species are apt to produce false and missing rings, so that perhaps it is for this reason that tree-ring studies in Callitris have been both limited and fragmentary. To date only six of the 17 species have been studied (Lange 1965, Pearman 1971, La Marche et al. 1979, Hammer 1981, Ash 1983, Perlinski 1986, Pulsford 1991, Pulsford et al. 1992 and 1993, Bowman and Panton 1993, Bryant, National Parks and Wildlife Service, pers. comm. 2000). This paper reviews the potential of species of Callitris for dendrochronology and offers avenues for further investigation.

\section{Genus Callitris (Cupressaceae)}

The genus Callitris Ventenat belongs to the Southern Hemisphere subfamily Callitroideae $(\mathrm{Li}, 1953)$ which has related genera in the western Pacific region (2), Africa (2) and South America (3). All these extant genera very 
probably arose from parental stock in the Tertiary following the break up of Gondwana (Datta 1971). Several are long-lived species and have already provided tree-ring chronologies for the reconstruction of paleoclimates (Anon, 2000, Roig 2000). Callitris is by far the largest and most widespread of the Australian conifer genera, with related genera Actinostrobus and Diselma containing only three localised species. It is essentially an Australian genus with 15 endemic species and two more which occur in New Caledonia. The first comprehensive investigation into the genus Callitris (Baker \& Smith 1910) raised early taxonomic complexities and provided ecological data and anatomical details with only passing reference to tree-ring development in the genus. The currently accepted taxonomic status of the species of Australian cypress pine was resolved in 1998 (Hill 1998) by splitting C. columellaris back into the three components recognised by Baker and Smith (C. columellaris, C. glaucophylla and C. intratropica) and recognising one new Western Australian species, $C$. tuberculata. The species list is given in Table 1.

\section{Potential for tree-ring studies in Callitris}

Callitris species are widely distributed across Australia including Tasmania, providing the opportunity to develop a continental network of site indices for the genus. To date dendrochronological studies have been made for six of the 15 species. These have shown the ease of annual tree-ring recognition varies between the species with those growing under strongly seasonal climates producing distinct rings from which chronologies can be derived, e.g. C. intrapropica in the monsoon zone, $C$. preissii growing under a strong Mediterranean-type climate and others growing on sites favourable to producing an annual ring. Species growing under varying climates, typically those with cool winter temperatures and hot dry summers, possess a high frequency of multiple and missing rings. Moreover tree-ring data to date suggests that trees of Callitris are relatively short-lived with maximum ages of only 100 years (Ogden 1978) although older trees have been reported (Hammer 1981) and up to about 160 years by the authors. Intra-seasonal rings make accurate dating difficult if not impossible and coupled with the short-lived trees largely negates much of the potential for using Callitris treering data as a surrogate for pre-European climate variables. However, this type of tree-ring data can produce approximate tree ages and dates by providing an upper and lower estimate of tree age and growth rates and patterns that can be useful for forest stand management and ecological studies (Lange 1965, Pearman 1971). 
Table 1. The Australian Callitris species, habitat type and distribution by - tate and rainfall zone

\begin{tabular}{|c|c|c|}
\hline Callitris species and authority & Habitat type & $\begin{array}{l}\text { Rainfall } \\
\text { Zone* }\end{array}$ \\
\hline C. baileyi C.T.White & $\begin{array}{l}\text { Warm sub-humid forest } \\
\text { (SE Qld, NE NSW) }\end{array}$ & 2 \\
\hline C. canescsns (Parlatore) S.T.Blake & $\begin{array}{l}\text { Rocky semi-arid scrubland } \\
\text { (southem WA) }\end{array}$ & 4 \\
\hline C. columellaris F. Mueller & $\begin{array}{l}\text { Sub-humid coastal plains } \\
\text { (NSW, Qld) }\end{array}$ & 2 \\
\hline C. drummondii (Parlatore) F. Mueller & $\begin{array}{l}\text { Sandy semi-arid scrubland } \\
\text { (coastal southem WA) }\end{array}$ & 4 \\
\hline C. endlicheri (Padatore) F. Mueller & $\begin{array}{l}\text { Cool infertile woodland } \\
\text { (NSW, ACT, Vic, Qld) }\end{array}$ & $3,4,5$ \\
\hline $\begin{array}{r}\text { C. glaucopbylla Thompsom } \\
\text { and Johnson }\end{array}$ & $\begin{array}{l}\text { Temperate woodland } \\
\text { (mainland Australia) }\end{array}$ & $3,4,5,6,7$ \\
\hline $\begin{aligned} \text { C. intratropica R.T. Baker } \\
\text { and H.G. Smith }\end{aligned}$ & $\begin{array}{l}\text { Wet tropical woodland } \\
\text { (WA, NT, Qld) }\end{array}$ & 1 \\
\hline $\begin{array}{c}\text { C. macleayana (F. Mueller) } \\
\text { F. Mueller }\end{array}$ & $\begin{array}{l}\text { Tropical \& subtropical } \\
\text { rainforest (NSW, Qld) }\end{array}$ & 1,2 \\
\hline C. monticola Garden & $\begin{array}{l}\text { Subtropical rocky outcrops } \\
\text { (SE Qld, NE NSW) }\end{array}$ & 2 \\
\hline C. muelleri (Parlatore) F. Mueller & $\begin{array}{l}\text { Dry sclerophyll forest } \\
\text { (northem NSW) }\end{array}$ & 2 \\
\hline C. oblonga Richard & $\begin{array}{l}\text { Temperate river flats } \\
\text { (Tas) }\end{array}$ & 4,5 \\
\hline C. preissii Miquel & $\begin{array}{l}\text { Temperate woodlands } \\
\text { (WA, SA,Vic, NSW) }\end{array}$ & 4,5 \\
\hline C. rhomboidea (Parlatore) Schlechter & $\begin{array}{l}\text { Temperate coastal sands } \\
\text { (SA, Tas, Vic, NSW, Qld) }\end{array}$ & $2,3,4,5$ \\
\hline C. roei (Endlicheri) F. Mueller & $\begin{array}{l}\text { Infertile semi-arid woodland } \\
\text { (inland WA) }\end{array}$ & 4 \\
\hline C. tuberrulata & $\begin{array}{l}\text { Infertile semi-arid woodland } \\
\text { (inland WA) }\end{array}$ & 4 \\
\hline
\end{tabular}

- Rainfall zones: 1 summer tropical, 2 summer subtropical, 3 uniform temperate, 4 winter (moderate to heavy), 5 winter (moderate), 6 arid (mainly summer), 7 arid (mainly winter) Colls and Whitaker 1990

C. endlicheri, black cypress pine, is found in woodlands west of the Great Dividing Range extending in a narrow arc from southern Queensland to northern Victoria. It typically occurs on rocky ridges and dry slopes, sites too 
droughty for eucalypts. Such stands are infrequently burnt and have the potential to reach considerable ages, while scattered individual trees within eucalypt dominated stands are more susceptible to fire-kill and therefore likely to be younger. This species was first sampled by Dunwiddie and Campbell in 1977, (La Marche et al. 1979). Currently a fire history study in Goobang National Park in the Harvey Range, NSW has shown tree rings to be essentially annual, (Bryant, pers. comm.). This result was achieved by comparing documented fire dates with the number of tree rings between fire scars. Sample trees also provided ages of around 50 years, while older trees, which were not sampled, indicated potential ages of perhaps 100 years. This promising result suggests that chronologies are possible when $C$. endicheri is sampled on selected sites.

C. rhomboidea, Port Jackson pine, is essentially a coastal species extending from Sydney to the central east coast of Tasmania. It is typically a small shrub or tree, occasionally growing to 20 metres and typically found on rocky exposed sites. Trees have been sampled at Bicheno, Tasmania by Podger in 1975 (La Marche et al. 1979). No chronologies have been published as the species possesses false rings, however successful chronologies may be possible by comparison with nearby celery top pine, Phyllocladus asplenifolia (Ogden 1978).

C. preissii, southern cypress pine, occurs sparingly in temperate woodlands across southern Australia and is typically found on deep sandy soils as a shrub or small tree. Stands were first studied in 1969 on Garden Island and the adjacent mainland at Naval Base in the far south-west of Western Australia (Pearman 1971). He showed rings to be clearly defined but crosscorrelation between trees was poor indicating that tree rings were not strictly annual. Several interesting observations were made from this data. Tree bole ages were \pm 50 years for the Garden Island trees, and from the Naval Base two trees were 100 years old, three $50-60$ years old and younger trees dated from the 1955 fire. This provided a possible relationship between fire and Callitris regeneration from which it may be interpreted that only three regeneration fires had occurred at the Naval Base over the past 100 years, although the exact fire dates remained indeterminate. Pearman's data showed no relationship between tree age and bole diameter suggesting the latter was more likely related to stand density. He suggested that X-ray densitometry may help to resolve the identification of intra-annual rings and thus allow accurate dating to be achieved. The usefulness of this technique has yet to be tested. He also noted that the wide oscillations in ring width plots, in at least some trees, was of the order of magnitude of the eleven year sunspot cycle, but accurately dated chronologies would be needed to 
evaluate such a relationship statistically. Pearman, with a special it atmospheric physics, was probably influenced in making this obse: earlier studies into such relationships (Douglass 1919, Costin 195- "1 the older trees a decade of better growth about 1920, corresponding a $a$ higher rainfall in the Perth region during this time, indicated a strong r lationship between rainfall and radial growth.

C. macleayana, stringybark or Port Macquarie pine, is the only rainforest species found in the tropical and subtropical rainforests, e.g. the Atherton Tableland and southern Queensland to Newcastle in NSW. Only one treering study has been published (Ash 1983). Ash examined the tropical population and demonstrated that tree rings were annual and the study stand had developed since the arrival of Europeans; ring widths correlated with various annual (October-September) climate parameters. He concluded that rainfall and cloudiness are associated with wide rings and atypical tracheid diameter patterns corresponded to years with atypical patterns of water availability.

C. intratropica, northern cypress pine, has a scattered and disjunct distribution across the northern monsoon belt in disjunct occurrences in the Kimberlies, the Top End and Cape York. Trees typically occur in small pure stands insulated from all but the most intense fires. The potential for developing accurate tree-ring chronologies for this species were predicted (Hillis and Banks 1976) since the climate is strongly seasonal and reliable with the summer monsoon rains and a strong winter drought. Hammer, in his study, assumed the rings were annual and derived tree-ring data from cores and discs from stands at Maningrida and Murganella in Amhem Land. These were used to derive site classifications based on height-diameter and diameter-age curves (Hammer 1981). The oldest trees approached 140 years -the second longest tree ages recorded for Callitris. Tree mortality has been observed in Northern Territory stands. This decline in Amhem Land stands has been dated 1940-1990 with peak losses around 1960 by cross-matching tree ring patterns between living and dead trees (Bowman and Panton, 1993). Relationships of $C$. intratropica tree rings with climate are currently being investigated by the author (Banks) using Hammer's samples.

C. glaucopbylla, white cypress pine, is the most widespread of the Callitris species extending from inland south-eastern Queensland south to inland Victoria with disjunct occurrences in those states and SA, NT and WA Much of this forest in the eastern states has been cleared for africulture. Residual stands persist on private and Crown lands and are mostly either managed for timber production or conserved in National Parks. The species was first investigated when three trees were sampled on The Pines ne ir Woomera in South Australia (Lange 1965). This study found trees roduc d 
about one tree-ring per year on average, in some years more and in others none. Wide rings correlated with seasons of significantly higher than average rainfall, and these could be cross-correlated between the sample trees, but the numbers of narrow rings differed between trees making accurate dating impossible. The study concluded that dating of this species growing under semi-arid conditions wasn't possible because of the high frequency of missing and double rings. Widespread sampling was undertaken in 1975-6 by Dunwiddie (La Marche et al. 1979). This study concluded that objective criteria needed to be developed to distinguish the true latewood from intraseasonal rings before accurate chronologies could be developed (Ogden 1978). A criteria for separating true from false rings will be most welcome for although rainfall is a major factor controlling annual diameter increment (Johnston 1975), at least on some sites a summer dry period causes the formation of intra-seasonal rings.

Two detailed studies with different objectives have succeeded in developing useful tree-ring chronologies. In one, a dendroclimatic study, a 650 year chronology was developed from a stand near Lake Barlee in WA (Perlinski 1986). This was correlated with the local 51 year rainfall and temperature records allowing the pre-European data to be interpreted as a surrogate climate record. At this location an annual growth season ring was apparently formed during the period of maximum summer moisture deficit. This chronology indicated several phases of aridity and humidity greater in magnitude if not duration than those of the European period.

The second study involving C. glaucopbylla stands along the Snowy River valley in the Kosciusko National Park was undertaken in the 1980s (Pulsford 1991, Pulsford et al. 1992, 1993). In carefully selected sites this species lays down a regular growth season ring and often lays down one or more intra season growth rings which are mostly less distinct than the growth season ring. Limitations to growth caused by low winter temperatures were the primary cause of the mostly distinct growth season ring, whilst periods of low soil moisture as a result of high summer temperatures, high evaporation and low rainfall are likely causes of irregular intra growth season rings. By combining tree-ring chronologies with written and oral histories, it demonstrated the value of dendrochronology as a tool for dating major ecological and anthropogenic events, e.g. European settlement, fire events, soil erosion, wheatfield regeneration of $C$. glaucophylla and rabbit invasion. The result provided a valuable insight to the understanding of past land use histories in the valley so essential to developing future management strategies. Of particular interest was the close relationship of Pulsford's (1991) forest fire history with Banks' (1982) history for sub-alpine snow gum forest. 


\section{Is wheatfield regeneration the norm?}

The second part of this paper is a preliminary report on the application of dendrochronology to determine the regeneration in pre-European period in stands of $C$. intratropica stands occurring on flat to undulating terrain.

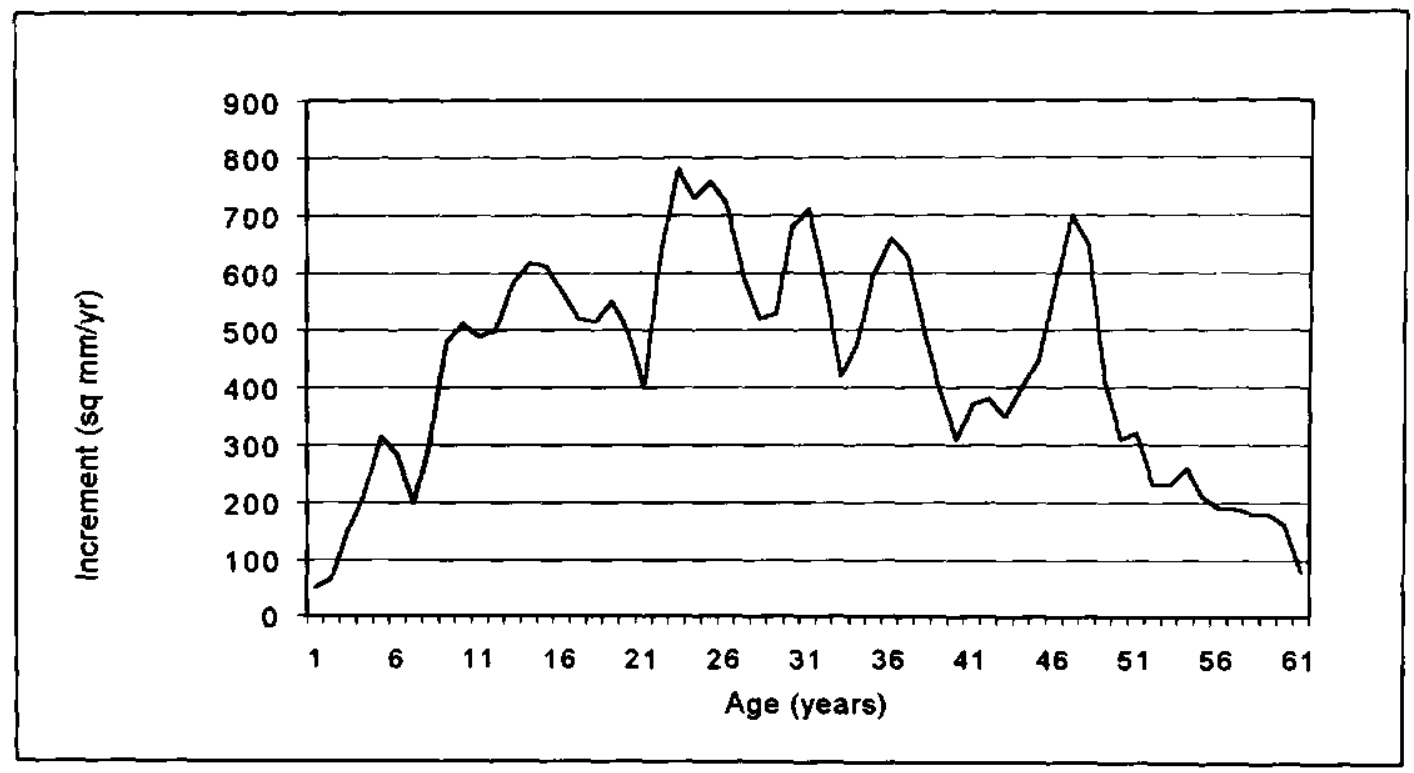

Figure 1. Typical annual increment pattern for Callitris intratropica from Murgenella, NT. Trees established in the $1900 \mathrm{~s}$ and $1850_{\mathrm{s}}$ were sampled in 1974. Data has been smoothed $(a+2 b+c) / 4$.

Controversy persists as to whether dense or scattered seedling regeneration is the usual ecological process for tree replacement. Within the recorded history of Callitris, extensive 'wheatfield' type regeneration of C. glaucopbylla and $C$. intratropica on flat to undulating terrain has occurred following disturbance (Swain 1928, Pulsford 1991, Bowman and Panton 1993). For example, dense regeneration is commonly seen on disturbed roadside sites in cypress country in western New South Wales. For dense regeneration to develop into open stands, as has been described for pre-European stands of $C$. glaucopbylla (Rolls 1981), dominant individuals would have to emerge. This is unlikely as dominance is weakly expressed in this genus, nor is it likely through attrition by severe drought or fire which would more than likely destroy the entire cohort. Alternately the extensive "wheatfield' type regeneration is an artefact of European driven disturbance and without manipulation these remain as 'locked' stands unable to develop a woodland structure. The answer may be had by examining early decadal growth patterns in trees established in pre-European times. 
Growth characteristics of C. intratropica trees pre-dating European disturbance at Murganella, NT, were chosen for study given the ease of chronology building in this species and access to core samples from trees sampled in 1974 (Hammer 1981). Tree ages gave establishment dates of circa 1900 and 1850, during the period of traditional Aboriginal land use practices. Annual bole cross-sectional area increments were derived from the tree-ring width data. Typical tree patterns are illustrated in Figure 1. The result shows rapidly increasing growth rates in the early decades of growth, which indicates that the trees developed under wide-spaced conditions. Growth reaches a maximum in the third to sixth decades depending on site conditions, and then slowly declines. This pattern is typical of free growth which is interrupted by short intervals of low rainfall, phytophagus insect damage or other aperiodic events. There was no evidence of a prolonged interval of suppressed growth in the early decades of growth which would be associated with 'wheatfield' regeneration. Since the trees established in two different periods, circa 1850 and 1900 , this lends confidence to accepting scattered individual seedling regeneration as the norm rather than 'wheatfield' type. Ecological factors associated with this type of regeneration and anthropogenic influences remain to be determined.

\section{Conclusion}

The over-riding message from Callitris tree-ring studies to date is to proceed with caution as it has dendrochronological potential to provide answers to environmental histories and anthropogenic influences so important to understanding the present state of ecosystems.

\section{References}

Anon 2000. Abstrats. International conference on Dendrochronology for the Third Millennium, Mendoza, Argentina (2-7 April 2000).

Ash, J. 1983 Tree rings in tropical Callitris macleayana F. Muell. Australiam Journal of Botany 31: $277-81$.

Baker, R.T. and Smith, H.G. 1910. A Research on the Pines of Australia. Sydney: Govt. Printer Sydney (Technical Education Series No 16 Technical Museum of NSW).

Banks, J.C.G. 1982. The use of dendrochronology in the interpretation of the snow gum forest. PhD thesis, The Australian National University.

Bowman, D.M.J.S. and Panton W.J. 1993. Decline of Calititis intratropica RT. Baker and H.G. Smith in the Northern Territory: implications for Pre- and Post-European colonisation fire regimes. Journal of Biogeography 20: 373-81. 
Colls, K and Whitaker, R 1990. The Australian Weather Book. Frenchs Forest, NSW: , ..id and Associates.

Costin, A.B. 1954. Ecosystems of the Monaro. Sydney: NSW Govt. Printer.

Datta, S.C. 1971. An Introduction to Gymnosperms. London: Asia Publ. House.

Douglass. A.E. 1919. Climate gycles and tree growth. Washington: Camegie Institute (Publ. 289).

Hammer, G.L. 1981. Site classification and tree diameter-height-age relationships for cypress pine in the top end of the Northern Territory. Austratian Forestry 44 (1): 35-41.

Hill, KD. 1998. Callitris (Cupressaceae). In Orchid, A. (ed.) Flora of Australia. vol. 48. Melbourne: CSIRO Publishing.

Hillis, W.E. and Banks, J.C.G. 1976. Climate change and tree rings. Rebuild 1: 1,2,5.

Johnston, T.N. 1975. Thinning studies in cypress pine in Queensland. Dept. of Forestry, Queensland (Research paper No 7, pp. 1-87).

Lange, R. T. 1965 Growth ring characteristics in an arid zone conifer. Transactions of the Royal Society of South Austraka. 89: 133-7.

La Marche, V.C., Holmes, R. L, Dunwiddie, P. W. and Drew, L. G. 1979. Tree-ring chronologies of the Southern Hemisphere 4. Australia. Tuscon, Arizona: Laboratory of Tree-ring Research, University of Arizona (Chronology series V).

Li, 1953. Journal of the Amold Arboretum 34.

Ogden, J. 1978. On the dendrological potential of Australian trees. Austratian Journal of Ecolology 3: 339-56.

Pearman, G.I. 1971. An exploratory investigation of the growth rings of Callitris presissii trees from Garden Island Naval Base. Westem Australian Naturalist 12: 12-17.

Pedinski, J.E. 1986. The dendrochronology of Callitris columellaris F. Muell. in arid subtropical continental Westem Australia. MA thesis, University of Westem Australia.

Pulsford, I. F. 1991. History of disturbances in the white cypress pine Callitis glaucopbylla, forests of the Lower Snowy River Valley, Kosciusko National Park. MSc. Thesis. The Australian National University, Canberra.

Pulsford, I. F., Banks, J.C.G. and Hodges, L. 1992. Environmental history: an example from the white cypress pine forests in the Australian Alps. In Grenier, P. and Good, R.B. (eds.) Les Alpes Australiennse Review De Geograpbie Alpine. Grenoble: Institute de Geographie Alpine, Tome LXXX, No 2-3: 65-95.

Pulsford, I.F., Banks, J.C.G. and Hodges, L. 1993. Land use history of the white cypress pine forests in the Snowy Valley, Kosciusko National Park. In J. Dargavel and S. Feary (eds). Australia's ever-changing forests II: Proceedings of the Second National Conference on Australian Forest History. 85-104.

Roig, F.A. (ed.) 2000. Dendrocronologia en America Latina. Ediunc Mendosa, Argentina: Universidad Nacional de Cuyo.

Rolls, E.C. 1981. A million wild acres: 200 years of man and an Austratian forest. Melbourne: Thomas Nelson.

Swain, E.H.F. 1928. The forest conditions of Queensland. Brisbane: Govt. Printer. 


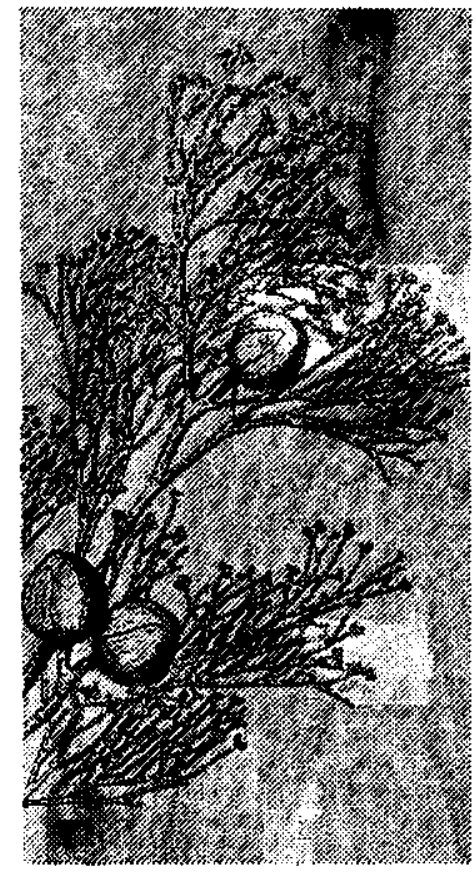

\title{
A new technique in dendroecology using Callitris
}

\author{
Mathew Searson \\ and Stuart Pearson
}

\section{Introduction}

Changes in the stem of a tree produce growth rings that leave a lasting record of the growth period. This period of incremental growth is a signal of the environment at the time the growth ring, or tree ring, was formed. In many situations, tree rings mark an annual cycle and so variations in width provide an annual chronology of the environment. The analysis of the timing and nature of ecological signals derived from tree rings forms the field of 'dendroecology' (Schweingruber 1996). Using careful site selection and the skeleton plotting technique there is an opportunity to glean fine resolution dendroecological information from the genus Callitris.

Callitris produce clear ring circuits (Schweingruber 1992) without the eccentricity caused by irregular trunk growth characteristic of Australian hardwoods. The continent-wide distribution of Callitris makes it attractive for dendrochronological investigations (Ogden 1978). It is resilient to termite attack and consequently living specimens and stumps are readily available where fire is absent.

Applications of Callitris as a dendrochronological tool have been limited by poor cross-dating results. Cross-dating is the systematic matching of tree ring pattems within and between trees and forms a basic principle of dendrochronology (Fritts 1976). This process identifies false (intra-annual rings) and missing rings in an individual tree's ring series to ensure annual 
dating control. It is based on the assumption that a signal common to a population of trees indicates a dominant environmental limiting facti: while false (intra-annual) and missing (absent) rings are due to micro-site and tree specific variation. So, through the process of cross-dating, particularly sensitive or complacent series are excluded and the remaining series can be interpreted to give an annual ring pattern of a regional ecological signal. The sample replication demanded by cross-dating also provides a control for between-tree and between-population variation.

Banks and Pulsford (Chapter 4 this volume) have described the history of Callitris dendrochronology. Cross-dating Callitris has been problematic, primarily due to the production of false rings. Lange (1965), was the first to investigate the potential of Callitris for dendrochronological applications. $\mathrm{He}$ was able to complete limited cross-dating using measurements of ring widths from just three disks cut from near Woomera (South Australia) by matching wide rings between trees. However, he found different numbers of thin rings between each large indicator ring. Lange (1965) conjectured that discrepancies in ring counts were due to false rings produced by Callitris in response to aseasonal rainfall. Pearman (1971) worked with 5 ring width series selected from 32 Callitris preissii trees cut from near Perth, Western Australia. He was also frustrated by false rings when attempting to cross-date. Trees were dated to 1873 and 1923 but cross-dating was not achieved due to false annual rings that confound calculations; therefore these dates are probably over-estimates.

Johnston (1975) used 40 years of girth measurements from thinning studies in the Goondiwindi area of Queensland to calculate annual diameter increments and these were closely correlated with rainfall $\left(\mathrm{R}^{2}=0.4\right)$. This supported Lange's (1965) ideas about the growth response of Callitris to rain.

La Marche et al. (1979) were apparently the first group to successfully cross-date Callitris during the pilot survey of the Southern Hemisphere by the Laboratory of Tree Ring Research (LTRR). This group used disks cut from between 5 and 15 Callitris trees at 24 sites in southern Australia. At only two of these sites-both in SW Western Australia-was cross-dating achieved within sites and the trees at the other 22 sites were not used due to an unacceptable number of false rings. The result of that preliminary survey did not entirely deter others, but it did stop the application of Americanstyle skeleton plotting until this project. In North America, skeleton plotting was instrumental in unlocking the bristlecone pine's famous dendroclimatological record (Fritts 1976) and has been widely applied elsewhere (LTRR 2001). 
In three studies subsequent to the La Marche group investigation, Callitris was successfully cross-dated and used for dendroecology. Julian Ash (1983) first achieved calibration of a cross-dated Callitris ring width chronology with an instrumental climatic record. Ash (1983) took wood samples from a stand of 13 Callitris macleayana on the Atherton Tablelands in northern Queensland. Five samples were cross-dated. Ash (1983) was able to predict the length of the wet season with this chronology $\left(\mathrm{R}^{2}=0.74\right)$. Working in a less seasonal, but slightly Mediterranean type climate, John Perlinski (1986) found a tighter relationship $\left(R^{2}=0.87\right)$. However, Perlinski (1986), more conventionally than Ash (1983), correlated ring width with mean annual rainfall data rather than season length. The 24-tree chronology was collected with a motorised corer and is the only one from an arid zone Callitris. Perlinski (1986) found false rings were easily identified because their margins were light in colour and spatially discontinuous. Finally, after overcoming problems of false rings, Ian Pulsford (1991) successfully cross-dated 5 Callitris from the lower slopes of the Snowy Mountains, New South Wales and used this chronology in the development of a forest fire history of the region.

The purpose of the present study is to test the accuracy of cross-dated Callitris samples taken from far north western New South Wales. False rings have at least hindered previous dendrochronological investigations using Callitris, so solving this problem is likely to enhance the use of Callitris in dendrochronological studies. This would mean that a 200 -year (at least) ecological record would be available for analysis of climate and the impact of humans on the Australian environment over most of the continent. Here, a new and objective technique is used to overcome the problem of false rings. The accuracy of this cross-dating is independently tested using carbon dating of tree rings.

\section{Method}

In this study a total of 50 trees were sampled using a 5 millimetre increment corer at 50 centimetres above the current ground surface. Lower branches emerged at 1 metre from the ground surface so cores were taken at 50 centimetres to avoid these (branches and roots introduce eccentricity to tree rings). Callitris were mainly limited to the sand dunes where they are protected from fire. Only two swale trees were sampled due to their scarcity. Intensive sampling at two regional sites on Bloodwood Station (130 kilometres north-west of Bourke, New South Wales) was done as a component of a palaeoclimatic study (Pearson et al. accepted). 


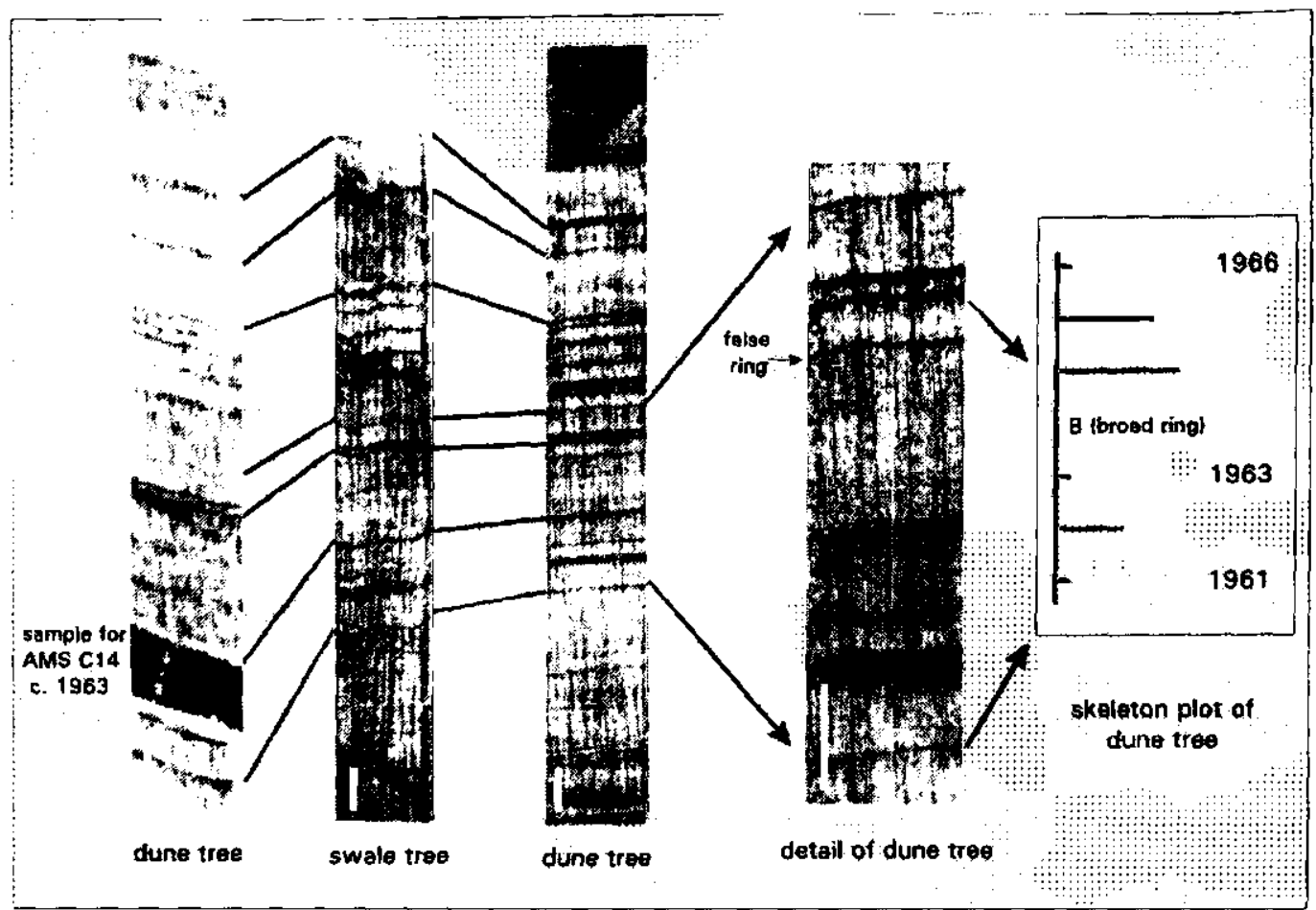

Figure 1. Photomicrographs of three sections of Callitris that have been crossdated using the swale tree method described in the text. Lines show the matching rings. The white line represents about $2 \mathrm{~mm}$.

Subjective criteria were used to initially identify rings and these decisions were recorded as skeleton plots for each core (Figure 1). These were graphical representations of ring pattern variations that showed event yearsgrowth being marked by relatively thin or wide rings (Schweingruber 1996). An enlarged section (Figure 1, right core) shows a false ring found in the dune tree but not present in the swale tree. The skeleton plot of the enlarged section shows the representation of ring width patterns. The result from the AMS ${ }^{14} \mathrm{C}$ sample (Figure 1, left core) is used on the skeleton plot as an absolute date. Skeleton plotting allowed visual comparisons of tree ring data. It was impossible to simultaneously compare ring width patterns of all samples under the microscope so the skeleton plots allowed the essence of patterns to be visually cross-dated (Stokes and Smiley 1968). Skeleton plots were produced by eye while observing each sample through a microscope at 20x magnification illuminated by a EUROMEX fibre optic light source. Difficult sections were examined at $40 \times$ magnification. Visual observations are recorded with pencil on standard graph paper-producing the skeleton plot (Figure 1). Each individual ring was detected and its width visually compared to the rings located immediately on either side of the ring of interest. The relative (compared to neighbours) size (determined by visual 
assessment) of the ring was reproduced on the skeleton plot. By convention, if a ring was thin relative to its neighbours it was drawn as a positive line on a skeleton plot. The length of the positive lines was inversely proportional to the width of the thin ring, so that a very thin ring was represented by a tall line with a maximum length of ten units. Average rings were simply indicated by a dot on the skeleton plot (Stokes and Smiley 1968). Broad rings were identified with a ' $\mathrm{B}$ ' on the skeleton plot (Figure 1). The convention of not highlighting average sized rings in this way reduces 'noise' and emphasised the event years leaving the basic 'skeleton' of the ring width patterns.

Initial problems with cross-dating trees from the same site were due to false (intra-annual) growth rings. These were erroneously identified as annual increments and as such could not be cross-dated with trees from the same stand. Application of subjective criteria such as tracheid size, wood colour and spatial continuity of rings were unsuccessful in separating false rings. The chronology of a swale tree, which had distinct rings in clear patterns, was used as a platform for cross-dating the more sensitive trees which were growing on the dune (Figure 1). This chronology helped identify the likely location of false rings that could be checked in the other cores.

COFECHA, a widely used computer cross-dating programme (Holmes 1983) was used to check that Callitris was, by any standard, a highly sensitive species. Consequently it was not necessary to use its mathematical techniques to cross-date the master chronology.

The accuracy of cross-dating was independently tested with Accelerator Mass Spectrometry (AMS) ${ }^{14} \mathrm{C}$ dating. Pre-treatment and processing was done by the Australian Nuclear Science and Technology Organisation (ANSTO). Two samples from the cross-dated series were taken from the 'bomb-pulse' period (post-1945) in which the atmospheric ${ }^{14} \mathrm{C}$ concentration allows dates to be annually resolved (Hua et al. 1999). This provides an independent test of master chronology.

\section{Results}

Cross-dating between trees and sites was successful and 20 trees were included in a regional master chronology-the first constructed in eastern, arid Australia (Pearson et al. accepted). Figure 1 shows cross-dating between three of the trees in the master chronology and how the swale tree was used to identify false rings. Initial results show the master chronology is significantly correlated with rainfall and analysis is continuing (Searson and Pearson in prep.). We limit the results presented here to evidence of how the method works and that cross-dating was successful. 
Two samples, predicted from cross-dating to have been formed in 1964 and 1968 were submitted for radiocarbon analysis. The dated rings were found to be 3-5 years older than estimated (Table 1). The error on sample OZE840 is due to a plateau in the calibration curve (see Hua et al. 1999).

Table 1. Comparison of dendrochronological and radiocarbon results.

\begin{tabular}{lcccc}
\hline $\begin{array}{l}\text { ANSTO } \\
\text { code }\end{array}$ & $\begin{array}{c}\text { Predicted } \\
\text { age (dendro- } \\
\text { chronology) }\end{array}$ & $\delta\left({ }^{13} \mathrm{C}\right)$ & $\begin{array}{c}\text { Percent } \\
\text { modem carbon } \\
(1 \sigma \text { error })\end{array}$ & $\begin{array}{c}\text { Calibrated age } \\
\text { (calendar years) }\end{array}$ \\
\hline OZE840 & $1964 \mathrm{AD}$ & -21.4 & $120.45 \pm 0.53$ & $1959-1962$ \\
OZE841 & $1968 \mathrm{AD}$ & -22.6 & $132.43 \pm 0.49$ & 1963 \\
\hline
\end{tabular}

\section{Discussion}

The frustration of cross-dating in Callitris is, we believe, related to decisions made in site selection. The protocols of site selection, and ultimately the success of dendrochronology, are based on the theory of site selection. This theory dictates that trees should be sampled in stressed locations to maximise their sensitivty to environmental conditions. Such sites are generally described as sloping and/or run-off locations where water is resident only during the growing season and does not remain to contribute to growth in the following seasons (Fritts 1976). Lange (1965), Pearman (1971) and La Marche et al. (1979) found an abundance of false rings in Callitris samples indicating that this genus is very sensitive to climate. The sensitivity of Callitris, manifest by quick growth response to rainfall, is a result of the long-term evolution of Callitris in the Australian environment (Page and Clifford 1981). Callitris grows in response to extreamely unpredicitable rainfall events derived from the penetration of southern and northem moist air into the high pressure systems centred on the Australian landmass. Callitris is extremely sensitive to low soil moisture conditions (Attiwill and ClaytonGreen 1984) and probably responds opportunistically to incursions of moisture. Such a response predisposes Callitris to the production of false rings and indicates that sampling Callitris in stressed locations will compound this problem.

Water stress is less likely to occur in run-on and mesic sites and the annual growth is more reliable. This explains the successes of Perlinksi (1986) and Pulsford (1991) where relatively reliable seasonality of the Western Australian climate and the longer moisture residence on southern slopes in the Kosciusko site (Clayton-Green and Ashton 1990) res. " in 
fewer false rings and better cross-dating. In this study the presence of trees that had no false rings was due to moist swale micro-environmental conditions that buffered the Callitris from hyper-sensitivity to rainfall events.

Sensitive, run-off locations such as the dunes in the Paroo, or indeed the slopes of the Snowy Mountains (Pulsford 1991), are likely to promote false rings in Callitris because the tree switches quickly into growth at each rainfall event largely independently of the annual growth pattern. Then, the shallow rooted Callitris (Perlinski 1986) switch out of growth as the soil moisture in the top 0.5 metre of soil evaporates or drains away. In the swales where runon occurs and the finer more organic soil holds moisture, this switching is slower and more likely to reflect annual cycles in soil moisture. In these locations the 'noise' of the hyper-sensitive Callitris may be dampened.

\section{Conclusion}

The use of swale trees as a platform which is more complacent to aid crossdating is a new approach. North American tree species tend to be more complacent so site selection theory seeks to amplify the sensitivity of the sampled trees. However, in Australia, to reduce the difficulties of false rings, we believe site selection should seek to dampen the sensitivity of Callitris. In the present work the use of a more complacent swale tree ring series as a basis for cross-dating has proven to be effective to within five years of the actual date.

Using the technique outlined here Callitris can be cross-dated to within an accuracy of 5 years. With further investigation of this technique resolution may be improved. We suspect the error may represent over compensation for false rings because some of the swale tree's growth may be continuous during a series of wet years. However, with the current precision Callitris can be used to obtain reasonably fine dates for ecological events. This has applications for dating rainfall and other climatic conditions (Searson and Pearson in prep.), the germination dates of forest stands, the impacts of silvicultural activity, the effects of management changes such as the cessation of Aboriginal burning and the arrival of rabbits. Together with the work of Perlinski (1986), Ash (1983), and Pulsford (1991) the present work contributes to the mounting evidence that Callitris can be used for dendrochronology. 


\section{Acknowledgments}

Funding for AMS ${ }^{14} \mathrm{C}$ dates was obtained with AINSE grant 00/122. A NSW Linnean Society grant supported the work. Professor Brian Timms was an inspiration to the work. Mr Quan Hua (ANSTO, Physics Division) processed AMS samples and discussed the results. The owners of Bloodwood and Muella Stations are sincerely thanked.

\section{References}

Ash, J. 1983. Tree rings in tropical Callitris macleayana F. Muell. Australian Journal of Botany 31: $277-81$.

Attiwill, P.M. and Clayton-Green, K.A. 1984. Studies of gas exchange and development in a subhumid woodland. Journal of Ecology 72: 285-94.

Clayton-Green, K.A. and Ashton, D.H. 1990. The dynamics of Callitris columellaris-Eucalyptus albens communities along the Snowy River and its tributaries in south-eastern Australia. Australian Journal of Ecology 38: 403-32.

Fritts, H.C. 1976. Tree rings and climate. London: Academic Press.

Holmes, R. L. 1983. Computer-assisted quality control in tree-ring dating and measurement. Tree-Ring Bulletin 43: 69-78.

Hua, Q., Barbetti, M., Worbes, M., Head, J., and Levchenko, V.A. 1999. Review of radiocarbon data from atmospheric and tree ring samples for the period 1945-1997 AD. LAW A Joumal 20: 261-83.

Johnston, T.N. 1975. Thinning studies in cypress pine in Queensland. Department of Forestry Queensland (Research Paper No. 7).

La Marche, Jx., V.C., Holmes, R.., Dunwiddie, P.W., Drew, L.G. 1979. Tree-ring cbronologies of the southerm bemisphere: Australia., Chronology Series V. Vol. 4. Tucson: Laboratory of Tree-Ring Research, University of Arizona.

LTRR (Laboratory of Tree-Ring Research, University of Arizona) 2001. http://www.ltrr.arizona.edu.au/publications.html.

Lange, RT. 1965. Growth ring characteristics in an arid zone conifer. Transactions of the Royal Society of South Australia 89: 133-7.

Ogden, J. 1978. On the dendrochronological potential of Australian trees. Australian Journal of Ecology 3: 339-56.

Page, C.T. and Clifford, H.T. 1981. Ecological biogeography of Australian conifers and ferns. In A. Keast (ed), Ecological biogeography of Australia: Pant Two - Flora. The Hague: Dr. W. Junk. pp. 471-98.

Pearman, G.I. 1971. An exploratory investigation of the growth rings of Callitris preissii trees from Garden Island and Naval Base. West Australian Naturalist 12: 12-17.

Pearson, S., Searson, M. and Gayler, L. accepted. Preliminary results from tree increment and playa sediment cores from the Paroo, north-westem New South Wales, Australia. Quatemary International 
Petinski, J.E. 1986. The dendrochronology of Callitris columellaris F. Muell in arid, subtropical continental Western Australia. Masters thesis, University of Western Australia, Perth.

Pulsford, I.F. 1991. History of disturbances in the white cypress pine (Callitris glaucopbylla) forests of the lower Snowy River Valley, Kosciusko National Park. Unpubl. Masters Thesis, Australian National University.

Schweingruber, F.H. 1992. Annual growth ring zones in woody plants in southem Australia. LAWA Bulletin 13(4): 359-79.

Schweingruber, F.H. 1996. Tree rings and environment: dendroecology. Beme: Paul Haupt Verlag.

Stokes, M.A. and Smiley, T.L 1968. An introduction to tree-ring dating. Chicago: University of Chicago and London Press. 


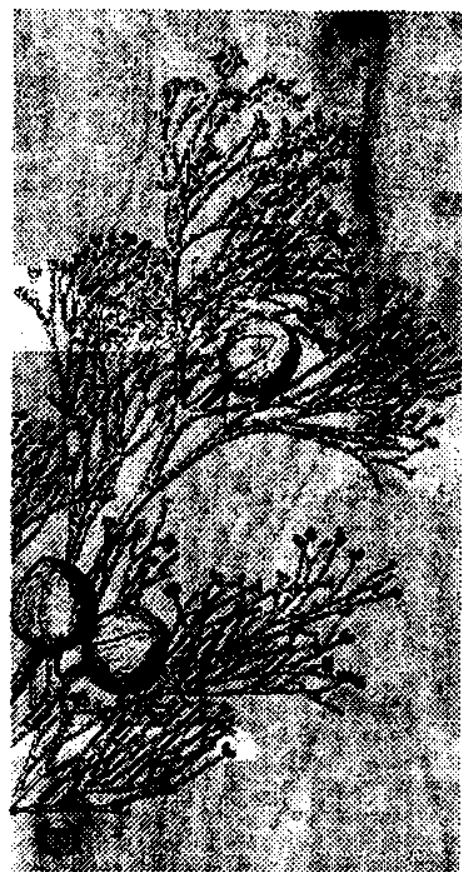

6

Identifying a

white pine-ironbark

community from

phytoliths

Diane M. Hart

\section{Introduction}

There are often situations in palaeoenvironmental research where pollen is not available to provide evidence of the past vegetation and hence environment. Phytoliths, or plant opal, are being used in these cases to provide the missing evidence. Phytoliths are microscopic (5-200 micron) sized solid opaline particles which persist in sediments for tens of thousands and in some cases for millions of years. This area of research is in its infancy.

Soluble silica from the soil solution is taken into plants, concentrated and deposited in the leaves, stems and roots in solid form as phytoliths. When plants die, the phytoliths they contain enter the soil. To date, the use of phytoliths has been largely confined to palaeoenvironmental and archaeological research. In these studies shape characteristics are of primary importance in the erection of assemblages of phytoliths (consisting of those shapes present and their frequency) which are then considered to be diagnostic of a particular environment (Piperno 1987).

Many palaeoenvironmental studies establish a phytolith reference assemblage from the sediment under modern vegetation. In so doing they assume that the modern vegetation communities are similar to those of the past, the processes affecting the phytolith before and after it is incorporated into the sediment are the same and that the assemblages are indeed representative of that community. 


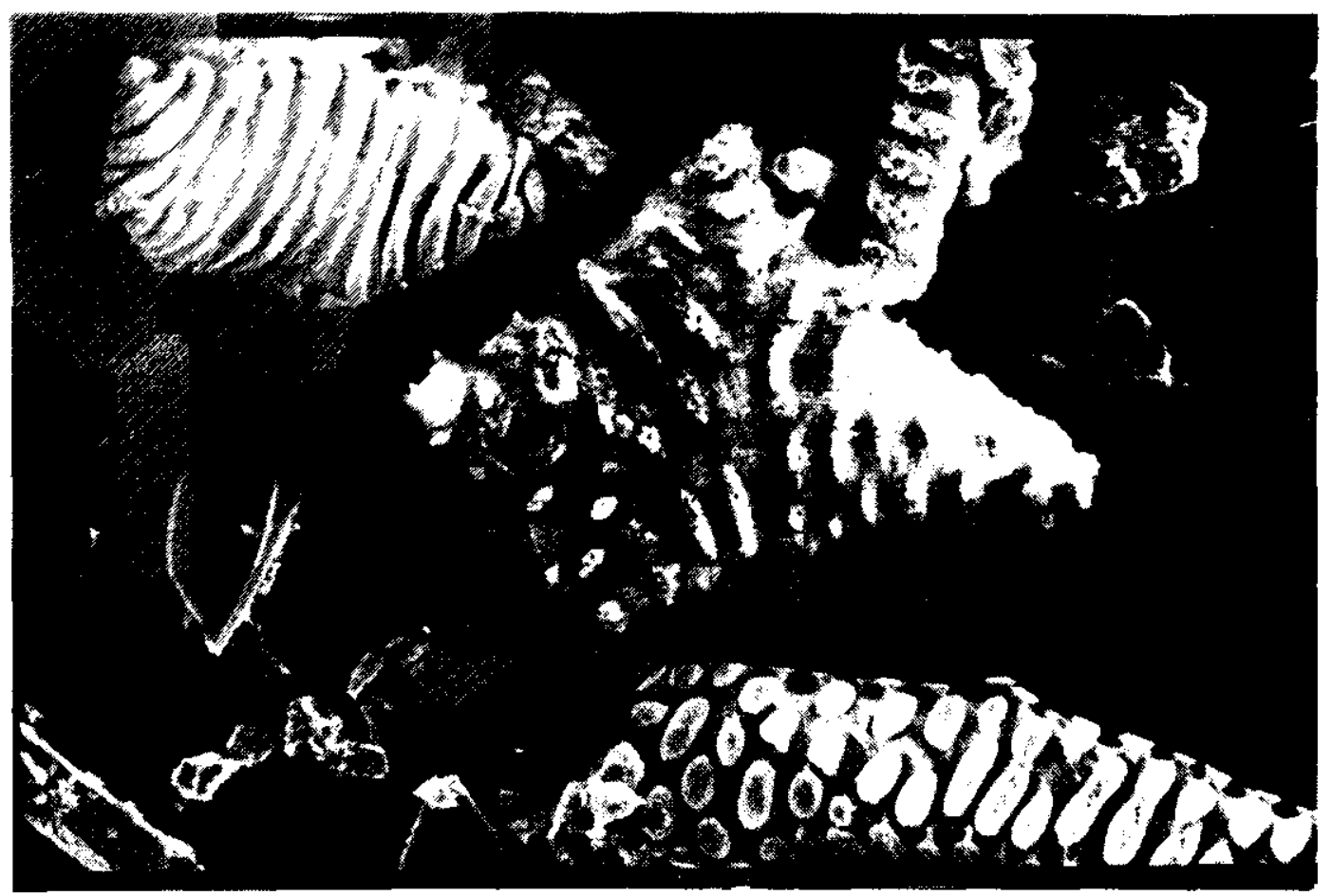

Figure 1. Phytoliths. Example of ridged and rough surface ornamentation; Acacia calamifolia, Pilliga East State Forest. The bar is $10 \mu \mathrm{m}$.

Both botanical and pedological processes influence the sediment phytolith assemblage. The botanical processes include species diversity and proportion, relative amount of phytolith production and its size range (Piperno 1987); the pedological processes include horizontal and vertical displacement of the phytoliths and dissolution rates (Hart and Humphreys 1996). What is needed in any area is a thorough understanding of all processes and how they affect the modern assemblage before examination of fossil assemblages can be attempted. However, the relationships between phytolith assemblages in modern vegetation communities are rarely examined. In this study, the soil phytolith assemblages in two environments and under several vegetation communities were compared to see if the individual communities could be differentiated.

\section{Field sites}

The field sites are located in the Pilliga East State Forest and at Marsfield, Sydney. The surface geology of the Forest comprises upper Jurassic Pilliga Sandstone and derived sediments. The soils are Solodized Solonetz (Stace et al. 1968). Annual rainfall averages $625 \mathrm{~mm}$ with a summer maximum, but 
varies greatly. The vegetation is a sclerophyllous closed to open-forest with a heath understory and comprises a mosaic of vegetation communities.

The three vegetation communities studied are located along Dunwerian Road (see map page 92). The Forest is a white pine-ironbark association comprising mid-height open-woodland (10-20 percent cover) of Callitris glaucophylla (white pine, height to 15 metres) and Eucalyptus crebra (narrowleaved ironbark, height to 20 metres) with Acacia tindaleae (golden-top wattle) in the shrub layer and a mixed herb layer. The Mallee community comprises Eucalyptus viridis (green mallee) in the mallee (many stemmed) form (height to about 7 metres) and the shrub layer is dominated by Dodonaea viscosa ssp. cuneata (hop bush) with a herb layer containing various grasses. It is a closed to open-woodland with crowns just touching and it has an abrupt boundary with the surrounding broom plain. Bioturbation (mixing by soil fauna) and phytolith distribution in this soil has been described in Hart (1992) and Hart and Humphreys (1996). The Broom Plains comprise very low heath of Melaleuca sp. (tea tree), Acacia sp. (wattle) and Calytrix tetragona (common fringe-myrtle) 2 to 5 metres tall. The ground cover comprises lichens and moss mats between the shrubs.

The Marsfield study site is located between 40 and 50 metres above sea level on a $5-6^{\circ}$ slope in Hawkesbury Sandstone on the Hornsby Plateau, Marsfield, 12 kilometres north west of Sydney (now directly under the M2 tollgates). The soils are Podzolics (Stace et al. 1968). Annual rainfall averages $1211 \mathrm{~mm}$ with a summer maximum. The vegetation is a sclerophyllous woodland of Eucalyptus species, including E. haemastoma (scribbly gum) and E. gummifera (red bloodwood), with a heath understory of Banksia, Acacia, Hakea and Grevillea, and a ground cover including Pteridium esculentum (bracken).

\section{Methods and results}

The phytolith assemblages were examined from the topsoil beneath three vegetation communities in the Pilliga (Broom Plains sites 1, 2, 3, Mallee and Forest) and from one community in Sydney (Sydney sites 1 and 2 located at upper and mid slope positions respectively). At each site, over a 100 square metre sampling grid, ten pinch samples of identical volume were taken from the surface soil after litter had been removed. Two separate sets of samples were taken from one Broom plain site (Broom $3 a$ and $3 b$ ). 
Table 1. Differences in phytolith morphology between sites

\begin{tabular}{|c|c|c|c|c|c|c|}
\hline \multirow[t]{3}{*}{ Site } & \multicolumn{6}{|c|}{ Morphology ( $\%$ of count) } \\
\hline & \multirow{2}{*}{$\begin{array}{l}\text { Short } \\
\text { grass } \\
\text { cells }\end{array}$} & \multicolumn{2}{|c|}{ Regular sheets } & \multirow{2}{*}{$\begin{array}{c}\text { Hairs } \\
\text { and } \\
\text { prickles }\end{array}$} & \multicolumn{2}{|c|}{ Ridged and rough } \\
\hline & & Thin & Thick & & $\begin{array}{l}\text { Thick } \\
\text { rods }\end{array}$ & $\begin{array}{l}\text { Thick } \\
\text { regular } \\
\text { sheets }\end{array}$ \\
\hline Broom 1 & 12.7 & 0.0 & 9.2 & 33.5 & 16.2 & 7.5 \\
\hline Broom 2 & 9.0 & 1.8 & 17.8 & 22.9 & 19.6 & 8.4 \\
\hline Broom 3a & 11.8 & 3.8 & 11.4 & 23.2 & 10.0 & 8.1 \\
\hline Broom 3b & 8.5 & 2.4 & 19.1 & 19.5 & 11.8 & 12.2 \\
\hline Mallee & 27.9 & 1.0 & 2.4 & 13.0 & 5.3 & 0.5 \\
\hline Forest & 23.2 & 1.5 & 8.8 & 9.4 & 5.2 & 0.5 \\
\hline Sydney 1 & 5.1 & 12.2 & 21.9 & 7.1 & 30.0 & 18.3 \\
\hline Sydney 2 & 5.6 & 7.1 & 31.5 & 11.1 & 23.8 & 25.4 \\
\hline
\end{tabular}

Phytoliths were extracted from the silt fraction of each sample and mounted on microscope slides for counting of morphological types using a Phytolith Key for disarticulated shapes (for details see Hart 1990, 1992). Phytoliths were counted until 200 regular (shapes occurring in the sample repetitively) phytoliths over 2 microns in diameter were counted and placed into a category according to the Key. Each morphological type score was expressed as a percentage of total regular grains and a cluster analysis was undertaken to show similarities between samples (Figure 2). The analysis used the Euclidean distances of unweighted pair-group arithmetic averages and was performed by the MultiVariate Statistical Package of Kovach (1993).

Selected categories of morphological types were expressed as a proportion of the count and used to examine differences in morphology between the samples (Table 1).

\section{Discussion}

At the basis of many palaeoenvironmental reconstructions utilizing phytoliths is the erection of an assemblage of phytoliths which is considered to be diagnostic of a particular environment. Most of the reconstructions thus far incorporate the information from phytolith studies with that obtained from parallel pollen studies (Alexandre et al. 1996) or with other cross-disciplinary evidence (Pearsall and Trimball 1983). However, there are many circumstances where pollen is not available and this is where phytolith studies may 
be of great value. In many studies to date, the phytolith evidence doesn't come from the assemblages themselves, but from the morphology of phytoliths within the assemblages, which experience in the environment has led to the belief are specific to species in the extant vegetation (Piperno 1985). Thus the identification of plant communities in these instances is based on one or two individual phytoliths, not on the complete assemblage. The present study utilizes the whole assemblage of regular forms.

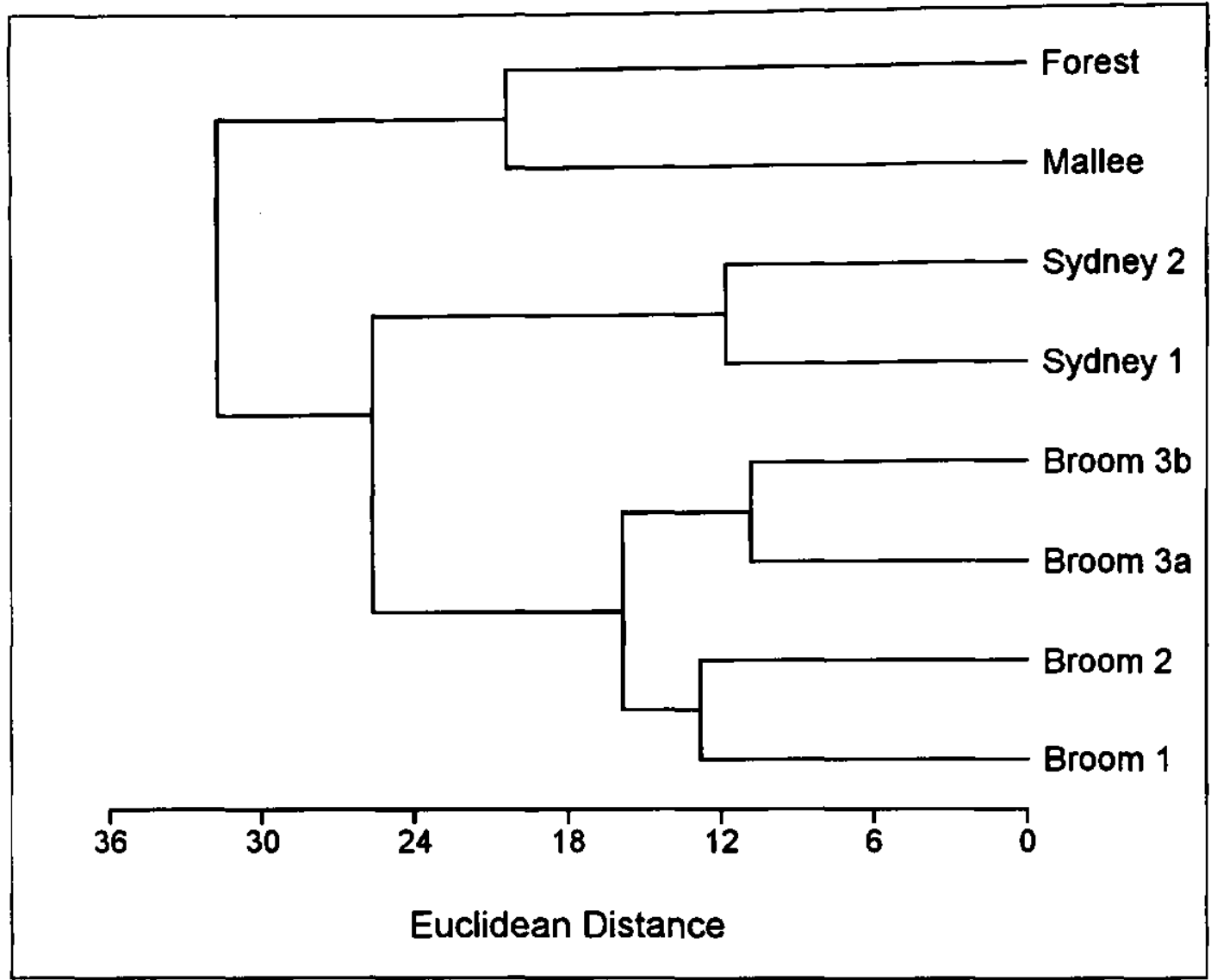

Figure 2. Dendrogram showing results of cluster analysis (unweighted pair group method using arithmetic averages. Close linking illustrates similarity. The two Pilliga woodlands (Forest and Mallee) cluster together showing similarity, but are not as similar as the Broom 3a and $3 \mathrm{~b}$ sites.

The reproducibility of assemblages is an important consideration which has not previously been assessed. Figure 2 shows that the two samples from Broom plain (Broom 3a and 3b) cluster together. The comparison of these two sets of samples from one Broom community show that the assemblages erected were similar thus it is reasonable to assume that the phytolith assemblage erected for each sample is representative of the site. 
The Sydney assemblages are very different from any of the Pilliga, although nearest to those of the Broom (Figure 2). Species differences between the two environments appear to produce sufficiently differing assemblages without our needing to know details of all individual species phytolith morphology. However, within the same zone (Pilliga), the distinction between vegetation communities may not be as clear. While the heath vegetation (Broom) clusters separately, the two woodland communities (Mallee and Forest) do not. This is possibly because trees contribute few but similar phytoliths while the understory, which is similar in both communities, produces large quantities of sometimes distinctive phytoliths, particularly grass short cells and ridged and rough morphologies (Table 1, Figure 1).

Processes other than botanical may also lead to differences between assemblages, even within the one community. Fire has been shown to remove platy phytoliths from topsoil assemblages. In a study which monitored the effects of fire on phytolith assemblages, it was found that water movement on the site after fire selectively removed the sheet-like plates and rods from the assemblage, considerably altering both the morphology and the amount of plant material available for incorporation into the soil (Hart 1996). At the time of this study, Broom 3 was last burnt in 1966/67, while the remaining sites last burned in 1951. Litter studies show that the litter accumulation-decomposition rate had not reached steady state on site Broom 3 (Hart 1995), whereas it had in the Forest and Mallee sites. These factors contribute to the differences in soil phytolith assemblages between the sites.

Many soil fauna return the phytoliths to the soil surface by way of mounding, faecal pellets and runways. They may also selectively remove some vegetation types and place them in storage away from the main cycling of nutrients, both for food and building materials. The underground workings of both ants and termites are very extensive and it has been shown that the activities of soil fauna are capable of selectively altering the soil phytolith assemblage morphology as well as its distribution pattern (Hart and Humphreys 1996), thus the actual location within the soil where samples are removed for phytolith analysis is important in material where species such as termites are operating. This may prove to be a problem where several species are active in different layers of the soil. 


\section{Conclusions}

This study begins to demonstrate both similarities within soil phytolith assemblages from the same vegetation community and variability between differing communities in the same environment. Within the Pilliga, differentiation between the white pine-ironbark and mallee communities, both woodlands with similar understories, was not achieved. However, the study does demonstrate that woodlands from differing climatic environments might be able to be separated on the basis of their soil phytolith assemblages which is useful in cases where a parallel pollen study is not available. Subsequent investigations into process (i.e. Hart and Humphreys 1996) demonstrate the processes which are responsible for phytolith assemblage production in woodlands.

\section{Acknowledgments}

The support of Macquarie University and permission to conduct the research by the Forestry Commission of New South Wales are gratefully acknowledged.

\section{References}

Alexandre, A., Meunier, J-M., Lézine, A-M., Vincens, A. and Schwartz, D. 1996. Grassland dynamics in intertropical Africa during the late Holocene: phytolith analysis. Abstracts of the First European Meeting on Phytolith Research, 23-26 September 1996, Madrid, Spain. p 63.

Hart, D.M. 1990. Occurrence of the 'Cyperaceae'-type phytolith in Dicotyledons. Australian Journal of Systematic Botany, 3: 745-50.

Hart, D.M. 1992. A field appraisal of the role of plant opal in the Australian environment. $\mathrm{PhD}$ thesis, Macquarie University.

Hart, D.M. 1995. Litterfall and decomposition in the Pilliga State Forests, New South Wales, Australia. Australian Journal of Ecology, 20: 266-72.

Hart, D.M. 1996. Phytoliths and fire in the Sydney Basin, New South Wales, Australia. Abstracts of the First European Meeting on Phytolith Research, 23-26 September 1996, Madrid, Spain. p 15.

Hart, D.M. and Humphreys, G.S. 1996. The mobility of phytoliths in soils: pedological considerations. Abstracts of the First European Meeting on Phytolith Research, 23-26 September 1996, Madrid, Spain. p 16.

Kovach, W.L. 1993. MVSP: A MultiVariate Statistical Package for IBM PCs, ver. 2.1. Kovach Computing Services, Pentraeth, Wales, UK.

Pearsall, D.M. and Trimble, M.K. 1983. Phytolith analysis of soil samples. Report 18 in: Clark, J.T. and Kirch, P.V., (Eds) Archaeological investigations of the Mudlune.W'aimea- 
Kawaibae Road Corridar, Island of Hawa'i. Dept. of Anthropology, Bemice P. Bishop Museum and Department of Transportation, Highways Division, State of Hawai'i. (Report 83-1).

Piperno, D.R 1985. Phytolithic analysis of geological sediments from Panama. Antiquity, LIX: 13-19.

Piperno, D.R 1987. Phytolith analysis: an archaeological and geological Perspective. San Diego: Academic Press.

Stace, H.C.T., Hubble, G.D., Brewer, R, Northcote, K.H., Sleeman, J.R, Mulcahy, M.J. and Hallsworth, E.C. 1968. A bandbook of Australian soils. Glenside, South Australia: Rellim Technical Publications. 


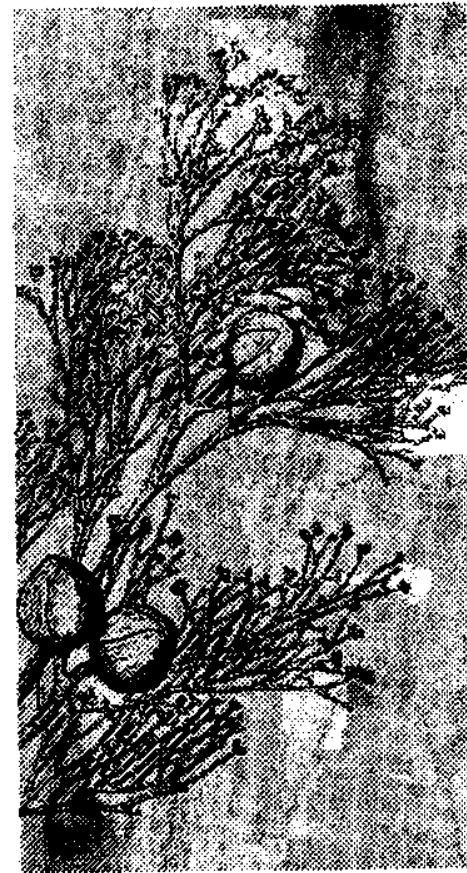

\section{Assessing changes in cypress pine forests from old stumps}

\section{Ian Lunt, David Parker and Wayne Robinson}

\section{Introduction}

As described in Eric Rolls' classic book, A Million Wild Acres, Australia's cypress pine forests and woodlands have a rich and diverse history. Not surprisingly perhaps, given the large area over which white cypress pine (Callitris glaucopbylla) occurs, some details of the accepted history of Callitris forests have recently been challenged and debated. Whilst ecologists have entered this debate (e.g. Norris et al. 1991, Benson and Redpath 1997), the debate has focussed on alternative interpretations of archival and historical literature, and little new ecological information has been contributed.

Rather than continuing to re-interpret or debate archival information, an alternative research strategy is to attempt to collect new ecological information from the forests themselves. Two recent historical reports on Callitris forest reserves in western New South Wales (Curby 1997, Allen 1998) have suggested that the cut stumps which survive in many Callitris forests may yield valuable information on pre-settlement stand structures, since Callitris wood is resistant to termite attack and decomposes slowly, and most reserves have rarely been burnt, thereby enhancing stump persistence. Thus, studies of cut stumps could perhaps yield valuable, site-specific information on how Callitris forests have changed over the past century.

The aim of this project was to see whether new ecological information could be gathered from cut stumps to enhance our understanding of past 
changes in Callitris forests, and thus to ask: 'can the forests teach us anything which our books cannot?'

The project was undertaken in Terrick Terrick National Park in northem Victoria, at the southern edge of the Callitris forest belt. The Terrick area was settled by squatters in the mid-1840s and settlers in the $1860 \mathrm{~s}$, and was managed by the Forests Commission of Victoria from the mid-1920s until becoming a conservation reserve in 1986. The vegetation was described as 'open forest land ... lightly timbered' in the 1860s (Willis 1863). Today, the reserve supports three main vegetation types: a silviculturally managed stand of single-aged Callitris, which regenerated in the late 1800s; an open eucalypt woodland with few Callitris or eucalypts (yellow box, Eucalyptus melliodora and grey box, E. microcarpa): and rocky granitic outcrops dominated by scattered yellow box. Only the first two zones are discussed in this study.

\section{Methods}

The study was conducted by measuring all stumps and trees in a grid of 178 , $20 \times 20$ metre quadrats across the reserve. In each quadrat, the girth, cutting style and decomposition status of all stumps was assessed. Three types of Callitris stumps could be identified, based on differences in cutting styles: (1) tall stumps (50-90 centimetres tall) cut by axe before 1925; (2) short stumps (less than 15 centimetres tall) cut by axe between 1925 and 1960; and (3) short stumps (less than 15 centimetres tall) cut by chainsaw between 1960 and 1986.

The density of Callitris trees in 1860 (before the main pulse of pine regeneration) was estimated from the sizes of cut stumps. Whilst the cutting period of every stump was known, the growth rate of individual trees (i.e. stumps) was unknown. Consequently, an arbitrary growth rate had to be assumed, so that the size of each tree in 1860 could be estimated. To do this, it was assumed that all trees grew at the average growth rate of the trees which regenerated in the late $1800 \mathrm{~s}$. This arbitrary choice of growth rates has undoubtedly introduced some errors to estimates of past tree densities, but alternative research strategies are unavailable.

\section{Results}

Most stumps in the reserve were cut after 1925 by axe or chainsaw as part of forestry thinning and felling practices, and relatively few stumps were cut 
before this period (Table 1). Only 86 of the 1060 measured stumps are thought to have been felled before 1925 .

Table 1. Number of Callitris stumps of each cutting style recorded from quadrats in Terrick Terrick National Park, Victoria

\begin{tabular}{llc}
\hline Stump style & Probable cutting period & $\begin{array}{c}\text { Number } \\
\text { of stumps }\end{array}$ \\
\hline Axe cut, c. 50-90 cm tall & $1850-1925$ & 69 \\
Very old, no clear cut, possibly fallen & Unknown, assumed pre-1925 & 17 \\
Axe cut, 5-10 cm tall & $1925-1960$ & 552 \\
Flat, chainsaw cut, 10-15 cm tall & $1960-1987$ & 422 \\
\hline
\end{tabular}

Table 2. Estimated changes in Callitris density over the past 140 years at Terrick Terrick National Park.

\begin{tabular}{lcc}
\hline Date & \multicolumn{2}{c}{ Callitris } \\
& Forest & Woodland \\
\hline 1860 & 50 & 8 \\
Late-1800s regeneration & over 349 & over 37 \\
1925 & 331 & 35 \\
1960 & 217 & 21 \\
1998 trees & 130 & 11 \\
1998 trees and saplings & 172 & 22 \\
\hline
\end{tabular}

Estimates of the size of each stump in 1860 suggest that about 50 Callitris per hectare grew in the dense Callitris zone at Terrick Terrick in 1860 compared to 172 Callitris per hectare nowadays (Table 2). Only eight Callitris per hectare appear to have grown in the open woodland zone in 1860 , compared to 22 now (Table 2). Thus, present Callitris stands are estimated to be about three times as dense as those which occurred in the $1860 \mathrm{~s}$.

By taking account of stump cutting styles, changes in Callitris densities throughout this century can be calculated (Table 2). Thus, the density of Callitris in the forest zone increased from 50 trees per hectare in the $1860 \mathrm{~s}$ to over 349 in the late- $1800 \mathrm{~s}$. The real density of regeneration in the late1800 s may have far exceeded this estimate, as this only includes those stumps which survived until the end of the twentieth century. This dense stand was then progressively thinned and felled by the Forests Commission to 331 Callitris per hectare in 1925, 217 in 1960, and just 130 in 1988, when 
timber harvesting ceased. New regeneration since the 1970s gives a total present density of 130 mature Callitris and $\mathbf{4 2}$ young saplings per hectare. Similar changes have taken place in the open woodland belt (Table 2).

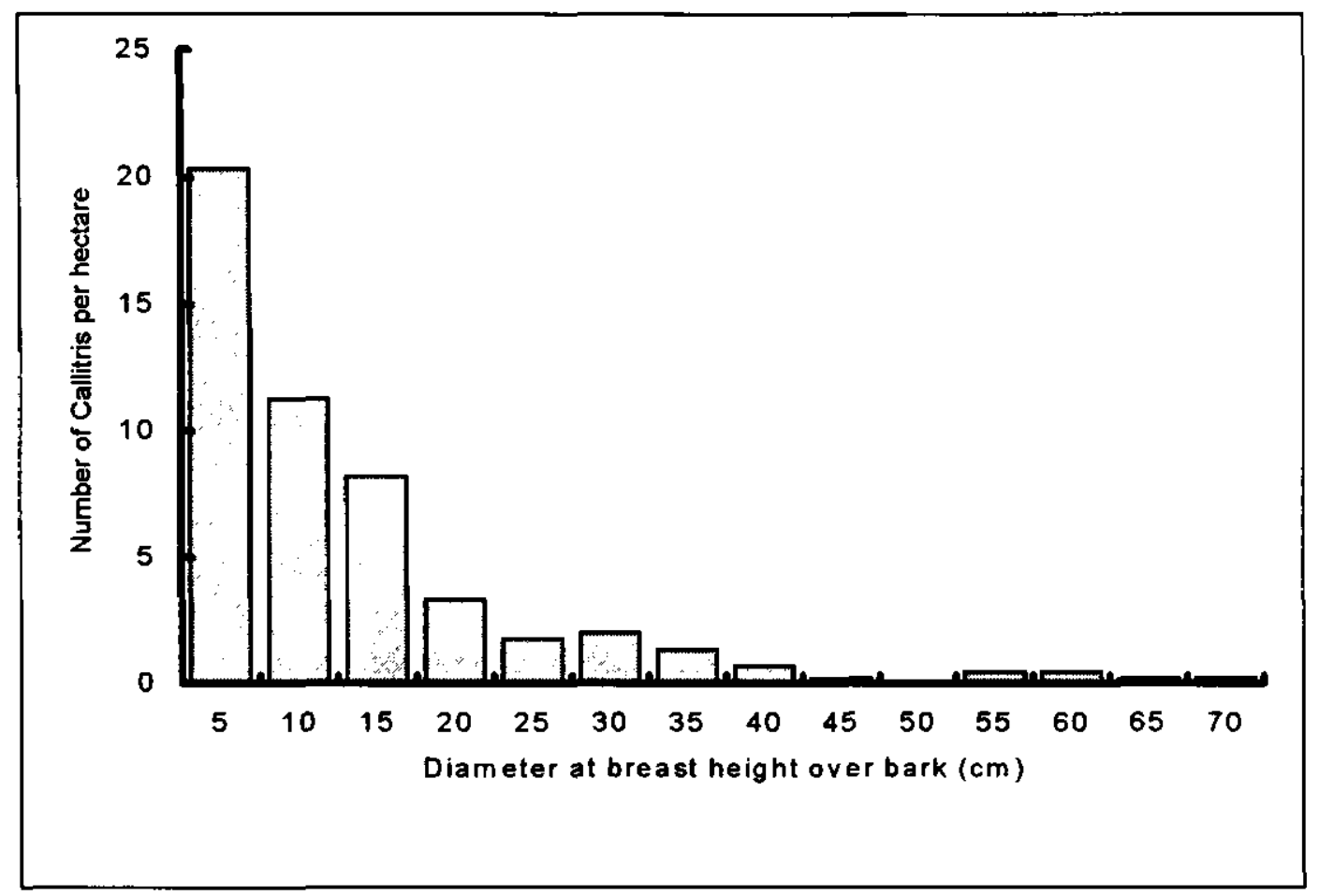

Figure 1. Projected Callitris size structure in the Callitris forest zone at Terrick Terrick National Park in 1860.

By assuming that all trees grew at the same growth rate, the size structure of the 1860s stand can be estimated (Figure 1). This graph shows that most Callitris were very small in 1860 , and few large trees appear to have been present. Thus, 86 percent of the 50 Callitris per hectare which existed in the 1860s were less than 20 centimetres diameter (at breast height over bark), and only 7 Callitris per hectare appear to have exceeded 20 centimetres diameter.

\section{Discussion}

Despite the need for a number of qualifications (see below), the above analyses expand our understanding of past changes in Callitris density at Terrick Terrick National Park in a number of ways. Before undertaking this study, virtually all available information from the reserve could be encapsulated in the following four very general statements. In 1863, the area was described as 'open forest land lightly timbered with Box [Eucalyptus species], 
Pine [Callitris glaucophylla], She Oak [Allocasuarina luehmannii or A. verticillata] and shrubbery...' (Willis 1863). According to local history, Callitris regenerated densely in the mid- to late-1800s (Morcom 1990; Parks Victoria 1997), although no accurate dates are available. Hardly any regeneration occurred from the 1880 s until the 1970 s, presumably due to heavy grazing by rabbits and stock (Parker and Lunt 2000). Dense regeneration from the late-1800s was progressively thinned and felled by the Forests Commission until harvesting ceased in the late-1980s.

The results from this ecological study support the accepted site history, but also provide new information, including quantitative estimates of changes in tree densities over the past 140 years and information on the size structure of the Callitris forest before the late-1800s recruitment pulse. However, these results should be interpreted as indicative estimates only, as stump studies are prone to two major problems based on the difficulties of estimating growth rates, and the inability to estimate how many stumps have disappeared.

The first problem arises because Callitris growth rates vary with stand densities, and trees in open stands grow considerably faster than those in dense stands. Unfortunately, real variations in growth rates will greatly influence estimates of past tree densities. However, since it is impossible to determine the real growth rate of every tree (or stump), in this study it was assumed that all trees grew at the same rate before they were cut. The extent to which this assumption is valid will depend upon the variability in local site conditions (which influence growth rates), and the intensity of silvicultural management.

Since the mid-1920s, Callitris stands at Terrick Terrick were repeatedly thinned by the Forests Commission to produce widely-spaced, 'plantationstyle' stands. Thinning is designed to hasten tree growth and to reduce the variability in growth rates which exists in unmanaged stands. Thus, intensive silvicultural management has helped to minimise problems arising from the assumption of uniform growth rates at Terrick Terrick National Park. More generally, because of this problem, stump studies may only be feasible in open Callitris woodlands, and the method may be prone to large errors in dense, locked stands.

The second problem arises since any stumps which were destroyed or decomposed before stump studies were undertaken will not contribute to the density estimates. This will lead to an under-estimate of real tree densities. Unfortunately, it is impossible to judge how many stumps have disappeared in the past. Stumps can easily be destroyed by fires, but fortunately no widespread fires have occurred at Terrick Terrick National Park since 
Callitris recruited densely in the late-1800s. More generally, stump studies may only be useful in sites which have not been burnt repeatedly this century.

How useful are stump studies likely to be in other Callitris forests? There is little doubt that stump studies have considerable potential to expand our knowledge of forest history (Curby 1997, Allen 1998). Depending upon past stand management, stumps have great potential to indicate minimum densities at various times in the past, and to indicate past tree size structures. However, the method is prone to under-estimate densities, and cannot provide useful estimates of likely maximum densities (largely because it is impossible to determine how many stumps may have disappeared before sampling). Since small stumps are likely to decompose rapidly, the method could lead to gross under-estimates of densities of small trees. This may render the method unsuitable in areas which once supported dense, locked stands of small, suppressed Callitris.

This study provides a useful site-specific case study in relation to the broader debates about past changes in tree densities (e.g. Ryan et al. 1995; Benson and Redpath 1997). Results show that a substantial regeneration pulse did occur in the late-1800s, as was known from local history. However, the results also indicate that the area was moderately well stocked before the major Callitris recruitment pulse, with approximately 50 Callitris per hectare plus other tree species. Surprisingly, however, the density of large Callitris (over 20 centimetres diameter) appears to have been very low (approximately 7 large Callitris per hectare). Since Callitris growth rates are strongly influenced by stand densities, the small trees that were abundant in 1860 could either have been young, or old and suppressed. Further studies on the spatial patterning of old stumps and of past fire dates based on fire scars could prove illuminating.

\section{References}

Allen, M. R. 1998. Forest bistory projects for State Forests of New South Wales. Case studies of three cypress pine forests on the Lacblan and Bogan River catchments, Forbes Forestry Distritt on Back Yamma, Euglo South and Strahom State Forests. Pennant Hills, NSW: State Forests of New South Wales.

Benson, J.S. and Redpath, P.A. 1997. The nature of pre-European native vegetation in south-eastem Australia: a critique of Ryan, D.G., Ryan, J.R and Starr, B.J. (1995). The Australian landscape - observations of explorers and early settlers. Cunninghamia 5: 285328.

Curby, P. 1997. Forest bistory project for State Forests of Nen South Wales. Narrandera study on Buckingbong, Gillenbah and Matong State Forests. Pennant Hills, NSW: State Forests of New South Wales. 
Morcom, L. 1990. Terrick Terrick State Park draft resources inventory and draft interim management guidelines. Bendigo, Victoria: Unpublished report, Department of Conservation, Forests and Lands.

Norris, E.H., Mitchell, P.B. and Hart, D.M. 1991. Vegetation changes in the Pilliga forests: a preliminary evaluation of the evidence. Vegetatio 91: 209-18.

Parker, D. and Lunt, I.D. 2000. Stand structure and recruitment patterns in Callitris Eucalyptus woodlands in Terick Terrick National Park, Victoria. Vittonian Naturalist 117: 207-13.

Parks Victoria. 1997. Terrick Terrick State Park Management Plan. Melbourne: Parks Victoria. Rolls, E. 1981. A million wild acres. Melboume: Thomas Nelson.

Ryan, D. G., Ryan, J. R, and Starr, B. J. 1995. The Australian landscape - observations of explorers and early settlers. Wagga Wagga, NSW: Murrumbidgee Catchment Management Committee.

Willis, G. 1863. Survey of the Northern Plains of Victoria (microfiche map). Melboume Central Plans Office. 


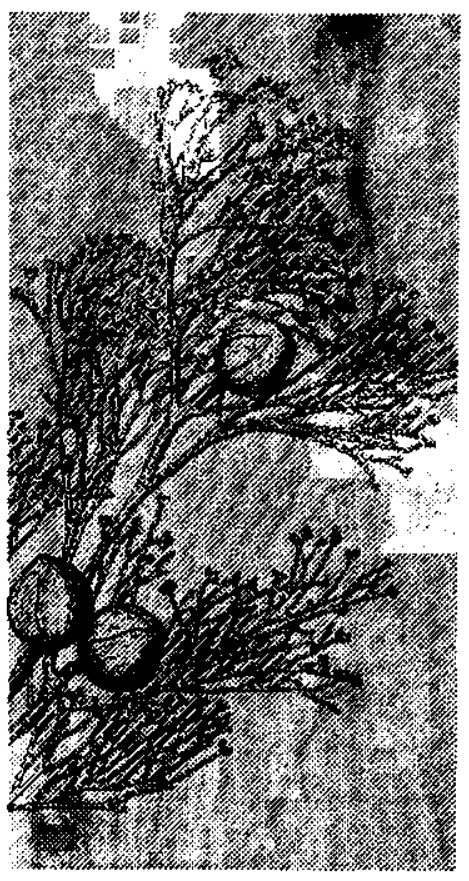

8

Stump count analysis of the pre-European Pilliga forests

\section{David Paull}

\section{Introduction}

Since the publication of Eric Rolls' A Million Wild Acres in 1981, the nature of the original forest communities of the Pilliga region has been the subject of much conjecture (e.g. Norris et al. 1991). Studies and speculations on the structure of the pre-European vegetation communities of the western woodland belt, have resulted in the acknowledgement, in some quarters, of the high level of structural and floristic variation that was once found within this extensive region. The caution with which one has to examine some historic evidence and traditionally held views about the nature of past vegetation patterns is discussed by Mitchell (1991), '...it is shown that the traditional wisdom surrounding these issues is partly erroneous and that folklore is in danger of becoming accepted fact'. Despite this, few studies have actually attempted to quantify historic tree densities, given the problems associated with interpreting stump count data. The earliest density assessments of ironbark were made in the late 1920 s, some time after extensive sleeper cutting had already commenced. Prior to the study reported here, stump counts had not been undertaken, to my knowledge.

Rolls wrote that the westem part of the Pilliga was dominated by a Callitris savannah at a density of four trees per hectare. This information is derived from a forester, John Ward, who in 1877 noted that this was the average density of large Callitris with about 25 young pine stems per hectare 
(Rolls 1981, p.183; van Kempen 1997). Ward did not note the densities of narrow-leaf red ironbark, Eucalyptus crebra, although Rolls contends that its density was the same or much higher. This view is contradicted by other observations such as made by one of the first squatters in the Pilliga, John Robertson, who 'admired the tall straight ironbark thick enough in parts to be a forest such as we hear of existing in other lands' (Rolls 1981, p.110). Rolls does not seem to differentiate between E. crebra and broad-leaf ironbark, E. fibrosa communities, which have clear differences in tree densities and growth forms.

In their evaluation of the historical evidence on the pre-European vegetation of the central west Croft et al. (1996) stated that the region was probably dominated by a variety of grassy or woodland dominated habitats.

\section{Study area and methods}

The study reported here was conducted to estimate the pre-European structure of the narrow-leaf ironbark dominated forest type of central Pilliga West State Forest. The study area lies within the Pilliga Outwash Province (Morgan and Terrey 1992) of the Brigalow Belt South Bioregion of New South Wales. It is a flat plain and is found on deep colluvial or alluvially derived sands. The study was undertaken between March and May 1999.

A plot-based stump count analysis was assisted by estimates of the average growth rates of the species and a knowledge of the logging history of the study area. Five compartments were selected in the north/central area of the forest, none of which had been logged since 1991. Average growth rates for each species were used to extrapolate the size of each tree in 1910, assuming no tree had been cut down after 1991 .

It is stated in the Pilliga Management Plan (Forestry Commission 1986a) that the average diameter growth rate for E. crebra is 2 millimetres per year (range 0-7 millimetres per year). This study assumed the same average growth. It represents the growth rate across all size classes of trees, and while younger trees will have quicker growth rates, up to 7 millimetres per year, older trees, such as the ones dealt with in this paper, may in fact have slower ones.

Cypress pine has a much more variable growth rate than ironbark, with spurts associated with years of good rainfall. Growth rates are also affected by tree density and 'site quality', better soils yielding annual diameter increments of 6-7 millimetres at tree densities of over 100 stems per hectare. Low site quality sites in the Forbes district were found to yield increments of 1-3 millimetres in diameter (Forestry Commission 1986b). In the Pilliga, the only 
published growth information states that this species has an average growth range of 1-3 millimetres a year (Forestry Commission 1986a). For the most part, soil quality in ironbark-dominated areas can be assumed to be poor. So for the purposes of this study, the median value of 2 millimetres increment was assumed. As for ironbarks, growth in young trees may be rapid, though growth in old trees, over 50 centimetres in diameter, is more than likely to be at or below the lower part of the published range.

Twenty, one-hectare plots were selected by taking the mid-point at each side of the selected compartment and moving in 100 metres off the road. The locations of some of the plots were adjusted if they fell within patches of Pilliga box, E. pilligaensis. Allocasuarina leubmannii were not counted as part of this study as growth rates for this species are not known and it is generally an understorey species. In each plot, every stump, living and dead ironbark tree of 64 centimetres and over was counted. The assumed average growth rate was extrapolated back from a tree of 64 centimetres in diameter in 1999 to estimate that it would have been less than 50 centimetres in diameter in 1910. It was found that most stumps in the plots were of considerable age and so this may be a conservative estimate of the size of the average ironbark tree in 1910. Few burnt out stumps were encountered but were also counted if they were complete enough for a reliable estimate of their diameter to be made. The diameter of the stumps was measured at a height of 60 centimetres above the ground.

Virtually all cypress stumps of any size over 50 centimetres diameter were found to be very old, probably dating back to the 1950 s and earlier. It is noted that the peak cypress extraction period in the area was during the 1940 s, so that most of the large cypress stems had already been removed by the 1950s (Forestry Commission 1986a). Some leeway was thus given to the size of cypress stumps that were included in the counts, with anything 60 centimetres and over being included in the analysis to give an extrapolated density of stems 50 centimetres and over in 1910. Dead and living cypress stems of this size were also counted and added to the plot tallies.

\section{Results}

Results are presented in Table 1. There are a number of trends evident in the data. First is that in areas where historic densities of cypress were highest, ironbark densities were lowest and vice versa. However even in these areas, there were found to be more ironbarks per hectare than cypress pines. The heights of all living trees that were measured (both species) varied between 


\section{Perfumed Pineries}

about 25 and 30 metres high. Some very large ironbark stumps (over 100 centimetres in diameter) probably once had even taller canopies.

Table 1: Number of stumps, dead and living trees

Figures in italics show living trees struck by lightning

\begin{tabular}{|c|c|c|c|c|c|c|c|c|c|c|}
\hline \multirow[t]{2}{*}{ Plot } & \multicolumn{5}{|c|}{ Narrow leaf ironbark } & \multicolumn{4}{|c|}{ Cypress pine } & \multirow[t]{2}{*}{ Total } \\
\hline & Stumps & Live & $\begin{array}{l}\text { rees } \\
\text { truck }\end{array}$ & $\begin{array}{r}\text { Dead } \\
\text { trees }\end{array}$ & $\begin{array}{l}\text { Sub- } \\
\text { total }\end{array}$ & Stumps & $\begin{array}{l}\text { Live } \\
\text { tree }\end{array}$ & $\begin{array}{r}\text { Dead } \\
\text { trees }\end{array}$ & $\begin{array}{l}\text { Sub- } \\
\text { total }\end{array}$ & \\
\hline 1 & 10 & 1 & & 3 & 14 & 6 & 1 & 2 & 9 & 23 \\
\hline 2 & 10 & 3 & 1 & 2 & 15 & 6 & 1 & 1 & 8 & 23 \\
\hline 3 & 10 & 1 & & 4 & 15 & 5 & 0 & 2 & 7 & 22 \\
\hline 4 & 12 & 2 & & 2 & 16 & 6 & 1 & 0 & 7 & 23 \\
\hline 5 & 16 & 1 & & 1 & 18 & 5 & 0 & 1 & 6 & 24 \\
\hline 6 & 17 & 2 & 1 & 2 & 21 & 6 & 0 & 0 & 6 & 27 \\
\hline 7 & 20 & 3 & 1 & 2 & 25 & 5 & 0 & 1 & 6 & 31 \\
\hline 8 & 19 & 2 & & 4 & 25 & 5 & 0 & 1 & 6 & 31 \\
\hline 9 & 18 & 4 & 1 & 3 & 25 & 5 & 0 & 0 & 5 & 30 \\
\hline 10 & 23 & 1 & & 3 & 27 & 3 & 0 & 2 & 5 & 32 \\
\hline 11 & 20 & 5 & 1 & 2 & 27 & 4 & 0 & 1 & 5 & 32 \\
\hline 12 & 23 & 4 & 1 & 1 & 28 & 4 & 0 & 0 & 4 & 32 \\
\hline 13 & 22 & 3 & & 4 & 29 & 3 & 0 & 1 & 4 & 33 \\
\hline 14 & 23 & 4 & 1 & 2 & 29 & 3 & 0 & 1 & 4 & 33 \\
\hline 15 & 22 & 6 & 1 & 2 & 29 & 3 & 0 & 0 & 3 & 32 \\
\hline 16 & 19 & 5 & 1 & 5 & 29 & 1 & 0 & 2 & 3 & 32 \\
\hline 17 & 18 & 10 & 3 & 2 & 30 & 2 & 0 & 1 & 3 & 33 \\
\hline 18 & 18 & 9 & 2 & 3 & 30 & 1 & 0 & 1 & 2 & 32 \\
\hline 19 & 17 & 10 & 2 & 4 & 31 & 2 & 0 & 0 & 2 & 33 \\
\hline 20 & 17 & 12 & 3 & 2 & 31 & 1 & 0 & 0 & 1 & 32 \\
\hline Total & 354 & 88 & 22 & 53 & 494 & 76 & 3 & 17 & 96 & 590 \\
\hline Mean & 17.7 & 4.4 & 1.1 & 2.6 & 24.7 & 3.8 & 0.2 & 0.8 & 4.8 & 29.5 \\
\hline
\end{tabular}

\section{Discussion}

Narrow-leaf ironbark is but one of the ironbark associations in the Pilliga. The historic evidence supports the view that by and large it had a fairly open understorey, dominated by grasses. Observations by William Head for the Kiambir Pastoral Lease in $\mathbf{1 8 8 5}$ state, 'Ironbark forest on south bank of creek and on both sides of Stony Plains boundary very fair when grassed' (van Kempen 1997). Maiden and Cleland (1920) write that in ironbark forest, 
'there is not much undergrowth as a rule, though thickets of Acacia conferta may occur'.

Work recently undertaken jointly by State Forests of New South Wales and the National Parks and Wildlife Service identifies this community as an 'eastern grassy woodland', although no ironbark plots were measured in the Pilliga West (Binns and Beckers, Chapter 13). The shrubs occurring in the Pilliga West community include mostly taller shrubs and small trees of a variety of species, including Acacia, Dodonea, Eremophila, Geijera, Santalum along with Alectyon oleifolius and wild Apricot (Pittosporum phylliraeioides).

Pre-European densities of large narrow-leaf ironbark trees probably showed some variation, although it probably was a true forest type, characterised by the highest density of big, mature trees when compared to other types in the Pilliga. This is particularly true of the central area of Pilliga West State Forest where the stump count analysis was undertaken, although it is likely that this forest type had similar densities and growth form throughout its distribution in both western, northern and central areas of the Pilliga.

By 1908, before the Forestry Commission was established, a lot of timber had already been taken as sleepers, particularly from the north, near Narrabri, where 'all the good sleeper trees were gone' (van Kempen 1997). However at the same time it is also stated that, 'the best part of the Pilliga Scrub, between Cubbo Station and Baradine, on both sides of Dubbo (Baradine) Creek has not yet been touched' (van Kempen 1997).

Inspector Pope of the Forestry Commission described the area west of the Baradine Creek as 'consistently good and valuable' (van Kempen 1997, p.52). This was endorsed by de Beuzeville in 1916 who described the western Pilliga thus:

there exists in the Western Pilliga an ideal forest area, practically in its virgin state, which is a very valuable asset to the Department controlling it. We have (1) excellent forest of Cal. glauca occupying about onethird of the area. (2) a similar forest of E. crebra of about the same extent. (3) an excellent area of grazing and edible shrub land of perhaps about the same area, and (4) an enormous forest of immature C. glauca, occupying about three-fourths of the total area of the combined types (van Kempen 1997, p.53).

Cypress regrowth was obviously already extensive, despite the appearance of rabbits some time before (van Kempen 1997). These estimates clearly show that the Pilliga West was extensively covered with ironbark-dominated forest at this time. No mention is made of the extensive area of box woodland in the north of the State Forest, or the red gum in the west, both of which now occupy over 20 percent of the entire forest. As box or red gum 
were not considered commercial species, it is likely that the Callitris forest mentioned is partly from these areas.

The Commission established a method for estimating tree densities, known as the 10 percent strip assessment, although no information was available for the Pilliga West until some time later. Strip assessments were undertaken in Pilliga West by District Forester Burrow in 1923 who estimated that there were 12.5 cypress pine trees per hectare of 30 centimetres and over and 7.2 ironbark trees 50 centimetres and over. Exactly where these estimates were taken is not clear (van Kempen 1997). In 1929, B. Preistman conducted strip assessments of the Ginee section of Pilliga West, just to the east of the Pilliga/Coonamble Road and found 20.4 pines and 5.6 ironbarks per hectare over 25 centimetres diameter. He noted that the area had already been heavily exploited for timber. In an adjacent compartment to the west of the road, he found 4 ironbarks of all sizes and 9 pines over 25 centimetres per hectare. These assessments did not include stumps. Van Kempen (1997) did not report any assessments from the central area of Pilliga West where the present stump count analysis was undertaken.

Work undertaken in the box-ironbark forests of Victoria, show a comparable pre-European density of eucalypts. In a study conducted by the Arthur Rylah Institute (Soderquist et al. 1999) and the Forests Commission of Victoria (Newsome 1961), the density of large mature eucalypts (over 60 centimetres in diameter at breast height) was found to be around 20 per hectare. Lunt (1997) found a density of mature trees in box woodland in Victoria on average to be 13.65 per hectare. Benson and Redpath (1997) estimate that the forests of the Pilliga would have carried about 30 mature trees per hectare.

Disturbance in the Victorian forests has been so widespread that only one 2 hectare patch of forest was identified as being 'old-growth'. Roughly 85 percent of the number of large stems had been removed, while in this study it is estimated that over 90 percent of the original number of large, mature ironbark stems have been removed since management by the Forestry Commission of New South Wales commenced. Current density estimates of this species derived from recent data collected by State Forests (State Forests 2000) put the average density of stems greater than 50 centimetres diameter at 2 per hectare. For the large cypress pine, the situation is even worse, with only 3 living stems over 60 centimetres found in the 20 plots, from an estimated 80 which would have been in the immediately preEuropean forest in the same area.

The results of this stump count analysis outlined here show that there was some natural variation in the relative numbers of pine and ironbark 
within the study area from plot to plot, although the highest densities of large pine ( 9 per hectare) were still outnumbered by large ironbarks in the same plots.

An idea of the pre-European structure of the narrow-leaf ironbark forest can now be assessed using contemporary vegetation classification schemes. The one used here (AUSLIG 1990) classifies areas with trees at about 30 meters tall, occurring at densities of about 30 per hectare, as a true forest, typically, dry open forest. Such a forest is generally typified as having a foliage cover of over 30 percent and a more open understorey, largely because of this high foliage cover.

\section{Acknowledgments}

I would like to thank Todd Soderquist, Matthew Cameron, Ian Lunt, Mike Atkinson and Dick Curtin for their helpful comments.

\section{References}

AUSLIG, 1990. Vegetation. Atlas of Australian resourres. $3^{\text {rd }}$ Series. Vol. 6. Canberra: Auslig.

Benson, J.S. and Redpath, P.A., 1997. The nature of pre-European native vegetation in south-eastern Australia: a critique of Ryan, D.G., Ryan, J.R. and Starr, B.J., 1995. The Australian Landscape - Observations of explorers and early settlers. Cunninghamiana 5(2): 285329.

Croft, M., Goldney, D. and Cardale, S., 1996. Forest and woodland cover in the central westem region of New South Wales prior to European settlement. Bathurst NSW: Remnant Woodland Ecology Program, Environmental Studies Unit, Charles Sturt University.

Forestry Commission, 1986a. Management Plan for Forestry Operations in the Pilliga Management Area.

Forestry Commission, 1986b. Diameter growth of mature Cypress Pine in the Forbes District.

Lunt, I.A., 1997. Tree densities last century on the lowland Gippsland Plain, Victoria. Australian Geographic Studies 35(3): 342-48.

Maiden, J.H. and Cleland, J.B. 1920. The botany of the Pilliga Scrub, NSW. Forestry Commission of NSW.

Mitchell, P.B., 1991. Historical perspectives on some vegetation and soil changes in semiarid New South Wales. Vegetatio 91: 169-82.

Morgan, G. and Terrey, J., 1992. Nature conservation in western New South Wales. Sydney: National Parks Association of NSW.

Newsome, L.A., 1961. The Box-Ironbark forests of Victoria, Australia. The Eighth British Commonwealth Forestry Conference, Melbourme.

Norris, E.H., Mitchell, P.B. and Hart, D.M., 1991. Vegetation changes in the Pilliga forests: a preliminary evaluation of the evidence. Vegetatio 91: 209-18. 
Rolls, E., 1981. A million wild acres. Melboume: Penguin Books.

Soderquist, T, Lumsden, $L$ and Bennett, A. 1999. Size does matter. Large old trees in BoxIronbark Forests. Wildlife in box-imnbark forests, linking research and biodiversity manugement 5 . Heidelberg, Vic: Arthur Rylah Institute for Environmental Research.

State Forests of NSW, 2000. Strategic Inventory: Draft Summary Report for the sections of Pilliga, Gilgandra and Dubbo Management areas which fall within the Brigalow Belt South Bioregion. Project undertaken as part of Stage 1 of the South Brigalow Assessment, Westem Regional Assessment.

van Kempen, E., 1997. A bistory of the Pilliga sppress pine forests. Dubbo: State Forests of NSW. 


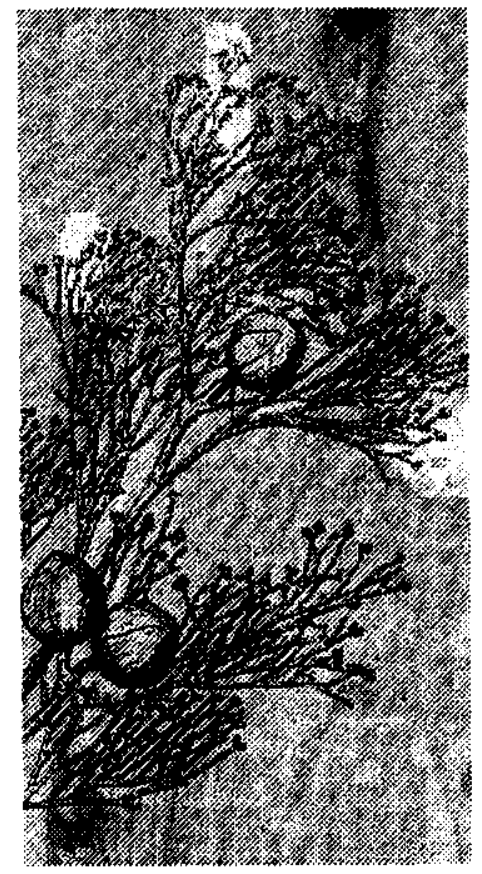

9

\section{Soil, vegetation and landform in Pilliga East State Forest}

Geoff Humphreys, Elizabeth Norris, Paul Hesse, Diane Hart, Peter Mitchell, Peter Walsh and Russell Field

\section{Introduction}

White cypress, Callitris glaucopbylla, is the most widely distributed species of the genus covering a broad swathe of country in the $350-700 \mathrm{~mm}$ rainfall zone from central Queensland through New South Wales with isolated patches in other mainland states. It is the most common tree in the Pilliga State Forest where it occurs under a variety of edaphic conditions and topography within a 500-700 mm rainfall zone (Jensen 1914, Hallsworth and Waring 1964, Mitchell and Rundle 1982). However, the dominance of white cypress varies within the forest and this suggests that other limiting factors assume dominance. This preliminary study examines the effects of other environmental attributes in the Pilliga East State Forest where European influences on the vegetation are thought to have been minimal (Norris et al. 1991). An area east of Etoo Creek to Ironbark Crossing Road, and north from Pilliga Forest Way to Dunwerian Road encompassing about 4000 hectares is where we have focussed our recent research (Hart 1992 and 1995, Norris 1996, Humphreys et al. 1997, Hesse et al. 1998, Hesse 2000). 
Table 1. Communities recognized in Pilliga East State Forest

\begin{tabular}{|c|c|c|c|}
\hline $\begin{array}{l}\text { Community } \\
\text { name as used in } \\
\text { this chapter }\end{array}$ & $\begin{array}{l}\text { Structure } \\
\text { (as per Specht } \\
1970)\end{array}$ & Key species & $\begin{array}{l}\text { Presence of } \\
\text { white } \\
\text { cypress }\end{array}$ \\
\hline Broom & $\begin{array}{l}\text { Closed heath to } \\
\text { tall shrubland }\end{array}$ & $\begin{array}{l}\text { Melaleuca uncinata, Calytrix } \\
\text { tetragona, Micromyrtus sessilis }\end{array}$ & minor \\
\hline Mallee & Woodland & Eucalypts viridis & present \\
\hline Belah & Open forest & Casuarina cristata & very minor \\
\hline Mixed forest I & $\begin{array}{l}\text { Open forest, } \\
\text { woodland }\end{array}$ & $\begin{array}{l}\text { Eucalyptus crebra, } \\
\text { Callitris glaucopbylla }\end{array}$ & abundant \\
\hline Mixed forest II & Open forest & E. crebra, C. glaucopbylla & abundant \\
\hline Mixed forest III & $\begin{array}{l}\text { Open forest } \\
\text { and woodland } \\
\text { on terraces and } \\
\text { alluvium }\end{array}$ & $\begin{array}{l}\text { E. crebra, C. glaucopbylla, } \\
\text { E. blakelyi }\end{array}$ & abundant \\
\hline Mixed forest IV & $\begin{array}{l}\text { Open forest } \\
\text { and w'land on } \\
\text { stony land }\end{array}$ & E. crebra, C. glaucopbylla & abundant \\
\hline Mixed forest $\mathrm{V}$ & Open forest & E. crebra, Acacia neriifolia & common \\
\hline Mixed forest VI & $\begin{array}{l}\text { Open forest } \\
\text { and woodland }\end{array}$ & $\begin{array}{l}\text { E. crebra, C. glaucopbylla, } \\
\text { Allocasuarina Leuhmannii }\end{array}$ & abundant \\
\hline Box Forest & $\begin{array}{l}\text { Open forest, } \\
\text { woodland }\end{array}$ & C. glaucopbylla, E. pilligaensis & abundant \\
\hline Sand Monkey I & $\begin{array}{l}\text { Open } \\
\text { woodland }\end{array}$ & C. glaucopbylla, E. chloroclada & common \\
\hline Sand Monkey II & $\begin{array}{l}\text { Open } \\
\text { woodland }\end{array}$ & $\begin{array}{l}\text { E. crebra, C. glaucopbylla, } \\
\text { Angophora floribunda, } \\
\text { Corymbia tackypbloia }\end{array}$ & common \\
\hline
\end{tabular}

\section{Methods}

The main analysis involved ascertaining the range of soil conditions as well as the main soil types that support distinct vegetation associations. Information on soil features was placed in a database and linked to the vegetation communities (Norris 1996) and to the landform unit (Hesse 2000). At this time only a preliminary analysis has been undertaken focussing on a few diagnostic properties: general textural trend (uniform, gradational and 
texture contrast or duplex soils of Northcote 1979), field $\mathrm{pH}$, topsoil depth in texture contrast soils, and structure in clayey materials including subsoils.

Standard soil chemical properties were undertaken at Hill Laboratory, New Zealand and mineralogy of the under $2 \mathrm{~mm}$ fraction was determined by X-ray diffraction at CSIRO Land and Water. Linear shrinkage was performed as per current engineering standards. Vegetation associations follow the structural classification of Specht (1970) and taxonomy utilises the most recent revisions as adopted by the Royal Botanic Gardens, Sydney. Landform units are based on distinguishing erosional from depositional landscape elements in which the former is largely bedrock controlled (Hesse 2000). Gravimetric soil moisture was sampled seven times over a 21-month period from nineteen sites at $10 \mathrm{~cm}$ intervals (Norris 1996). For this paper these data were averaged in terms of two depth classes (topsoil mostly 10-50 $\mathrm{cm}$ and subsoil deeper than $50 \mathrm{~cm}$ ) on a per vegetation type basis.

\section{Results and discussion}

Floristically and structurally the vegetation in Pilliga East State Forest comprises four main groups: broom, mallee, belah and a eucalypt-cypress woodland to forest. The first three comprise distinct communities with sharp boundaries. The latter grouping is much more variable and several subtypes can be distinguished, usually on the basis of some combination of change in dominance of key tree taxa and/or the appearance of a particular eucalypt other than Eucalyptus crebra or other non-cypress tree genera. Hence, across the study area of about 4000 hectares, eleven communities are recognized. Another unit, Mixed Forest IV (mixed forest on stony ridges), occurs nearby.

White cypress occurs in all communities identified though it is less common in two: the Belah and Broom. Collectively, the distribution patterns imply that white cypress is well suited to the area $(500-600 \mathrm{~mm}$ on average but highly variable rainfall) as is expected from the known distribution pattern of this species. Its less than common occurrence in two communities suggests that another factor is involved and this issue is pursued next.

The approach adopted in this study is to compare the properties of soil types that white cypress is commonly associated with, to those where it is rare. This is undertaken on a soil type basis first, thence via key soil properties (Table 2). 
Table 2. Selected soil properties

\begin{tabular}{|c|c|c|c|c|c|c|}
\hline \multirow{3}{*}{ Property } & \multicolumn{6}{|c|}{ General soil group } \\
\hline & \multicolumn{2}{|c|}{$\begin{array}{l}\text { Deep sand } \\
(2-4 \mathrm{~m})\end{array}$} & \multicolumn{2}{|c|}{$\begin{array}{c}\text { Texture contrast } \\
\text { soils } \\
\text { (topsoil } 10-60+\mathrm{cm} \text { ) }\end{array}$} & \multicolumn{2}{|c|}{$\begin{array}{c}\text { Deep clay } \\
(>2 \mathrm{~m})\end{array}$} \\
\hline & $\begin{array}{c}\text { Sand } \\
\text { Monkey }\end{array}$ & Broom & Mallee & $\begin{array}{l}\text { Mixed } \\
\text { forest }\end{array}$ & $\begin{array}{l}\text { Box } \\
\text { forest }\end{array}$ & Belah \\
\hline Topsoil pH & $5.5-6$ & $4.5-6$ & $5-5.5$ & $5.5-7$ & $5-7$ & $5.5-7$ \\
\hline Subsoil $\mathrm{pH}$ & $6-6.5$ & $5-6.5$ & $5-6$ & $5-9.5$ & $6.5-9$ & $8-10$ \\
\hline Soluble salts $(\%)$ & $<0.1$ & $<0.1$ & 0.28 & $<0.1$ & 0.11 & 0.21 \\
\hline $\begin{array}{l}\text { Mg:Ca ratio } \\
\text { (subsoil) }\end{array}$ & $0.1-0.7$ & 4.8 & $20-33$ & $2.9-4.5$ & $1-7$ & 1 \\
\hline Carbonate $(\%)$ & 0 & 0 & 0 & 0 & 2.7 & 4 \\
\hline $\begin{array}{l}\text { Smectite: } \\
\text { kaolinite ratio }\end{array}$ & nd & 0.25 & 1.3 & nd & 1 & 4 \\
\hline $\begin{array}{l}\text { Linear shrinkage } \\
(\%)\end{array}$ & nd & 10 & 10 & 10 & 10 & $10-20$ \\
\hline $\begin{array}{l}\text { Soil Order } \\
\text { (Isbell 1996) }\end{array}$ & Tenosol & Kurosol & Kurosol & $\begin{array}{l}\text { Kurosol } \\
\text { or } \\
\text { Sodosol }\end{array}$ & $\begin{array}{l}\text { Kurosol } \\
\text { or } \\
\text { Sodosol }\end{array}$ & Ventosol \\
\hline
\end{tabular}

Note: $\mathrm{nd}=$ not determined

To assist this analysis the vegetation communities are simplified to six groupings of which the Broom, Mallee, Belah and Box remain unchanged. The Sand Monkey (ancient creek channels) group includes both Sand Monkey communities whereas the Mixed Forest group is largely based on types I, II and VI as defined in Table 1. These groupings are treated separately with their associated soil type (Table 2). The only soil type on which white cypress is exclusively rare is the Vertosol (Grey Clay in older Australian literature cf. Stace et al. 1968). Clearly, there is a major contrast between Vertosols and the deep infertile sands of palaeochannels and dunes of the Tenosols (Earthy Sands), and in this situation the relative presence/absence of white cypress is not surprising. In contrast, the other community where white cypress is less common, Broom, is found on Kurosols (Solodized Solonetz), which is a texture contrast soil, but the same general soil type also occurs where $C$. glaucophylla and E. crebra are common. In the Pilliga East State Forest the Kurosols are morphologically similar to the Sodosols (Soloth) and are noted for their poor fertility and also for a distinctive but thin hardpan layer that sits over large columnar or domed peds (natural soil aggregates). 


\section{(a) topsoil}
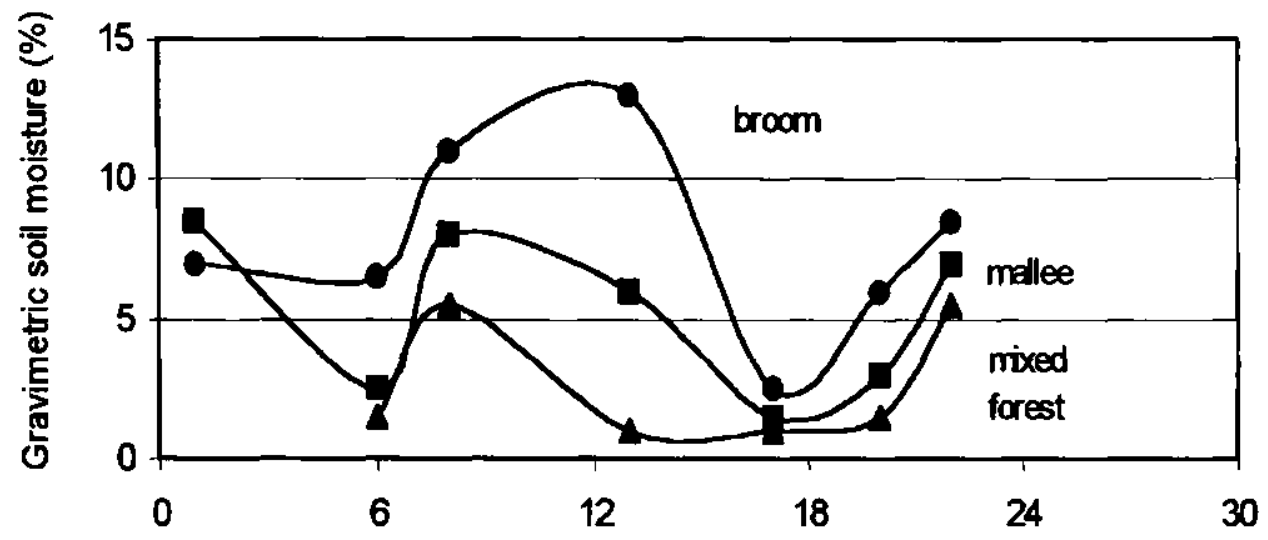

Time (manths fram Sept 1987)

(b) subsoil $>50 \mathrm{~cm}$

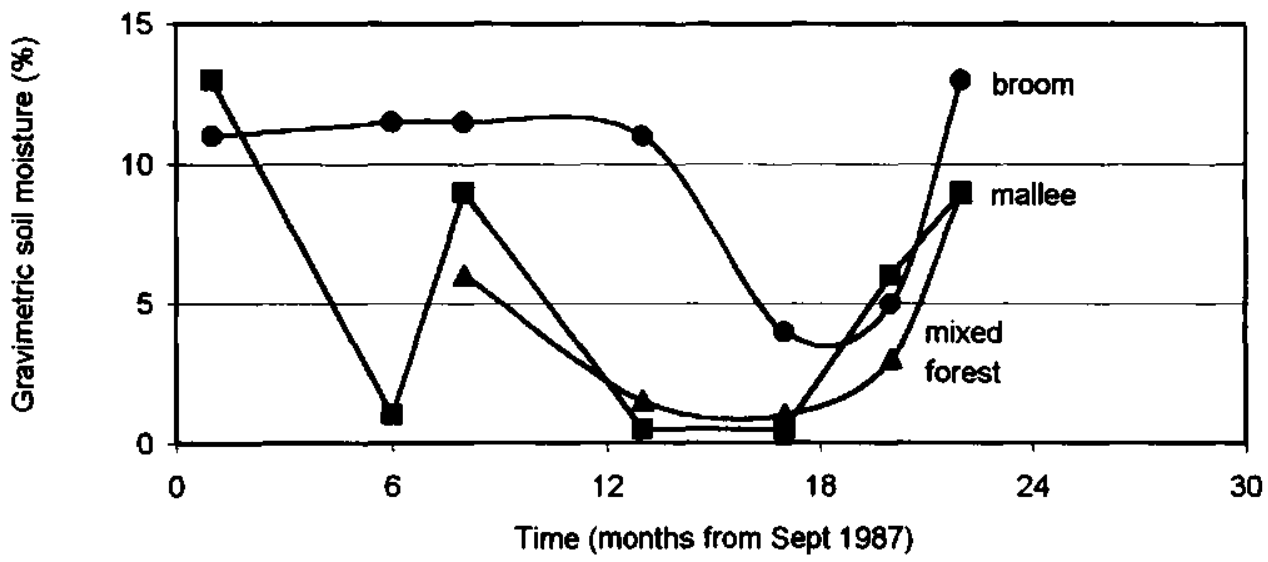

Figure 1. Soil moisture of (a) topsoil, and (b) subsoil.

An even more confusing pattern emerges when various soil properties are examined. White cypress clearly grows well under a wide range of soil conditions but the cypress-deficient situations generally encompass the extreme of the range of values recorded such as the lowest and the highest $\mathrm{pH}$. Nevertheless, the pattern is not clear cut especially among the texture contrast soils, Kurosols and Sodosols, which are the most widespread soil types in the area. On this basis other factors may be more important and one of these is considered next. 


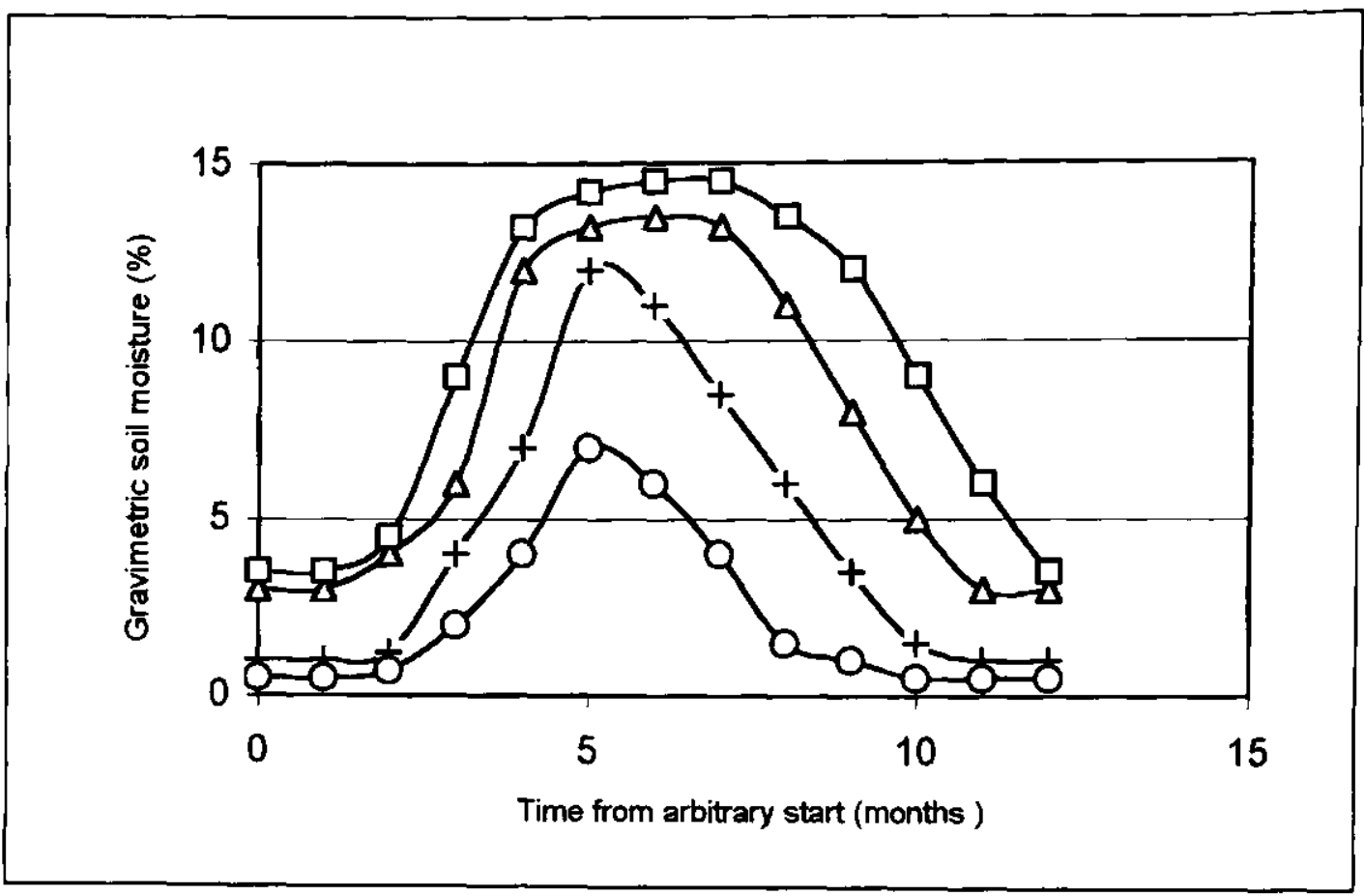

Figure 2. Hypothesised generalized wetting and drying cycles of whole soil in different vegetation communities. This figure relates to a wetting-up event and subsequent drying-out which can occur at any time. $\square$ Belah, $\Delta$ Broom, + Mallee \& Mixed Forest, $O$ Sand Monkey

\section{Relationship between communities and soil permeability/water holding capacity}

A common field observation indicates that when the texture contrast soils (Kurosols and Sodosols) are wet there is a dramatic decrease in mechanical strength. In this situation the almost ubiquitous, thin (mostly $<5 \mathrm{~cm}$ thick) hardpan layer (fragipan) that sits atop the clayey subsoil has the appearance of very sloppy porridge when wet (compared to brick hard when dry) so that the overlying sandy topsoil is hardly supported.

The soil moisture study showed that the soil in the Broom is generally wetter than in the other communities and this holds true for the sandy topsoil (Figure 1a) and clayey subsoil (Figure 1b) and during phases of high soil moisture (rainy periods) and during drought conditions. During a drought phase the Broom site dried out much more slowly, lagging by six months. A similar effect is evident in the topsoil between the Broom and Mixed Forest whereas the lag with Mallee is much briefer. In contrast, the wetting-up of the soils under all communities is rapid and very similar. These trends are used to hypothesise wetting and drying trends for the 
other major soil types viz. the Tenosol and Vertosol (Table 2). A rapid rate of wetting-up and a slower rate of drying-out are suggested for all sites as was indicated in Figures 1a and b. A higher maximum water content can be expected at the Belah site because of the shrink-swell potential (linear shrinkage) of this clayey soil. By the same reasoning, the sandy soil of the Sand Monkey sites has much reduced water-holding capacity.

This study strongly indicates that the Belah and Broom are generally wetter than the other sites, and that the less common occurrence of white cypress on these sites is probably related to adverse conditions for root growth for this species.

\section{Conclusions}

In the Pilliga East State Forest white cypress occurs on a wide range of landforms, both erosional and depositional, and on a variety of Texture Contrast Soils and Deep Sands spanning a wide range of chemical properties. The Callitris avoids moist or wet sites such as the Broom and Belah which are also sites where the extreme values of various soil chemical properties occur. Hence, this combination may operate as a major limitation in an environment where the climate appears to be highly suited to white cypress.

\section{References}

Hallsworth, E. G. and Waring, H. D. 1964. Studies in pedogenesis in New South Wales. VIII. An alternative hypothesis for the formation of the solodized-solonetz of the Pilliga district. Journal of Soil Science. 15: 158-77.

Hart, D.M. 1992. A field appraisal of the role of plant opal in the Australian environment. Unpubl. PhD Thesis, Macquarie University.

Hart, D. M. 1995. Litterfall and decomposition in the Pilliga State Forests, New South Wales, Australia. Australian Journal of Ecology. 20: 19-25.

Hesse, P.P. 2000. Geomorphology of the Goonoo and Pilliga Forests, Brigalow Belt South Bioregion. Unpublished report to National Parks and Wildlife Services of NSW.

Hesse, P.P., Townsend, F.N., Humphreys, G.S. and Kamper, S. 1998. Dust accession rates over the Late Pleistocene in Northern NSW: the potential for the formation of aeolian mantles and reworking within the landscape. Symposium on Aeolian Dust: Implications for Australian Mineral Exploration and Environmental Management, Canberra: Cooperative Research Centre for Landscape Evolution and Mineral Exploration.

Humphreys, G.S., Kamper, S., Hart, D.M. and Hesse, P.P. 1997. Origin and post depositional modification of Quaternary sand bodies in the Pilliga: a marginal semi-arid site. Quatemary Deserts and Climatic Change Conference, 30 June - 3 July, 1997, Conference Proceedings. School of Geosciences, University of Wollongong. 
Isbell, R.F. 1996. The Australian soil classification. Austratian Soil and Land Survey bandbook. Australia: CSIRO.

Jensen, H.I. 1914. The agricultural prospects of the Pilliga Scrub. NSW Farmers' Bulletin 54. NSW Department of Agriculture.

Mitchell, P.B., Rundle, A.S. and Students. 1982. Land systems of the Pilliga Region, N.S.W., Unpubl. Report to the New South Wales National Parks and Wildlife Service, Macquarie University.

Norris E.H. 1996. A study of the soil and vegetation pattems within part of the Pilliga forests, and an evaluation of the impact of European settlement on the vegetation. Unpubl. MSc thesis, Macquarie University.

Norris, E.H., Mitchell, P.B. and Hart, D.M. 1991. Vegetation changes in the Pilliga forests: A preliminary evaluation of the evidence. In A. Henderson-Sellers and A. J. Pitman, (eds), Vegetation and climate interactions in semi-arid areas. The Netherlands: Kluwer Academic Publications.

Northcote, K.H. 1979. A factual key for the recognition of Australian soils. CSIRO and Rellim Technical Publications.

Stace, H.C.T., Hubble, G.D., Brewer, R, Northcote, K.H., Sleeman, J.R, Mulcahy, M.J. and Hallsworth, E.C. 1968. A bandbook of Australian soils. Glenside, South Australia: Rellim Technical Publications.

Specht, R.L. 1970. Vegetation. In Leeper, G.W. (ed) $4^{\text {th }}$ edn. Melboume: CSIRO and Melboume University Press 


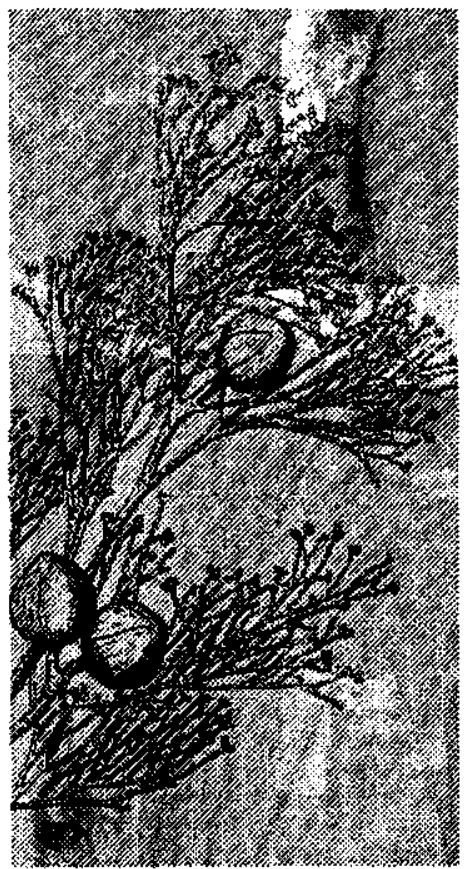

10

Pilliga landscapes,

Quaternary environment

and geomorphology

Paul Hesse

and Geoff Humphreys

The nearly continuous blanket of cypress pine and ironbark of the Pilliga forests gives the impression of great uniformity and permanence of the landscape, however these are false impressions. The present forests span two distinct landscapes, the Pilliga Sandstone hills and the Pilliga outwash plain, which reveal a surprisingly dynamic history over the last 100000 years or more of the Quaternary period.

\section{Pilliga Sandstone hills}

In the south and east the forest drapes a hilly landscape developed on the Pilliga Sandstone Formation (Figure 1). The creeks and slopes climb toward the boundaries of the forest where steep rocky slopes and gorges dissect a gentle northward dipping sandstone plateau. On the plateau and on the gentler hills in the north, deeper soils have weathered from the bedrock and outcrop is extremely rare.

The Pilliga Sandstone and underlying Purlawaugh Formation have a gentle northward dip through the central Pilliga, becoming a WNW dip on the eastern margin. The deep valleys at the head of Baradine Creek and Bohena Creek cut below the base of the Pilliga sandstone and expose the 
Purlawaugh Formation. The prominent cliff-forming member of the Pilliga Sandstone is exposed spectacularly in cliffs around the Warrumbungles and there are numerous springs marking the base of the Pilliga Sandstone along Dandry Creek, Baradine Creek and Wittenbra Creek and along the eastern boundary of the Pilliga East Forest.

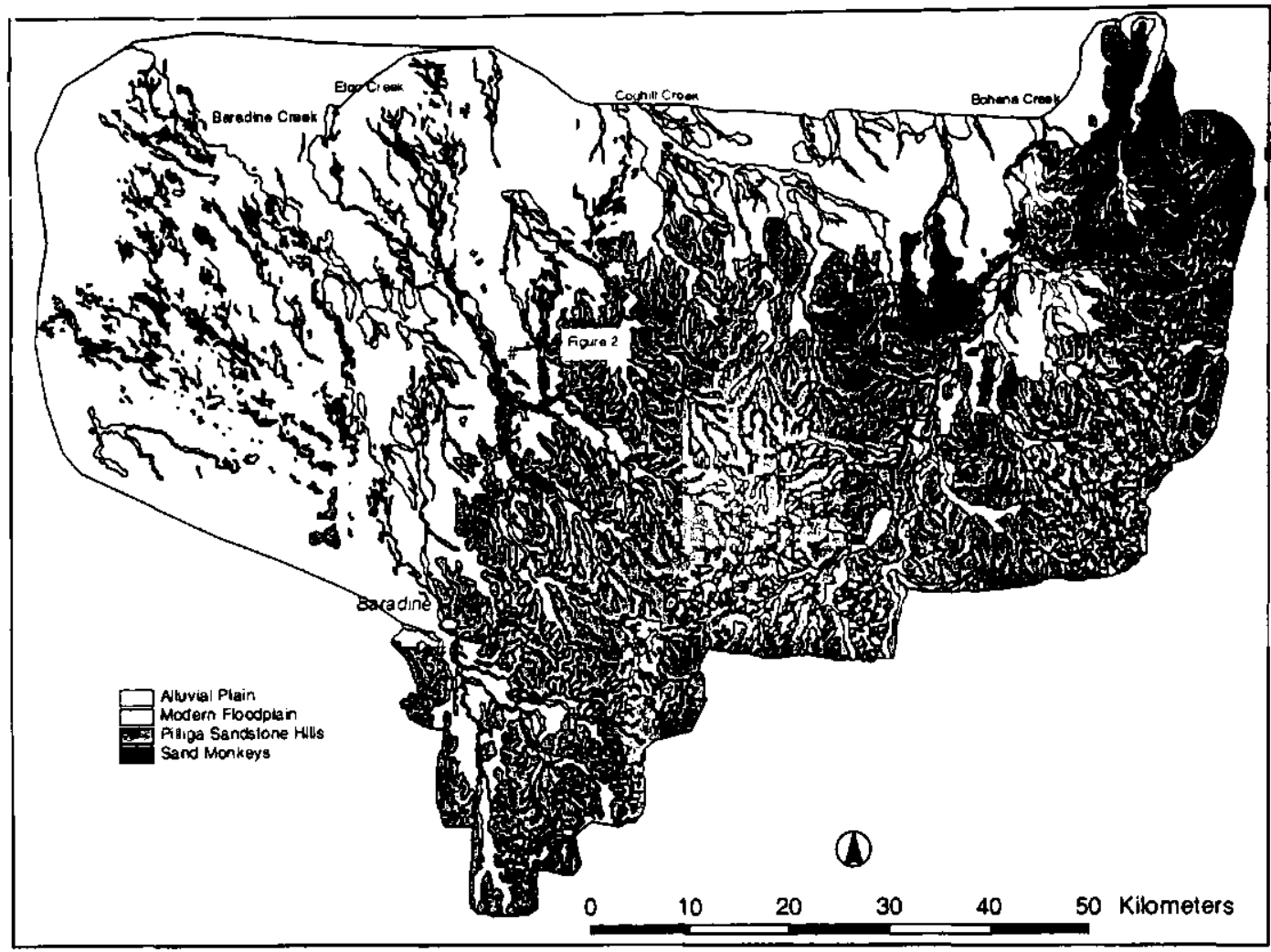

Figure 1. Geomorphic map of the Pilliga State Forests showing Pilliga Sandstone hills and Pilliga outwash plain. 'Sand monkey' palaeochannels are shown and their grouping into discrete fans can be seen (from Hesse, 2000).

In outcrop the Pilliga Sandstone has both massive and cross-bedded members, dominantly quartz sandstone with conglomerate beds throughout (Arditto 1982). Salt Caves represents one of the northernmost outcrops in the forest, again of iron-rich sandstone and conglomerate, in a gently northerly dipping very restricted outcrop. It is probably not part of the main cliffforming Pilliga sandstone, based on the geometry of the units. Toward the north, there is almost no natural outcrop and indications of the lithology come mostly from rock on or in the soil and the nature of the weathering profile. This pattern is repeated around Dunwerian Road, west of Ironbarks Crossing Road, where numerous soil pits have uncovered heavy clay subsoils developed on weathered lithic sandstone (Hart 1992; Norris 1996). 
Both the clay, with its strong subsoil cracking and doming, and the abundance of iron seem to be characteristic of the lithic sandstone (and also of the lower Purlawaugh Formation). Iron pisoliths are encountered on ridge tops over a wide area, but especially north of Burmah Road, and may indicate the extent of a lithic sandstone member which overlies the quartzsandstone cliff-forming unit thought of as typical of the Pilliga Sandstone Formation.

In general the effects of lithology on the landforms are strongest where there are two rock types in the same hillslope; usually a cliff-forming quartzsandstone at the crest and a more gentle slope formed on lithic sandstone toward the base. This pattern is seen in the southern part of the central forest, around Bugaldie, and on the eastern edge, overlooking the Namoi valley. Further north the relief is much more subdued and consequently the same quartz sandstone unit has a different expression. The different expression occurs because slope curvature (convexity/concavity) is inversely related to soil thickness and directly to bedrock exposure (Heimsath et al. 1997): on lower (less convex) slopes thicker soil mantles form and the same rock unit takes on a completely different appearance. Only very convex slopes (requiring deep valleys) can maintain cliffs and large areas of rock outcrop.

\section{Pilliga outwash plain}

The second landscape covers the north and west of the forest area and is an alluvial outwash plain formed by the sediment deposited by creeks draining the uplands over tens of thousands of years. The major creeks have contributed an enormous volume of sediment to the plain, which still records in its landforms the history of its construction. Abandoned channels of these creeks cross the plain, still tracing flow toward the Namoi River. Far from the modern channels, these ancient (palaeo-) channels are filled with sand to the extent that their surfaces are elevated above the surrounding clay plains. These are the well-known 'sand monkeys' (Hallsworth and Waring 1964), whose name is derived from an Aboriginal word.

The great bulk of the outwash plain sediments are those underlying the sand monkeys. These are very poorly exposed or understood. A deep gully beside the Baradine-Kenebri Road, adjacent to Baradine Creek exposes several metres of heavily weathered sediment, above Pilliga Sandstone, ranging from coarse sand and gravel to clay in a general fining-upward trend. The surface is capped with a texture contrast (duplex) soil, typical of 
large areas of the plain. Weathering features include apparent silica cementing at depth, columnar iron structures also at depth, and iron, manganese and carbonate nodules in the shallower sediments. The age of the sediments is unknown. Over large areas pedogenesis has lead to the formation of a very hard and impermeable pan (possibly silica cemented) in the shallow subsoil. This sometimes has a polygonal crack pattern developed in it and cemented faunal casts. This pan contributes to poor infiltration on the alluvial plain and enhances lateral runoff and the notorious boggy soils. In places, scalding has exposed the pan and formed claypans which retain water after rain storms. These are very evident in the Gilgai Flora Reserve and parts of the West Pilliga Forest. Other areas of the alluvial plain are notable for their heavy clay soils and gilgai. It is not clear what their relationship to the sandier sediments is, however their distribution shows them to be scattered over the alluvial plain. A single thermoluminescence date on these clays (on Pine Road, near an area of gilgai) returned a saturated age greater than 88600 years ago. It is reasonable to assume that the bulk of the alluvial plain sediments are as old or older and pre-date 80000 years ago, although it is not possible to say at this point whether they date to the late Quaternary (last 250000 years) or are much older. The amount of sediment, its position over bedrock and clay-rich texture point to an origin from widespread slope erosion and transport into the fluvial system.

Geomorphic mapping (Hesse, 2000) (Figure 1) shows that the sand monkeys form several distinct radiating fans related to Baradine, Etoo, Rocky and Talluba creeks. The size of the fans is roughly proportional to the catchment area of each of the creeks; the Baradine Creek fan of the West Pilliga forest being by far the largest. The sand monkeys in each creek system form two distinct zones; an upstream zone in the confined valley and some way out onto the alluvial plain where the sand monkeys lie in a confined belt, and a downstream zone where sand monkeys suddenly begin to diverge and radiate into a fan. In both zones there are segments of sand monkey which are continuous for hundreds of metres or even kilometres and preserve low sinuosity channel-like outlines. In places, continuous channels diverge from these and elsewhere crevasse-like sand splays are evident. Augering and excavation in the upper zones of the Etoo and Rocky Creek sand monkeys (Figure 2) show that the channels are broad and incised 2 to 6 metres into the clay-rich substrate sediments. In many cases the surfaces are raised above the surrounding plain leading to good surface drainage and distinctive vegetation communities. The sand monkeys appear to be complexes of sand-choked channels which have avulsed repeatedly to form the fan-like patterns in a form of channel breakdown, or floodout (Gore et al. 2000). This behaviour usually results from inefficient flows or 
excess sediment supply and in this case the most likely source of the massive quantities of sand is the erosion of upper valley sediment bodies. Bohena Creek, the largest creek in the forest, does not have a sand monkey fan. It has maintained a continuous channel all the way to the Namoi possibly because of its greater discharge or the shorter distance across the outwash plain to the Namoi River.

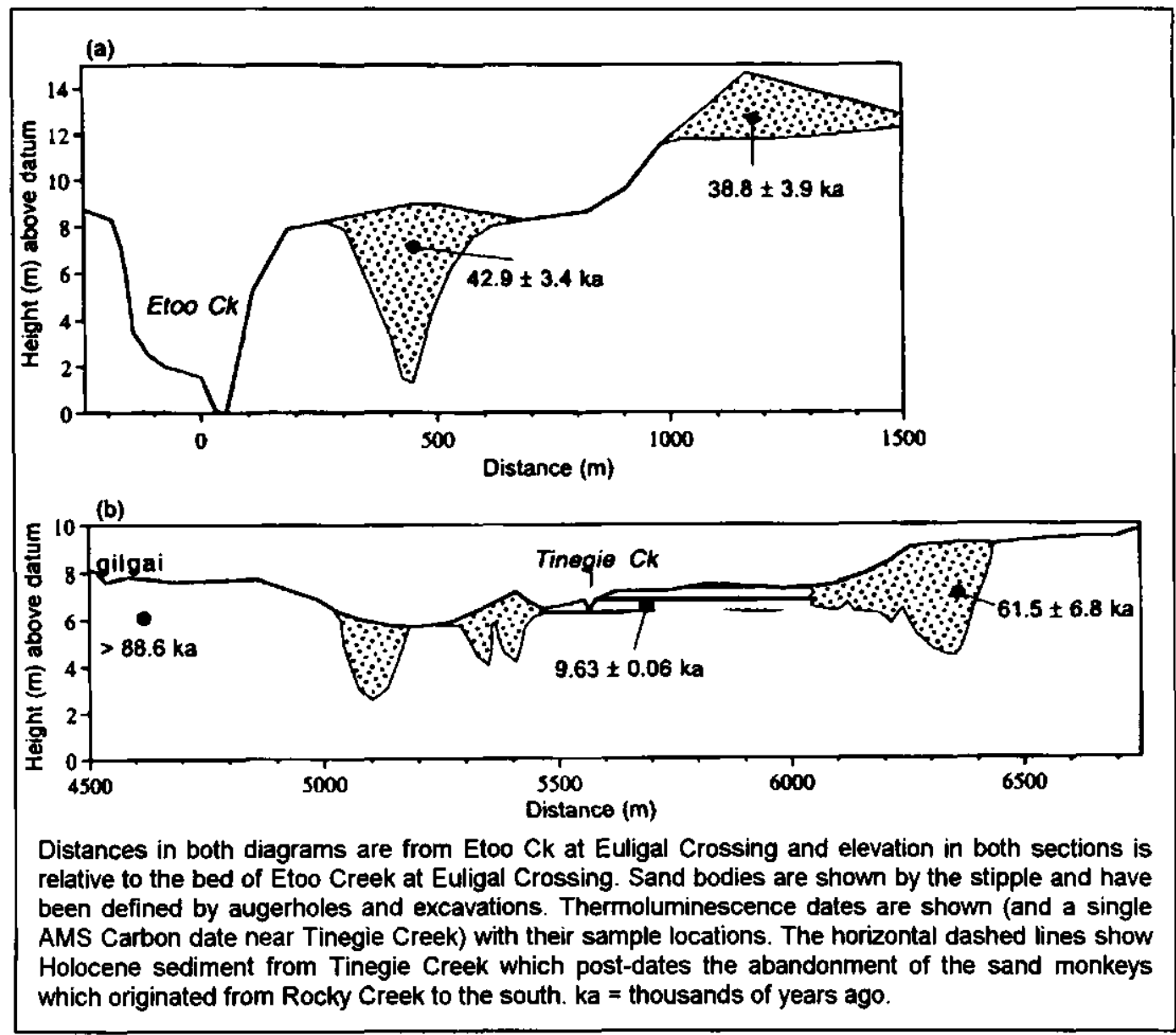

Figure 2. (a) Sand monkey and source bordering sand dune on a surveyed topographic transect along Pine Road from Euligal Crossing on Etoo Ck. (b) Sand monkeys, gilgai and Holocene sediment of Tinegie Creek on a surveyed topographic transect along Pine (left) and Dunwerian Roads, west of Ironbarks Crossing Road (see Figure 1).

Sand monkeys deriving from Rocky Creek and leading north toward Talluba Creek (Figure 2) have been dated by thermoluminescence and give ages of $45400 \pm 4100$ years ago and $61500 \pm 6800$ years ago. Adjacent to Etoo Creek, a channel-filling sand monkey was similarly dated to 42900 \pm 3400 years ago. This is essentially the same age as the younger of the dates 
on the Rocky Creek sand monkey. These dates represent the dying stages of these channels as they filled with sand and ceased to carry water. Surface sediments adjacent to the sand monkeys and the top $1 \mathrm{~m}$ of the sand monkeys give younger dates, the result of sediment turnover by bioturbation and partial bleaching of the sand grains. It is possible that the younger of the thermoluminescence samples from the Rocky Creek sand monkey has been affected by bioturbation because of its shallower burial. Sourcebordering sand dunes east of Etoo Creek near Euligal Crossing may have derived from the sand monkey channel while it was active or after it was abandoned (Kamper, 1997). The central age of the thermoluminescence date on the sand dune ( $38800 \pm 3900$ years ago) is statistically the same as for the sand monkey.

Ward (1992) has described an additional geomorphic/soil forming phenomenon in this area; the addition of wind-blown dust to the soil. $\mathrm{He}$ found that this dust could be identified in clay soils of the Pilliga outwash plain, just north of the Pilliga Forest, west of Bohena Creek. His data show that this aeolian component is usually a small part of the alluvium. The silt fraction can give heavy clay soils a more earthy, friable fabric. Hesse et al. (1998) found that the same wind-blown dust is present in the sand dune on Pine Road and forms about 20 percent by weight of the soil. The accumulation rate, assuming that the dust began to accumulate as soon as the dune formed 39000 years ago, is 2 grams per square centimetre of ground surface every thousand years, or a layer 1.5 centimetres thick every thousand years. It is likely, however, that most dust was deposited during the peak glacial interval (25000 to 15000 years ago) (Hesse 1994).

Unlike the confined creeks of today, the sand monkey streams crossed the surface of the plain in fairly shallow channels which were easily blocked by choking sand and could quickly jump (or avulse) to a new course. After about 40000 years ago, the main creeks eroded deeper tracts into the plain which they have occupied ever since. In the case of Etoo Creek the incised channel follows roughly the same course as the older channels, however in the other creek systems the new incised channels follow quite different courses. Within these tracts there is evidence of channel change, erosion and deposition, however they can now no longer avulse to follow new courses. The many smaller headwater creeks were passive and sediment starved, up to the time of European settlement. These valleys show shallow accumulation of alluvium or colluvium (slope-derived sediment) and thickly vegetated valley floors with very poorly developed channels. We postulate a Holocene age for these sediments and their characteristic hydrology. Many of these drainage lines are now heavily disturbed and show active gully and bank erosion. The erosion has released large volumes of sediment to be 
transported by the creeks. Nearly all this sediment comes from older valley sediments but is supplemented by erosion from roads. In all the creeks except Baradine Creek the impact of this erosion can be seen in the lower reaches as thick sand sheets covering the bed, filling waterholes and topping the narrow floodplains. Today, Baradine, Etoo and Talluba Creeks all break down and form floodouts before reaching the Namoi River.

\section{Late Quaternary climate change}

From these few results it is not possible to say that all sand monkeys on the alluvial plain date from the same period or that the period 40000 to 60000 years ago was particularly wet. Given the volume of sediment and range of textures it is likely that the sand monkeys formed during a period of only moderate, or waning, fluvial activity and that the major period of slope erosion and fluvial transport preceded the period of sand monkey formation. The sand monkeys therefore represent the 'last gasp' of the alluvial plain as upland sediment sources dried up and the creeks began to recycle their own sediments. The period following 80000 years ago was colder than before and possibly drier (Kershaw and Nanson 1993). Lower and possibly more 'flashy' discharge as well as less dense vegetation cover on the valley floors may have contributed to upper valley floor erosion and drainage breakdown on the alluvial plain.

The period after 40000 years ago was marked by much lower temperatures in inland southern Australia (Miller et al. 1997) and evidence of greater aridity. After about 40 ka the major creeks apparently incised over much of their length. This change indicates a susceptibility of the channels to erosion (ineffective plant cover) and an undersupply of sediment for transport.

The activity of the sand dunes around 40000 years ago is in broad agreement with the vegetation history as known. The dunes indicate much sparser vegetation in the area 40000 years ago, preceding the forest phase at around 30000 years ago seen at Ulungra Springs (Dodson and Wright 1989). At that time the world was in the early stages of the last ice age, with lower temperatures and periodically drier climates indicated by fluctuating lake levels (Bowler 1998).

The period following the last glacial saw significant climate warming and the return of forest vegetation to the region, leading to the conclusion that rainfall also increased after about 13000 years ago (Dodson and Wright 1989). Yet the fluvial landforms of the Pilliga, like those of other inland river systems (Page and Nanson 1996) do not show evidence of higher discharges but generally less fluvial activity. This anomaly is argued to be the result of 
greater transpiration loss from the enhanced biomass and less effective runoff. This is a feasible explanation for the landforms seen in the Pilliga, however it is also possible that low temperatures and low carbon dioxide levels suppressed the forests in the glacial period and that their rise in the deglacial period was, at least in part, responsible for the return of the forest. We simply do not have independent measures of precipitation which allow this question to be resolved.

\section{Contemporary geomorphic processes}

Most channels bear the marks of recent dramatic change. In higher areas there are spectacular gullies (new channels) formed by scouring of previously unchannelled drainage lines. The upper reaches of the major creeks show evidence of bank erosion in many places and all (except Baradine Creek) appear to be affected by sand accumulation in their lower reaches as a result. Very few waterholes remain and floodplains are being 'drowned' in sand from the widening channels. Rolls (1981) refers to the 'sanding-up' of the major creeks early in the 20th century. The lower reaches of the major creeks have become enormously wide sand streams which have no surface water between flood events.

Casual observation suggests that clearing and road building are both at least partly responsible for these changes in the creeks. The very widespread gullying is both recent and ongoing, and mostly relates to the period of forest management. There appears to be a strong association between road crossings and creek gullying, although sampling is biased toward these easily accessible points. The concentration of flows at culverts, disturbance of protective vegetation at crossings and addition of excess runoff from forest tracks may all play a role in encouraging erosion. Creeks draining cleared land often carry excess sand as the result of soil or bank erosion. Clearing on the forest margins may have triggered headward gully erosion into the forest in some areas. The scale of the disturbance in the Pilliga is such that disturbed channels appear to be 'normal'. Only close examination reveals the degree of change the creeks have suffered.

\section{References}

Arditto, P.A. 1982. Deposition and diagenesis of the Jurassic Pilliga Sandstone in the southeastem Surat Basin, New South Wales. Joumal of the Geological Society of Australia 29: 191-203. 
Bowler, J.M. 1998. Willandra Lakes revisited: environmental framework for human occupation. Archaeology in Oceania 33: 120-55.

Dodson, J.R. and Wright R.V.S. 1989. Humid to arid to subhumid vegetation shift on Pilliga Sandstone, Ulungra Springs, New South Wales. Quaternary Research 32: 182-92.

Gore, D., Brierley, G. Pickard J. and Jansen J. 2000. Anatomy of a floodout in semi-arid eastern Australia. Zeitschrift fur Geomorphologie, N.F. Suppl.-Bd. 122: 113-39.

Hallsworth, E.G. and Waring H.D. 1964. Studies in pedogenesis in New South Wales. VIII. An altemative hypotheses for the formation of the solodized-solonetz of the Pilliga district. Joumal of Soil Science 15: 158-77.

Hart, D.M. 1992. A field appraisal of the role of plant opal in the Australian environment. PhD Thesis (unpublished) School of Earth Sciences, Macquarie University, Sydney.

Heimsath, A.M., Dietrich, W.E. Nishiizumi K. and Finkel R.C. 1997. The soil production function and landscape equilibrium. Nature 388: 358-61.

Hesse, P. 1994. The record of continental dust from Australia in Tasman Sea sediments. Quatemary Science Reviews 13(3): 257-72.

Hesse, P. 2000. Geomorphology of the Goonoo and Pilliga forests, Brigalow Belt South Bioregion, in Report on indigenous cultural heritage assessment and community consultation of the Brigalow Belt South Bioregion, National Parks and Wildlife Service of NSW.

Hesse, P., Townsend F.N., Humphreys G. and Kamper S. 1998. Dust accession rates over the Late Pleistocene in Northern NSW; the potential for the formation of aeolian mantles and reworking within the landscape (abstract). Proceedings of a workshop on aeolian dust: implications for Australian mineral exploration and environmental management. Canberra, November 1998, CRC LEME Report 102.

Kamper, S. 1997. The origin and history of sand bodies in the Pilliga State Forest, NSW. Honours thesis (unpublished) School of Earth Sciences. Macquarie University, Sydney.

Kershaw, A.P. and Nanson G.C. 1993. The last full glacial cycle in the Australian region. Global and Planetary Change 7: 1-9.

Miller, G.H., Magee J.W. and Jull A.J.T. 1997. Low-latitude glacial cooling in the Southem Hemisphere from amino-acid racemization in emu eggshells. Nature 385: 241-4.

Norris, E. 1996. A study of the soil and vegetation pattems within part of the Pilliga forests, and an evaluation of the impact of European settlement on the vegetation. MSc Thesis (unpublished), School of Earth Sciences. Macquarie University, Sydney.

Page, KJ. and Nanson G.C. 1996. Stratigraphic architecture resulting from Late Quatemary evolution of the Riverine Plain, south-eastem Australia. Sedimentology 43, $927-45$.

Rolls, E. 1981. A million wild acres. Melbourne, Thomas Nelson.

Ward, W.T. 1992. Soils and landscapes near Narrabri and Edgeroi, NSW, with data analysis using fuzzy k-means. Soils and Land Use Series: 63. Division of Soils, CSIRO. 


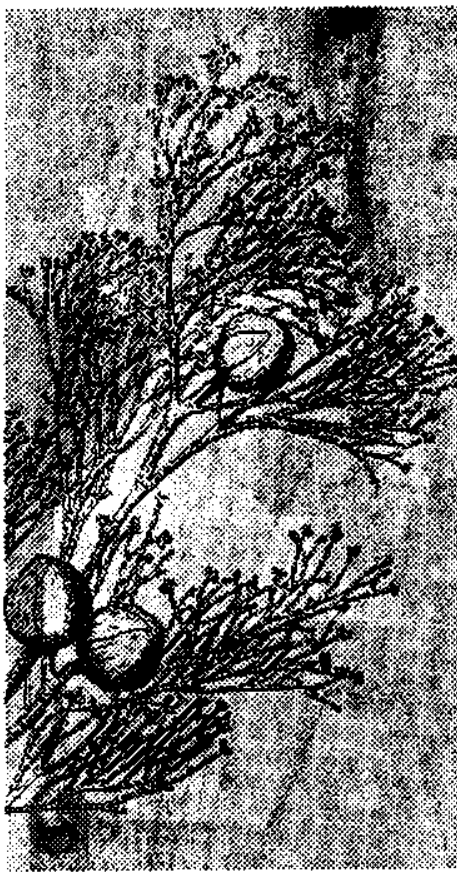

11

Litterfall and

decomposition in a white pine-ironbark community

Diane M. Hart

\section{Introduction}

Australian forests often occupy sites of low nutrient status, thus the rate of mineralisation of the litter affects the long term productivity of the forest. The rapid accumulation of combustible litter in these forests is an important consideration in forest management. Annual litterfall varies considerably between forest types. A survey of the literature since 1970 reports litterfalls of between 1670 and 7756 kilograms per hectare per year in Australian forests with few being from areas where Callitris glaucopbylla (white pine) is found (Hart 1992).

A litter study, conducted between 1987 and 1990 in the Pilliga East State Forest measured the amount of annual litter accumulation and decomposition rate of litter in a white pine-ironbark community (Forest) and compared it with adjacent Mallee and Broom communities. The study's primary objective was to obtain biomass data for a project investigating the cycling of biological silica (Hart 1992). It's secondary objective was to examine the degree of difference between the accumulation and decomposition of litter in several vegetation communities in one forest area. 


\section{Field sites}

The three field sites are located along Dunwerian Road in the Pilliga East State Forest in New South Wales, Australia (Figure 1). The Pilliga Sandstone, deposited some 160-136 million years ago and sediments derived from it form the surface geology of the Pilliga East State Forest. Annual rainfall is greatly variable, averaging 625 millimetres with a summer maximum. The vegetation is a sclerophyllous closed to open-forest with a heath understory and comprises a mosaic of vegetation communities.

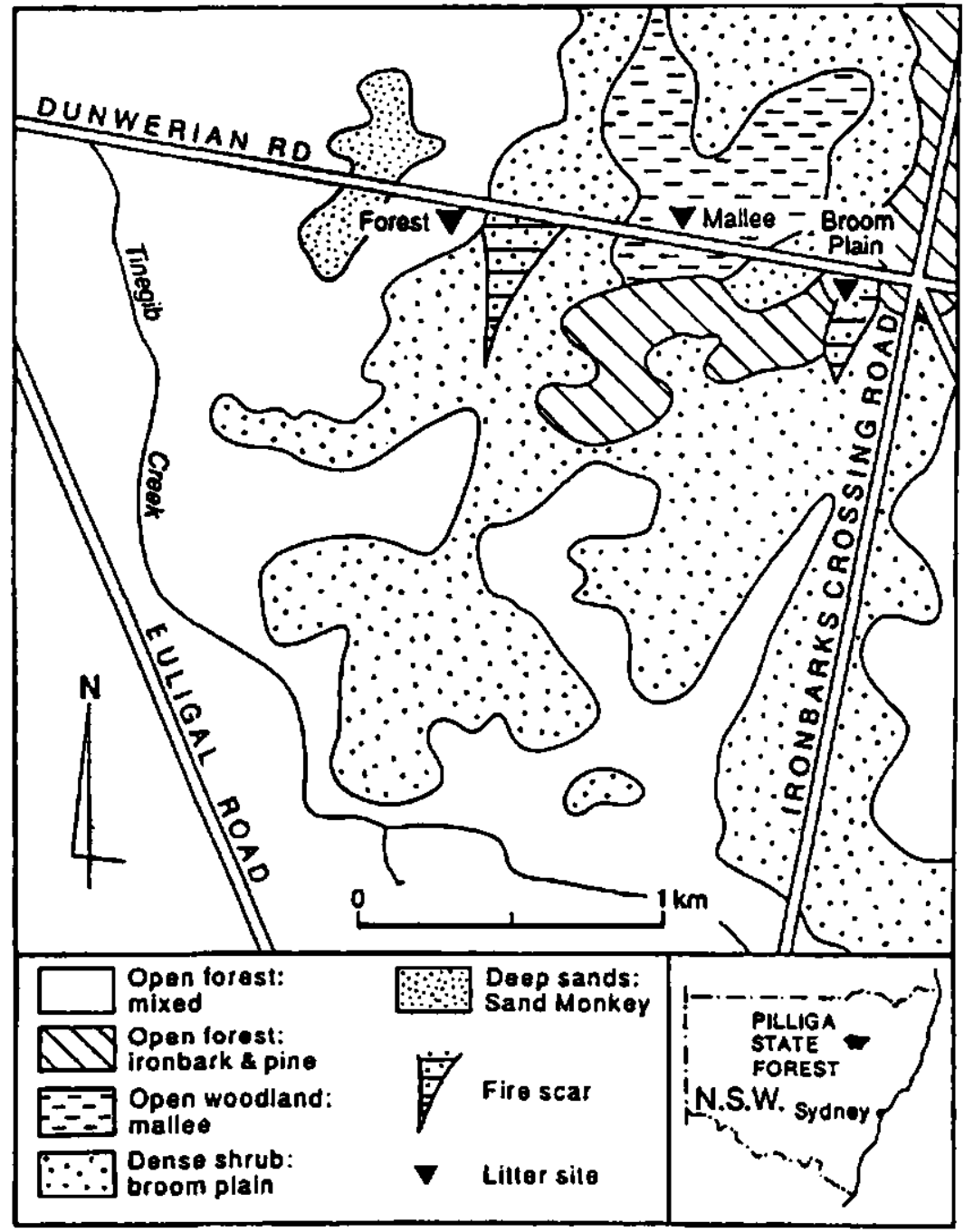

Figure 1. Location of the field sites within the Pilliga East State Forest.

The Forest is a mid-height closed to open woodland with crowns just touching (10-20 percent cover) and it has an abrupt boundary with the 
surrounding broom plain. It is a white pine-ironbark association comprising open woodland of Callitris glaucophylla (height to 15 metres) and Eucalyptus crebra (narrow-leafed ironbark) (height to 20 metres) with Acacia tindaleae (golden-top wattle) in the shrub layer and a mixed herb layer. It equates to the mixed forest community of Humphreys et al. (Chapter 10, this volume). The Mallee community comprises Eucalyptus viridis (green mallee) in the mallee (many stemmed) form (height to about 7 metres) and the shrub layer is dominated by Dodonaea viscosa ssp. cuneata (hop bush) with a herb layer containing various grasses. The Mallee and Forest sites last burned in 1951. The Broom plain, which last burned in 1966, comprises a very low heath of Melaleuca sp., Acacia sp. and Calytrix tetragona (common fringe-myrtle) 2 to 5 metres tall. The ground cover comprises lichen and moss mats between the shrubs.

\section{Methods and results}

At each site, ten mesh litter trays were located randomly within a $100 \times 100$ metre area. Collections were made regularly from each site over a period of 153 weeks (see Hart 1995 for details).

An initial and final litter collection was made within each site and, since the fire history of the sites was different, an additional litter collection was made in each community in sites last burned in 1951, to give comparable litter storage figures. Ten random collections were made within a $100 \times 100$ metre area at each site for each collection. Litter was sorted, dried at $110^{\circ}$ Centigrade and weighed (Table 1).

Thirty $200 \times 200$ millimetre mesh bags each filled with 20 grams of dried litter were tethered to the soil at each site to measure litter decomposition. Over 100 weeks, the bags were collected in groups of three from each site. The soil inside the mesh bags was separated from the litter by flotation and was then oven-dried and weighed. The decay constant and half-life of the litter was calculated using two methods (Table 2):

Method 1. X/ $\mathrm{X}_{0}=\mathrm{e}^{-\mathrm{kt}}$

where: $\quad \mathrm{X}=$ remaining litter mass after time $\mathrm{t}$,

$\mathrm{X}_{0}=$ initial litter mass,

$\mathrm{k}=$ decay constant, and

$0.693 / \mathrm{k}=\mathrm{t}_{0.5}$ (Olson 1963).

Method 2. $\mathrm{k}=\mathrm{L} / \mathrm{X}_{\mathrm{ss}}$

where: $\quad \mathrm{L}=$ rate of litterfall, and

$\mathrm{X}_{\mathrm{s}}=$ litter mass at steady state (Olson 1963). 


\begin{tabular}{lrrr}
\hline & \multicolumn{3}{c}{ Community } \\
\cline { 2 - 4 } & \multicolumn{1}{c}{ Forest } & Mallee & Broom \\
\hline Average annual fall $\left(\mathrm{kg} \mathrm{ha}^{-1}\right.$ year $\left.^{-1}\right)$ & 2286 & 3409 & 1005 \\
Initial collection $\left(\mathrm{kg} \mathrm{ha}^{-1}\right)$ & 11080 & 15860 & 2990 \\
Final collection $\left(\mathrm{kg} \mathrm{ha}^{-1}\right)$ & 12350 & 15960 & 7470 \\
Litter storage $\left(\mathrm{kg} \mathrm{ha}^{-1}\right)$ & 17311 & 12011 & 6293 \\
sites bumed in 1951 & & & \\
\hline
\end{tabular}

Table 2. Decay constant (k) and litter half-life and annual addition of sediment to soil

\begin{tabular}{lccc}
\hline & \multicolumn{3}{c}{ Community } \\
\cline { 2 - 4 } & Forest & Mallee & Broom \\
\hline Decay constant (k) mesh bag & 0.16 & 0.23 & 0.19 \\
Decay constant (k) litterfall & 0.13 & 0.28 & 0.16 \\
Half-life (years) mesh bag & 4.3 & 3.0 & 3.6 \\
Half-life (years) litterfall & 5.3 & 2.5 & 4.3 \\
Sediment addition $\left(\mathrm{kg} \mathrm{ha}^{-1}\right.$ year $\left.^{-1}\right)$ & 580 & 2250 & 1920 \\
\hline
\end{tabular}

\section{Discussion}

Both the Forest and Mallee appear to be in a steady state 36 years after fire, while the Broom, after 20 years, is not (Table 1). The Pilliga State Forests are protected from fire where possible, particularly in Callitris areas. Other litter studies reported from the Pilliga include Curtis (1975, cited in Bevege 1978) who found 7300 kilograms per hectare in storage in a mixed Callitris woodland, and a Forestry Commission fuel study 20 years after fire which found 6226 kilograms per hectare in storage (Van Loon and Love 1971).

The litter storage figures from areas last burned in 1951 and the mesh bag data were used to calculate $\mathrm{k}$ and the half-life (Table 2). Both methods give some comparative measure of the amount of litter removed annually, and both estimates agree that the Forest litter is the slowest to disappear.

Termites were largely responsible for the addition of soil material to the interior of the mesh bags (Hart 1995). The turnover rate for the surface 10 centimetres of the soil due to termites alone is calculated to be 306 years for the Broom, 261 years for the Mallee and 1014 years for the Forest. The Mallee and Broom communities' annual sediment far exceeded that of the 
Forest, and is a reflection of the annual litter production in each community. In the Mallee site, it was observed that a network of termite and ant channels existed under the surface and that termites were incorporating fresh litter into the soil before breaking it down. Thus the study examined disappearance rather than decomposition rates of litter.

\section{Conclusion}

The litter study demonstrated variation in annual litterfall and storage between vegetation communities in the Pilliga East State Forest. Callitris is mainly found in the forest community where the potential for litter to accumulate is high, leading to increased fire danger. In a Forest comprising a mosaic of vegetation communities, no one community's annual litterfall can be taken to be representative of the forest as a whole

\section{Acknowledgments}

The assistance of Macquarie University in supporting this research and the Forestry Commission of New South Wales for permission to conduct research in the Pilliga State Forests is gratefully acknowledged.

\section{References}

Bevege, D.I., 1978. Biomass and nutrient distribution in indigenous forest ecosystems. Queensland Forestry Department Tech. Paper No. 6.

Hart, D.M., 1992. A field appraisal of the role of plant opal in the Australian environment. $\mathrm{PhD}$ thesis, Macquarie University, NSW.

Hart, D.M., 1995. Litterfall and decomposition in the Pilliga State Forests, New South Wales, Australia. Australian Joumal of Ecology, 20, 266-72.

Olson, J.S., 1963. Energy storage and the balance of producers and decomposers in ecological systems. Ecology 44, 322-31.

Van Loon A.P. and Love, L.A., 1971. Fuel Equibibrium Studies in Dy Forest Types. Forestry Commission of NSW (Research Note F8/10, Taree Research Centre, Taree). 


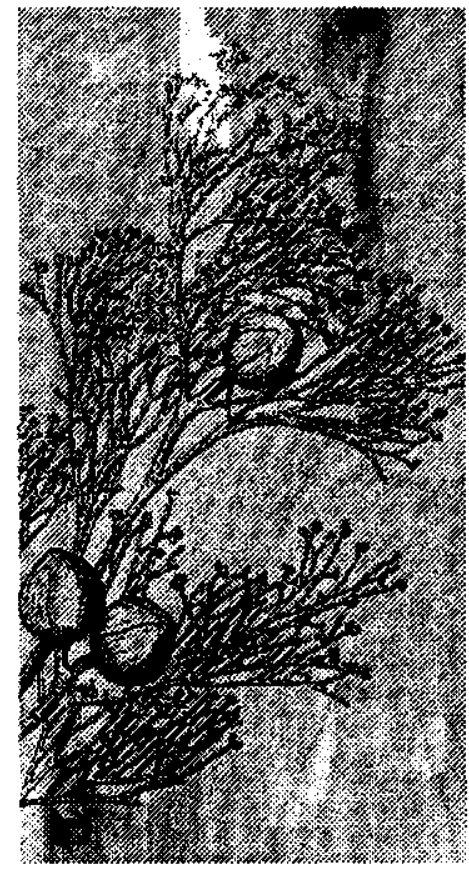

\title{
12
}

\section{Koala populations in the Pilliga forests}

\author{
Rod Kavanagh \\ and Elizabeth Barrott
}

\section{Introduction}

One of the more interesting findings to come out of the Pilliga in recent years has been the significance of this area for koala conservation in New South Wales (Barrott 1999, Date and Paull 2000). Mixed white cypress pine Callitris glaucophylla - Eucalyptus spp. forest is good habitat for koalas, with the animals commonly using white cypress pine for daytime shelter and feeding preferentially on the leaves of several species of eucalypts (Kavanagh et al. in press).

Historical accounts suggest that koala numbers in the Pilliga forests declined to very low levels during the early- to mid-twentieth century, but during the past 10-20 years they have been increasing dramatically. Koalas were common in the Pilliga forests during the mid- to late-1800s according to the limited historical accounts available (Rolls 1981, van Kempen 1997). However, a big decline in koala numbers apparently occurred during the period 1930-1980. These authors attributed the decline to widespread hunting of the koala by Europeans for their skins and for 'sport' (it has also been reported that the local Gamilaraay Aboriginal people hunted koalas for food and skins; van Kempen 1997), to predation by the European fox (which apparently arrived in the area during the period 1900-1910; Rolls 1981, van Kempen 1997), and to widespread ringbarking of eucalypts (which began in the 1930s; FCNSW 1986) to promote the growth and development of white 
cypress pine forests for timber harvesting. A reference is also made to the devastating effects of the 1951 wildfire which burnt out most of the central and eastern Pilliga forests (Rolls 1981).

Support for the notion that koalas were uncommon in the Pilliga during the period 1930-1980 is provided by interviews with long-term residents of the Pilliga region (reported by van Kempen 1997). For example, Mary Johnston of Baradine, who grew up at the Rocky Creek Mill near her family's property 'The Aloes' (in the central Pilliga) during the 1940s, saw only one koala when she was a child. It had been brought in by a timbergetter to show them as a curiosity. During eleven years stationed at Baradine, from 1946 to 1957, forester Bill Hindmarsh saw only two koalas. One longterm resident, Dan Casey, is reported to have said 'I drove this bush more than any other man in Australia and I never seen a koala until just lately'.

Since the early $1980 \mathrm{~s}$, koala numbers in the Pilliga appear to have increased. Another long-term resident, Mary Hitchen, is reported as saying:

No, never [did I see a koala when I was a kid], well there was the odd one around and if any sleeper cutter found it he'd bring it to town and show everyone, they were that rare. And now they're everywhere. There are so many of them around, right along the creek, just about every creek (van Kempen 1997).

Elaine van Kempen reports her own observations:

$\ldots$ in 1985, when I went to live at Baradine, I could always be sure of finding at least one [koala] to show visitors. By 1996, their numbers had increased dramatically.

Population increase by koalas in the Pilliga since the early 1980 s has been associated with the cessation of both hunting and broadscale ringbarking of eucalypts (van Kempen 1997). Ringbarking continued until the early 1980s (FCNSW 1986). Eric Rolls (1981) also associates time since wildfire with population recovery of the Koala: 'by the late 1970s, koalas had built up again in the forest after the 1951 fire and were seen where none had been seen for sixty years'. However, the role of the fox in regulating numbers of the koala remains unclear.

The status of the koala in New South Wales is currently regarded as 'vulnerable' (Threatened Species Conservation Act 1995), and the National Koala Conservation Strategy (ANZECC 1998) estimates the population of koalas in the State to be between 1000 and 10000 individuals. Two previous statewide (or national) surveys reported the koala to be widely distributed and locally abundant in many areas of Australia, with population concentrations occurring in several coastal locations of New South Wales (Gall and RohanJones 1978, Phillips 1990, Reed et al. 1990). However, these surveys may 
have underestimated the significance of the Pilliga forests for koala conservation.

In this review, we summarise data collected from two recent surveys of the koala within the Pilliga forests and conclude that the population may be much larger than previously thought. We also summarise results from recent research in the Pilliga to assess the role of several factors potentially threatening koala populations.

\section{Regional surveys}

Two regional surveys for the koala were conducted during the 1990s. Both surveys found koalas to be widely distributed throughout the Pilliga and more abundant than expected compared to other areas in New South Wales.

In 1993-1994, Date and Paull (2000) surveyed 90 transects, each 200 metres long, spread throughout the Pilliga. Sampling focussed mainly on the commercial forest types and was stratified by disturbance history and topographical position. Overall, evidence of koala presence (mainly by observations of koala faecal pellets) was recorded at 40 of these transects (44.4 percent). Koalas were recorded at 10 of 18 transects located in the Central Pilliga (56 percent); at 19 of 42 transects located in East Pilliga (45 percent); at 7 of 18 transects located in West Pilliga (39 percent); and at 4 of 12 transects in the Southern Pilliga forests (33 percent) (Date and Paull 2000).

In 1998-1999, Barrott (1999) surveyed 96 transects, each 400 metres long, spread throughout the Pilliga. Sampling was evenly balanced between forest types which were expected, on the basis of tree species composition, to provide good habitat or marginal habitat for koalas in the region. A wide range of disturbance history and topographical positions was sampled. Overall, evidence of koala presence (using a combination of five different survey methods) was recorded at 61 of 116 transect counts (52.6 percent). A small number of transects was surveyed on two or three occasions. During this study, a high proportion of records (77 percent) consisted of direct observations of the animals present at the time of the survey. The remaining records were indicated by the presence of koala faecal pellets. She recorded koalas at 33 of 46 transects located in the Central Pilliga (72 percent); at 27 of 40 transects located in West Pilliga (68 percent); and at one of 30 transects in East Pilliga ( 3 percent).

Thus, koalas were commonly found in the central and western parts of the Pilliga, but the two surveys reported different results for the eastern part. Barrott found koalas were uncommon in the East Pilliga forests. 
A preliminary estimate of population size for the koala in the Pilliga (based on Barrott's study) can be derived from the probability of detecting this species in each 'habitat quality class' in each zone. Assuming that only one animal was present at each site (usually more were recorded; Barrott 1999), that animals did not have overlapping home-ranges (radio-tracking studies showed that home-range overlap was common), and that average home-range size was 15 hectares (median annual home-range size for 30 animals radio-tracked in the Pilliga was 16.6 hectares; Kavanagh et al. in press), then at least 9984 koalas were estimated to inhabit the 322387 hectares of State Forest that was not burnt during the 1997 wildfire. Areas not sampled or involved in these calculations include the area burnt in the 1997 wildfire (143000 hectares) and the Pilliga Nature Reserve (approx. 85000 hectares, about half of which was not burnt in 1997). This additional area of approximately 185000 hectares could also be expected to provide habitat for koalas. Thus, the number of koalas living in the Pilliga forests during the late $1990 \mathrm{~s}$ is estimated conservatively to be at least 15000 animals.

\section{Threatening factors}

Logging and wildfire are two factors that may possibly threaten koalas. Logging effects were assessed in two ways: firstly, by correlating koala presence on regional survey plots with assessments of the degree of previous logging disturbance; and, secondly, by observations of radio-tagged animals before and after logging on controlled harvesting blocks. Fire effects were assessed by correlating koala presence with evidence of recent wildfire on regional survey plots.

In Barrott's (1999) study, 70 percent of all transects sampled in west Pilliga displayed evidence of logging (based on observations of cut stumps), but none showed any signs of previous wildfire (based on observations of charcoal on tree trunks). In the Central Pilliga, 50 percent of these transects had been logged, but only 2 percent had been burnt. In contrast, while 33 percent of transects in East Pilliga displayed evidence of previous logging, 57 percent of these transects had also been burnt by wildfire. Thus, on average, about half of the transects sampled throughout the Pilliga had been logged at least once previously, but nearly all those burnt by wildfire occurred in the East Pilliga zone. The highest frequency of detection of the koala occurred in western and central Pilliga, the zones where logging was most widespread but which were least affected by wildfire. In contrast, the lowest frequency 
of detection of the koala occurred in East Pilliga, the zone most affected by wildfire.

Across all transects in the Pilliga, the probability of detecting a koala was independent of logging intensity, except at the most extreme levels of logging intensity when detectability declined to zero (Figure 1).

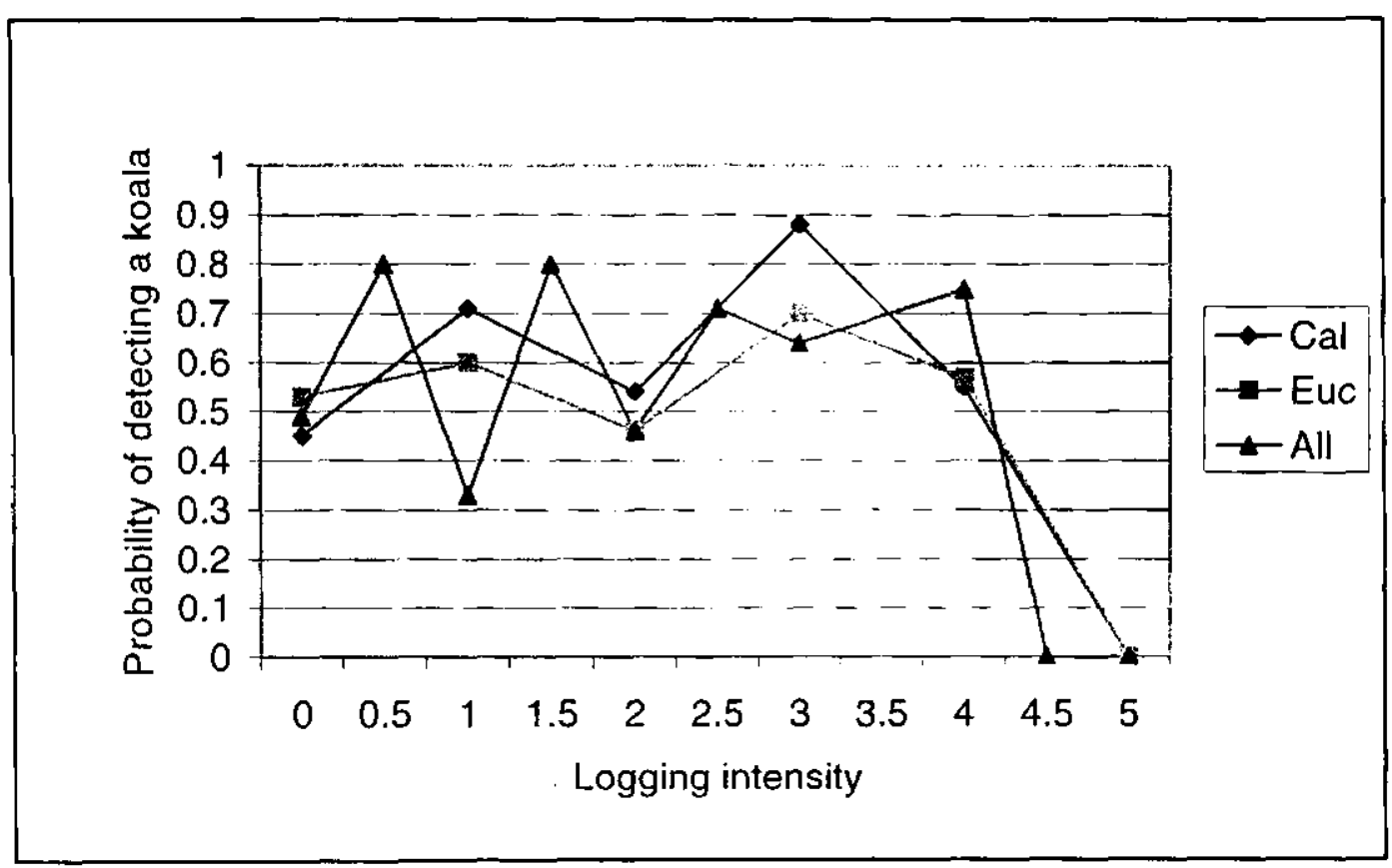

Figure 1. Detectability of the koala in relation to logging intensity in the Pilliga forests. Legend: $\mathrm{Cal}=\mathrm{Ca}$ llitris spp.; Euc $=$ Eucalyptus spp.; $\mathrm{All}=$ all tree species combined. Logging intensity assessed on a subjective scale of $0-5$, based on the number of cut stumps and the number of trees remaining on the site.

The history of major wildfires in the Pilliga since 1950 is shown cumulatively in Figure 2. The largest single wildfire occurred in 1951 and this fire burnt out nearly all of East Pilliga and the eastern half of the Central Pilliga. Other significant wildfires occurred during 1957, 1958, 1966, 1974, 1982 and 1997. Smaller wildfires occurred in 1970, 1977, 1978 and 1979. The most recent wildfire (1997) burnt a total of 143000 hectares. Thus, the greatest effects of fire have fallen upon the forests of East Pilliga and the eastern half of the Central Pilliga, including the Pilliga Nature Reserve, while most of West Pilliga and the western half of the Central Pilliga have not been burnt for more than 50 years. 


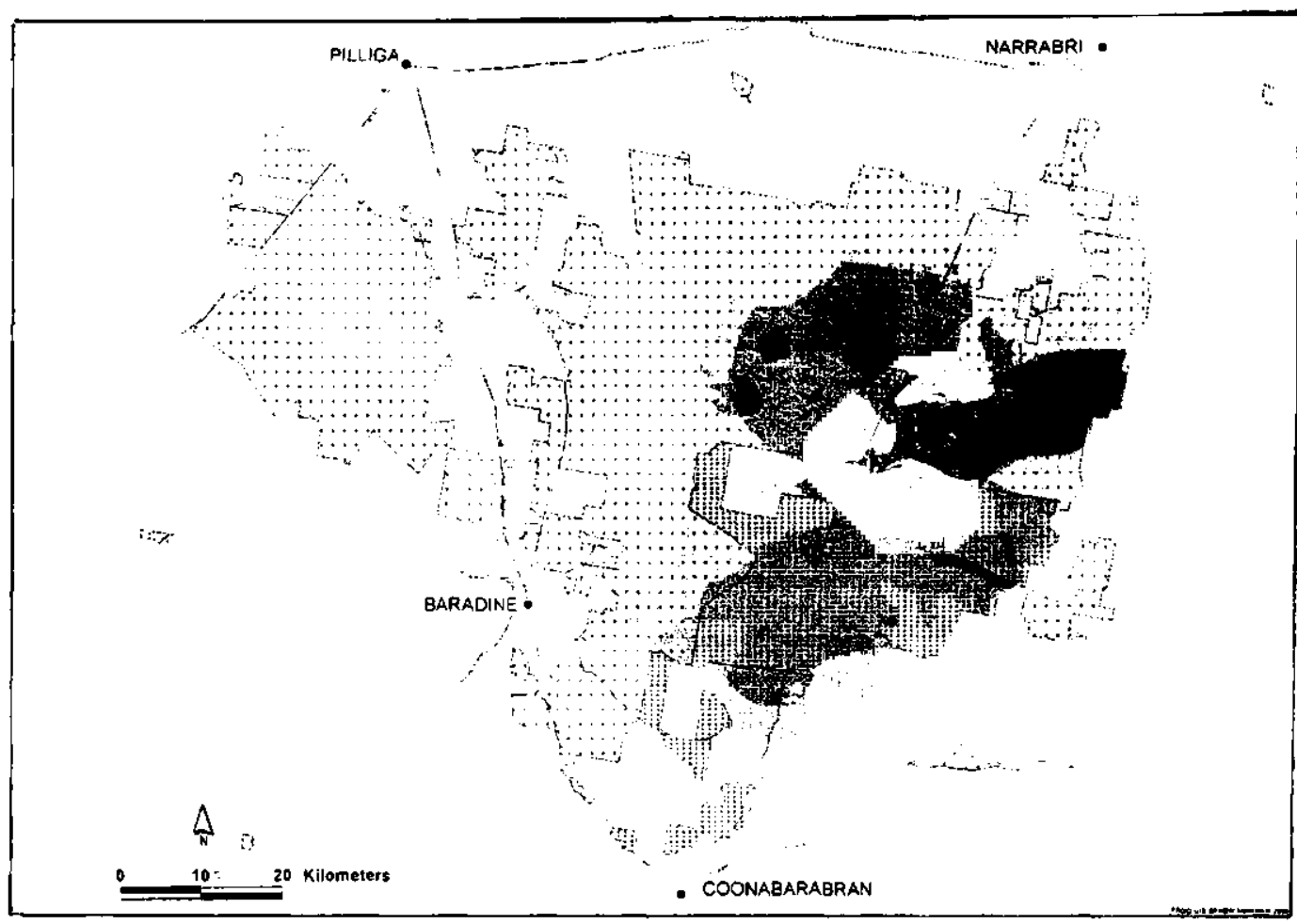

Figure 2. Cumulative history of wildfires occurring throughout the Pilliga forests since 1950 . Increasing intensity of shading corresponds to the greater frequency of wildfires, up to five events, experienced at some locations.

These data suggest that there may be a negative association between koala occurrence and areas that have been burnt by wildfire, but that any association between koala occurrence and logging is much less apparent. Of course, there are likely to be other factors which are important in explaining the distribution and abundance of koalas in the Pilliga. A controlled experimental approach is needed to unravel confounding influences and thus illuminate the effects of logging on koalas, and this is what was done.

An experimental logging study during 1997-98, in which radio-collared animals were monitored before, during and after selective logging of white cypress pine, showed that koalas continued to use their previous homeranges after logging (Kavanagh et al. in press). In this study, 30 koalas were radio-tracked in six study areas for one year. Several months after the study began, three of these study areas were logged for sawlogs and thinnings of the white cypress pine, removing approximately 25 percent of the total basal area on the sites but leaving the eucalypt component (approximately 50 percent) of these mixed forests unlogged.

One measure of the effect of logging is whether the animals continued to use their existing home-ranges after logging. This is indeed what happened. 
For example, inspection of koala home-ranges before and after logging in one study area (Compartment 196 in the Pilliga) shows that the animals continued to occupy their previous home-ranges after logging (Figure 3).

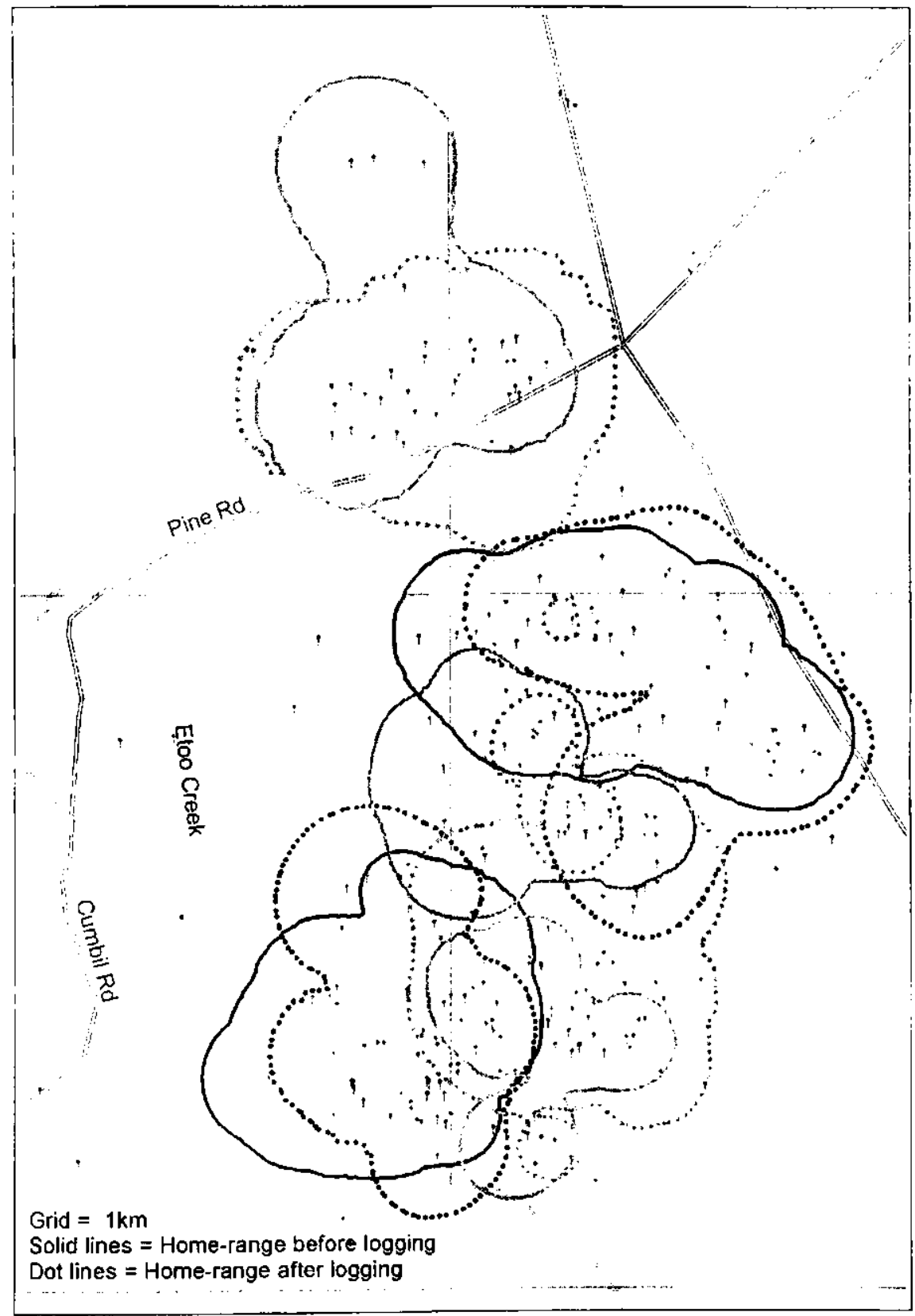

Figure 3. Distribution of home-ranges (calculated using the Adaptive Kernel method with 95 percent contours; Kie et al. 1994) for five radiotagged koalas before and after selective logging in Compartment 196, Pilliga forests. Solid lines indicate home-ranges for each animal before logging; dotted lines indicate home-ranges after logging. 
Another measure of the effect of logging is the subsequent breeding success of the animals. In Kavanagh's study, four of six adult females on the unlogged study areas produced one young each (67 percent) and three of four adult females produced one young each on the logged study areas (75 percent). These limited data suggest that koala breeding success was also not affected adversely by selective logging for white cypress pine.

While the eucalypts in this study were not logged, they clearly are important to koalas as they represent the primary food source for these animals. An indication of the minimum number of eucalypt trees per hectare required by koalas within their home-ranges is given in Figure 4. These data suggest that a threshold in habitat quality for the koala may exist corresponding to the presence of at least 20 eucalypt trees per hectare that are each larger than 20 centimetres in diameter (at breast height).

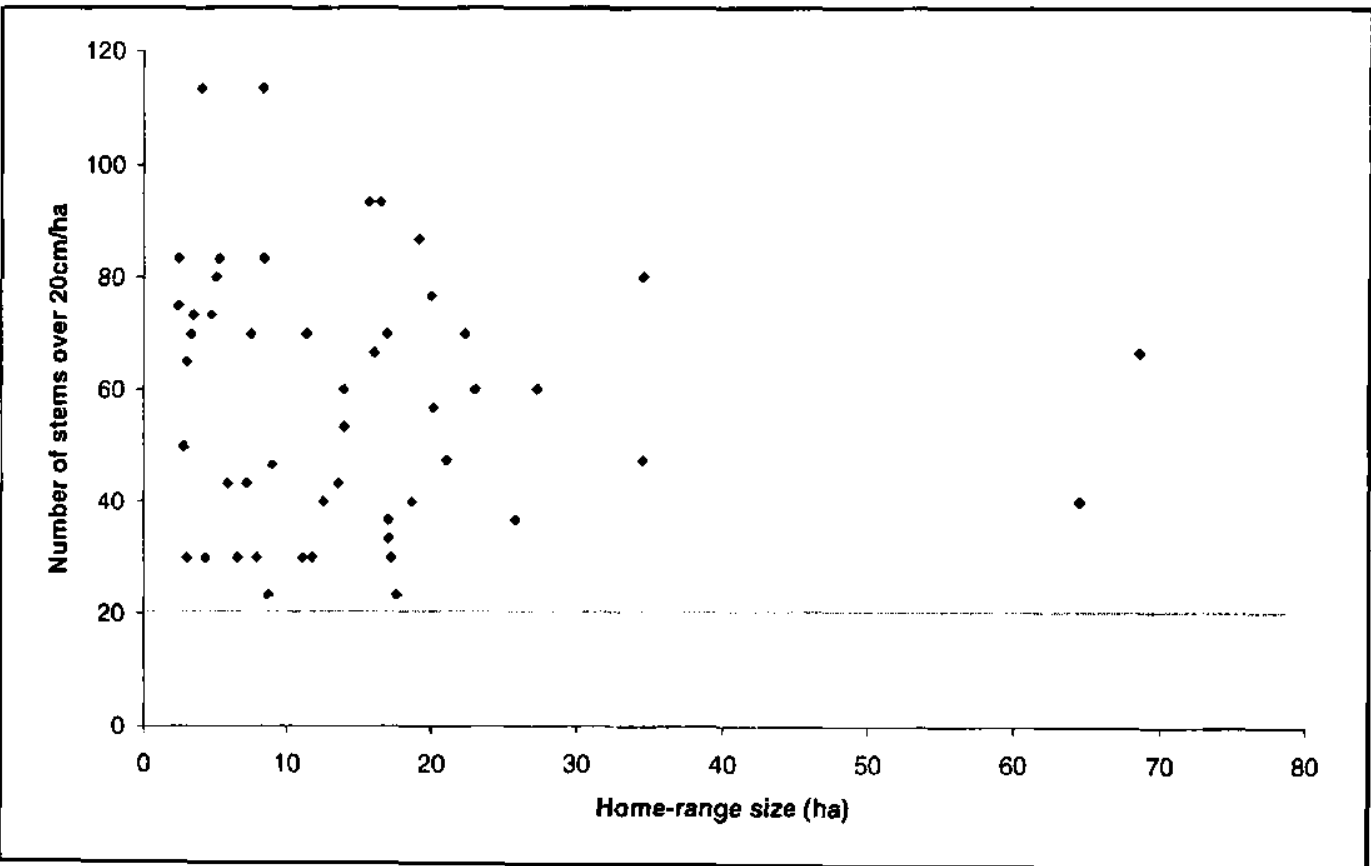

Figure 4. Number of eucalypt stems (larger than $20 \mathrm{~cm}$ diameter at breast height) per hectare occurring within the home-ranges of 32 radiotagged koalas in the Pilliga. Data include counts before and after logging for animals whose home-ranges were logged during the study.

Other factors potentially threatening the koala in the Pilliga include thorn-stick injury by the introduced cactus tiger pear Opuntia aurantiaca, predation by introduced animals (pigs, dogs, cats, foxes), and heat stress. Septicaemia resulting from thom-stick injuries by the tiger pear plant was diagnosed as the cause of death for two radio-tagged koalas during this 
study. When captured, most animals were found to have nasty scarring and infections on their feet. Tiger pear appears to have a localised distribution in the Pilliga (Doug Binns, personal communication) but it is common within a 10 kilometre radius of 'The Aloes' in the western portion of Central Pilliga.

Two radio-tagged animals in this study were eaten by predators, although it is not clear if predation was the primary cause of death. Opinions of longterm residents within the Pilliga suggest that the fox has been a significant factor reducing populations of the koala (Rolls 1981, van Kempen 1997). However, among the $125 \mathrm{dog}$ and fox scats collected by Date and Paull (2000), only one scat (a dog scat) contained any koala remains.

Drought and associated heat stress is also a cause of koala mortality. During the study by Kavanagh et al. (in press), two periods of up to 12 consecutive days were recorded when daily maximum temperatures exceeded $40^{\circ} \mathrm{C}$. Despite the study being conducted in a 'wet' year, under these conditions of extremely high temperatures nearly all 30 radio-tagged animals were found sheltering on the ground by day under any sort of cover they could find. This included inside old hollow logs and down rabbit burrows. Two animals died during the study from dehydration and burrow entrapment. Lung congestion, due to an unknown cause, was responsible for the death of two further animals during the study. However, it is worth noting that the Pilliga koalas are generally very healthy and have a very low incidence of Chlamydia related diseases compared to koala populations elsewhere (Jeff McKee, personal communication).

\section{Discussion}

The results of the two regional surveys conducted during the 1990 s indicate that koalas are indeed more widespread and abundant in the Pilliga than previously thought. In an historical context, koalas now appear to be more common in the Pilliga than at any time during the past 70 years. The apparent abundance of the koala in the Pilliga suggests that state-wide population estimates for this species (ANZECC 1998) need to be revised upwards.

Koalas are most common in the western half of the Central Pilliga, fairly common in West Pilliga, and apparently least common in the eastern and southern Pilliga. Results for East Pilliga differed between the two regional surveys conducted during the 1990s (Barrott 1999, Date and Paull 2000). Good habitat for the koala apparently exists in East Pilliga but it seems to be more patchy than elsewhere. The pattern of wildfire history might provide an explanation for the absence of the koala in many areas of apparently suitable habitat. 
The most important factor potentially threatening koala populations in the Pilliga is wildfire. Historically, hunting and excessive timber cutting or culling of eucalypts appear to have been very significant threats. It is assumed that hunting is no longer an issue. Ringbarking of eucalypts is also no longer a significant issue (FCNSW 1986), and eucalypt saplings are now found commonly among the cypress forests. Logging for sawlogs and commercial thinning of the white cypress pine within mixed white cypress pine-eucalypt forests was shown by Kavanagh et al. (in press) to have minimal adverse effects on the koala. This result might be expected given that the food trees of the koalas (the eucalypts) were not logged. The effects of harvesting eucalypts for sleepers or other wood products remains unknown. However, the existence of a threshold in habitat quality for koalas that was related to the abundance of eucalypts within the stand was inferred.

Locally, there are significant threats to koala populations due to tiger pear, and possibly also to the presence of introduced predators. More work needs to be done to control tiger pear and to assess the significance of feral predators in limiting koala survivorship in the Pilliga. Similarly, the role played by disease needs further assessment.

Heat stress may be controlled by ensuring that some large, healthy white cypress pines are retained per hectare after logging operations. Koalas displayed a strong preference in summer for daytime shelter in white cypress pines (Kavanagh et al. in press). Minimising disturbance to forests along creeks and other drainage lines might also be helpful because these areas are likely to provide more vigorously growing leaf tips and a higher moisture content in the foliage.

White cypress pine has increased dramatically in abundance within the past 50 years in the Pilliga as a result of many factors, including deliberate management. It is tempting to speculate that this change in forest structure may have benefited the koala. Given the long history of disturbance in these forests, it is apparent that koala populations can survive and prosper in forests used for wood production but vigilance is required to maintain a certain minimum number of eucalypt trees within forest stands.

Finally, there is a great need for koala surveys to be undertaken in surrounding national parks, nature reserves, and in apparently suitable forests to the north-west near Walgett. Unfortunately, good vegetation maps are currently lacking for these areas, and those for the Pilliga state forests need to be revised because they were prepared nearly 50 years ago. The Pilliga forests clearly represent an important source population of koalas and, in conjunction with strategic habitat restoration connecting surrounding 
areas and reserves, these forests are likely to provide a significant conservation area for koalas in New South Wales.

\section{Acknowledgments}

Thanks are due and warmly given to the many people who assisted with Koala research in the Pilliga during 1997-1998. In particular, RPK would like to thank Matthew Stanton and Traecey Brassil (Research Division, State Forests of NSW) for their tremendous assistance with fieldwork and data analysis. Also, special thanks to the primary research collaborators involved in this and related aspects of the 'Pilliga Koala Research Project', in particular John Callaghan (Australian Koala Foundation) and Jeff McKee (University of Queensland). Many other people assisted with fieldwork and otherwise gave great support for the project. The continuing interest and support by local staff of State Forests of NSW and the National Parks and Wildlife Service was vital for the success of this project.

\section{References}

ANZECC-Australia and New Zealand Environment and Conservation Council 1998. National koala conservation strategy. Canberra: Environment and Conservation Council Environment Australia.

Barrott, E. 1999. Census techniques, habitat use and distribution of Koalas in the Pilliga State Forests. B.Sc. (Hons.) thesis, School of Biological Sciences, University of Sydney.

Date, E.M. and Paull, D.C. 2000. Fauna survey of the Cypress/Ironbark forests of north-west New South Wales. Dubbo: State Forests of New South Wales.

FCNSW-Forestry Commission of NSW 1986. Management plan for the Pilliga Management Area. Sydney: The Commission.

Gall, B. and Rohan-Jones, W. 1978. Koala survey. Parks and Wildlife 2(2), 64-67.

Kavanagh, R.P., Stanton, M.A. and Brassil, T.E. (in press). Koalas continue to occupy their previous home-ranges after selective logging in the Pilliga forests of north-western New South Wales. Pacific Conservation Biology.

Kie, J.G., Baldwin, J.A. and Evans, C.J. 1994. CALHOME: Home range analysis program. PSW Research Station, Fresno, Califomia: USDA Forest Service.

Phillips, W. 1990. Koalas. The little Australions we'd all bate to lose. Canberra: Australian National Parks and Wildife Service.

Reed, P.C., Lunney, D. and Walker, P. 1990. A 1986-1987 survey of the koala Phascolartos cinereus (Goldfuss) in New South Wales and an ecological interpretation of its distribution. pp. 55-74 in Biology of the koala. A.K. Lee, K.A. Handasyde and G.D. Sanson (eds). Sydney: Surrey Beatty and Sons.

Rolls, E. 1981. A million wild acres: 200 years of man and an Australian forest. Melbourne: Nelson. van Kempen, E. 1997. A history of the Pilliga gppress pine forests. Sydney: State Forests of New South Wales. 


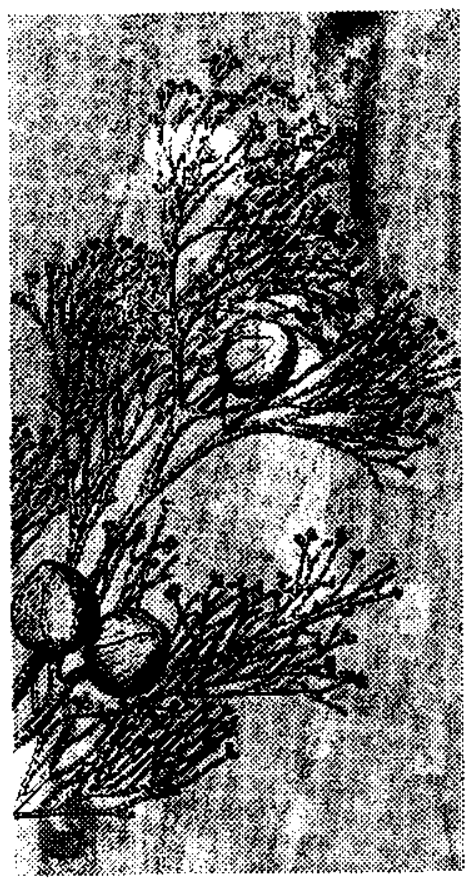

\section{3}

\section{Floristic patterns in the Pilliga}

\section{Doug Binns and Doug Beckers}

\section{Introduction}

The forests and woodlands of the Pilliga area, between Narrabri and Coonabarabran in north-western New South Wales, form the largest consolidated block of woody vegetation in an extensively-cleared region. The Pilliga State forests and Pilliga Nature Reserve occupy approximately 470000 hectares of this area. The area is bounded by latitudes $30^{\circ} 20^{\prime} \mathrm{S}$ to $31^{\circ} 15^{\prime} \mathrm{S}$ and longitudes $148^{\circ} 35^{\prime} \mathrm{E}$ to $149^{\circ} 55^{\prime} \mathrm{E}$. The geology is predominantly Jurassic sediment, mostly sandstone or conglomerate, although there are small patches of basalt. Elevation varies from about 460 metres in the south-east to 180 metres in the north-west. There is a gradual fall from the more dissected south-eastern areas with frequent sandstone outcrops and typically shallow sandy soils through the very gently undulating central section to the flat north-west where soils are deeper and often heaviertextured. Watercourses are broad, sandy channels in the east and centre, but hardly defined in the west. Rainfall varies from an average of about $700 \mathrm{~mm}$ per year in the east to $450 \mathrm{~mm}$ in the west. There is a long-term average peak in early to mid-summer and a smaller peak in mid-winter, but variability within and between years is great.

The value of this area for biological conservation has long been recognised. It has attracted a great deal of botanical activity by both professional and amateur botanists, but there has been no systematic botanical survey 
reported. This paper describes broad patterns of the terrestrial vascular flora of the area.

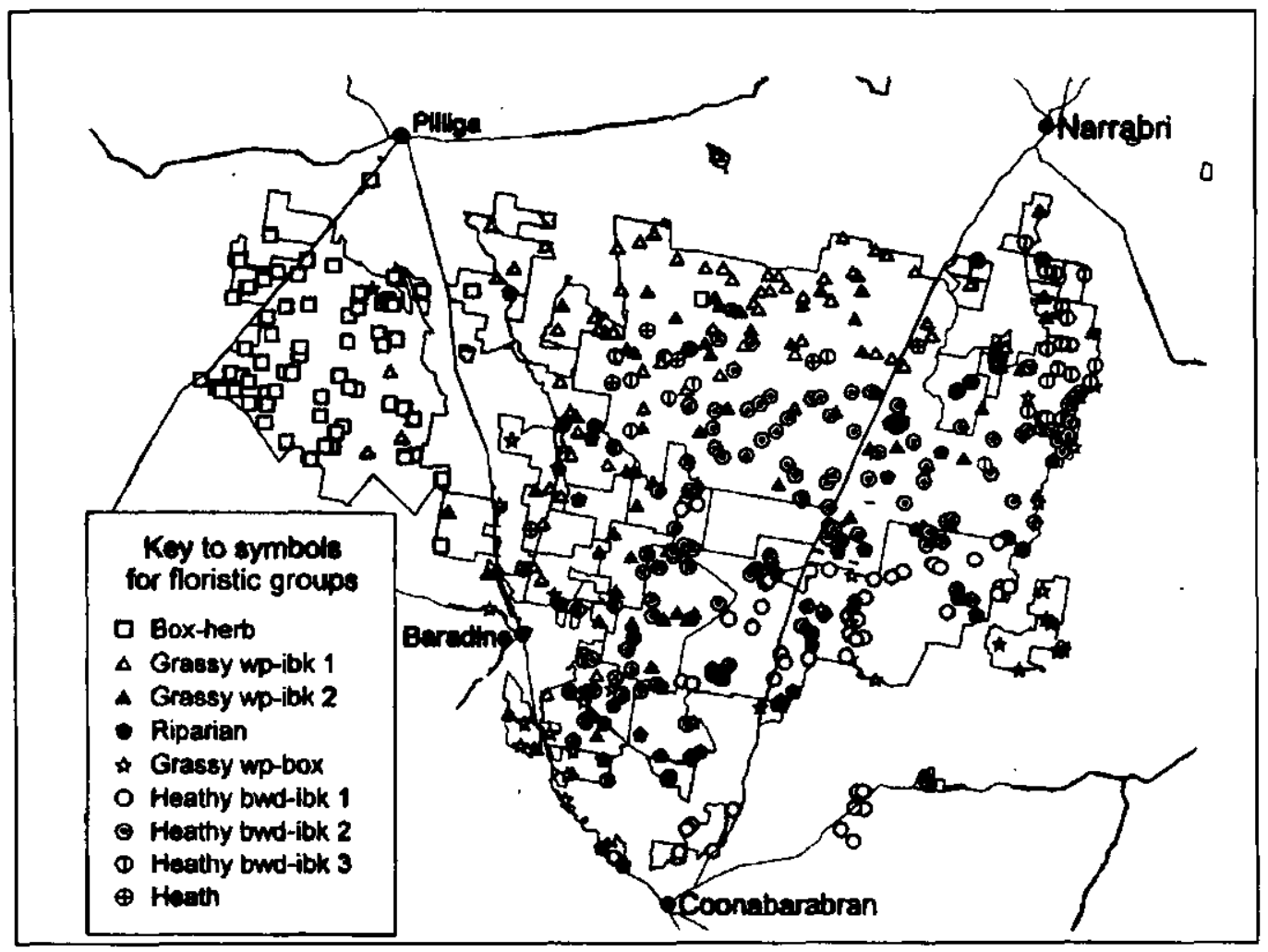

Figure 1. Distribution of sample plots and floriatic groups.

\section{Methods}

Data were derived from a total of 482 non-permanent plots, each 0.1 ha, established within the study area. Plots were located randomly, stratified by mapped forest type where available and otherwise (mainly in the Pilliga Nature Reserve) by broad topographic classes. Plots were rectangular, mostly $50 \times 20$ metres but up to $100 \times 10$ metres for riparian vegetation. All vascular plant species which could be distinguished within a plot were recorded and a cover-abundance code estimated for each species (codes based on projected canopy cover are: (1) $=<5 \%$, few individuals; $(2)=<$ $5 \%$, any number of individuals; $(3)=5-25 \% ;(4)=26-50 \% ;(5)=51-75 \%$; $(6)=>75 \%$ ). Field work was carried out over several seasons. On some occasions seasonal species (including many Orchidaceae) and ephemeral species may have been overlooked. Floristic data were classified into broad vegetation communities by grouping floristically similar plots using a 
numerical hierarchical agglomerative classification process, using the BrayCurtis association measure and a flexible UPGMA sorting strategy with beta $=-0.1$ (FUSE module of the PATN package, Belbin 1995). Groups were defined at the major point of inflection in a plot of the homogeneity (Bedward, Keith and Pressey 1992).

Due to the different numbers of plots in each group, total floristic richness was compared among groups by constructing species accumulation curves by repeatedly randomly selecting subgroups of plots and calculating the mean number of species for each size of subgroup. In each case, the mean was calculated from 100 random sub-samples.

\section{Results}

Totals of 753 native species (some with several subspecies) and 100 exotic species were recorded in the sample plots. The number of native species per plot ranged from 11 to 75 , with an average of 43.1 . The number of exotic species per plot ranged from zero to 29, with an average of 2. Most plots had less than 5 exotic species and 164 plots (34 per cent) contained no exotic species. The most frequent exotic species were Hypochoeris glabra (cat's ear) in 180 plots and Opuntia stricta (prickly pear) in 102 plots. The exotic flora comprises just under 12 per cent of the total flora. This is a relatively low percentage compared to smaller remnants of natural vegetation elsewhere in the Brigalow Belt South bioregion.

Callitris glaucophylla (white cypress pine) was the most frequently recorded tree species and the fourth most frequently recorded species overall, occurring in 288 plots (60 per cent of the total). Callitris endlicheri (black cypress pine) was less frequently recorded, occurring in 158 plots. The two species co-occurred in only 59 plots. This represents a very highly significant negative association. Eucalypts (in the broad sense, including Corymbia spp. and Angophora spp.) were present in every plot in which one of the two Callitris species occurred, but 85 plots contained eucalypts but neither of the two Callitris spp.

Based on the classification, broad floristic patterns in the area may be summarised in nine groups (excluding two plots in low woodland dominated by Acacia barpopbylla, occurring in separate remnants just north of the main block). These groups represent six major floristic elements and may be thought of as plant community types or associations. They are analogous to broad forest types, but include all vascular plant species rather than just trees. The groups are defined on a range of overstorey and understorey species. They overlap substantially in floristic composition and are not 
clearly-defined discrete entities, but they provide a convenient means of summarising floristic information for the area. The main diagnostic and characteristic species for each group are indicated in Table 1.

Table 1. Main overstorey and characteristic understorey species for each floristic group. Frequency (percentage of plots in the group) in which the species was recorded is shown in parentheses.

Floristic group No. of Main overstorey species $(E .=$ Eucalyptus, $C .=$ Callitris $)$ plots and characteristic understorey species

Box-Herb

Grassy White

Pine-Ironbark (1)

Grassy White

Pine-Ironbark (2)

Riparian

Angophora-Red

Gum

Grassy White

Pine-Box

Heathy

Bloodwood-

Ironbark (1)

Heathy

Bloodwood-

Ironbark (2)

Heathy

Bloodwood-

Ironbark (3)

Heath
66 E. populnea (51), C.glaucopbylla (92), Allocasuarina luehmannii (92), Myoporum montanum (78), Oxalis perennans (87), Enchylaena tomentosa (77), Geijera parriflora (77), Enteropogon acicularis (75)

67 E. crebra (88), C. glaucophylla (89), Allocasuarina Iuehmannii (92), Eragrostis lacunaria (86), Austrodanthonia bipartita (56)

66 C. glaucophylla (87), E. crebra (68), Cheilanthes sieberi (98), Stackhousia muricata (72), Digitaria diffusa (65)

39 Angophora floribunda (74), E. blakelyi (66), Hypericum gramineum (58), Ajuga australis (53), Wablenbergia planiflora (74), Chrysocephalum apiculatum (64)

34 C. glaucophylla (82), E. albens (26), E. conica (17), Austrodanthonia racemosa (70), Vittadinia dissecta (73), Vittadinia muelleri (61), Calotis Lappulacea (61), Senecio quadridentatus (58)

47 C. endlicheri (53), Corymbia trachyphloia (48), Persoonia sericea (87), Dodonaea viscosa (65), Hibbertia obtusifolia (85)

12 Corymbia trachyphloia (76), E. fibrosa (63), Allocasuarina

6 diminuta (69), Pomax umbellata (80), Calytrix tetragona (79), Schoenus ericetorum (58)

26 E. fibrosa (84), Corymbia trachyphloia (69), Goodenia motundifolia (88), Gonocarpus elatus (80), Pbilotheca ciliata (57)

9 Melaleuca uncinata (88), Cryptandra amara (88), Calytrix tetragona (100), Gonocarpus elatus (88), Melaleuca erubescens (55)

There is a clear geographical pattern in the distribution of floristic groups (Figure 1). Although detailed analyses of the floristic groups in relation to 
physical environment has not been carried out, the pattern is likely to be most strongly related to geomorphology (from elevated sandstone landscapes in the east to flat, depositional landscapes in the west) and climate (particularly the rainfall gradient). Disturbance history, particularly fire history, may also be important, but relationships are confounded by strong feedback interactions (fire spread is facilitated by the fuel structure in heathy vegetation) and history of fire suppression (suppression efforts are less intense in heath forests and woodlands due to lower commercial value). The only group which does not display a clear geographical pattern is the Riparian Angophora-Red Gum group, which is associated with larger stream channels through most of the area, except in the western part where there are no large stream channels and drainage channels generally are poorly differentiated. The broad scale patterns suggested by this analysis partly reflect the fine-scale patterns related to geomorphological features and soil properties described by Humphries et al. (Chapter 9, this volume), but partly also suggest the influence of other factors such as climate at a broad scale.

Table 2. Mean native and exotic species richness per plot in each floristic group, and percentage of plots containing at least one exotic species.

\begin{tabular}{lccc}
\hline Floristic group & \multicolumn{2}{c}{$\begin{array}{c}\text { Mean number of species } \\
\text { per plot }\end{array}$} & $\begin{array}{l}\text { Proportion } \\
\text { of plots } \\
\text { with exotic } \\
\text { species (\%) }\end{array}$ \\
\cline { 2 - 4 } Box-Herb & Native & Exotic & 3.0 \\
Grassy White Pine-Ironbark (1) & 45.3 & 1.5 & 61 \\
Grassy White Pine-Ironbark (2) & 39.2 & 1.6 & 77 \\
Riparian Angophora-Red Gum & 43.5 & 5.0 & 95 \\
Grassy White Pine-Box & 46.6 & 8.4 & 100 \\
Heathy Bloodwood-Ironbark (1) & 51.8 & 1.1 & 70 \\
Heathy Bloodwood-Ironbark (2) & 41.9 & 0.6 & 39 \\
Heathy Bloodwood-Ironbark (3) & 44.0 & 0.3 & 23 \\
Heath & 34.8 & 0.3 & 33 \\
\hline
\end{tabular}

On a sample plot basis (Table 2), the Grassy White Pine-Box group has the highest floristic richness of native species, significantly $(p<0.05$, Tukey's test) higher than all other groups except Riparian Angophora-Red Gum. However, it also has the highest number and percentage of exotic species, significantly higher than all other groups. This group occurs on basalt substrates or in areas where the soil has been enriched from adjacent areas of basalt. The Riparian Angophora-Red Gum group and the Box-Herb group are next highest in floristic richness per plot, but the difference between 
these and most other groups is not statistically significant. The floristic richness of the Heath group is significantly lower than most other groups. As a measure of the total flora of each group, the cumulative native species richness (Figure 2) shows generally similar trends to the result on a plot basis, with the notable exception that the Riparian Angophora-Red Gum group has the highest number of native species overall. Of the remaining groups, the Grassy White Pine-Box has the highest cumulative number of species.

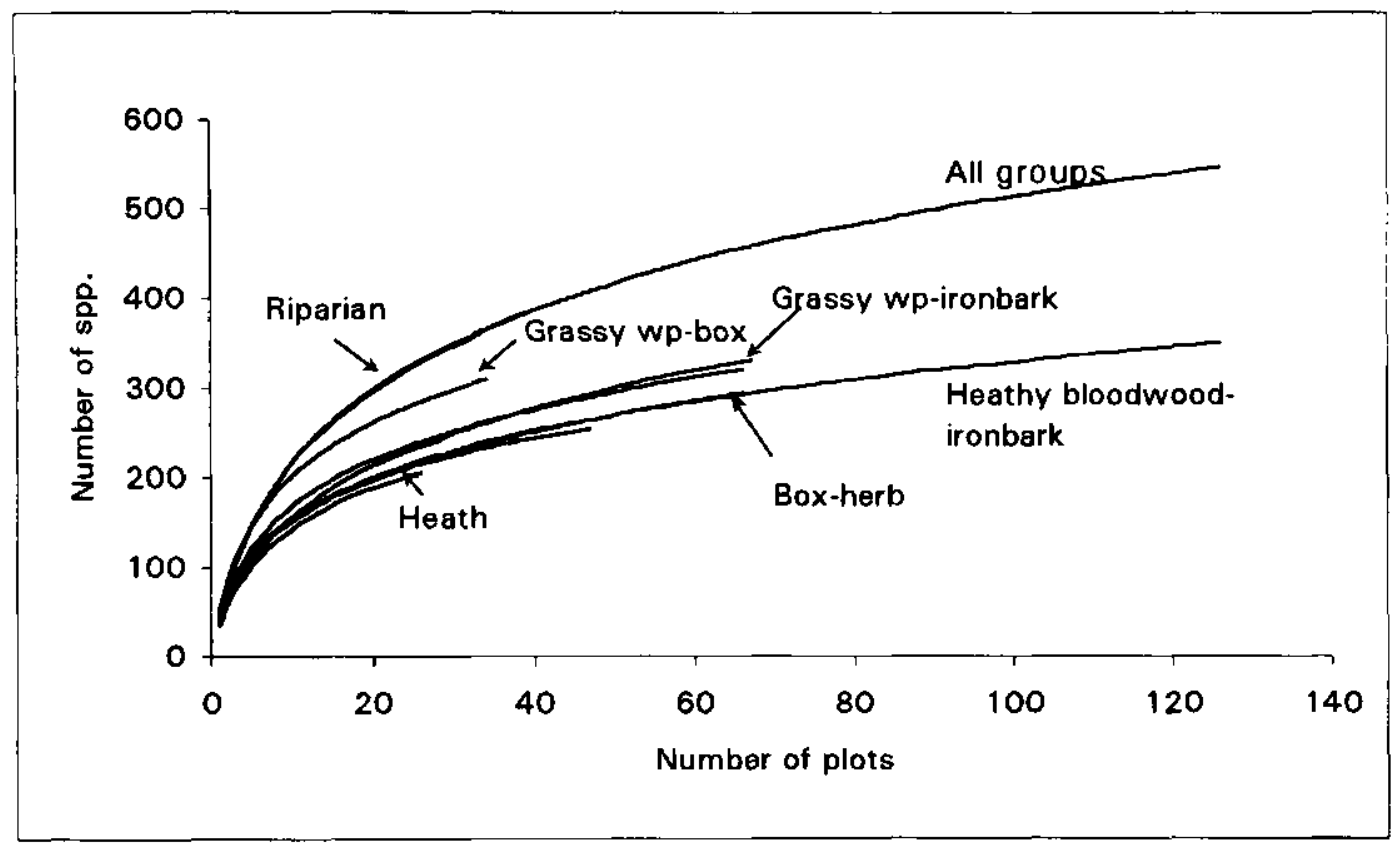

Figure 2. Cumulative number of native species for each floristic group.

Table 3. Frequency of occurrence of Callitris species in each floristic group. Superscripts indicate relative degree of statistical significance (Wilcoxon rank sum test) of occurrence in each group, from strongly positive association $(++)$ to strongly negative association $(--)$.

\begin{tabular}{lcc}
\hline Floristic group & C. glaucopbylla & C. endlicheri \\
\hline Box-Herb & $92++$ & $0--$ \\
Grassy White Pine-Ironbark (1) & $89++$ & $7-$ \\
Grassy White Pine-Ironbark (2) & $87++$ & 25 \\
Riparian Angophora-Red Gum & 35 & $51+$ \\
Grassy White Pine-Box & $82+$ & 8 \\
Heathy Bloodwood-Ironbark (1) & $14-$ & $53+$ \\
Heathy Bloodwood-Ironbark (2) & $34-$ & $46++$ \\
Heathy Bloodwood-Ironbark (3) & 50 & 11 \\
Heath & 33 & \\
\hline
\end{tabular}




\section{Conclusion}

Floristic patterns in the forests and woodlands of the Pilliga area may be described in nine major floristic groups. There is a strong geographical pattern in the distribution of these groups, most likely primarily related to geomorphology and soil properties, and climate (especially rainfall). The two main species of Callitris are a prominent feature of the vegetation. They occur across all (white cypress pine) or most (black cypress pine) floristic groups, although they are strongly negatively associated with each other and each characterises a different set of groups.

\section{References}

Bedward, M., Keith, D.A. and Pressey, R.L. 1992. Homogeneity analysis: assessing the utility of classifications and maps of natural resources. Australian Journal of Ecology 17: 133-9.

Belbin, L. 1995. PATN Pattern analysis package reference manual Canberra: CSIRO Division of Wildlife and Ecology. 


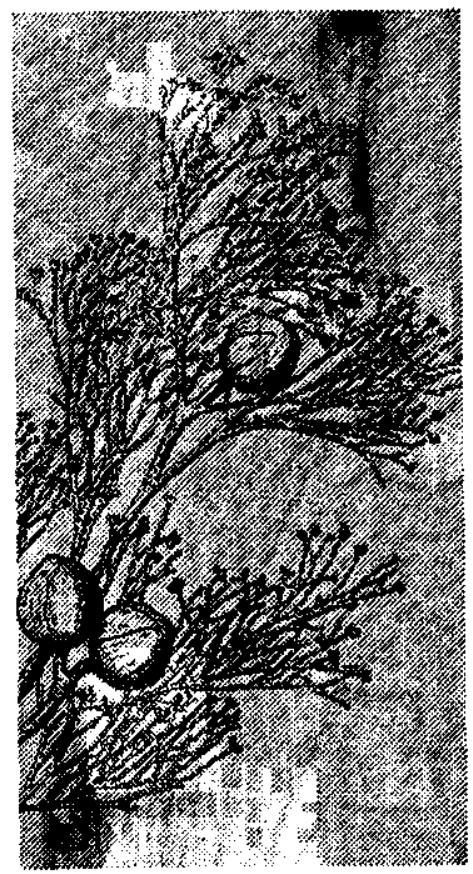

\section{4}

\section{The 'frontier':}

\section{Callitris intratropica and landscape change}

\section{David Bowman}

All the aborigines have been removed to an island in Bass's Strait, so Van Diemen's Land enjoys the great advantage of being free from a native population. This most cruel step seems to have been quite unavoidable, as the only means of stopping a fearful succession of robberies, bumings, and murders, committed by the blacks; but which sooner or later must have ended in their utter destruction. I fear there is no doubt that this train of evil and its consequences originated in the infamous conduct of some of our countrymen. Thirty years is a short period, in which to have banished the last aboriginal from his native island-and that island is nearly as large as Ireland. I do not know a more striking instance of the comparative rate of increase of a civilized over a savage people.

Charles Darwin (1839) Voyage of the Beagle.

A powerful underlying message in the above disturbing observations made by Charles Darwin concerns his absolute certainty of biological and sociological processes set in train by European colonization of Australia. Some hundred and sixty years later, settler Australians are much less certain about their future and their ongoing relationship with both Aborigines and Australian landscapes. Indeed, how Aborigines managed land and the negative ecological consequences that have followed European colonization have become vexed questions in current scientific, political and environmental debates. This is particularly the case concerning the impact of Aboriginal 
landscape burning on the Australian biota and the ecological consequences of the cessation of this management practice.

Despite a number of popular books that confidently address these matters it is surprising how little is known about Aboriginal fire usage in the near or more distant past and virtually nothing is known about the fire usage by the first colonists some 50000 years ago (Bowman 1998). In this context the recent studies of the ecology of Callitris intratropica have provided important insights into the ecological effect of Aboriginal landscape burning in northern Australia.

\section{Callitris intratropica: message trees from times past}

There are a number of reasons why Callitris intratropica is an ideal species to study changes in Aboriginal fire usage (Bowman and Panton 1993). The first is that Callitris intratropica has a relatively long life span of up to 250 years (Hammer 1981). Therefore most mature trees of this species have experienced the transition from traditional to post-traditional landscape practices that followed European colonization of northern Australian. Secondly, Callitris intratropica is widespread throughout the monsoon tropics typically occurring in small patches within an Eucalyptus savanna matrix. The species grows in a wide range of landscape settings and most soil types, with the exception of heavy clay soils. Given its tolerance to water stress and infertile soils, its heavily fragmented distribution throughout its range, is at first glance puzzling. However this apparent paradox is explained by its relative fire sensitivity. Although the trees are tolerant of low intensity fires they are damaged and ultimately killed by high intensity fires. Seedlings, however, have virtually no tolerance of fire and are eliminated from all sites that are burnt annually. Conversely, the absence of fire allows the species to continuously recruit seedlings resulting in very heavily stocked stands because of very limited density dependent mortality.

The wood of Callitris intratropica is termite resistant because it is impregnated with a diversity of toxic biochemicals. Settlers quickly learnt to prize the timber because it was one of the few locally available trees that could resist the remarkably destructive wood eating termites that are endemic to the Australian monsoon tropics. Much of the northern half of the overland telegraphy was made from Callitris intratropica poles before being replaced by steel poles. In the 1950s and 1960s the Commonwealth Government recognized the importance of Callitris intratropica to the economy of the Northern 
Territory. The Commonwealth established a number of pure and applied forestry research projects designed to develop both plantation and native silvicultural based industries in the Northern Territory. Despite the failure of these industries the forestry research programs into Callitris intratropica have contributed more knowledge about this species than any other tree species in the monsoon tropics. This knowledge base is critical for developing mathematical models of the demography of the species used to explore the consequences of changed landscape fire regimes. The second reason why the termite resistant timber is of great significance for studies of landscape change is that, unlike nearly all other species, Callitris intratropica trees remain in the landscape after they have died. The presence of dead Callitris intratropica stems enables ecologists to look 'backwards' and detect changes in the distribution of the species. The significance of large areas of dead Callitris intratropica is not lost on some Aboriginal people. Haynes (1985), for instance, reported traditional owners in central Arnhem Land as recognizing dead Callitris intratropica stands as evidence that 'country' was not being properly managed.

Traditional Aboriginal fire regimes are thought to have been characterised by numerous low intensity fires, while large-scale high intensity fires are more typical of contemporary European land management. Bowman and Panton (1993) explained high densities of dead Callitris intratropica stems throughout the Top End of the Northern Territory as a consequence of the transition from Aboriginal to European fire management. Mathematical modelling undertaken by Price and Bowman (1994) further supported this finding. Yibarbuk et al. (in press) found that in an area surrounding an Aboriginal outstation in central Arnhem Land Callitris intratropica was a relatively common tree on sites without topographic fire protection (i.e. sandsheets).

These above views have recently been supported by recent studies designed to compare landscapes that are still inhabited by Aboriginal people with those that have become unoccupied (Bowman et al. submitted). These authors demonstrated that in areas where Aboriginal people still live the proportion of dead Callitris intratropica stems is less than in environmentally similar areas that have become 'wilderness' due to depopulation in the last 50 years. However, this generalisation requires qualification as their study showed that the abundance of Callitris intratropica and the proportion of dead stems varies between different landscape settings, being most abundant in landscapes where Allosyncarpia ternata closed forests are common. Allosyncarpia ternata like Callitris intratmpica is a relatively fire sensitive tree and is typically restricted to sites with topographic fire protection such as canyons, 
rocky areas and creeklines and only occasionally occurs on level terrain (Russell-Smith et al. 1993).

Bowman et al. (submitted) developed a mathematical model based on data collected from a single stand of Callitris intratropica adjacent to a patch of Allosyncarpia ternata on a sandsheet in an area currently unpopulated by Aboriginal people. The results of the modelling also emphasised the need to qualify the conclusion that increased fire frequency associated with the cessation of Aboriginal land management necessarily results in the localised extinction of Callitris intratropica. The modelling revealed that populations can persist, albeit with much lower densities than under optimal fire regimes, if the mortality of smallest size classes is less than 70 percent. Furthermore, such depressed populations have the potential to recover rapidly if the mortality of the smallest size class was reduced. Thus the populations of Callitris intratropica can fluctuate in response to various fire regimes within the maximum life span of Callitris intratropica trees, which is about 250 years. In sum, it is unlikely that changed fire regimes will greatly effect the geographic range of Callitris intratropica in the monsoon tropics but they can strongly influence the abundance of different size classes of populations across the landscape.

There is no question that Callitris intratropica is a powerful bio-indicator of landscape change in the monsoon tropics following the cessation of Aboriginal landscape burning. However, Bowman et al. (submitted) have shown that predicting the fate of individual populations requires careful consideration of local factors such as the presence of micro-topographic safe sites for seedling establishment and the nature of the surrounding vegetation mosaic. Such information will be difficult to obtain and difficult to transfer to other landscape settings. Rather than obsessing over the minutiae of details required to make models faithfully mirror the workings of real forests, it would be more appropriate, given the rate and magnitude of landscape changes wrought by European fire regimes, to shift the focus of research to other organisms. Of particular concern are relatively short-lived organisms that live in small fragmentary populations, such as insects such as the Leichhardt grasshopper (Petasida ephippigera) and mammals such as the native cat (Dasyurus ballacatus).

\section{Reflections on the meaning of dead pines}

Callitris intratropica literally straddles the boundary between traditional Aboriginal and European land management regimes. In many other landscapes in Australia this 'frontier effect' has receded into the historical past. 
Extracting a coherent message from landscapes about the changes wrought by Europeans becomes more difficult in direct proportion to the time elapsed since the frontier developed. A good example of this problem is the Pilliga Scrub, which is a palimpsest of poorly documented European land management interventions overlaid upon a complex and largely unknown Aboriginal cultural landscape. Even the meaning of Aboriginal names for basic landscape features are lost. For instance the local term 'sand monkey' used to describe palaeo-river channels is thought to be derived from a word in a local Aboriginal language, but specific details of this derivation are unclear.

Given the rapid loss of cultural knowledge from so many Australian landscapes we are forced to puzzle over the past-we can never know sophisticated details like how and why country was burnt. Clearly the receding frontier and associated loss of certainty presents both practical and psychological problems for settlers.

On frontiers the only certainty is change itself-in one or two generations heroic, vital and purposeful frontier lifestyles can be reduced to pathetic, marginal lives, as is powerfully portrayed in Arthur Miller's The Misfits. With calculated irony Miller (1961) has some of the last of the wild west 'cowboys' eking out a living killing wild horses for pet food. Large areas of rural Australia are now afflicted by a similar sense of loss as the economic fortunes of the 'frontier' have passed them by. Darwin's sense of manifest destiny has now been replaced by manifold despair.

Imperfect knowledge of the nature of the bewildering changes that have occurred on the frontier has rendered most scientists impotent in satisfying the immediate needs of land managers charged with 'managing' environmental change. In any case, land managers typically can not clearly state their objectives with the result that scientists are often uncertain as to what scientific products land managers want. For example, debates about how best to manage forests like Pilliga Scrub can become endless conversations that are like the end of a frayed rope-something concrete that gradually disappears into an ambiguous void.

In this context there is a great temptation to develop 'grand narratives' that fill the disturbingly empty past with comforting certainty. I suspect the popular success of narratives such as The Future Eaters and $A$ Million Wild Acres probably reflects the fact that these works help resolve psychological problems that afflict both urban and rural settler Australians, rather than because of any inherent scientific veracity.

I believe both historical stories and scientific certitude are required to make sense of one's place in landscapes and to manage environmental 
change. However, I suggest it is unrealistic to expect complete sense to be made of the momentous ecological and social implications of the passing of the frontier. Rather, a sense of place and a sense of control can only be achieved by much hard work by many generations of historians and scientists. Grand narratives are important points of departure in these quests but must not be read as having the finality of the terminus.

I have no doubt that ecology studies of long-lived species such as Callitris intratropica can shed light on the ecological changes that followed the transition from Aboriginal to European land management. Such knowledge helps us comprehend a fraction of the complexity of this transition and can help in the formulation of land management interventions. Further, 'ecohistorical' approaches are powerful because they can potentially unite the 'two cultures' of the historical with the ecological modes of analysis.

\section{References}

Bowman, D.M.J.S. 1998. Tansley Review No. 101: The impact of Aboriginal landscape burning on the Australian biota. New Phytologist 140: 385-410.

Bowman, D.M.J.S. and Panton W.J. 1993. Decline of Callitris intratropica R.T. Baker \& H.G. Smith in the Northem Territory: implications for pre- and post-European colonization fire regimes. Journal of Biogeography 20: 373-81.

Bowman, D.M.J.S., Price, O., Whitehead, P.J. and Walsh, A. (submitted). The 'wildemess effect' and the decline of Callitris intratropica on the Amhem Land Plateau, northem Australia. Australian Journal of Botany

Darwin, C. 1839 Voyage of the Beagle, cited in Browne, J. and Neve, M. 1989. Voyage of the Beagle: Charles Daruin's Joumal of Researches. Melbourne: Penguin Books.

Flannery, T.F. 1994. The future eaters: an ecological bistory of the Australasian lands and people. Sydney: Read Books.

Hammer, G.L. 1981. Site classification and tree diameter-height-age relationships for cypress pine in the Top End of the Northem Territory. Australian Forestry 44: 35-41.

Haynes, C.D. 1985. The pattern and ecology of munwag. traditional Aboriginal fire regimes in north-central Amhem Land. Proceedings of the Ecological Society of Australia 13: 203-14

Miller, A. 1961. The mifits. New York: Viking Press.

Price, O.and Bowman, D.M.J.S. 1994. Fire-stick forestry: a matax model in support of skilful fire management of Callitris intratropica R.T. Baker by north Australian Aborigines. Joumal of Biogeography 21: 573-580.

Rolls, E. 1981. A million wild acres. Melbourne: Penguin Books

Russell-Smith, J., Lucas, D.E., Brock, J. and Bowman D.M.J.S. 1993. Allosyncarpiadominated rain forest in monsoonal northern Australia. Journal of Vegetation Science 4: 6782.

Yibarbuk D., Whitehead, P.J., Russell-Smith, J., Jackson, D., Fisher, A., Cooke, P., Choquenot D. and Bowman D.M.J.S. (in press). Fire ecology and Aboriginal land management in central Anhem Land, northem Australia: a tradition of ecosystem management. Journal of Biogeography. 


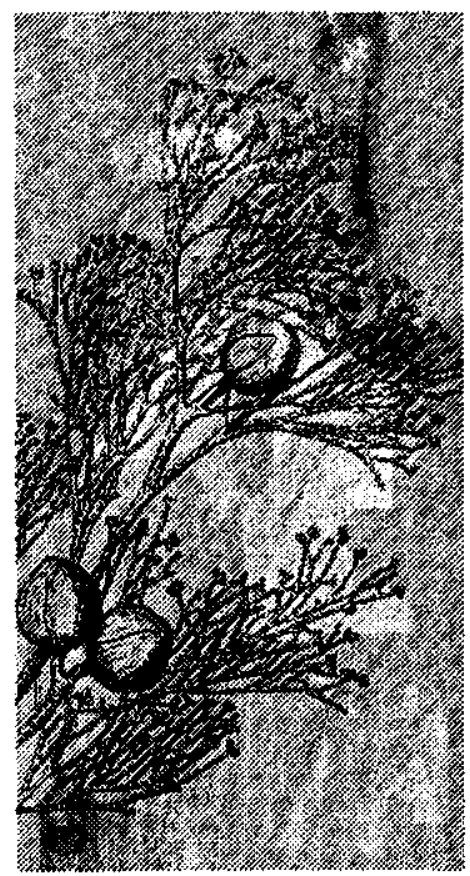

\section{5 \\ Perfumed pine and the pioneers}

\section{Bob McKillop}

This chapter examines the historical context of white cypress pine as the building material of the pioneer European settlers who shaped today's Orana Region. It is part of a wider work in progress, which seeks to interpret the economic, social and environmental history of Orana Region-the vast area of north-western New South Wales shaped by the Castlereagh, Macquarie and Bogan River systems.

The history of European settlement in the region commences with the opening of the first track across the Blue Mountains, which broke through the Great Dividing Range that had restricted the activities and visions of the early colonialists at Sydney. Once beyond the reach of colonial power and authority, squatters rushed to take control of the new lands, which offered new pastures for livestock. In doing so, they displaced the existing inhabitants and established vibrant communities free of the inhibitions and barriers of the societies they left behind. But they found the new lands to be harsh and inhospitable. The knowledge and beliefs they had brought with them from the old countries provided comfort and guidance in dealing with the unknown, but limited understanding of how to cope with the new environment. This account focuses on the Dubbo and Narromine districts. Early squatters in this area included Robert Dulhunty, who established Dubbo Station in 1832, and W.C. Wentworth and Captain Raine who took up 
Narramine Station by 1835 , while Robert Smith claimed the adjacent Timberrybunan Run (later Timbrebongie) around this time.

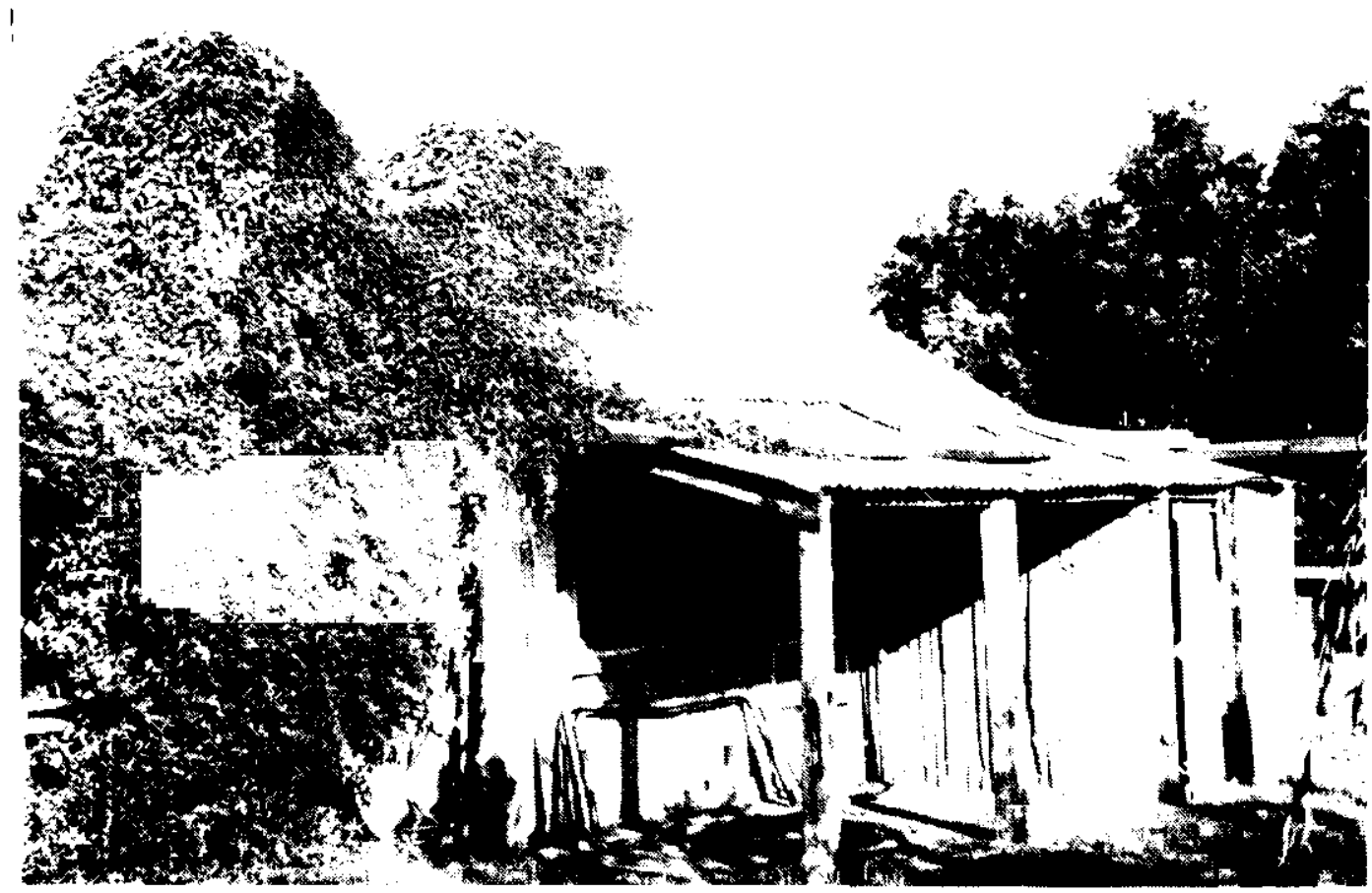

Figure 1. Shepherd's hut at Buddah 1977 (Photo. Desmond Kennaird).

\section{Squatter's shelter}

Shelter was a dominant need of the pioneer settler. Primitive slab-walled, bark-roofed huts were the most common form of dwelling for squatters and their shepherds alike in the early years. On the Western Plains, the quality of white cypress pine soon made it a preferred timber for even the simplest hut. One such hut still stands adjacent to the Buddab Hall homestead beside the Macquarie River, 20 kilometres north of Narromine. It was originally erected on the extensive Timbrebongie Run as a shepherd's hut, probably in the 1850 s. It was relocated to the Buddab homestead in the 1880 s for servants' quarters. Additional comforts, including a fireplace, glazed windows and a corrugated iron roof were added. The hut stood unused for many years after 1920. Recently, the Narromine Shire Council Heritage Adviser has negotiated with the University of New England for students to carry out a Conservation Management Plan of the old hut. The students will find original pine slabs and round poles in the roof, with bark remaining in sections under the roofing iron. 


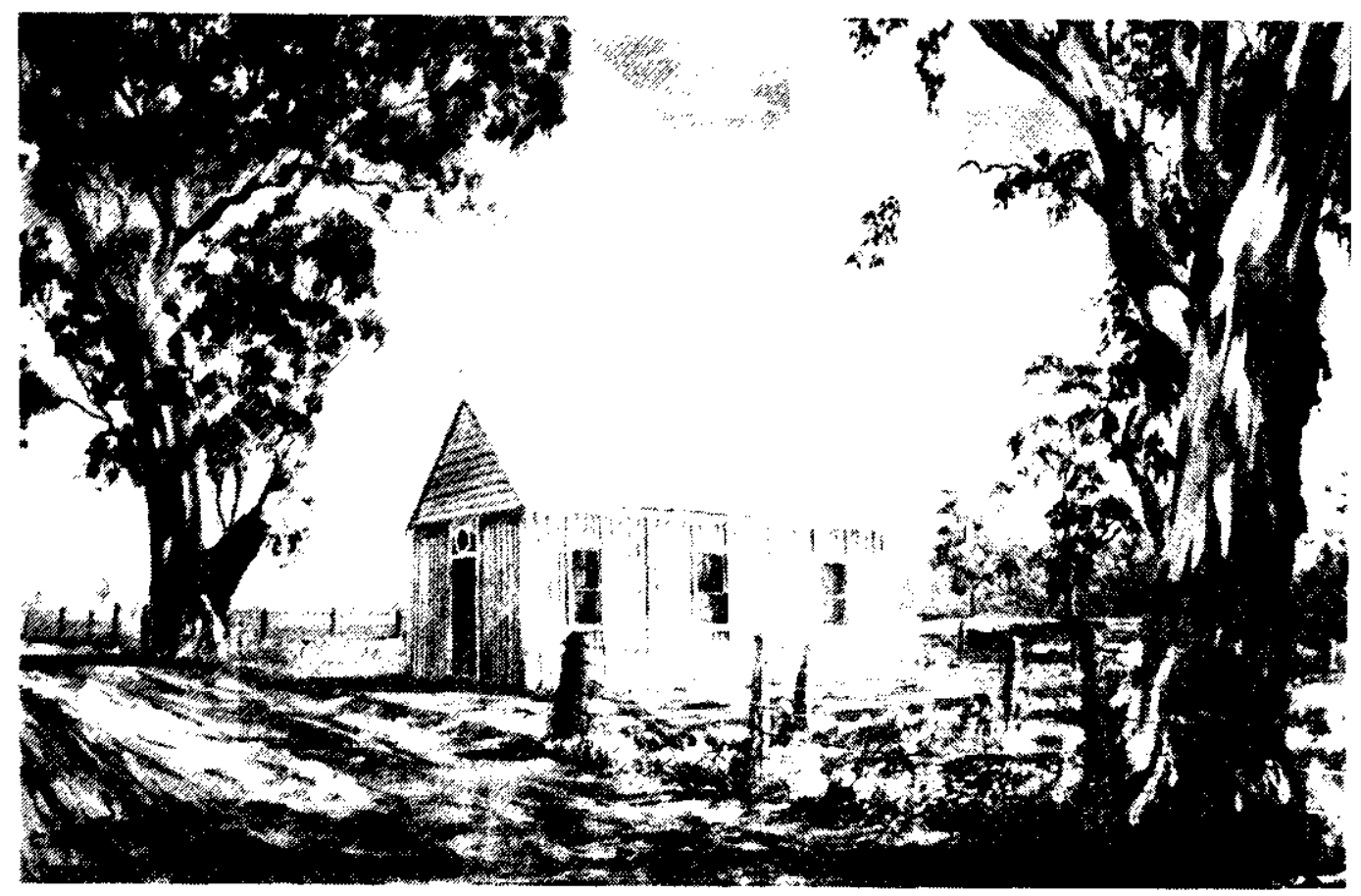

Figure 2. Former Timbrebongie Church at Buddah c.1970 (Painting by Greg Brennan: McKillop Family Collection)

Western white cypress pine soon gained a reputation as the preferred timber for buildings throughout much of the region. When sawn it was honey-coloured with beautiful amber figures in it and the high resin content made it termite-proof. There are many references in early newspapers to the neatness and beauty of pine buildings. When the French author Marian La Meslee visited William O'Neill's inn at the future site of Narromine in September 1880, he commented on the neatness of its pine timber (Burgess 1995 , p.74). A report on the gold-mining village of Tomingley in 1883 commented that the availability of pine timber meant that 'the buildings are more substantial than the common bark humpy of the generality of rushes' (Sydney Mail, 21 April 1883, p. 742).

The simple construction of the shepherd's hut contrasts with the more ambitious Buddab homestead built by squatter John Dargan around 1858 on the levee banks of the Macquarie River (McKillop 1956, p.24). Large quantities of pine were pit-sawn for the task. Itinerant workers would have been hired for the sawing and building tasks. The 'top-sawyer' was among the most highly regarded of the bush artisans (Cannon 1973, p.86). He and his mate would locate a stand of suitable timber, camp there, dig a hole for the sawpit, fell the trees and saw the timber into planks. For this latter task, the 'pit boy' worked the two-handled saw from under the log, with the 'topsawyer' guiding the process from above. As the saw cut on the downstroke, 
the 'pit boy' worked in streams of sawdust (Rolls 1981, p.272). He kept his eyes cast downwards to protect them and usually wore a long veil. Sufficient pine trees were felled to construct a fine homestead overlooking the River.

Buddab homestead was erected using hand-made iron nails, which remain in place today. Timber shingles were used for the roof, while glazing glass, door locks and furniture were brought by bullock wagon from the coastprobably from Maitland or Morpeth-for the house. Unfortunately, some panes of glass were broken during the journey, but the difficulty of obtaining replacements meant they were fitted around the main entrance door anyway. The broken panes remain to this day. The homestead was significantly altered in 1920, with a brick extension on the northern side away from the river creating a new entrance to the house, and a detached kitchen and servants' quarters to the east and a cottage to the west, also in brick, changing the character and aspect of the house. However, the original pine homestead remains at the core of the building and creates the sense of place that identifies the heritage significance of the structure. The cypress flooring in the verandah that is now at the rear of the house still retains most of its original pit-sawn boards and hand-made nails, while the core framework and most of the wallboards have not been touched since the day they were erected. The homestead was heritage listed by the National Trust in the 1970s.

The other important buildings of the squatter era were churches and woolsheds. The role of religion on the frontier is illustrated through the history of the Timbrebongie church. It was constructed from solid planks of white cypress pine in the Cobb \& Co coaching village of Timbrebongie, probably in 1872, when Colin Crisp Lode first held a Catholic service there (Jean McKillop records). The Rev. Holland reconsecrated the building as a Presbyterian church on 2 September 1888 , possibly on a new site. When the railway bypassed Timbrebongie in 1882, the village gradually declined as the new raikway town of Narromine emerged as one of the major wheat growing centres of New South Wales in the early 1900s. The church was moved to Buddah station in 1910, where it served as a Presbyterian place of worship for families from surrounding properties until the 1970s (Narromine News, 27 February 1980). The writer was christened there in 1941 and his sister married there in 1968. In February 1980, the church was again moved, this time to Narromine where it has been established in a local caravan park as a historic icon. The pine planks are still in excellent condition. The park owners have provided an interpretative history of the church, which is now used as a communal centre for visitors. 
The Buddah woolshed, until recently, represented the role of perfumed pine in the industrial heritage of the squatter age. This fine building was designed and built by George McKillop (Junior) in 1908, but used cypress pine timber recycled from the old Buddab Lake woolshed. The date this early structure was erected is unknown. The high roof over the pressing floor to accommodate the woolpress gave the building an unusual and distinct character. It was a 10-stand shed equipped with the then latest Wolsely machines, which were driven by a Hornsby oil engine (Pastoral Homes of Australia, p. 413). Under-cover protection was provided for a large number of sheep in case of rain. The Buddab woolshed was placed on the Register of the National Trust in 1973 and was listed as a heritage item under the Narromine Shire Council Local Environment Plan. Unfortunately, it was demolished in 1997 to make way for expansion of irrigation areas for cotton.

The impact of timber cutting on the pine forests of Orana during the squatter era was limited. The scattered settlers took only the trees for their immediate building requirements. But their impact on the overall vegetation of the region was much more significant. Their introduced grazing animals, timber clearing and altered fire regimes altered the ecology of the region in an unpredictable manner. Eric Rolls has documented how displacement of regular burning by Aborigines through pastoral pursuits stimulated a massive regeneration of pine in the Pilliga. Similar stories emerged throughout the north-west pastoral district-when wildfire and Aboriginal firestick farming ceased to maintain the grazing rangelands by suppressing shrubs, and overgrazing by introduced livestock removed native grasses, cypress pine and several species of other native woody weeds quickly established their dominance. When members of the Bragg family took up selections on the former Narramine pastoral run along the Great Western Railway in 1884, they found the land 'so thickly timbered that, as the saying goes, a dog couldn't bark in it.' (Pastoral Homes of Australia 1929, p.421).

\section{Railway and agricultural era}

The railway had a dramatic impact on the way the settler interacted with his environment. Beyond Dubbo, the ribbons of steel marched confidently in a direct line to the Darling at Bourke. The Great Western Railway bypassed the existing settlements of the coaching routes and created new townsNarromine, Trangie, Nevertire, Nyngan, Coolabah and Byrock-and it provided the opportunity for agriculture to take root on the rich inland plains. It also stimulated indiscriminate exploitation of forest resources. 
For the railway itself, sleeper cutters plundered the ironbark forests to lay the foundations for the 'iron horse', and white cypress pine created the railway stations and houses for their staff. Narromine railway station, opened in 1883 some six months after the railway, was the first permanent building in the town and it became the centre of economic activity. The village of Varromine was not surveyed until February 1883 and the first lots of land were sold in May 1884. Narromine railway station was listed on the Register of the National Estate as an item of heritage significance in the 1980s. The community has faithfully restored the station as its most significant heritage place. While some sections of the building were badly decayed, the majority of the pine remains in sound condition.

The new towns created by the railway stimulated local building booms, which required good building timber. In addition, the railway enabled pine to be economically trucked to more distant markets. The milling of white cypress pine provided the initial economic stimulus for the settlement of Trangie. A 'powerful sawing plant' was in operation there by 1884 and there were three mills sending away large quantities of sawn timber by rail by 1886, while Mr John Campbell was dispatching trucks of pine logs on a daily basis to mills at Orange (Warren Brennen collection).

Selectors soon flocked to take up good wheat-growing land along the railway line, clearing the trees for their crops and generating prosperity for the rapidly growing towns. To the new settlers, trees were a nuisance as they hindered soil preparation, competed for scarce soil nutritients and moisture, and cast shadows on the crops. They cleared the pine and eucalypts, using some of the timber for their huts and fences. By 1896, Narromine was rapidly establishing a reputation as an important wheat-growing district, with some 20000 acres under wheat in the district, including 2000 acres belonging to Mack and Austin on Narramine Station and 1000 acres on Bragg Bros. properties (Freman's Journal, 1896).

Soon the success of wheat farming at Narromine attracted a flood of families seeking land and the opportunity to engage in agriculture. One such selector was Marquis Reakes, the son of an English gold miner at Tomingley, who won the ballot for a homestead selection, Portion 187 of the old Narramine Station at Dubbo in February 1901 (Narromine News, 8 February 1901). With the assistance of his brother Walter, Marquis set about clearing the cypress pine and box trees on the 600 acre block they called Brooklyn. By 1906, Marquis was able to move his wife, Lena, and three children into a log cabin on the block. As the green pine logs (probably black cypress) dried, the cracks let in the cold winds (Ivy Reakes 1920). The family mixed mud and plastered it over the cracks. 


\section{Towards forest management}

Soon the ruthless clearing and exploitation of the forest for timber and agriculture generated alarm. When Mr. Martin, the first forest ranger, arrived at Dubbo in March 1882, it was claimed that:

The wholesale destruction of valuable timber has, during the past few years, been positively disgraceful. Regulations and Acts have been treated as dead letters. The young growing pine has been ruthlessly chopped down, and the hardwood such as ironbark, gum, etc used up and wasted. Sawmills have been at work in the middle of our best forests, never paying royalty or anything else. Timber reserves have been made, but with that crossness peculiar to red tape, they have been proclaimed where no timber existed. The real timber-getting country, which is usually neither good for grazing nor agriculture, has not been reserved, and as a consequence for 30 to 40 miles around the land has been completely denuded of timber of any commercial value.

Sydney Mail, 18 March 1882, p.42

Gradually Martin and his superiors were able to bring the situation under control through the declaration of forest reserves and licensing of mills. They were assisted by a shift in public values with respect to building materials. While the colour, character and termite resistance of 'yellow wood' were much admired, its one big drawback was the flammability of its resins. Major fires in Western towns, such as those in Warren and Narromine in 1899 , were significant factors influencing a shift to other materials. Eleven businesses and residences in the block of buildings at Narromine known as 'The Arcade' were totally destroyed by fire on 1 March 1899. The local newspaper noted that 'most, if not all, the buildings are constructed of wood, and that wood perhaps the most inflammable of any colonial timbers, for pine seems to fairly reek with resin; a lot of it, even though small, being very hard to quench once fairly lit up.' (Narromine News, 3 March 1899). The following November, what was described as 'one of the most destructive fires that has ever occurred in an inland town in this colony' destroyed nearly half the town of Warren (Town \& Country Journal, 2 December 1899, p.15). Businesses and wealthy residents increasingly turned to bricks for the construction of their buildings from the turn of the century.

Over the years a sustainable forest management system has evolved for the Western forests that contain significant quantities of cypress pine. At the same time, there has been a resurgence of interest in the qualities of white cypress pine timber. That interest is reinforced by the heritage of the fine buildings constructed by the pioneer European settlers using this timber that 
have survived to this day. This paper describes some of these buildings and invites further study of other equally worthy examples of 'Perfumed Pineries and the Pioneers'.

\section{References and sources}

Burgess, Neville 1995. The great Cobar, self-published.

Cannon, Michael 1973. Life in the country. Melboume: Thos. Nelson.

Freeman's Journal, September 1896, 'A tour of the west: From Narromine to Nyngan'.

McKillop, Ainslie 1956. 'The McKillops of Buddab: their history briefly from 1811 to 1951 '. roneo mss.

Pastoral bomes of Australia 1929, vol.1.

Reakes, Ivy Ruth 1920. 'A weed grew on Brooklyn'. Mss. found among family papers in 1996. Rolls, Eric 1981. A million wild acres: 200 years of man and an Australian forest. Melbourne: Thos. Nelson.

The Narromine News of Trangie Advocate, 1889-1980.

The Sydney Mail, 1880-90.

Town e' Country Journal, 1880-90.

Warren Brennen collection, Warren Library, 'Notes from Trangie', press cutting 1886. 


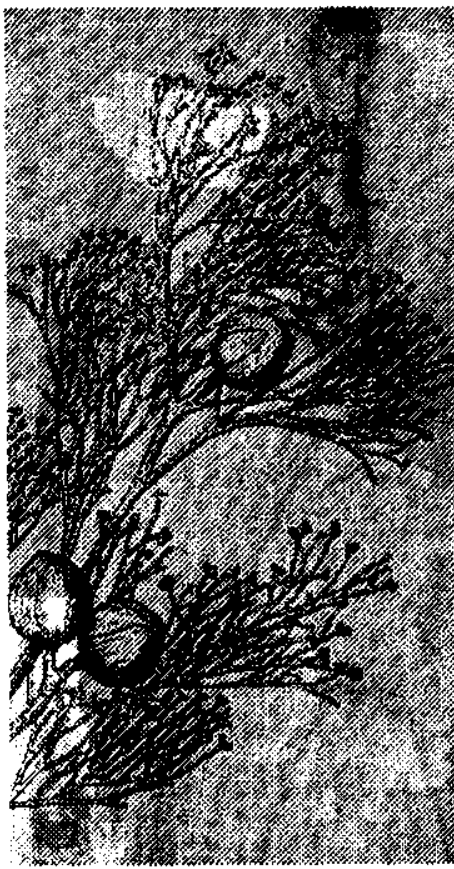

\title{
Recent disturbances to Callitris forests in Southern Queensland
}

\author{
Mark Harris
}

and David Lamb

\section{Introduction}

The white cypress pine (Callitris glaucopbylla) forests of Queensland and New South Wales are very different in structure and appearance from those seen by early European settlers. Agricultural clearing has reduced much of this widely distributed forest type to a mere remnant of its original distribution (Forestry Commission of NSW 1988). Other disturbances over the last 100 years have also caused significant ecological changes to the distribution, spatial patterns and the frequency of regeneration of cypress pine in these forests. White cypress pine now occurs as scattered trees or in small forested areas across much of its former range (Lacey 1973).

In this paper we briefly describe the habitats currently occupied by cypress pine and review some of the environmental changes affecting its distribution and regeneration that have occurred over the last 100 years. The disturbances affecting cypress can be placed into two broad categories: those caused by climatic variation, such as drought and above-average rainfall; and those that are human induced, such as disruption of the natural fire regime and the introduction of exotic flora and fauna. 


\section{Natural occurrence of cypress pine in Queensland}

In Central and Western Queensland white cypress pine occurs in varying densities and may occur in pure stands or mixed with various eucalypts depending on soils and topography. The better stands are usually found on light textured, well-drained soils ranging from deep sands to shallow duplex solodic or solodised solonetz soils (Johnston and Jennings 1987). Cypress pine can be mixed with ironbarks and spotted gums on less suitable sites (Hawkins 1954). On lower slopes where sandy topsoils are shallow it may be replaced by polar box. White cypress pine is distributed in drier areas of the Queensland landscape, mostly occurring within the rainfall boundary of $300-650 \mathrm{~mm}$ (Johnston and Jennings 1987) and is relatively tolerant of dry conditions (Bowman and Latz 1993) with deaths from lack of moisture considered uncommon (Queensland Department of Forestry 1984). This tolerance is likely determined by rapid early root growth relative to seedling shoot development (Hindmarsh 1990), the production of deep feeder roots along the upper margin of moisture-retaining clay subsoils (Queensland Department of Forestry 1984) and the minimising of water loss through stomatal disposition (Clayton-Greene and Ashton 1990). Yet despite these morphological adaptations, the species' drought hardiness is by no means absolute.

\section{Impact of severe drought}

The severe and prolonged Great Drought of 1898-1902 significantly affected cypress pine across large areas of Queensland. This had a considerable impact on the density, and possibly spatial distribution, of cypress pine, particularly at its drier western extent.

In the Mitchell district great numbers of indigenous trees such as cypress pine, beefwood, gidya, ironwood, myall etc... succumbed to the effects of the drought; from the large size and apparent age of the trees, beefwood and cypress pine especially, it is surmised that this drought was more severe and protracted than any in the last fifty years.

J.V.S. Desgrand, Land Commissioner (1903)

In reference to the Cunnamulla district: ' $\ldots$... in parts of the western country it is reported in places quite $80 \%$ of the cypress pine was killed by the late disastrous drought' (Board 1904); '...the enormous numbers of [cypress] trees... which have been killed by the late disastrous drought in the western districts is a matter for very serious consideration' (Evans 1903). A letter 
from R.C. Lethbridge, the manager of Forest Vale Station, on 17th January 1903, to The Western Star, a Roma based newspaper, captured the devastation succinctly:

I suppose this has been the driest and most disastrous year ever known in the Maranoa district... Forest trees have died in thousands, and even birds have perished in large numbers.

The renowned war historian C.E.W. Bean, in his book On the Wool Track (1916) noted the impact of the drought in western New South Wales: '...a hundred square miles of pine trees, all as straight and shiny and dead as door nails' (p.30).

The losses of the native timber during the Great Drought in western Queensland indicated by these reports were considerable and the species is likely to have disappeared from several areas of western Queensland as a consequence. Extensive dead topping of remnant stems across remaining parts of this region is still considered to have resulted from this drought (Dale 1979). Apart from tree death the ecological consequences of a widespread reduction of mature seed trees due to moisture stress were likely to be lower levels of regeneration and a loss of subsequent cohorts over several growing seasons. Cypress pine did not appear to have been more sensitive to the drier conditions than Eucalyptus species although soil type is likely to have been a determinant. Pure stands of cypress occur on deep sands which, unlike shallower duplex soils, do not retain water for lengthy terms. During the extended dry period when water resources were severely limited, it is probable that stands occurring on sandy soils suffered higher losses than stands growing on moisture-retaining duplex soils. A number of large cypress pines near Charleville that are probably survivors of the Great Drought have been observed 'hugging creek beds' suggesting their survival may have been linked to close proximity to moisture availability (Michael Ince, Queensland Department of Primary Industries, pers. comm.). This follows the observation that 'cypress pine stands capable of resisting a drought of 1898-1902 proportions are rare and would only occur on excellent cypress sites' (Robinson 1961). No subsequent drought has had such a significant and widespread impact on cypress pine.

\section{Effect of above-average rainfall}

In contrast to the above there is also evidence that cypress is adversely affected by periods of above-average rainfall, especially when this follows an extended dry period. In the early 1970s a crown dieback condition began 
affecting cypress pine at Western Creek and Dunmore State Forests, which lie roughly between Dalby and Millmerran in southern Queensland. In some cases the dieback caused only parts of the tree crowns to die whilst in others it was so severe that the trees finally died. Unlike the drought, the dieback affected older cypress pine but not younger individuals nor other neighbouring forest trees such as Eucalyptus and Casuarina. By November 1974 , some 16000 hectares had been affected by crown dieback.

Dry conditions had been experienced for several years prior to the onset of the dieback condition. In the years 1964 to 1969 rainfall in the summer growing period ranged between $260 \mathrm{~mm}$ and $360 \mathrm{~mm}$, well below the longterm average for that area of $470 \mathrm{~mm}$. In the 1969/70 season summer rainfall increased to $476 \mathrm{~mm}$ and the drought was well and truly broken in $1970 / 71$ when summer rainfall reached $731 \mathrm{~mm}$, almost double that of the previous six years. Dieback was most frequent in stands in lower topographical positions where the sandy A horizon of the duplex soils was shallow and appeared to be caused by waterlogging (Lamb and Walsh 1982). In this case it seemed that the sudden change in rainfall of the magnitude recorded at Western Creek and Dunmore State Forests was sufficient to cause a significant change in the soil environment. Well aerated soils were probably saturated and waterlogged for some time and soils with impeded drainage were probably waterlogged for some months. Glasshouse trials showed cypress pine was less tolerant of waterlogging than the eucalypts of the region (Lamb and Walsh 1982).

Dieback such as this may be a determining factor in the maintenance of E. populnea (poplar box) in the low-lying flats of areas otherwise dominated by cypress pine. It is likely that these flats are colonised by cypress pine in drier years but become waterlogged following high rainfall periods causing the 'retreat' of larger pines. Juvenile pines, being shallower rooted (Forestry Commission of NSW 1988) may be able to survive in these areas for several wet years before giving way to poplar box dominance. This sensitivity, whilst linked to tree age and soil type, may contribute to the natural boundary of cypress pine in this region. Undocumented reports of dieback in the 1950s (Lamb, unpubl.) along with the occurrence of several periods over the last 100 years of above-average rainfall following several dry seasons suggest mortality due to dieback may even be more frequent than death caused by moisture stress. Given this, dieback may have a more profound influence upon the shape and structure of cypress forests in this area than drought whose impact appears to be neither as recurrent nor as species specific. 


\section{Impact of rabbits}

Three dramatic anthropogenic disturbances have also shaped the distribution of today's pine stands although each has had differing impacts on the species. The earliest of these was rabbits which were introduced to Queensland by the Queensland Acclimatisation Society on Woody Island in 1864 in addition to a spreading distribution from the southern States. Rabbits probably reached the cypress region of Queensland in 1890. Rabbits are not normally common in cypress pine forests because there isn't enough nutritious food, preferring instead to graze more open, grassy areas (David Berman, Senior Zoologist, Department of Natural Resources Queensland, pers. comm.). The deep sandy soils that support pure stands of cypress pine often do not give rise to vegetation containing the minimum 0.22 per cent phosphorous required by rabbits for normal growth, bone development and breeding efficiency (Lang 1981). However, deep sandy soils adjacent to soils with high clay content may provide a very suitable habitat for rabbits (Parer 1987) owing to higher proportions of palatable herbaceous material (Lange and Graham 1983). On more fertile soils rabbits have been shown to directly limit regeneration through grazing and indirectly through increased insolation of seedlings via removal of beneficial shading grasses (Johnston 1969). This mortality generally occurs in two distinct phases. The first phase involves direct attack by rabbits on seedlings in which a large proportion of seedlings are targeted along with surrounding ground cover. It is not clear why all seedlings are not grazed in this first phase, although greater seedling age (over 4 months) (Johnston 1969) and selective grazing owing to optimal nutrient requirements (Lange and Graham 1983) may be responsible. After this heavy, initial mortality, the lack of ground cover brought about by rabbit grazing causes increased insolation resulting in the loss of most remaining cypress regeneration (Johnston 1969).

The impact of rabbit grazing on cypress pine can be partly attributed to high stocking pressure as forests on fertile soils that were highly regarded for cattle were subject to heavier and more continuous rabbit attack (Forestry Commission of NSW 1988). Problems are most evident during droughts, when other food sources are scarce, and at high rabbit densities. In these instances of exceeded carrying capacity the rabbits are likely even to move into pure stands to seek out any moisture-containing foods (Brian Cooke, CSIRO Rabbit Control Expert, pers. comm.).

The overall result of the arrival of rabbits was a complete cessation of cypress regeneration in some localities for as long as 60 years. Landholders reported the first substantial new regeneration of cypress pine in south-east 
Queensland in the 1950s following the introduction of myxomatosis (Kirby Doak, Land Protection Officer, Department of Natural Resources, pers. comm.; Hindmarsh 1990).

\section{Introduction of prickly pear}

Another severe anthropogenic disturbance was the introduction of prickly pear (Opuntia sp.) which was first introduced to a property in Scone, NSW in 1839 to act as hedging around sheepfolds (Cameron 1999). From here it is reported that the pear was taken to Yandilla Station on the southern Darling Downs in 1843 where other settlers, impressed with its potential as stock fodder in drought times, transported the pear in saddle bags to a number of surrounding stations. It rapidly colonised the surrounding countryside at a rate of 400000 ha per year (Hando 1997; Mann 1978). Prickly pear spread throughout much of the area occupied by cypress pine including relatively undisturbed forests.

Droughts and fires have thinned these forests, and prickly-pear infests them to more or less a degree... They occurred formerly in fairly large quantities in the dry south-western districts where, however, the effects of cutting, fire, grazing, drought and prickly-pear have rendered them comparatively scarce...

Swain, Director of Forests 1920

Between the 1890 s and 1930 s attempts to eradicate prickly pear by clearing and burning decimated millions of acres of timbered land, a process that has helped shape the present pattern of forest distribution (Cameron 1999). Indeed the severity of the infestation was the primary reason why some forests (e.g. Western Creek) were gazetted as State Forest in the 1930s rather than being cleared for agriculture (Terry Johnston, pers. comm.). In 1926 the Queensland government initiated a scheme for the destruction of both the crow and emu within the pear belt on the premise that both birds were 'amongst the chief agencies by which pear seed is spread' (Payne et al., Prickly Pear Land Commission 1926). Crows were regarded as having small value as they assisted in the disposal of rotting carcasses, whilst emus were viewed as having 'practically no value' and the 'reasons for retaining it in the pear belt are none'. This scheme received widespread support from landholders and was kept in practice until the implementation of biological control of prickly pear (Table 1). The impact of removing the birds from the region, whilst probably having no direct effect on the wind dispersed cypress pine, was likely to have significantly reduced the spread of certain understorey plants resulting in lowered forest biodiversity. 
Table 1. Number of birds destroyed and bonuses paid during the period from 1 February to 30 June 1926

\begin{tabular}{lrrrr}
\hline Species & Number & \multicolumn{3}{c}{ Bonuses Paid } \\
& & $£$ & s. & d. \\
\hline Emus & 8441 & 1055 & 2 & 6 \\
Emu eggs & 7117 & 355 & 17 & 0 \\
Crows & 10039 & 250 & 19 & 6 \\
Scrub Magpies & 1154 & 19 & 4 & 8 \\
\hline Total & 26751 & 1681 & 3 & 8 \\
\hline
\end{tabular}

Source: Adapted from Payne et al. 1926

The introduction of prickly pear caused severe changes to agricultural productivity but remarkably little is known about its effects on natural forests in the areas into which it spread. Despite an absence of direct evidence, prickly pear must have hindered understorey development, including cypress regeneration during the 90 -year period prickly pear dominated these landscapes. There may also have been some longer term consequences. There is some belief that, in addition to fire protection and treatment, the removal of prickly pear following the introduction of the cactoblastis moth promoted regeneration of cypress pine and the progress of small seedlings into higher size classes (Robinson 1951).

\section{Wildfire}

The final major anthropogenic disturbance was the changes to the preEuropean fire regimes. Cypress pine is known to be extremely sensitive to fire, with reports of almost total elimination of populations following intense wildfires (Wilson and Mulham 1979; Bowman and Latz 1993). When cypress pine occurs as scattered regeneration surrounded by grass cover even quite mild fires may result in its death (Lacey 1973). Being more sensitive to fire than the hardwoods with which it occurs cypress pine is excluded from hardwood stands that are regularly burnt (Boland 1992). Injury resulting from moderate burns can disrupt seed production in mature survivors for five or more years (Hawkins 1966).

Evidence, in the form of fire scarred trunks, suggests that the majority of cypress forests incurred regular burning prior to being reserved as State Forests (Johnston 1980). The occurrence of regular fires in cypress forests apparently resulted in an open forest structure with eucalypt dominants and scattered small clumps of large cypress pine (Johnston 1980). Once 
reservation took place, early management practices involving rigid fire protection policies were applied in order to protect the valuable Callitris resource (Johnston and Jennings 1987). The absence of regular burning encouraged the development of dense undergrowth and a thickening regeneration density (Cameron 1999) and led to the gradual invasion of Eucalyptus forests by cypress pine (Hawkins 1954). Cypress pine communities aggressively expanded from a density of perhaps 100 trees per ha $(10 \mathrm{~m}$ apart) to 1000-2000 trees per ha (0.5-1 m apart) (Cameron 1999). Subsequent poorly monitored silvicultural operations placed large quantities of flammable fuel on the forest floor and, along with excessive litter-fuel buildup due to fire suppression, resulted in a number of major forest fires in the cypress pine areas of Queensland in 1951 and 1957 (Taylor 1994; Johnston and Jennings 1987). These fires led to an awareness of the danger of fuel build-up and were a deciding factor in the implementation of prescribed burning which was widely adopted in Queensland in 1966 (Taylor 1994). Depending on environmental and climatic conditions, prescribed burning now takes place every 6-10 years (Department of Natural Resources, 2000) in defined buffer zones of poorer quality cypress stands surrounding merchantable, higher quality stands (Johnston 1980). This is done in order to reduce the risk of wildfires affecting productive sections of the forest. Whilst these regular, controlled fires are likely to restrict successful widespread regeneration in the buffer zones, complete removal of regeneration is unlikely given the mosaic pattern of the burns. Sparser cypress pine communities are likely to occur in these regularly burnt margins and may herald a movement back to similar pre-European disturbance conditions. A drawback to regular burns in State Forests previously protected from fire is the higher densities of Acacia populations that can occupy large areas of forest, out-competing other understorey species and tree seedlings (personal observation). However an Acacia expansion may only exist temporarily given that regular frequent burning could lead to eventual species reduction and open forest being reinstated (Lunt 1998). Each of the four major fire types (indigenous burning, fire exclusion, wildfire and prescribed burning) has had different impacts on the ecology of white cypress pine forests. They have each yielded quite contrasting patterns of regeneration resulting in an almost mosaic stand structure in current cypress pine forests across southern Queensland. 


\section{Conclusion}

In summary, the cypress pine forests of southern Queensland have been subjected to several severe natural disturbances and several 'new' humaninduced disturbances in the last one hundred years. It appears that climatic disturbances may have affected distribution patterns, whilst anthropogenic impacts have influenced shorter-term regeneration patterns. The coincidence of natural and anthropogenic disturbances appear to generate the largest effects, e.g. the incidence of drought and high rabbit stocking which may be responsible for total exclusion of cypress pine from certain areas and long-term degradation of the original communities. Each of the humaninduced changes has persisted over at least several decades but the extent to which these have affected regeneration of cypress and other species in these forests has probably varied with the intensity and extent of the disturbance. It is apparent that the core cypress pine forests have persisted despite the changes to their shape and structure by these disturbances. However, the comparative isolation of most of these forests incorporated with the problem of research interests being focused more upon northern rainforests and plantations in preference to southern Queensland native forests has meant that few of these historical events have been very well studied. Little remains known about the impact of these disturbances on other biodiversity components such as understorey plant species and associated wildlife and may offer future avenues for research.

\section{References}

Bean, C.E.W. 1916. On the wool track. London: London: Hodder and Stoughton.

Board, G.L. 1904. Report of the Inspector of Forests., Brisbane: Department of Public Lands.

Boland, D.J. 1992. Forest trees of Australia. Melboume: CSIRO Publications, Melboume.

Bowman, D.M.J.S. and Latz, P.K. 1993. Ecology of Callitris glaucophylla (Cupressaceae) on the MacDonnell Ranges, Central Australia. Australian Joumal of Botany, 41: 217-25.

Cameron, D. 1999. Battling the Brigalow: A contextual thematic overview bistory of the forested areas of the southern brigalow belt bioregion, 1827-1999. Brisbane: Queensland Government.

Clayton-Greene, KA. and Ashton, D.H. 1990. The dynamics of Callitris columellaris/Eucalytpus albens communities along the Snowy River and its tributaries in south-eastem Australia. Australian Joumal of Botany, 35: 403-32.

Dale, J.A. 1979. Growth and yield of white gppress pine in the Injune-Augathella zone of south-west Queensland. Department of Forestry Queensland (: Technical Paper, 13).

Department of Natural Resources 2000. A guide to fire management in Queensland. Brisbane: the Department. 
Desgrand, J.V.S. 1903. Extracts from the report of Mr. J.V.S. Desgrand, Land Commissioner for the Aramac, Blackall, Isisford and Tambo Districts. Brisbane: Department of Public Lands, Brisbane.

Evans, J.B.O. 1903. Extract from The report of Mr. J.B.O. Evans, Land Commissioner for Roma, Surat, Taroom, Charleville and Cunnamulla Districts. Brisbane:, Department of Public Lands.

Forestry Commission of NSW 1988. Notes on the Silviculture of Major N.S.W. Forest Types. 10. Cypress Pine Types. Sydney:, Department of Forestry NSW, Sydney.

Hando, R. 1997. Prickly Pear. In: R. Hando and V. Hando (Eds), Going Bush with Chinchilla Nats. Chinchilla Field Naturalist's Club Inc., Chinchilla, pp. 52.

Hawkins, P.J. 1954. Regeneration problems of narrow leaf ronbark (E. crebra) and cypress pine (C. glauca) in south west Queensland. Honours thesis, University of Queensland, Brisbane.

Hawkins, P.J. 1966. Seed production and litter fall studies of Callitris columellaris. Australian Forest Research, 2(2): 3-16.

Hindmarsh, J.A. 1990. How green is ny tree? A report on the problem of white gpress pine (Callitris columellaris) regeneration in the Bingara district., Soil Conservation Service of New South Wales.

Johnston, T.N. 1969. The effect of sheep and rabbit grazing on regeneration of white cypress pine. Australian Forest Research, 4(2): 3-12.

Johnston, T.N. 1980. Prescribed burning-its role in spress pine forests, Fire Conference Proceedings. Queensland Govt., Gympie, Qld, pp. 1-6.

Johnston, T.N. and Jennings, KS. 1987. Management of cypress pine forests in Queensland, Forest Management in Australia: Institute of Foresters of Australia. Biennial Conference. Surrey Beatty, Perth.

Lacey, C.J., 19 1973. Silvicultural characteristics of white gpress pine. Forestry Commission of New South Wales (Research Note 26).

Lamb, D. and Walsh, K. 1982. The effect of salinity and water-logging on a gpress pine community. Report to Australian Water Research Foundation (Report, No. 79/403).

Lang, J. 1981. The nutrition of the commercial rabbit. Part 1. Physiology, digestability and nutrient requirements. Nutrition Abstracts and Reviews Series B, 51: 197-225.

Lange, R.T. and Graham, C.R. 1983. Rabbits and the failure of regeneration in Australian arid Acacia. Australian Journal of Ecology, 8: 377-81.

Lunt, I.D. 1998. Allocasuarina (Casuarinaceae) invasion of an unbumt coastal woodland at Ocean Grove, Victoria: Structural changes 1971-1996. Australian Journal of Botany, 46(56): 649-56.

Mann, J. 1978. The pPear mMenace. In: C. Black, E. Stewart, S.A. Blanchard and G.A.R. Barron (Eds), Chinchilla Centenary 1878-1978 Souvenir Booklet. Chinchilla: Chinchilla Centenary Celebrations Committee and Chinchilla Historical Society, Chinchilla.

Parer, I. 1987. Factors influencing the distribution and abundance of rabbits (Oryctolagus cuniculus) in Queensland. Proceedings of the Royal Society of Queensland, 98: 73-82.

Payne, W.L., Power, F.D. and Purcell, W. 1926. Second annual report of the Prickly Pear Land Commission being for the year ended 30th June 1926. Brisbane:, Department of Public Lands.

Queensland Department of Forestry 1984. Forest management in Queensland. Brisbane: Queensland Govemment., Brisbane.

Robinson, W. M. 1961. Extracts from annual reports-Department of Public Lands reflecting effects of $1900 / 02$ drought on timber stands. Dalby: Department of Forestry. 
Robinson, W.M. 1951. Extracts from the Prickly Pear Land Commission-effects of pest on State Forests. Dalby:, Department of Forestry

Swain, E.H.F. 1920. Annual Report of the Director of Forests for the year ended 30th June 1920. Brisbane: Department of Public Lands.

Taylor, P. 1994. Grouing up: forestry in Queensland. St. Leonard's, N.S.W: Allen and Unwin..

The Western Star, Roma, 17th January, 1903.

Wilson, A.D. and Mulham, W.E. 1979. A survey of the regeneration of some problem shrubs and trees after wildfire in western New South Wales. Australian Rangeland Joumal, 1: 363-9. 


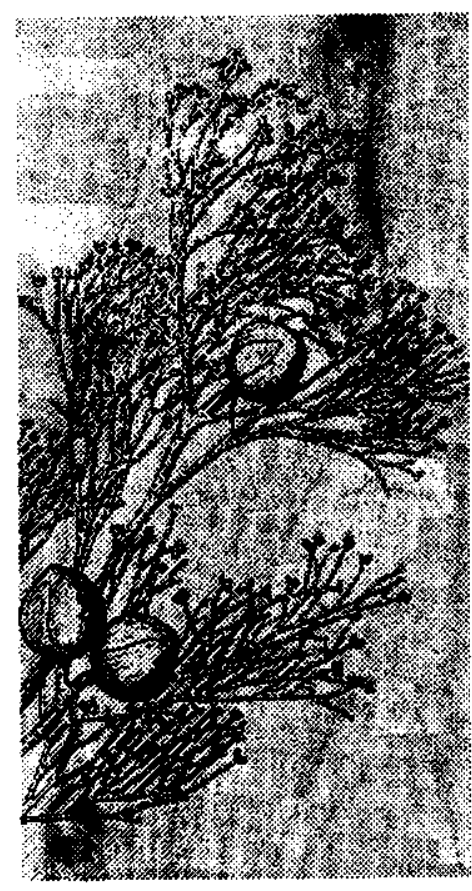

\title{
17
}

\section{Management plans for cypress forests}

\author{
John Dargavel \\ and Margaret Kowald
}

\section{The controlled forest}

Forestry is a deliberate, purposeful affair, modern and scientific in its principles, whose prime concern with producing wood has changed to a much wider concern today. It has a tradition of formal long-term planning to achieve a sustained yield and to serve the extension, internal communication and legitimisation needs of state agencies (e.g. Schlich 1889, D'Arcy 1891, Recknagel 1913). Plans-termed 'management plans' or 'working plans'are generally made for 5,10 or 20 -year periods. They provide both central control of, and continuing guidance for, changing forestry staff in dispersed locations. Once officially authorised at a high level, they legitimise what the foresters do and help ward off local pressures. However, they can easily be irrelevant if not properly prepared, or when there are catastrophic events, or when markets or social expectations change, or they may be simply ignored by the foresters or by-passed in the political process. What is planned is not always what eventuates.

This paper considers how the needs of the state were realised by planning and control of state forests and crown timber reserves in the white cypress regions of Queensland and New South Wales in four phases from the 1910s to the present. The first phase of mapping, assessment and timber planning lasted until the 1950s. The next phase saw the regeneration of the forest and 
more knowledgeable timber planning. A phase of multiple-use planning started in the 1980s and is extending currently into a comprehensive phase.

\section{New South Wales and Queensland}

Australian forestry is largely an affair of state agencies. Although both New South Wales and Queensland inherited the same tradition of planning, shared the general history and ethos of Australian forestry (Carron 1985, Dargavel 1995), and signed the National Forest Poligy Statement in 1992, they took different paths to planning similar forests. This has to be seen in the context of differences in their economic and political development and in their geography. Queensland developed much later than did New South Wales. By the 1910s Queensland had only about one-third of the population of New South Wales and it was Sydney's burgeoning timber market, rather than Brisbane's small demand, which was prized most. New South Wales' cypress region had the advantage of being linked to Sydney by rail, whereas most of Queensland's was linked only to the Darling Downs and Brisbane markets. In New South Wales, a government forestry department was already established. It had a field staff of ninety and was managing about two million hectares of forest reserves. Forestry was only just starting in Queensland and although about a quarter of a million hectares of forest had been reserved, it had a field staff of only nine (Hutchins 1916).

Table 1. Proportion of dominant cypress forest by tenure (including species other than Callitris glaucophylla)

\begin{tabular}{lcccc}
\hline State forests & $\begin{array}{c}\text { Nature } \\
\text { conservation } \\
\text { reserves } \\
(\%)\end{array}$ & $\begin{array}{c}\text { Leasehold } \\
\text { and other } \\
\text { Crown lands } \\
(\%)\end{array}$ & $\begin{array}{c}\text { Private } \\
\text { freehold }\end{array}$ & $(\%)$ \\
\hline New South Wales & 60 & 9 & 6 & 25 \\
Queensland & 24 & 1 & 24 & 51 \\
\hline
\end{tabular}

Source: Binnington 1997

Although both States gradually increased the areas of state forest and developed well-staffed forest services, the relative difference persisted. In Queensland, the largest areas of cypress pine forests are held in leasehold and private tenure; in New South Wales they are in State forests (Table 1). 


\section{First phase: making the forest legible}

\section{New South Wales}

We take up our story in 1911 when at the age of 28, Edward Harold Fulcher Swain (1883-1970) was appointed District Forester for the North-West District of New South Wales, based at Narrabri. His career marks the start of modern, or what he termed 'systematic forestry' in both States (Frawley 1999; Meyer 1985). He went on to become head of the nascent Queensland forest service in 1918 and, after a short period working as a consultant, returned to New South Wales in 1935 to head its service as Commissioner for Forests.

The cypress forests Swain was to manage had been delineated from pastoral runs in a piecemeal fashion from the $1880 \mathrm{~s}$. Each had been given a name and-much like soldiers-a number. Except for the 'million wild acres' of the Pilliga, they were scattered in discontinuous blocks across a wide landscape. Many had been and some still were leased to graziers under the Crown Lands Acts provided that they thinned out the forest to let the remaining trees grow better. As a 1902 report was to remark, 'the lessee's interest, a grazing one, does not always coincide with the preservation of timber growth' (NSWF 1902). It was not only the timber cutters that Swain had to control.

Regulations for controlling the timber industry specified a minimum girth limit, below which trees should not be cut, required workers and sawmills to be licensed, and required royalties to be paid on the quantity of timber cut from public land. The Narrabri District was important because it generated almost a quarter of the Department's revenue. The staff spent most of their time obtaining compliance and collecting revenue, but had hardly started systematic forestry. Swain tackled the problems with characteristic vigour. The forests had to be mapped and organised into manageable units, or 'compartments', their resources estimated, roads and tracks constructed for access, accommodation for guards built in the forests and fences erected to control stock. A three-stage pattern of planning was devised which proceeded forest by forest.

Assessment was the first stage. Swain not only commenced systematic strip assessments of his district, but wrote a manual to be applied across the whole State (Swain 1914). In the case of East Cookeys Plains State Forest, for example, the assessment was done by Mr Temporary Surveyor and Assessor, K. Walker, who, in April 1918, submitted his report to the District Forester at Forbes (FFO 1918, 1919). It described the forest and reported the number of trees and their volume by diameter size classes. The next 
stage was to prepare an 'Organization Report' which reiterated the assessment and added details. Walker recommended that East Cookeys Plains should be divided into 10 compartments and that certain infrastructure should be provided. With the District Forester's annotation, it was sent to Sydney where the 'Forest Working Plan' was prepared and formally approved by the Commissioners in June 1919.

The Working Plan is a short, three-page document which follows the classic two-part structure. The first descriptive part records that the forest was originally declared as a timber reserve in 1884 'to protect a valuable belt of pine timber on Burrawang holding', but excisions 'in the interests of settlement' in 1898 and 1913 reduced it by 30 per cent to 3246 hectares. The document notes location, distance to markets, rainfall, climate and soil, and a heading of 'Organization' sets out the amounts needed for an overseer's house $\left(£^{500}\right)$, a fire lookout $\left(£^{10}\right)$, fencing $\left(£^{345}\right)$ and firebreaks $\left(£^{73}\right)$. White cypress pine is reported to be the only commercial species and a summary table of the assessment records the number of trees by three size classes for each compartment. The second prescriptive part, headed Working Plan', declares the object of management to be the 'production of cypress pine mill timber and poles' and specifies the subdivision of the forest into 10 compartments. The 'prescription' follows. It notes that there are three times as many trees in the 7-9 inch $(18-23 \mathrm{~cm})$ class as in the $10 \mathrm{inch}$ and over $(25+\mathrm{cm})$ class. Allowances were made for thinning and loss, a diameter growth rate of 1 inch $(2.5 \mathrm{~cm})$ in $7 \frac{1}{2}$ years was assumed and an annual permissible cut set at 2500 trees a year for the following 8 years. Finally, fire protection was specified.

Once approved, log sales from each compartment were monitored against the plan on control sheets kept in Head Office with all the usual difficulties and errors of such systems. Adjustments had to be made from time to time and approval sought. For example, seven approvals were given in the period 1921 to 1925 for departures from the Working Plan for Back Yamma State Forest (FFO 1928).

Planning proceeded quite rapidly in New South Wales so that plans for over 350000 hectares had been approved by 1921, with larger areas still in the assessment and organization stages (NSWFC 1921). But while planning proceeded, rabbits advanced through the forests, destroying the regeneration that appeared after good seasons (NSWFC 1918, 1919). And it became apparent that the early assumptions about growth rates were overly optimistic. In 1914 it had been thought that cypress pine could have an average diameter growth of $1.1 \mathrm{~cm}$ a year, so that it would take only 28 years to produce a $30 \mathrm{~cm}$ diameter mature tree, but in 1918 the working plan for 
Back Yamma forest assumed a diameter growth rate of only $0.25 \mathrm{~cm}$ a year, so that it would take 20 years for the $20-23 \mathrm{~cm}$ class trees to become $25 \mathrm{~cm}$ mature trees.

The 1920s and 1930s must have been a dismal time for the foresters. With no regeneration, the forest had no sustainable future, and with such slow growth, even the immediate future of the mills was doubtful. A special review of cypress resources of the Central Division was ordered. Except for parts of the Pilliga, most of the individual state forests were found to be incapable of supporting a small local mill with 10000 logs a year for a decade. Rather than plan each small forest separately, it was deemed advisable to group numbers of State Forests in reasonable proximity to one another into units of management, each capable of maintaining small mills for a limited number of years' (NSWFC 1928). The forests which could not be grouped were to produce power poles, effectively 'high-grading' them by 'thinning from above' to remove the biggest and best logs.

Determining the rate of growth is central to the calculation of the sustainable yield of any forest. Although increment plots were installed and measured in the Pilliga State Forests for many years, it seems that few were installed elsewhere and the records appear to have been lost (Chapter 18, this volume).

\section{Queensland}

Queensland's forests were less known than those in New South Wales. Swain recruited returning soldiers and pushed general surveys to find forest areas of vacant Crown land that might be saved from agriculture. Once these were found, more detailed feature and assessment surveys were carried out, either to support a claim for their reservation as state forest, or to estimate their timber value for selection (Dargavel and Moloney 1997). For example, 180000 hectares of forests at Chinchilla were assessed in 1920, of which 142000 were thought suitable for permanent reservation (QDF 1920). Once state forests were declared, they were assessed and organization reports prepared, as in New South Wales.

Working plans were certainly envisaged and some prepared. Swain realised that the small forest and timber reservations should be grouped into 'Working Plan Areas' for the purpose (QPFB 1926a, 1926b). In the Dalby Working Plan Area, for example, 20900 hectares had been assessed by 1926 and 105 compartments laid out-or 'run'-and marked. By 1933, Swain could report that 'though progress on working plan work has been good a large amount of this work remains to be done, while the revision of plans at present in operation is also calling for attention' (QPFB 1933). Work was 
concentrated on the important hoop and bunya pine forests of the coast and no working plans for the cypress region were completed as cypress was of only local economic importance in the 1930s and less than half the production came from state forests and timber reserves. It was realised that 'there was a long way to go before the [cypress pine] areas are completely brought under management' and their yield increased on a sustained basis (QPFB 1935).

Swain's major task was to have more forests declared as state forests. However, as timber production came as much from the leasehold and freehold lands as it did from state forests, state planning may have been irrelevant and certainly there was little point in planning fellings during the Depression when little of the produce could be sold. Swain did, however, exercise firm control of his small, widely spread staff by starting a system of circulars in 1924 which set out the procedures to be followed in a great many activities.

\section{Second phase:}

\section{regeneration, expansion and development}

Cypress forestry took a new lease of life in both States when, in 1952, after seventy years without effective regeneration in most areas, myxomatosis decimated the rabbits and there were good seasons with widespread regeneration. Moreover, the thriving economy of the 1950s and 1960s enabled the timber industry and the forest services to expand and develop better techniques. Aerial photography made the forests legible as never before, statistical techniques eventually transformed assessment methods, and computer processing and modelling standardised their analysis.

\section{New South Wales}

A second round of planning commenced through the whole cypress pine region in the late 1940s and 1950s. It had the two stages of assessment and working plans, but omitted the previous organization stage, which had largely been completed. The forests were mapped from aerial photographs according to a statewide system of forest types and strip surveys were continued to assess the timber resources.

The consequent working plans were more elaborate documents, typically of 10-25 pages to which several tables of assessment and other data were appended. Although some of the forests were grouped, the areas they covered were still remarkably small and served very small sawmills. For 
example, the Peak Hill group of six state forests only amounted to 3940 hectares with a permissible cut set in 1953 of 3300 cubic metres of logs a year (FFO 1953). The larger Forbes group of 15 forests, which included the important Back Yamma amounted to 15580 hectares but yielded only 6000 cubic metres of logs a year, distributed between three sawmills in Forbes, Parkes and Eugowra.

Comparisons between the first and second assessments enabled changes to the diameter distribution to be seen over a considerable period-30 years in the case of East Cookeys Plains State Forest where growth was calculated at 1.7 cubic metres per hectare per year. A few increment plots were established to gain a better idea of growth; for example, three established in East Cookeys Plains in 1953 were measured annually for a decade.

District foresters were made responsible for monitoring performance against these plans by having to submit a short annual management report comparing actual quantities cut against the permissible yields which had been set.

The assessment and planning system was completely changed in the 1970 s and a third round of planning was commenced. Strip surveys were abandoned, partly because people could no longer be found or afforded to do it, and replaced with a statistically-designed 'continuous forest inventory' system, based on plots. The lengthy typed assessment reports were replaced by computer-based systems to record both the areas of forest types and stands, and the periodic measurements of the continuous inventory plots. Computer models were developed to project changes in the diameter distribution of the forests and hence calculate the permissible cut. Moreover, the forests were grouped again into larger units for management planning purposes.

The transition to the new system was confusing and time-demanding. For example, the plan for the Forbes Management Area was scheduled to be done by District staff in 1983, but all sorts of difficulties arose so that it was only at the end of 1986 that it was finally submitted for approval.

\section{Queensland}

Queensland took a similar path in developing its assessment procedures, taking advantage of the Forestry Research Centre at Dalby, aerial photography and a continuous forest inventory system based on permanent, remeasured plots which were established from the 1940s (Dargavel and Moloney 1997). Survey crews—or 'camps' - operated in the Dalby District with the majority of their work being directed to cypress areas. Their periodic forest inventory surveys provided both maps and the calculations of possible 
future yields. From the late 1950s, a great deal of the assessment effort had to be directed to leasehold lands where lessees were applying for freehold title under the Nicklin Government's 1957 Lands Act. Some areas of cypress, especially between Injune and Augathella were surveyed from the air with subsequent checking of volumes on the ground.

Rather than make formal long-term plans, Queensland continued its close, centralised control. The assessment reports with estimates of possible yields were sent to the Resources Branch and then to the Department's Harvesting and Marketing Branch in Brisbane. The Department negotiated the allocations to the licensed sawmills from approximately 1979 with arrangements legitimised by ministerial approval. Prior to the allocation system, sales were by auction or auction purchased priority. However, cypress pine management across the region was inconsistent. Clough (1969) reviewed its history in the Inglewood area of the Warwick District and found that it had been 'inadequate and haphazard'. He thought that this was due to 'lack of trained staff, shortage of funds and inadequate inventory data'. The situation was probably more general.

\section{Third phase: uses beyond wood and cattle}

The turmoil of environmental conflicts which erupted in Australian forests during the 1970s and 1980s forced the States to alter their land allocation policies and allow some public participation in allocation and management decisions (Dargavel 1995, Hutton and Connors 1999). More national parks were reserved from Crown lands and some transferred from state forests. The forest services, excoriated by the environmental movement and facing a crisis of legitimisation, declared 'multiple-use' policies to recognise that timber production was not necessarily their prime object in every patch, and they developed 'codes of forest practice' to minimise the environmental damage of logging and building roads. Importantly, they undertook far more comprehensive and publicly available planning. The environmental conflicts focussed on pine plantations, rainforests and coastal forests rather than the dry forests and woodlands west of the Divide. Although statewide policies applied to the cypress forests, there was little pressure to change their management.

\section{New South Wales}

New South Wales Forestry Commission changed its policies (NSWFC 1976) and its planning and mapping system when it adopted its Preferred 
Management Priority Classification' scheme (NSWFC 1982). This delineated each patch of the forest according to its main or mix of uses, showing, for example, buffer strips along streams, wildlife corridors or steep slopes which were not to be logged. Once prepared, the maps were opened for public inspection and comment. They were primarily directed to operational planning at the compartment level and were accompanied a few years later by a 'Forest Practices Code' (SFNSW 1993 with subsequent revisions).

Plots were re-measured, yields recalculated and forest management plans revised for groups of forests. The coastal forests were the first priority, but by 1988 plans had also been prepared or revised for the Western Division enabling the Commission to declare that its planning covered the whole State.

\section{Queensland}

In 1976, Queensland's Forestry Act 1959 was amended to recognize the multiple uses of forests and incorporated, with timber, the values of grazing, soil conservation, water quality and recreation. The state declared its policies in 1984 (QDptF 1984) and set out a formal planning structure which would provide 'the public with factual information about the Department's management objectives and procedures' in the belief that 'having [plans] available must improve the Department's image' ( $Q D p t F$ 1985). A scheme to zone the forests according to the multiple uses and values was devised, Management Priority Area Zoning (MPAZ) (Prineas 1987), and the planning process was started. It called for a draft plan to be prepared, made available for public comment in light of which a final plan would be prepared, approved and issued. It was a manual, paper based system which partitioned forestry land into primary priority use zones with a variety of secondary uses. However, its implementation was hampered by a lack of information, staff and resources to undertake the planning (Kehl et al. 2000). Furthermore, the Department was embroiled in major disputes over the Wet Tropics, Fraser Island and the Conondales (Holzworth 1999) and planning proceeded slowly, especially in the non-contentious cypress region.

Plans were drafted for seven forests in the cypress region, but only in the case of Taroom State Forest Group was the plan opened for public comment-by two conservation organisations and three Government agencies-and eventually issued in 1992. The drafts for the Passchendaele and Dalby areas were drafted in 1989, edited in 1991, but not carried through the public comment and issue stages. A draft prepared in 1989-90 for the Chinchilla area was still a draft five years later. However, these plans, 50-60 pages long, were of limited value to practical forest management. They 
mostly contained descriptive material, lists of animals, birds and plants, and statements of Departmental policies and practices. The annual timber allocations to sawmills were stated and it was noted that these were derived from yield predictions made by 'computer models' which would ensure 'that the productive potential of the forests will be sustained' (QFS 1992). A large plan of some 280 pages for the extensive Roma Forestry District was probably started in the late 1980 s, but like the other uncompleted plans, was left as a draft as the whole direction of Australian forest planning was overtaken by a larger vision of a sustainable future.

\section{Fourth phase: conceiving a sustainable future}

The concepts of ecological sustainability and sustainable development gained international prominence in 1992 at the United Nations Commission on Environment and Development's (UNCED) conference in Rio de Janeiro. Such concepts and the continued political controversies at home, induced Australian Governments to sign the National Forest Poligy Statement (1992). At roughly the same time, a broad-ranging restructuring of Australian public services was occurring and the States realised that their forest services' crisis of legitimacy had to be overcome. The forest services of both States were renamed and their responsibilities for timber production, environmental protection, policy, planning and control reassigned between departments.

The national forest policy called for the establishment of a 'comprehensive, adequate and representative' system of conservation reserves, developing sustainable forest management practices, undertaking 'comprehensive regional assessments' and negotiating regional forest agreements between the Commonwealth and State Governments (Dargavel 1998). It was a major shift from the concept of multiple use to the concept of preserving biodiversity. It recognised the diversity of the uses and values of the forests more seriously and it required a complete revision of the planning systems. Geographic Information Systems were deployed to make a wider range of forest attributes legible.

The new planning systems were applied to the major regions with commercial forests and Commonwealth involvement. Even though the Commonwealth was politically disinterested in the cypress forests, both States extended the systems to them. However, as the assessments are still in progress for the cypress regions and the stage of formal planning has yet to come, we can only make brief comments about them. 


\section{New South Wales}

A new system of conservation reserves was specified for each biogeographic region. Its aim was to preserve 15 percent of the area of each vegetation type that was thought to have existed at the time of the European occupation. While the new planning processes were proceeding in the contentious coastal forests, some preparation work was started in the cypress region. It was particularly important because most of the surviving - albeit substantially modified-forest vegetation in the Western Region of New South Wales is located on public land (Table 1). There was a clear recognition of other values and uses with commencement in the 1990s of new improved yield plots (1996), fauna and flora surveys (mid-1990s) and an improved inventory system (1998). Furthermore, studies of three cypress forests (and one red gum forest) were undertaken to look at questions about the extent, distribution and structure of the original forest and how it had been changed (Allen 1998, Curby 1997, Lennon 1997, van Kempen 1997). Notably, they took a landscape and cultural history approach, rather than research an ecological history from biological sources. A comprehensive regional assessment is now in progress (Chapter 20, this volume).

\section{Queensland}

There were influences in the 1990 s that hampered the progress of management planning in Queensland. In addition to proposed legislative changes that did not eventuate and the Regional Forest Agreement process in South East Queensland, there were major administrative changes that resulted in the commercial (wood production) and non commercial arms of forestry being separated into Department of Primary Industries and Department of Natural Resources respectively. Forest management planning did not receive priority attention as staff focused on the adaptation to different management and departmental structures and policies. Responsibility for management planning was now with Department of Natural Resources and draft management plans languished between staff now in separate agencies.

In 1998, development began on an enhanced management planning process that integrated expert assessments of forest values with community values. Whereas previous management planning was a desktop exercise by forestry experts in each district, the new process incorporated GIS and decision support technology with the capacity for structured community participation (Tumaneng-Diete and Waring 2000).

As to the cypress areas, apart from fire management and logging plans, sub-regional management planning has been slow. Some preparatory studies 
have been undertaken in cultural heritage (Cameron 1999) and forest condition and ecosystem health (Eyre et al. 2000) but no formal plans have commenced. The focus has been on other parts of Queensland especially the coastal mountain forests and North Queensland.

\section{Acknowledgments}

We have been most generously provided with help and advice by Rod Clark, Andrew Deane, Don Nicholson and Patrick Tap in New South Wales; and by John Alcock, Trevor Beetson, Chris Bragg, Simon Cottier, Peter Holzworth, Peter Kanowski Snr, Peter Male, Jim Nicol, Dick Pegg, Brian Roberts and Brian Schaumberg, in Queensland.

\section{Sources}

Queensland, Department of Natural Resources, Brisbane Office. Draft management plans. Queensland, Department of Primary Industry-Forests:

Brisbane Office, Forestry Circulars.

Dalby Office, Draft management plans.

State Forests of New South Wales:

Dubbo Regional Office, Extracts from historical records files.

Forbes Office, Management files for individual forests.

\section{References}

FFO $=$ New South Wales, Forbes Forest Office

NSWF $=$ New South Wales, Forestry Branch

NSWFC $=$ Forestry Commission of New South Wales

$\mathrm{QDF}=$ Queensland, Director of Forests

$\mathrm{QDptF}=$ Queensland,Department of Forestry

$\mathrm{QFS}=$ Queensland Forest Service

$\mathrm{QPFB}=$ Queensland, Provisional Forestry Board

SFNSW $=$ State Forests of New South Wales

Allen, M.R. 1998. Case studies of three gppress pine forsts in the Lachlan and Bogan River catchments, Forbes Forestry District on Back Yamma, Euglo South and Straborm State Forests. Pennant Hills, NSW: State Forests of NSW.

Australia 1992. National forest policy statement: a new focus for Australia's forests.

Binnington, K. 1997. Austratian Forest Profiles: White Cypress Pine, 6. National Forestry Inventory. 
Cameron, D. 1999. Battling the Brigalow: a contextual thematic overvien bistory of the forested areas of the Southern Brigalow Belt Bioregion, 1827-1999, Environmental Protection Agency, Brisbane.

Carron, L.T. 1985. A bistory of forestry in Australia, Australian National University Press. Clough, N. 1969. A review of white cypress management in the Inglewood Sub-District. Mss, Department of Primary Industry-Forestry Library, Brisbane.

Curby, P. 1997. Namandera study on Buckinbong, Gillambab and Matong State Forests. Pennant Hills, NSW: State Forests of NSW.

D'Arcy, W.E. 1891. Preparation of forest working plans in India. Calcutta: Supt. of Govt. Printing. Dargavel, J. 1995. Fasbioning Austratia's forests, Melbourne: Oxford University Press.

Dargavel, J. 1998. Politics, policy and process in the forests. Austratian Journal of Environmental Management 5(1): 25-30.

Dargavel, J. and Moloney, D. 1997. Assessing Queensland's forests. In John Dargavel (ed) Australia's ever-changing forests III: Proceedings of the Third National Conference on Austratia's Forest History. Centre for Resource and Environmental Studies, The Australian National University, pp.61-73.

Eyre, T., Kelly, A. and Jermyn, D. 2000. Cypress forest condition in the Southem Brigalow Bioregion, Queensland, unpublished report.

FFO 1918, 1919. File B1829: Assessment Report, 18 April 1918; Organization Report, 24 December 1918; Forest Working Plan, 24 June 1919.

FFO 1953. File 243. Secretary, NSW Forestry Commission to District Forester, Dubbo 10 March 1953.

FFO 1928. File B1824. Secretary, NSW Forestry Commission to District Forester, Forbes, 13 August 1928.

Frawley, K 1999. Establishing professional forestry in Queensland: the Swain years, 19181932. In John Dargavel and Brenda Libbis (eds) Australia's ever-changing forests $I V$ : Proceedings of the Fourth National Conference on Australia's Forest History. Centre for Resource and Environmental Studies, The Australian National University, pp.144-64.

Holzworth, P. 1999. Recent forest use disputes in Queensland: a history of resolution. In John Dargavel and Brenda Libbis (eds) Austratia's ever-changing forests $V$ : Proceedings of the Founth National Conference on Australia's Fonest History. Centre for Resource and Environmental Studies, The Australian National University, pp.205-23.

Hutchins, D.E. 1916. A discussion of Australian forestry. Perth: Govt. Printer.

Hutton, D. and Connors, L. 1999. A history of the Australian envinonment movement. Cambridge University Press.

Kehl, J., Waring, B., Smith, R and Nalder, D. 2000. Multiple use management planning in Queensland, Australia: the Koombooloomba Ecotourism Project as a case study. Unpubl. conference paper.

Lennon, J. 1997. Studies for the Westem Forest Region of New South Wales. In John Dargavel (ed) Austratia's ever-changing forests III: Proceedings of the Third National Conference on Austratia's Forest History. Centre for Resource and Environmental Studies, The Australian National University, pp.347-52.

Meyer, A. 1985. The foresters. Institute of Foresters of Australia.

NSWF 1902. Annual Report.

NSWFC 1918, 1919, 1921, 1928. Annual Repont.

NSWFC 1976. Indigenous Forest Poligy. 
NSWFC 1982. Preferred Management Priority System.

Prineas, T. 1987. Management priority area zoning. Brisbane: Queensland Department of Forestry (mimeo.).

QDF 1920. Annual Report.

QDptF 1984. Forest management in Queensland. Pt. I General forest polices and management strategies: development to current status, Pt II Detailed forest management functions and aims (objectives, policies and strategies).

QDptF 1985. Guidelines of the preparation of sub-district management plans and state forest group management plans. Circular 2164, 2 Jan 1985.

QFS 1992. Taroom State Forests Group Management Plan.

QPFB 1926a, 1933, 1935. Annual Report.

QPFB 1926b. Circular 170, 23 June 1926.

Recknagel, A.B. 1913. The theory and practice of working plans. New York: John Wiley (2nd edn. 1917). Facsimile of $1^{\text {st }}$ edn. at URL: http://moa/cit.comell.edu.neh

Schlich, W. 1889-1925. Schlich's Manual of Forestry, v. III, Forest management (2nd edn 1892, 3 edn 1925). London: Bradbury Agnew.

SFNSW 1993-1999. Forest Practices Code: timber barvesting in native forests.

Swain. E.H.F. 1914. Practical forest assessment and survey. Sydney: Department of Forestry (Bulletin No. 9).

Tumaneng-Diete, T. and Waring, B. 2000. Sustainable Forest Management Context: the case of the Gold Coast Hinterland State forests. Paper presented to International Ecological Economics Society Conference, Canberra, 5-8 May 2000.

van Kempen, E. 1997. A history of the Pilliga oppress pine forests. Pennant Hills, NSW: State Forests of NSW. 


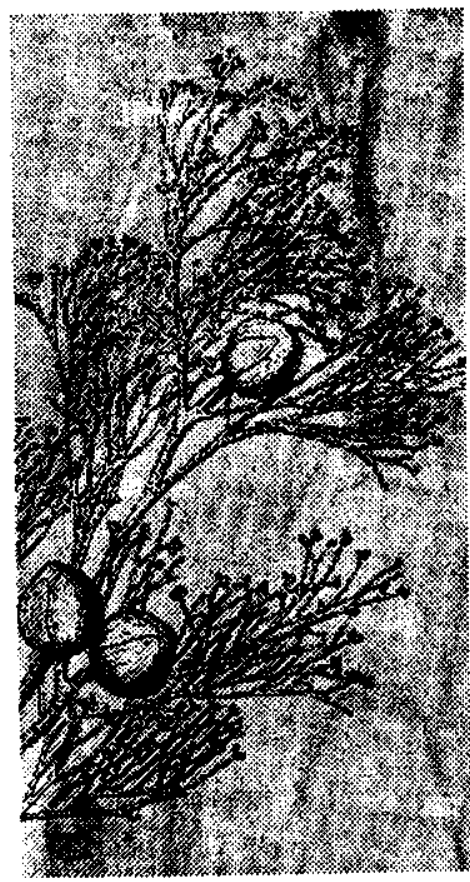

18

\section{Calculating}

sustained yields in

New South Wales

cypress forests,

1915-1957

\section{Andrew Deane}

\section{Introduction}

Early sustained yield management in white cypress forests influenced current forest condition through guiding the type, pattern and intensity of logging, as well as influencing the sawmilling industry that developed around the cypress resource. The numerous definitions of sustained yield have common themes of forest protection and regeneration, and harvesting being regulated in accord with the productive capacity of the forest. For example, the Society of American Foresters (1958) defined sustained yield management as: 'Management of a forest property for continuous production with the aim of achieving at the earliest practicable time, an approximate balance between net growth and harvest, either by annual or somewhat longer periods'.

Most definitions concem continuity of yield rather than continuity of growth, as a forest may be growing continuously but not yielding continuously, because in initial stages the forest is composed of trees that are too small for harvest. Further, sustained yield is difficult to achieve in any forest resource that is unbalanced in either age or size classes. Both size and age imbalances are encountered in New South Wales cypress forests because white cypress regenerates in even-aged cohorts at infrequent intervals, and takes several decades to reach a commercial size.

The idea of sustained yield is attractive because it implies maintaining forest productivity, and distinguishes the forestry profession against simple 
liquidation. Yet its apparently simple basis and 'intuitive appeal' belie its complexity and difficulty of implementation. The concept of sustained timber yield has been a fundamental tenet of responsible forest management since the eighteenth century. In recent decades, it has been subsumed within a larger definition advocating the sustainability of all forest values. However, this work focuses on timber production.

\section{Finite resource and the need for regulation}

The suitability of white cypress forests for agriculture and their widespread destruction is widely documented, yet despite the reservation of many white cypress stands in protective tenures, their preservation was not assured as logging was poorly regulated prior to 1916 (Allen 1998). The circumstances of early forest management and yield regulation in New South Wales were summarized as follows by the 1908 Royal Commission of Inquiry on Forestry (page ix):

From its inception the laws relating to forestry, and under which it has been administered, were those designed for the occupation and settlement of the public estate, and embodied no aim for the maintenance of forests in perpetuity or for their treatment on scientific or systematic lines, nor did they include any policy of conservation or reproduction. The working code or regulations issued under these laws were largely ineffective, and differed little in detail until the year 1902 , when the first systematic steps in the direction of protecting immature forest growths and in systematically checking the exploits of forest products were taken.

Jolly (1918) deplored the unproductive condition of Australian forests following unregulated logging, and emphasized the need to regulate timber yields on the basis of the productive capacity and condition of forests, and not on the cutting capacity of sawmills. Jolly believed that despite the obvious wisdom of sustained yield, too often the concept had been ignored or abused in Australia.

Early foresters working in white cypress in New South Wales recognized that it was a finite resource (with the added complication of rabbits preventing regeneration), and that it would be necessary to carefully regulate logging in order to maintain the productive capacity of the forests and to ensure the continued availability of cypress timber. 


\section{Early assessments and working plans, 1915-1934}

A lack of basic resource information to enable management planning prompted assessment surveys of the State's cypress forests. The survey methodologies were similar for all cypress forests (e.g. Swain 1915) and were adopted from techniques used in the northern hemisphere (Frayer and Furnival 1999). They were primarily timber inventories to determine the volume of merchantable timber, along with assessing sub-merchantable size classes and the projected volumes that would become available when these reached merchantable sizes.

Sawmilling technology at that time restricted utilisation to those trees that were 10 inches $(25 \mathrm{~cm})$ diameter at breast height $(\mathrm{dbh})$ or greater, and sustained yields were calculated based on removing 10 inch trees at a rate equaled by the recruitment of 9 inch trees into the 10 inch size class. Information on growth rates was required to calculate the time necessary for the transition of sub-merchantable trees into the merchantable sizes, and two different methods were used for determining cypress growth rates in the north and south of the State. Determining growth rates for white cypress is problematic, and it is interesting to see how early foresters addressed the problem.

\section{Northern approach: determining growth percentage}

Instructions by Swain (1915) stipulated the use of Schneider's formula for calculating volume increments and sustained yields for areas from Coonabarabran to Inverell, including the Pilliga forests. Schneider's formula is a growth percentage formula that was commonly used in the Northern Hemisphere until the mid-twentieth century, and provided a convenient means of calculating volume increment. It was probably adopted to obtain information about cypress diameter and volume increments quickly, in contrast to the delayed results from growth plots.

\section{Using Schneider's formula}

Schneider's formula converts diameter growth information into a ratio of volume increment by relating initial tree size to subsequent increment added onto the wood capital. It assumes that tree growth approximates compound 
interest, and thus the resulting growth percentage is a fixed ratio and not a volume (Chapman and Meyer 1949).

The information on diameter growth was obtained by using an increment borer to sample trees at breast height $(1.3 \mathrm{~m})$. From the core sample the number of growth rings for the outermost inch of radius under-bark were counted and termed 'Rings Per Inch' for use in the formula, which usually takes the following form:

$$
\text { where: } \begin{aligned}
\mathrm{p} & =400 /(\mathrm{rd}) \\
\mathrm{p} & =\text { volume increment percent, } \\
\mathrm{r} & =\text { number of growth rings in the outermost inch of radius, } \\
\mathrm{d} & =\text { diameter at breast height over-bark in inches, and } \\
400 & \text { is a factor relating log length and taper. }
\end{aligned}
$$

For example, a single tree 12 inches $(30 \mathrm{~cm}) \mathrm{dbh}$ and showing ten rings in the last inch of radius under-bark, and with low height would have a growth percent of:

$$
\mathrm{p}=400 /(12 \times 10)=3.33 \%
$$

The sustained yield could then be calculated on the basis of an assumed average volume for each tree over 10 inches $\mathrm{dbh}$ and given in the form of the number of trees that could be cut from an area annually. Although the example above follows Swain's (1915) instructions, in practice sustained yields were mostly calculated using the time taken for 9 inch trees to grow into the 10 inch merchantable class, in a similar manner to the southern cypress areas discussed later.

Schneider's formula attempts to account for varying site quality by changing the constant relating to log length, e.g. 400 (poor), 450 (average) and 500 (good). Swain's instructions were to use these constants although he did not define the categories, leaving them to individual interpretation. The relevance of these constants for Australian conditions must be suspect as Turnbull (1958) found that the log length factor varied greatly from these three figures.

\section{Utility of Schneider's formula}

Its main advantages of speed and simplicity result from using assumptions and generalizations, thus avoiding intensive fieldwork and delays in obtaining results. The accuracy of approaches that count growth rings rely on correct ring identification (Biondi 1999), however this is known to be difficult for white cypress (Dunwiddie and La Marche 1980).

Schneider's formula wrongly assumes that future growth will equal past growth, although growth rates actually decline throughout the life of a stand. 
Therefore Schneider's formula is liable to over-estimate future volumes, and using the same growth percentage for subsequent periods compounds the error (Chapman and Meyer 1949).

The formula uses a constant log length and taper, incorrectly assuming that mature trees have no increase in log length, and that volume increment derives solely from diameter growth. Turnbull (1958 and references therein) concluded that the log length constants in Schneider's formula can vary greatly within and between species, and that Schneider's formula is too inaccurate and unreliable for practical use. No record of a decision to cease using Schneider's formula with cypress is known, although Lindsay (1945) states that increment borers had been found to be impractical for sampling cypress.

\section{Actual growth rates in the North}

Where cypress increment cores were used with Schneider's formula the derived volume growth percentage was generally between 2 and 3 percent. However, contrary to Swain's instructions increment cores were not sampled from the majority of the northern cypress forests, and instead an optimistic assumed growth rate of 1 inch dbh every six years $(4.2 \mathrm{~mm} /$ annum) was used in most yield calculations. Possibly there were insufficient increment borers available at the time of the surveys, thus making estimates necessary, but the above growth rate would be mostly unachievable given varying site quality and the conservative silviculture of the time.

The most optimistic growth rate found recorded comes from Tailby State Forest, where in 1921 an increment of 0.43 inch $(11 \mathrm{~mm}) \mathrm{dbh} /$ annum was assumed. The magnitude of the error was highlighted following the establishment of an increment plot on this forest in 1929. After twenty years, the average total dbh increment was 1.41 inches $(35.8 \mathrm{~mm})$. The fastest growing tree exhibited 15 rings per inch, while the slowest gave 59 rings per inch. After forty-four years of measurements the average annual diameter increment was 0.073 inch $(1.9 \mathrm{~mm})$.

\section{Southern approach: diameter increment plots}

Periodic measurement of permanent plots is an effective method of obtaining growth information about trees provided it can be related to the broader forest resource, although interpolation is required to obtain information on 
annual growth (Biondi 1999). This approach was implemented in cypress areas from Dubbo to Narrandera.

Until early 1918, Working Plans gave growth rates for the Dubbo and Forbes forests as: 'average annual diameter increase Dubbo 0.215 " [5.5 mm] and Forbes 0.404 " [10.2 mm]'. These growth rates were given to three decimal places which indicates they were derived from data, although no source was given. Increment plots around Dubbo were located on Beni and Dubbo State Forests, probably on Yarinjury State Forest, and possibly Cowl State Forest (Duncan Mackay and Mark Allen pers. comm.). Three old growth plots known in forests around Forbes (viz. Tomanbil, Mulyandry and Wilbertroy State Forests) probably provided the high growth rate used in the Working Plans for Forbes. In 1949 the Forestry Commission of New South Wales was unable to provide information on the Forbes plots, and any records are probably lost.

While the Dubbo rate is optimistic, the Forbes rate is a gross error that was revised down in late 1918 to 1 inch $\mathrm{dbh}$ in $71 / 2$ years $(3.4 \mathrm{~mm} /$ annum). This revised Forbes figure was also used in Working Plans for the forests of Condobolin and Narrandera. Although these assumed growth rates would lead to unrealistic sustained yields, such volumes were frequently reduced by 10 or 20 percent to allow for uncertainty, and for the most part such yields were not fully utilized by the time new surveys were carried out in the 1940s. Lindsay $(1947$, 1957) later demonstrated that the diameter increment for southern areas was generally about 1 inch $\mathrm{dbh}$ in 15 years $(1.7 \mathrm{~mm} /$ annum).

Working Plans for southern cypress forests used growth rate information to determine the time required for the transition of the sub-merchantable 9 inch size class into the merchantable 10 inch class. This time period was used as the basis for harvesting all of the existing 10 inch class, however as each size class became merchantable the number of millable trees would vary, and thus sustained yield would need to be varied periodically.

\section{Lindsay's surveys and the Inch Class Method, 1940-1957}

Cypress forests were again assessed during the 1940s and early 1950s. Sustained yields were no longer calculated for individual forests, but rather, proximate forests were combined into 'management groups', with Doug Lindsay completing Management Plans for these by 1957. These management plans used conservative tree growth rates (generally 1 inch dbh in 15 years), and calculated sustained yields using the 'Inch Class Method'. This 
method not only calculated yields from the ingrowth of sub-merchantable stems into merchantable sizes (in the manner of the early Working Plans), but also estimated the volume increment of the various merchantable sizes to give a more realistic estimate of total merchantable volume increment.

Sawmill utilization standards had improved so that 8 inch $(20 \mathrm{~cm}) \mathrm{dbh}$ became the minimum size for a merchantable tree. Lindsay (1945) used the following formula to calculate total annual volume increment assuming in this example that 60 percent of the total volume increment derives from the recruitment of 7 inch trees into the merchantable 8 inch dbh class:

$$
\mathrm{AI}=(2 \mathrm{nv} / \mathrm{r}) \times(100 / 60)
$$

where: $\mathrm{AI}=$ total annual volume increment per acre,

$\mathrm{n}=$ number of trees per acre in the 7 inch dbh class,

$r=$ average rings per inch of the 7 inch trees ( 30 rings per inch or 1 inch dbh in 30 years in this instance), and

$\mathrm{v}=$ the assumed volume of an 8 inch tree (40 super feet or $0.13 \mathrm{~m}^{3}$ ).

The Inch Class Method risks overestimating total volume increment where stands are not fully stocked, because it assumes increment on all areas regardless of whether they are adequately stocked or not. Initially this error was countered by deducting 20 percent from the estimated gross volume increment to allow for 'mortality and contingencies'. Later estimates calculated increment only for adequately stocked areas and assumed no growth on poorly stocked areas, also giving a conservative result. The Inch Class Method also risks over-estimating sustained yields if there is a preponderance of 7 inch trees with few other trees in the smaller sizes, however a 20 percent reduction of the calculated yield was used for areas where this was thought to apply.

In drafting Management Plans for the Forbes and Grenfell areas Lindsay (1957) stated that due to the laborious nature of the calculations required for the Inch Class Method, he had instead decided to use a growth percentage of 3 percent. This was easy to apply and gave a more realistic estimate by attributing growth to all size classes, although he noted that 3 percent 'may be slightly optimistic'.

Strip surveys were discontinued in cypress in 1954, with the management plans compiled by Doug Lindsay generally prescribing yields until the early 1960 s, but the prescribed sustained yields were extended until new assessments were carried out in the late 1960s. These later assessments switched from simplistic strip surveys to the more sophisticated sampling designs and statistical analyses then becoming available (Frayer and Furnival 1999). 


\section{Conclusions}

The surviving yield calculations and records for southern areas are generally well-preserved, comprehensive, and resemble timber inventory techniques used today. However, no records were found of actual yield calculations for northern cypress forests. The methods are described and the results are noted, but records of actual calculations appear not to have been kept.

The early sustained yield calculations for New South Wales cypress forests were simplistic but appropriate to the resource and growth information available at that time. The implementation of early Working Plans meant that working towards sustained yield over large areas probably began sooner in western New South Wales (for both white cypress and also river red gum forests) than elsewhere in the State. Sustained timber production from NSW cypress forests was largely achieved because the sustained yields were conservative (frequently being revised downwards by 20 percent to allow for uncertainty) and were frequently under-utilized until World War II.

The sustained yields that were determined for white cypress forests from the early twentieth century influenced the forests that we see today by quantifying and limiting the volumes that could be sustainably removed. In achieving sustainability of timber supply, the timber values of these forests were maintained, and the State government was able to resist calls for their revocation to become farmland, leaving a valuable legacy of vegetation remnants in an agricultural landscape.

\section{Acknowledgments}

Helpful comments on an earlier draft were kindly provided by John Dargavel and Diane Hart. Background information was kindly provided by Frank Barrett, Ian Frakes, Jim Stevenson, Duncan Mackay and Mark Allen.

\section{References}

Allen, M.R. 1998. Forest bistory projects for State Forests of New South Wales. Case studies of three gppress pine forests in the Lachlan and Bogan River catcbments, Forbes Forestry District on Back Yamma, Euglo South and Strahom State Forests. Sydney: State Forests of NSW.

Biondi, F. 1999. Comparing tree-ring chronologies and repeated timber inventories as forest monitoring tools. Ecological Applications. 9(1): 216-27.

Chapman, H.H. and Meyer, W.H. 1949. Forest Mensuration. New York: McGraw-Hill.

Dunwiddie, P.W. and La Marche, V.C. 1980. Dendrochronological characteristics of some native Australian trees. Austration Forestry. 43: 124-35. 
Frayer, W.E. and Fumival, G.M. 1999. Forest survey sampling designs: a history. Joumal of Forestry. 97(12): 4-10.

Jolly, N.W. 1918. On an elementary principle of forestry. The Australian Forestry Joumal 1(4): 6 .

Lindsay, A.D. 1945. Pilliga National Forest. Plan towards the stabilization of the native timber industry on a sustained yield basis. Unpubl. report. Forestry Commission of NSW.

Lindsay, A.D. 1947. Narrandera cypress pine survey. Unpubl. report. Forestry Commission of NSW.

Lindsay, A.D. 1957. Forbes cypress pine survey. Unpubl. report. Forestry Commission of NSW.

Society of American Foresters. 1958. Fonest Terminology. 3rd edn. Washington D.C., Society of American Foresters.

Swain, E.H.F. 1915. Forest Assessment and Working Plans. Unpubl. report. Forestry Commission of NSW.

Tumbull, KJ. 1958. Stem analysis techniques and applications, and some studies of secondgrowth Douglas fir in Western Washington. M. For. Thesis. University of Washington. 


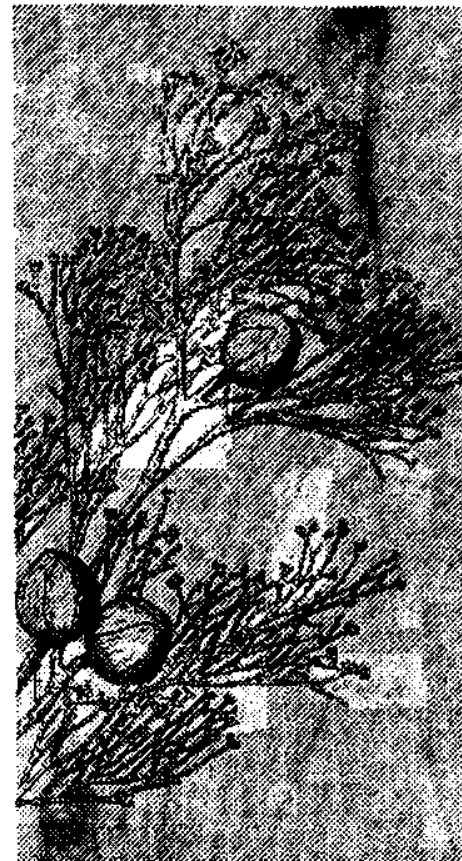

\section{9}

\section{A vanishing presence: Queensland forest heritage}

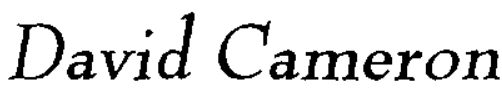

Almost three million hectares of public forests, principally state forests and national parks, are located in the Southern Brigalow Belt Biogeographic Region (Southern Brigalow), including more than half of Queensland's State forest estate (Department of Natural Resources 1999; Environmental Protection Agency 2000a). Within these forests lie the remnants of millennia of Aboriginal existence and 160 years of non-Indigenous human activity layered upon, and amalgamated with, the Indigenous fabric. The remnant historic cultural heritage fabric provides evidence of the tragic process of invasion, occupation and dispossession experienced by the Indigenous people and, conversely, echoes of the experiences of the non-Indigenous people who sought to fashion a new world for themselves. The Southern Brigalow's public forest estate is a significant repository of this remnant fabric: a fabric both fragile and deteriorating-a vanishing presence. The long-term sustainable management of historic cultural heritage values across the public forest estate is a significant challenge for forest managers.

Extensive stands of white cypress pine (Callitris glaucopbylla) exist right across the Southern Brigalow belt and it is a common species in an expansive line of forests stretching along the western side of the Great Dividing Range from Texas-Goondiwindi in the south, and north and west through Inglewood, Millmerran, Cecil Plains, Chinchilla, Condamine, Yuleba, Surat, Roma, Injune and Tambo. 
Evidence of colonial occupation and development abounds across the cypress forests of the Southern Brigalow. The forests of the Southern Brigalow were first occupied and exploited by colonial settlers on the eastern Darling Downs from around 1840. Pastoralists moved into the region from the New England district to the south and later from the Moreton and Brisbane Valley districts to the east. Livestock grazing, at first principally sheep and later cattle, provided the initial economic stimulus for the exploration and occupation of the Southern Brigalow.

Indeed, pastoral pursuits, and to a lesser degree agriculture and timber getting, made colonial occupation of the Southern Brigalow a viable proposition and have been the foundations of the region's economy from the 1840 s until the present day. During the late 1840s explorers such as Ludwig Leichhardt (1844-45 and 1846-47), Thomas Mitchell (1846) and J.C. Burnett (1847) traversed sections of the Southern Brigalow. Their reports inspired pastoralists hungry for more grass, to follow the snaking lines of the explorer's tracks. Following in their wake the pastoral frontier then moved west and north-west from the Darling Downs, reaching the Maranoa and Leichhardt districts by the 1850 s, followed by the Burnett, Dawson, Bauhinia, Springsure and Tambo districts by the $1860 \mathrm{~s}$.

Despite the political-economic ascendency of pastoralism in Queensland, the promotion of closer settlement agriculture was a consistent preoccupation of most Queensland governments from the late 1860 s onwards. Agricultural settlement began to occur within the Southern Brigalow during the 1860 s and 1870 s, firstly on the eastern Darling Downs and then in the expansive cypress forests near Millmerran, Cecil Plains, Goondiwindi and further north in the Rolleston and Springsure districts during the 1880s. Later closer settlement spread out along either side of the western railway in the Dalby, Chinchilla and Roma districts during the 1890 s, followed by the Burnett, Dawson and Callide River Valley districts during the 1920s and, more recently, the Brigalow Scheme blocks in the Taroom and Arcadia Valley districts during the 1960s (Cameron 1999).

In many regions across Queensland, mining has often been in the van of development and in providing the opportunity for the 'opening up' of many isolated forest landscapes. Within the cypress belt, mining has played only a relatively minor role in the development of those forests. Apart from several small gold fields such as those in the Canal Creek (Gore), and Thanes Creek (Pratten and Leyburn) districts, several coal mines, and some oil and gas production, mining has generally been limited to small-scale and isolated metals mining operations. Coal mining, however, is set to have a huge impact on some of the cypress forests on the Darling Downs where they grow above the rich seams of the Surat-Dawson Basin coal measures. 
Together with grazing, dairying and crop growing, the timber industry has also made a significant contribution to the successful occupation of the region. The exploitation of timber and the manufacture of timber products in the Southern Brigalow were closely linked to the development of the pastoral and agricultural economy. The evidence of timber getting and sawmilling activity is quite common across the region's cypress forests. At times large communities lived and worked in these forests. Ironbark and spotted gum were the principal commercial species cut in the Southern Brigalow well into the twentieth century. The termite resistant white cypress pine (Callitris glaucophylla) was not considered a commercially viable timber until the $1880 \mathrm{~s}$. The availability of native softwoods and hardwoods in the region's forests greatly assisted the movement of settlers across the region.

The first forestry reserves established in the Southern Brigalow were among the first established in Queensland and these early reserves today form the core of the state's largest state forest at Barakula near Chinchilla. During the construction of the Western railway between Dalby and Roma a timber reserve was established at the Baking Board (a few kilometres west of Chinchilla) by the Railways Department in 1876. The Baking Board reserve was extended and two new reserves, the largest timber reserves in the colony, were established in the area, the Wallan/Dogwood Creek timber reserve (50182 hectares) and the Chinchilla/Colamba timber reserve (46 621 hectares) (QVP 2 1885; QVP 3 1889). Today these reserves exist within the boundary of the present Barakula State Forest No. 302 (250 000 hectares).

The economic value of the western hardwood and cypress forests for timber production was first recognised by the Queensland government during the 1870 s and 1880 s, but it was not until the early 1920 s that the state began to invest heavily in forestry works in the region (Taylor 1994). In the Southern Brigalow during the 1920s large areas of Crown land and existing reserves were surveyed, forest stations, nurseries and work gang camps were established, silvicultural treatment conducted, and forestry related infrastructure developed. By the 1930s the Forestry Department considered white cypress pine to be a species of sufficient economic significance to warrant expanding the area of white cypress forest held under reserve and to begin intensive forest treatment work to enhance the productivity of the western white cypress forests.

In 1941 the first continuous forest inventory system plots were established in Queensland at Western Creek State Forest. This system, adopted from North America, was initiated to monitor forest growth in order to more accurately calculate sustainable yields (Dargavel and Moloney 1997). During World War II the Forestry Department established camps in the 
many forests in the Southern Brigalow to hold Italian, Albanian, German and other 'alien' internees who undertook silvicultural treatment work and constructed firelines and roads. After World War II white cypress pine increased in importance as a commercial timber species and production increased dramatically. During the 1950s and 1960s cypress and hardwood demand increased and the timber industry and forestry presence in the western cypress forests reached its peak. However, from the early 1970s Forestry's investment in native forest treatment and infrastructure began to decline. Staff and infrastructure have been systematically removed from the forests and many once busy forest stations and camps are now deserted. Today the human presence in these forests is diminishing along with the material physical reminders of the past (Cameron 1999).

It is only of relatively recent times that the value of non-Indigenous or historic cultural heritage associated with colonial occupation and later rural development located on the public forest estate has been recognised. Like most areas of Queensland, historic cultural heritage has not been systematically conserved nor managed on Queensland's public forest estate. That which survives has for the most part done so because of its continuity of use, isolation, luck or through the ad boc management practices and the enthusiasm of Department of Natural Resources, Department of Primary Industries-Forestry, and Queensland Parks and Wildlife Service personnel and other stakeholders such as grazing permit lessees. Surveys of many state forests and national parks have revealed, that while there is a great richness, diversity and broad distribution of historic cultural heritage fabric across the cypress belt, this heritage is rapidly deteriorating under the pressure of many threatening processes. Typically one might expect to find a few charred stumps to indicate where a homestead once stood, or some scattered glass, ceramic debris and old bottles at a looted bottle dump of a long abandoned road-side inn.

Through a lack of understanding, the cultural heritage values of forests are sometimes threatened by the management practices of government departments and land management agencies. Until the late 1990s both the Department of Natural Resources and the Department of Primary Industries-Forestry, (the former having primary custodial responsibility and the latter largely responsible for commercial functions), have given little consideration to the maintenance of historic cultural heritage values, particularly with respect to the demolition or removal of forestry infrastructure which may have cultural heritage significance. Similarly, in many national parks it has been common practice to 'clean up' the evidence of pastoral and other non-Indigenous activity in an effort to enhance the natural values of the landscape. As a result of these legitimate management 
activities the finite historic cultural heritage values of the public forest estate have been diminished.

Fortunately, all government agencies with responsibility for the management of public forests are beginning to develop strategies, policies and tools to better manage the cultural heritage values they are responsible for. The release of the National Forest Policy Statement, to which Commonwealth and all state governments are signatories, and the adoption of Ecologically Sustainable Forest Management in Queensland's State forest estate, have raised the level of public and government awareness of the importance of cultural heritage values inherent within our forests. Moreover, the process of Comprehensive Regional Assessments associated with the South East Queensland Regional Forest Agreement identified the richness, diversity, distribution and significance of these historic cultural heritage values and suggested possible management strategies to assist with the long-term conservation of these values and places (Powell 1998; Lennon 1998).

In Queensland the Regional Forest Agreement resource assessment process for South East Queensland included an investigation of cultural heritage resources located on the public forest estate. Approximately 950 cultural heritage places were recorded in the South East Queensland Bioregion and entered into the Cultural Heritage Information on the Environment and Forests database (Environmental Protection Agency 2000b). A similar, although less expansive and intensive survey was conducted in forested areas of the Southern Brigalow by the author and other officers from the Environmental Protection Agency. More than 800 historic cultural heritage sites were identified (Cameron, 1999). The database at present contains information on 1750 places located in the South East Queensland and Southern Brigalow bioregions.

The diversity of types of cultural heritage places recorded in the cypress forests in the Southern Brigalow includes airfields, barracks, bores, bridges, cabins and lookouts, camps, coach and wagon routes, dams, diggings, explorer routes and camps, fences, fire breaks, firing ranges, forest stations, gates, graves, homesteads, huts, military bases, mines, plane crash sites, railways, roads, roadside inns, sheds, smelters, stockyards, survey and other blazed trees, survey and work camps, telegraph lines, towers, tracks, training areas, tramways, water races, wells, woolsheds and workshops.

The historic fabric present on the public forest estate can be divided into several categories: Agriculture, Communications, Exploration and Survey, Forestry, Military, Mining, Pastoral, Railways, Recreation, Road Transport and Travel Routes, Scientific, Settlement, and Timber Production. The Environmental Protection Agency surveys, and ongoing cultural heritage values assessment and management planning conducted by the Department 
of Natural Resource's Forest Planning and Sustainable Use section, have found that much of the historic cultural heritage in the forests is fragile and deteriorating. The material substance of this fabric, predominantly timber and iron, and their location in the forest landscape, means these places are vulnerable to many natural and human threatening processes. Under present funding arrangements, neither the Department of Natural Resources nor the Queensland Parks and Wildlife Service have adequate resources to engage in anything more than very limited cultural heritage conservation works. Presently these agencies are directing their efforts towards systems that will assist with the management of threatening processes, such as the Cultural Heritage Management Information System that utilises generic place type profiles to provide basic operational management information for the protection of cultural heritage values.

Disuse, scavenging, recycling, fire, weathering, regrowth, tree clearing, rot, termites and oxidisation are among the threatening processes that without conservation management will eventually destroy almost all of the remnant fabric of colonial and twentieth century life in the forests. For the most part, the remnant fabric of the forest demonstrates, quite literally, the process of societal change. The common thread linking most historic cultural heritage places in the forest landscape is abandonment. The spectre of failure, struggle, harsh living and working conditions, economic change and isolation is apparent in the ruins that litter the western cypress forests. Sometimes the existing forest landscape is juxtaposed with the historic landscape. For example, many 'natural' clearings in western forests were once nineteenth century sheep folds. These clearings are composed of heavily compacted soil and have remained open landscapes surrounded by dense regrowth forest where once thousands of sheep grazed in open grassy woodland.

Abandoned homesteads, huts and other dwellings are common in the western cypress forests. One extant example is a well built sawn-board homestead, located near Inglewood in State Forest 341, which stands abandoned in testament to the destructive impact of prickly pear infestation that occurred early in the twentieth century. Many families who took up selections prior to the advance of the pear watched as their livelihood was slowly strangled. Others took up forest blocks on Pear Leases under which a farmer could earn title to the land in return for clearing it of the pear menace. Few were successful; many were forced to abandon their blocks never to return.

Stockyards and fencing present another type of management challenge. Yards and fences are very common, indeed ubiquitous in the forest landscape. However, some types of yards and fencing are quite old or rare and 
provide physical links with the early development of some areas. Many large sheep runs dating from the 1840 s and 1850 s were located on what is now state forest. Most of these runs were subsequently broken up into smaller grazing blocks, reserved as state forest and leased for grazing, or alienated for closer settlement. For example, some post and rail fences associated with sheep grazing exist in forests where sheep have not been grazed for a century or more. Where grazing leases are held on state forest, stockyards, fences and other infrastructure are routinely repaired and up-graded. In some cases remnant fabric of early pastoral activity can be destroyed by developments of more recent decades.

Each place is also a component of a broader cultural landscape. The scale, richness, diversity and significance of these landscapes varies considerably. One example of an extraordinary cultural landscape within the forests of the Southern Brigalow is the Barakula State Forest. Much of the significance of the Barakula cultural landscape is derived from its early pastoral history (c.1840s), the continuity of livestock grazing and timber production over the past 160 years and its long-standing protected status as timber reserve and state forest from the late 1870s onwards. This continuity of public tenure, sheep and cattle grazing, timber production, and intensive management for forestry purposes have shaped a unique native forest landscape and contribute to its historic cultural heritage significance.

Currently located within the forest are remnants of the route and camp sites of Leichhardt's 1844 expedition to Port Essington, evidence of the period of the early sheep runs (1846 to the 1880s), including sheep folds, washpools, the ruins of homesteads and coach change stations, and old dray and wagon routes. Significantly, these places provide evidence of the shared cultural heritage of Indigenous and non-Indigenous people. Artefacts such as worked iron and glass tools are illustrative of the interaction between Indigenous people and colonial settlers and their respective cultures. Of course, many Indigenous people also lived and worked on these properties. Overlaid on this fabric are newer fences, stockyards, homesteads, bores and so forth associated with the waves of closer settlement that occurred between the 1880s and 1920s. Other aspects of life in the forest survive such as remote sawmill ruins and associated camps and hamlets and an extensive range of forestry related infrastructure dating from the $1910 \mathrm{~s}$. Indeed, the structure of the forest itself is in places part of the cultural heritage fabric. The silvicultural treatment of many compartments at Barakula has been so intensive that it has generated a native forest that some older forestry hands have observed to be almost akin to a native plantation.

The management of historic cultural heritage values, particularly built heritage in isolated forest landscapes such as Queensland's cypress forests, is 
a significant challenge. In almost every case forest managers can only apply a passive management strategy, principally doing what they can to reduce threatening processes such as wildfire. Cultural heritage has to be conserved and managed within the context of the full suite of forest values and activities and land managers must assess the allocation of scarce resources in line with competing priorities. The success of such a strategy will not only require a planning regime that manages places in a broader context, but will require the commitment of local communities to develop a sense of ownership and responsibility for the conservation of their shared heritage.

\section{References}

Cameron, David. 1999. Battling the Brigalow: a contextual thematic overvies history of the forested areas of the Soutbern Brigalow belt biorgion. Brisbane: Biodiversity Planning Unit, Environmental Protection Agency.

Dargavel, John and Moloney, Damien. 1997. Assessing Queensland's forests. In John Dargavel (ed), The coming of age: forest age and beritage values. Report of the concepts of forest age seminar held at Jervis Bay as part of the 'Australia's Ever-changing Forests III Conference' 24-28 November 1996. Canberra: Environment Australia (Technical Series No 1).

Department of Natural Resources. 1999. Forest resources state forest estate registers. Brisbane.

Environmental Protection Agency. 2000a. Annual report Environmental Protection Agency 1999-2000. Brisbane.

Environmental Protection Agency. 2000b. Cultural heritage information on the environment and forests database. Brisbane.

Lennon, Jane and Associates. 1998. Protecting cultural heritage values and places in South East Queensland forests. Brisbane: Department of Environment \& Heritage.

Powell, Judith. 1998. People and trees: a thematic history of South East Queensland with particular reference to forested areas, 1823-1997. Brisbane: Department of Environment \& Heritage.

QVP-Queensland, Parliamentary Votes and Proceedings, 2 (1885); 3 (1889); 4 (1901).

Taylor, Peter. 1994. Growing up: forestry in Queensland. Brisbane: Department of Primary Industries - Forestry. 


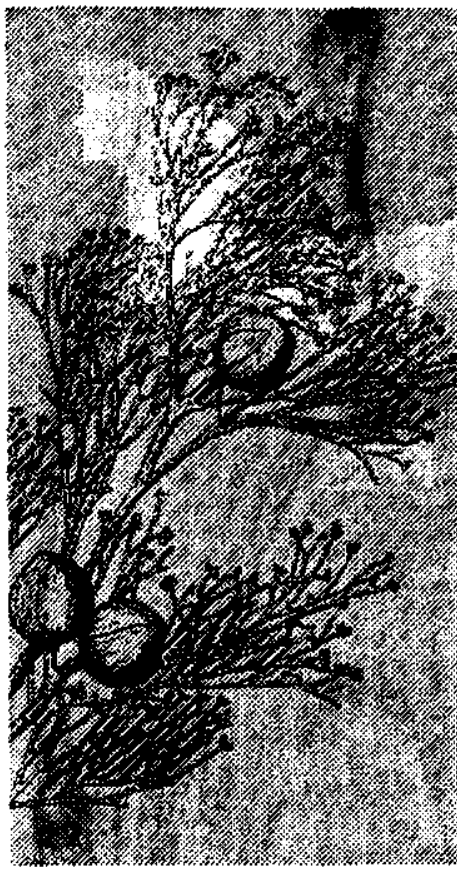

20

Disturbance history

mapping in

New South Wales

\author{
Pauline Curby, Michael \\ O'Neill, Rhondda O'Neill \\ and Patrick Tap
}

\title{
Introduction
}

In 1996, State Forests of New South Wales commissioned three studies to examine the history of the cypress pine forests of the central western wheatbelt. The objective was to list and describe the processes and events that had modified the forests and their distribution between 1750 and 1996. Selected forests in the Forbes (Allen 1998), Narrandera (Curby 1997) and Pilliga districts (van Kempen 1997) were examined. These studies provided a valuable insight into the history of the region. However, they were limited in their applicability to forest management because they were largely descriptive with limited reproduction of available spatial information.

This paper briefly describes the methods and outputs of a management history project established in late 1999. The project used a Geographic Information System to derive a set of digital layers for selected forests in the vicinity of Dubbo and the Pilliga. These layers were based on textual and spatial information obtained from forestry records and maps. The project was undertaken for the Resource and Conservation Assessment Council as part of the Regional Assessments for Western New South Wales (RACAC 2000). 


\section{Methods}

The project investigated the management history of 31 State forests and two Nature Reserves (Table 1). The time frame was 1920 to 1999. Information was obtained through discussions with staff from State Forests of New South Wales and the New South Wales National Parks and Wildlife Service, and by collating data contained in State Forests' annual reports, compartment histories, databases, files and maps that show the extent of harvesting, fire and silvicultural treatment (Table 2).

Table 1. State Forests and Nature Reserves (NR) studied

\begin{tabular}{|c|c|c|c|c|}
\hline \multicolumn{5}{|l|}{ Dubbo forests } \\
\hline Beni & Cobbora & Eura & Lincoln & Wongarbon NR \\
\hline Breelong & Coolbaggie NR & Goonoo & Mogriguy & Yarindury \\
\hline \multicolumn{5}{|l|}{ Pilliga forests } \\
\hline Baradine & Denobollie & Merriwindi & Quegobla & Yaminba \\
\hline Bibblewindi & Etoo & Minnon & Ruttley & Yarrigan \\
\hline Coomore Creek & Euligal & Orr & Timmallallie & Yearinan \\
\hline Cubbo & Jack's Creek & Pilliga East & Waubebunga & \\
\hline Cumbil & Janewindii & Pilliga West & Wittenbra & \\
\hline
\end{tabular}

Table 2. Examples of non-digital information held by State Forests of New South Wales (files unless specified*)

\begin{tabular}{ll}
\hline Annual Management Reports & Management Plans \\
Annual Reports & Management statistics* \\
Compartment history records* & Mining Leases \\
Dedications & Mining on State Forests \\
Fire reports & Mining records \\
Forest leases & Occupational Permits \\
Form 48 (yield information) & Production statistics* \\
General management records & Yield and revenue folders* \\
Harvesting, silviculture \& fire maps* & \\
\hline
\end{tabular}

Data were entered on a database developed for the collation of textual information. Separate databases were used for the Dubbo and Pilliga areas. Each database included a data entry form with drop-down text boxes tailored to the needs of the forests in question. The database fields are further described in the project report (RACAC 2000). Information on 
disturbance events was collected at whatever scale was available (i.e. specific point, sub-compartment, compartment, forest or landscape).

Where spatial information was available, the record was coded with a unique spatial identifier based on the State Forest and compartment number. Where original mapped sources were utilised, the maps were coded so that they could be related to the relevant record in the database.

\section{Results and Discussion}

Information was found for a number of categories of disturbance (Table 3). The majority of data was related to harvesting (Table 4). These records were mostly obtained from annual reports of revenue and yield. Mapping to subcompartment level (see below) was dependent on the quality of compartment histories and the level of mapping undertaken by local personnel. Information on disturbances other than harvesting was patchy and was usually only depicted on hard copy maps.

Table 3. Examples of types of disturbance for which records were found

\begin{tabular}{lll}
\hline Product removed & & \\
\hline Bridge timbers & Fencing & Piles \\
Brushwood & Fuel (wood) & Pinus \\
Charcoal & Girders & Poles \\
Christmas trees & Gravel & Posts \\
Craftwood & Hardwood & Sawlog \\
Cypress & Hardwood sawlog & Sawn/hewn (sleepers etc.) \\
Cypress sawlog & Houseblocks, blocks & Sleepers \\
Cypress posts & Junk & Vineyard posts \\
Eucalyptus oil & Mining timber & \\
\hline Other disturbance & & \\
\hline Charcoal pit & & Mining \\
Experimental growth & Non-commercial thinning & Silviculture \\
Fire - control bum & Old buildings & Stacked \\
Fire - wildfire & Previous clearing & Suckered \\
Grazing & Removal of mature trees & Top disposal \\
\hline
\end{tabular}

Notes: Quantities removed reported in feet (cubic, lineal, super), yards (cubic), gallons, litres, metres (cubic, lineal), pieces, tons or tonnes.

Size of area affected reported in acres or hectares. 
Table 4. Examples of categories of disturbance that are coded in the data base and could be used to produce Geographic Information System layers and maps

Product removed

$\begin{array}{ll}\begin{array}{l}\text { Fencing and } \\ \text { mining timber }\end{array} & \begin{array}{l}\text { Blocks, fencing, fencing timber, round stumps for house } \\ \text { blocks, mining, mining timber, posts, rails } \\ \text { Firewood }\end{array} \\ \text { Large products } & \begin{array}{l}\text { Charcoal, firewood, fuel } \\ \text { Girders and piles used for bridges, poles for bridges, buildings } \\ \text { or telephone cables }\end{array} \\ \text { Sawlogs } & \begin{array}{l}\text { Cypress logs, hardwood logs, logs, sawlogs, softwood logs } \\ \text { Sleepers }\end{array} \\ & \begin{array}{l}\text { Sleepers, hewn sleepers, girder-sized sleepers, sleeper offcuts } \\ \text { or 'roundbacks', specialist 'transom' and 'junk' sleeper pieces }\end{array}\end{array}$

Other disturbance

Controlled burning

TSI cypress

TSI hardwood

Wildfire
Clearing and burning, control bum, stacked and burned, top burning, top bumt, top disposal and control, whole stack bumt

Non-commercial thinning (applies to cypress only)

Culling and ringbarking (applies to hardwood only)

Bumt growth cut down, fire, wildfire

Note: TSI is the acronym for Timber Standard Improvement, a silvicultural treatment which kills unwanted trees by felling, ringbarking or poisoning.

The maps shown for Pilliga West (Figure 1) illustrate how this information may be manipulated by the Geographic Information System. Textual information, in this case compartment numbers from which cypress sawlogs have been harvested, may be used to illustrate 'compartment level detail' (Figure 1A). It is not necessarily the case that all of the area from within each compartment was affected (compare same compartments in Figure 1B). However mapping at this scale does provide an indication of the extent of activity across the forest or the landscape.

Information derived from hard copy maps can be used to locate more exactly where this logging took place-referred to as 'sub-compartment level detail' (Figure 1B). However, due to a lack of records (see below) this patch level information may not always be available (compare Figures $1 \mathrm{~A}$ and $1 \mathrm{~B}$ ). The data can also be used to show disturbance events at varying time intervals (Figures 1C and 1D) and may be incorporated with yield information (not given here) to indicate the intensity of timber removal. 


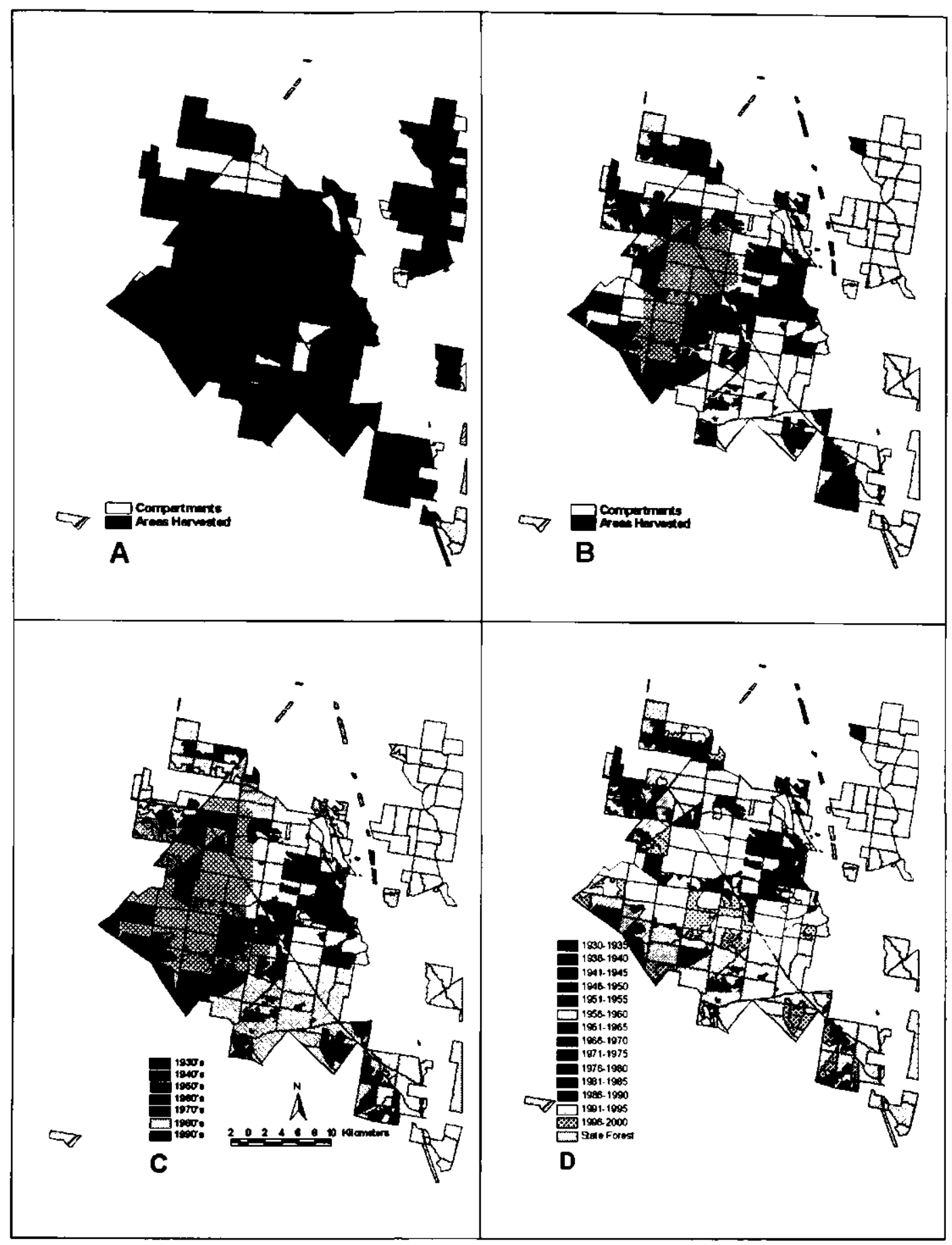

Figure 1. Mapping to date-Cypress pine sawlogs harvested from Pilliga West since 1932. Compartment level data shown for all years combined (A); and sub-compartment level data shown for all years combined (B), ten year (C) and five year intervals (D). 
Table 5. Factors to consider when deciding whether to map management history at the compartment or sub-compartment level

\begin{tabular}{lll}
\hline Factor & Compartment & Sub-compartment \\
\hline Focus & Landscape & Patch \\
Data usually available? & Yes & Not always \\
Relative cost & Less expensive & Much more expensive \\
Reliability & Less reliable & $\begin{array}{l}\text { More reliable provided mapping is } \\
\text { accurate }\end{array}$ \\
\hline
\end{tabular}

Mapping of textual and hard copy spatial information can be used to investigate management history. The level of mapping chosen will be a compromise between management focus, data availability, cost and reliability (Table 5). Absence of a record cannot necessarily be interpreted as nil activity for that area; records may have been lost or destroyed, or inconsistencies or omissions in record keeping (e.g. areas disturbed not specified, compartment numbers not identified) can render the data unusable.

\section{Conclusion}

Regardless of improvements in technology (e.g. use of Geographic Information Systems for easy retrieval and display of information) the accuracy of maps produced is reliant on the quality of information available. The challenge is to ensure that data collected in the future is at a scale and a level of precision suitable for application at different levels across the landscape. As data entry and keeping of records becomes more streamlined, information on past disturbance will become a more powerful tool to inform management and for researchers involved in flora and fauna projects.

\section{References}

Allen, M.R. 1998. Case studies of three gpress pine forests in the Lacblan and Bogan River catchments, Forbes Forestry District on Back Yamma, Euglo South and Strahom State Forests. Pennant Hills, NSW: State Forests of New South Wales.

Curby, P. 1997. Narrandera study on Buckingbong, Gillanbah and Matong State Forests. Forest History Project for State Forests of New South Wales. Pennant Hills, NSW: State Forests of New South Wales.

RACAC-Resource and Conservation Assessment Council 2000. Disturbance History Mapping Project-Brigalow Belt South. NSW Westem Regional Assessments. Sydney, NSW: Resource and Conservation Division, Department of Urban Affairs and Planning. van Kempen, E. 1997. A bistory of the Pilliga gpress pine forests. Pennant Hills, NSW: State Forests of New South Wales. 

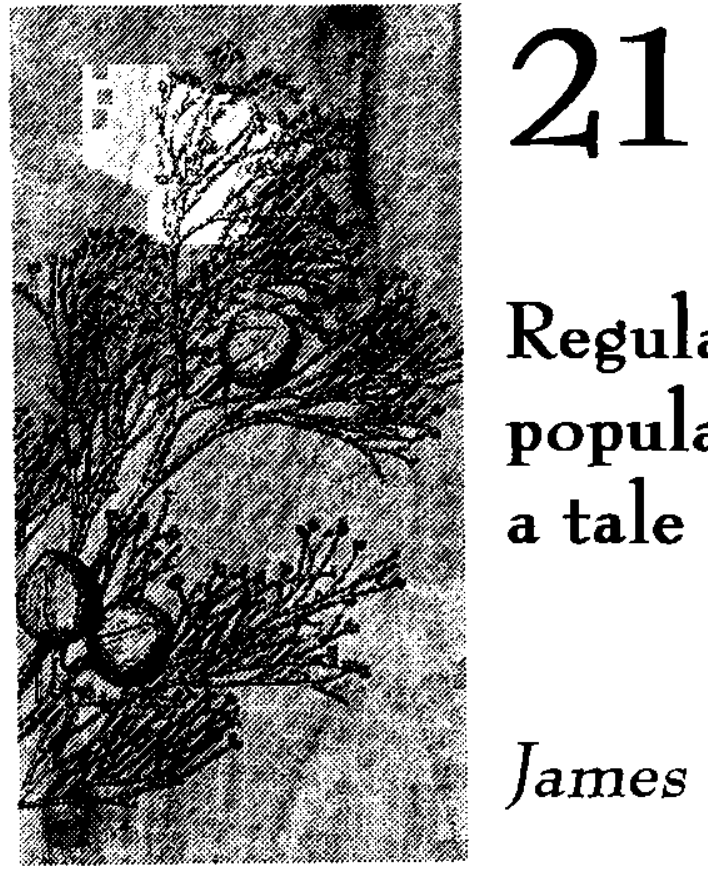

\section{Regulating Callitris} populations:

a tale of two pineries

\section{James C. Noble}

\section{Introduction}

Several species of Callitris occur throughout the arid and semi-arid rangelands of Australia (Cunningham et al. 1992). Here, attention is focussed on the population dynamics of two particular species, mallee pine (C. verrucosa, syn. $C$. preissii spp. verrucosa) and white cypress pine ( $C$. glaucophylla). Mallee cypress pine rarely occurs as extensive stands and is more likely to be found scattered throughout the semi-arid mallee communities used primarily for pastoralism (Noble 1984). These communities are usually dominated by several mallee eucalypt species including Eucalyptus socialis, E. dumosa and E. incrassata, with mallee cypress pine commonly found in dunefield or sandplain habitats where the understorey is dominated by porcupine grass (Triodia scariosa) (Noble 1989a). Much of the open mallee country was selected by the larger pastoral companies during the 1860s (Heathcote 1977). Settlement of more arid areas such as the Scotia mallee country adjoining South Australia (average annual rainfall generally ranging from $200-225 \mathrm{~mm}$ ) occurred much later, some leases not becoming available until the $1920 \mathrm{~s}$ (Noble 1984). Since Europeans arrived on the scene, successful regeneration of mallee cypress pine has only rarely been observed in areas or microsites, e.g. within Triodia hummocks where seedlings are protected from browsing by the European rabbit (Oryctolagus cuniculus) and by sheep (Sims and Carne 1947, Sims 1951, Cochrane and MacDonald 1966). 
White cypress pine (C. glaucophylla), however, is particularly abundant throughout some semi-arid regions such as the western plains of central New South Wales. Not only was this region perceived by early pastoral explorers during the mid-nineteenth century as excellent grazing country, the predominantly light-textured soils and favourable rainfall regime at the time together provided favourable regeneration conditions for this species. As early as the 1870 s, widespread concern was being expressed about pine 'invasion', Surveyor Sharp reporting in 1881 that large areas back from the Lachlan river had become densely covered with small pine scrub (Sharp 1881). By 1887, Jervis (1956) estimated that 'The Great Central Scrub' covered an area of 128000 square kilometres.

Later sequences of above-average rainfall, such as those experienced during the mid 1950s and 1970s, coupled with heavy grazing pressures and widespread ring-barking of associated eucalypts, e.g. poplar box (Eucalyptus populnea) and red box (E. intertexta), have also led to significant recruitment of pine seedlings. So-called 'wheatfields' with densities around 900000 seedlings per hectare-some up to 3.25 million-were not uncommon (Lacey 1972, 1973). Unlike most plant populations, these dense conifer populations did not self-thin over time, remaining instead in a state of 'suspended vegetation'. Such high-density stands essentially excluded any herbaceous understorey thereby reinforcing many pastoralists' perceptions of white cypress pine as a serious 'woody weed' (Noble 1997).

Precise reasons for this major shift in vegetation structure were not readily appreciated at the time. Charles Bean in his tour of the Western Division in 1909 described how forests of pine had appeared mysteriously in part of the country we had passed through' (Bean 1911, p. 101). Although some observers (e.g. Sharp 1881) noted that white cypress pine was particularly dense in areas where bushfires had not occurred for a long time, there was no concerted effort by pastoralists to re-introduce fire as a management tool. This aversion to the deliberate use of fire was due partly to an instinctive fear of large-scale fire. Even if deliberate burning was contemplated, it was only feasible after rare sequences of above-average rainfall when surplus herbage was available as fuel, an unlikely scenario given the high grazing pressures and increasingly dry conditions prevailing at the time.

Subsequent research in other semi-arid savannas throughout the world has clearly indicated the dominant influence of fire on vegetation structure and composition (e.g. Hodgkinson and Harrington 1985). However, interactions between fire and other processes such as herbivory and browsing are likely to be more critical in mediating the dynamics of woody plant populations than just fire alone (Archer 1996, Dublin et al. 1990). Whether such 
interactions involved native marsupials, both grazers (herbivores) and browsers (folivores), is unknown (Noble 1996). Nonetheless, mounting historical and scientific evidence suggests that a combination of light grazing by resident macromarsupials, i.e. red and grey kangaroos (Macropus spp.) 3570 kilograms in bodyweight, together with episodic fire, and subsequent browsing of regenerating woody plants by a range of macropod species, were together capable of maintaining savannas more open than those found today.

Browsing pressures, whether by direct decapitation of seedlings or defoliation of coppice regeneration, were probably imposed by both macroand mesomarsupials (bodyweights of the latter ranging from 1.5 up to 8 kilograms) (Noble 1996). Most of these animals are today considered as vulnerable, if not endangered, lying within the 'critical weight range' of 35 grams to 5.5 kilograms defined by Burbidge and McKenzie (1989). Many are now either totally extinct, extinct on the mainland, or regionally extinct and restricted to remnant populations. This paper discusses the relative significance of these interactive processes and canvasses scientific evidence in support of their likely roles as post-fire folivores regulating Callitris regeneration.

\section{Pine seedling predation: exclosure studies in mallee (Eucalyptus spp.)}

In 1978, a series of exclosures designed to exclude various combinations of vertebrate herbivores/folivores were established on Birdwood Station, some 30 kilometres east of Pooncarie. These were located in large experimental plots $(1000 \times 180$ metres $)$ dominated by porcupine grass and mallee eucalypts burnt 24-30 months earlier (Noble 1989b). Exclosures, each 10×20 metres, and associated control treatments, were replicated four times. Fencing details are outlined briefly as:

1. control (open to all vertebrates);

2. sheep only excluded ( 5 plain wire fence);

3. sheep, goats and rabbits excluded (upper barbed wire with hinged joint plus rabbit-proof netting below);

4. sheep, goats and kangaroos excluded (similar to (3) with an additional layer of hinged joint above); and

5. all vertebrates excluded (fencing as in (4) plus rabbit-proof netting). Mallee cypress pine seed collected on Birdwood Station during the 1979 autumn was germinated in the glasshouse at the CSIRO Rangelands 
Research Centre, Deniliquin. Germinants were later transferred into tubes and allowed to grow for a further 8 months before being transplanted into exclosures and control plots ( 6 per treatment) in the autumn of 1980. Transplanted seedlings were periodically watered throughout the first summer to minımise moisture stress during early establishment. Seedling survival was monitored at frequent intervals (about every six weeks) during the first year and occasionally (three times) during the following eighteen years. Survival percentages were analysed using a generalised linear model with binomial errors and logit link (Dobson 1990).

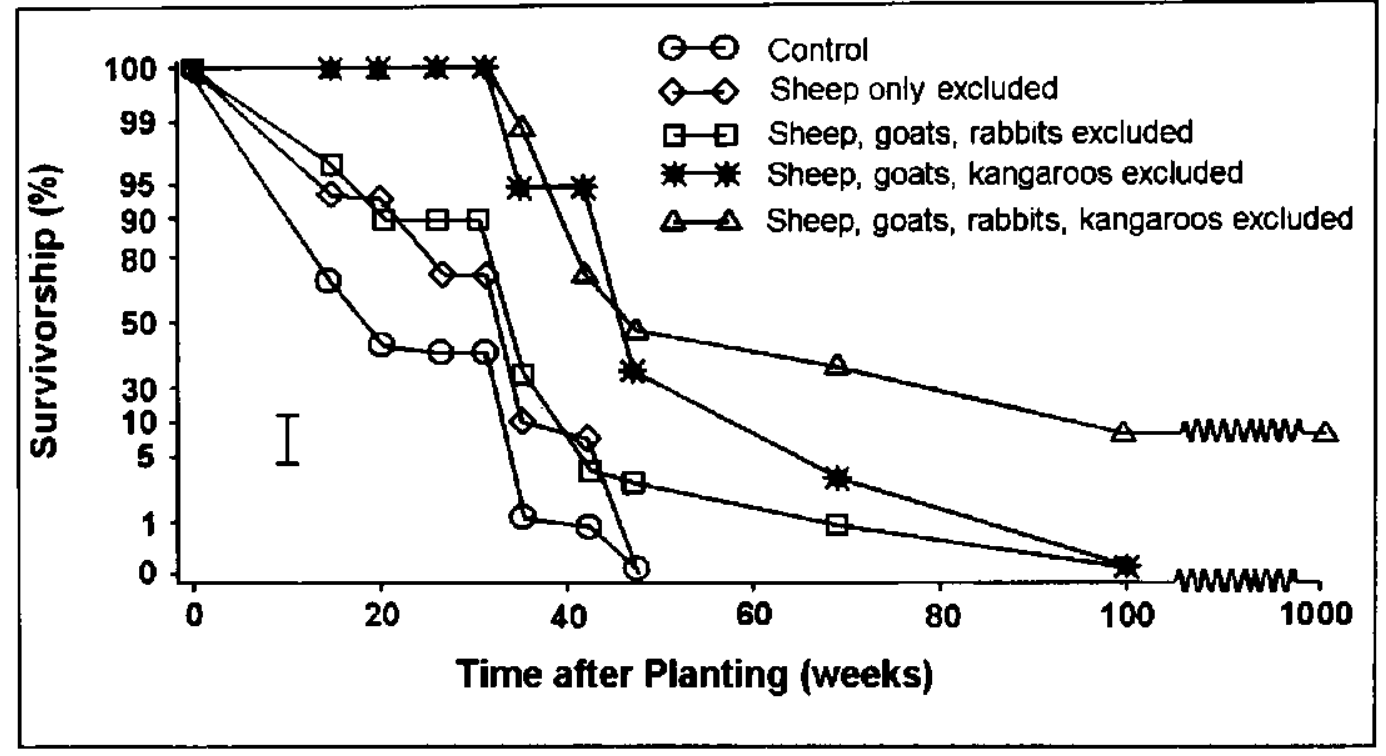

Figure 1.Survival of transplanted seedlings of mallee pine under contrasting browsing regimes. Birdwood Station, Pooncarie, NSW. The Y-axis is graduated on a logit scale while the bar represents average $2 \times$ standard error for each observation.

The survival of transplanted seedlings is shown in Figure 1. Pine seedlings were rapidly depleted in both controls and plots where sheep were excluded, with none surviving longer than 40 weeks. Seedling mortality was initially significantly higher in those plots where only kangaroos had access compared to those open to rabbits only, although ultimately all seedlings were eliminated in both these treatments after two years had elapsed. By then, however, 15 percent of the original transplanted seedling populations were still alive where all vertebrates had been excluded. After seventeen years, all had grown into small trees averaging 2.8 metres high. 


\section{Scrub biocontrol:}

\section{landscape ecology of the burrowing bettong}

Many of the mesomarsupials including the bridled nailtail wallaby (Onychogalea fraenata), the burrowing bettong (Bettongia lesueur) and brush-tailed bettong (B. penicillata) were once widely distributed throughout semi-arid Australia but are now restricted to small remnant populations. While it is now difficult to gain accurate information for many of these species as to habitat preferences and population sizes, one of these, the burrowing bettong, has left a conspicuous record of its past presence in certain habitats in the form of large excavated warrens (Noble 1993).

In 'hard red' landscapes of the West Darling region, large semi-circular warrens, some up to 30 metres in diameter, have been engtaved like giant intaglios across the landscape (Noble 1997). On Glenora Station, west of Louth, relict warrens within an area of about 4.5 square kilometres were located by three observers, one in a four-wheel-drive vehicle and the others on motorbikes, all of whom remained in radio communication as the area was traversed along parallel transects approximately 50 metres apart. As each warren was located, its dimensions (cross diameters), nominal condition class (based on warren definition and presence/absence of a central calcrete 'lens' 30-50 centimetres thick), and finally its position using a Global Positioning System were recorded. Warrens were classified as:

Class I: Well-defined, sub-circular ('horse-shoe'), perimeter mound with the central depression containing a distinctive calcrete lens.

Class II: Perimeter mound reduced in height, shallower central depression and surface of calcrete lens just visible.

Class III: General morphology (i.e. perimeter mound and central depression) further reduced with no calcrete lens visible.

Class IV: Warren microtopography very subdued, central depression and vestiges of perimeter mound only just visible.

Class V: Convex mound, semi-circular morphology absent with sites, especially on lighter-textured soils, often heavily re-worked by rabbits.

Spatial data were then plotted using a basic Geographic Information System (see Figure 2). The largest warrens (Class I) occurred most frequently $(30 \%)$ and appeared to parallel midslope contours where calcrete lenses are commonly found. Here pedogenic calcrete has been precipitated in favourable subterranean microsites through evaporation as soil water stops moving downslope after major rainfall events (Noble et al. 2001). The median 
diameter recorded for the warrens sampled on Glenora was 17.5 metres. If, hypothetically, there were an average of five burrowing bettongs per warren (e.g. two breeding pairs and one juvenile based on major entrances), putative population density at that site would be 35 bettongs per square kilometre.

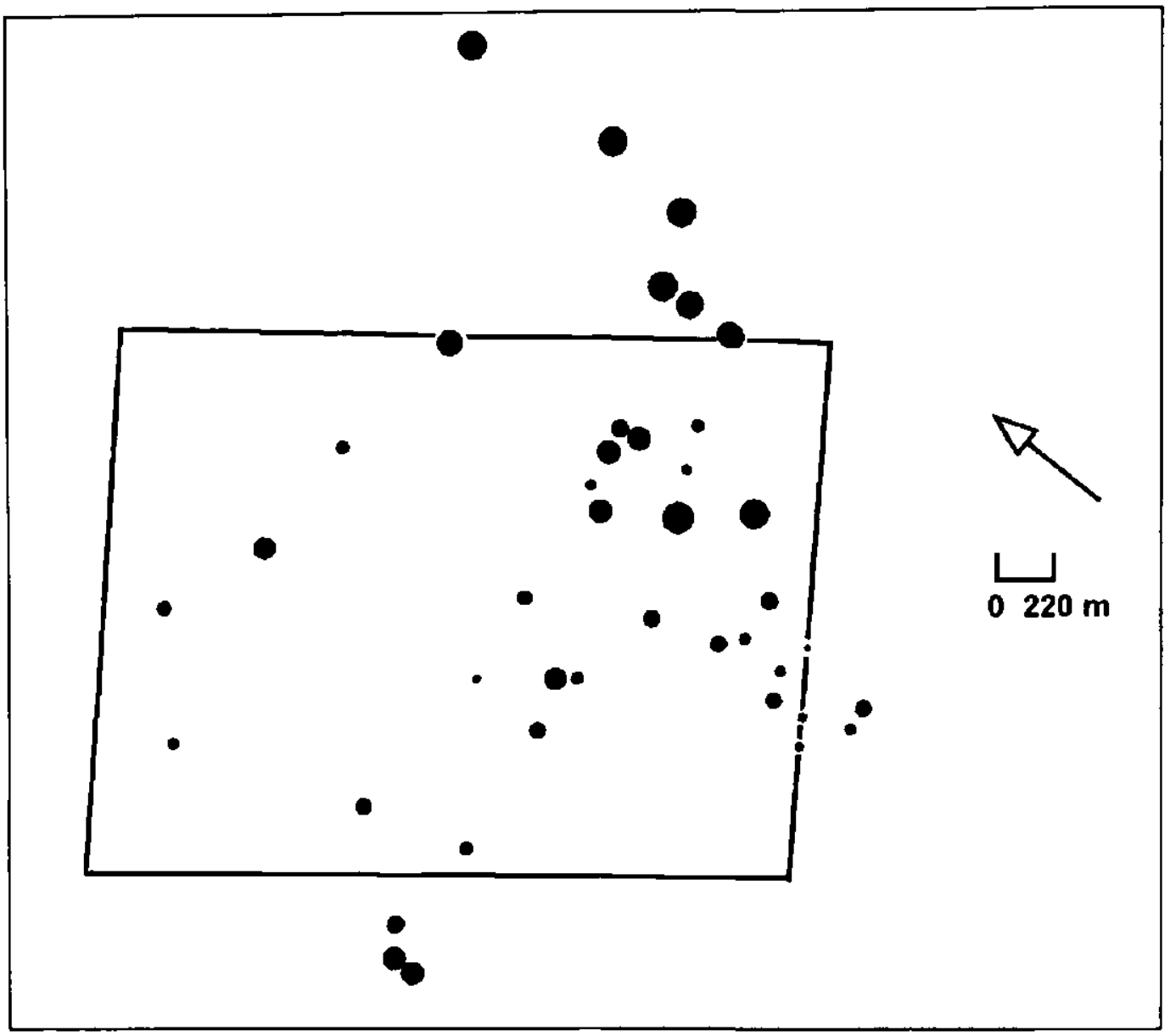

Figure 2. Distribution of relict warrens constructed by the burrowing bettong (Bettongia lesueur) in a 5 square kilometre study site on Glenora Station, via Bourke, NSW. Size of circle indicates relative warren size, the largest representing those around 30 metres in diameter.

Modelling studies using such imputed population data, together with information gleaned from various sources concerning the effects of fire, rainfall and browsing on the demography of woody scrub species, including white cypress pine, indicated the potential for two stable states to exist. One stable state is characterised by low scrub density maintained by periodic fire and bettong browsing while the other, a high scrub density state, would develop in the absence of fire or browsing by mesomarsupials (D. Hik and J. Noble, unpubl. data). 


\section{Discussion}

It is now generally accepted that episodic fire has had a dominant role in influencing the regeneration of many woody plant species in semi-arid Australia (Noble 1989a, Noble et al. 1997). Past studies of pine regeneration, however, have tended to focus more on seedling predation by rabbits and domestic livestock than on consumption by fire. Early exclosure studies in the Victorian Mallee (e.g. Zimmer 1944, Sims and Carne 1947, Sims 1951) found no regeneration of Callitris species outside rabbit-and stock-proof exclosures. Similar exclosure studies in other habitats including sourcebordering dunes on the Riverine Plain (Jones 1963) and monospecific Callitris forests/woodlands in southern Queensland (Johnston 1969) and central New South Wales (Lacey 1972), confirmed that seedling predation by the same vertebrates can also significantly impair recruitment of white cypress pine seedlings.

The small exclosures used in those early studies also inadvertently prevented access by local kangaroos. Larger exclosures (10×10 metres) were subsequently installed in the early 1980s in the Hattah-Kulkyne National Park in north-western Victoria to exclude both rabbits and kangaroos (Cheal 1986), resulting in both trees and shrubs regenerating. In Hattah-Kulkyne, very high concentrations of the western grey kangaroo (Macropus fuliginosus), around 25-33 per square kilometre, have been observed in preferred habitats whereas densities elsewhere normally average 4-5 per square kilometre (Morgan 1987 cited in Coulson and Norbury 1988). These and other observations on Birdwood suggest that macromarsupials such as the westem grey kangaroo, the dominant species found in mallee ecosystems and known locally as 'scrubbers', have been seriously underrated as browsers. These macropods are clearly capable of regulating regeneration of woody species such as buloke (Allocasuarina luebmanii), needlewood (Hakea tephrosperma) and cypress pine (Callitris spp.). In the past, they have been regarded more as herbivores. Their numbers increased significantly over the past century following extensive clearing of woodlands, establishment of permanent water supplies and the evolution of 'marsupial lawns' created by continuous grazing of domestic herbivores (Frith 1964, Newsome 1965, Noble and Tongway 1986).

Furthermore, browsing pressure by these macropods increased during droughts once the availability of grass forage fell below a threshold of 400 kilograms (dry weight) per hectare (Coulson and Norbury 1988). Caughley et al. (1985) found no significant response by resident kangaroos, again mainly western greys, to the increased herbage following prescribed fire in a large 
paddock (about 8000 hectares) of mallee on Tarawi Station in the Scotia country south of Broken Hill. Fire caused little change in kangaroo dispersion at this site since adequate herbage was available elsewhere following good rains. In both the Hattah-Kulkyne and Birdwood studies, browsing pressure by resident macromarsupials was accentuated by increasingly dry conditions in the early 1980 s culminating in one of the most severe droughts on record during 1982/83 (120 mm was recorded at Pooncarie for 1982 compared with the long-term annual median of $250 \mathrm{~mm}$ ). Pine seedlings on Birdwood were rapidly eliminated wherever plots were accessible to kangaroos.

Nonetheless, fire remains pivotal because of its role as a primary 'conditioning' process facilitating several other ecological processes. Not only can it promote seed germination and seedling recruitment in 'gaps', it also makes available previously inaccessible crown foliage, in the form of coppice and seedling canopies, for use as forage. Many terrestrial folivores such as the bridled nailtail wallaby (Onychogalea fraenata) are now known to be capable of digesting foliage often regarded as totally unpalatable, especially to domestic livestock (Ellis et al. 1992). There is now mounting anecdotal and scientific evidence supporting the proposition that periodic fire, reinforced by marsupial browsing, together regulated scrub regeneration. Rolls (1981) claimed that periodic fire followed by browsing of pine seedlings by rat kangaroos, probably the rufous bettong (Aepyprymnus rufescens), maintained much more open communities in the Pilliga Scrub than those existing today. With the eventual demise of these 'champion seedling eaters', together with changes in fire regime, the Pilliga has now become a forest of pine in many places. On Rottnest Island in Western Australia, exclosure experiments clearly demonstrated that when another mesomarsupial, the quokka (Settonix brachyurus), is prevented from gaining access to bumt country, there is rapid tree and shrub regeneration (Main 1992).

The relatively high densities of burrowing bettong warrens recorded at Glenora suggest that while they were all used at some time, a few were particularly valuable in providing important local refugia during drought. Nonetheless, it is impossible to know precisely how much local populations varied over time. Contemporary predator-prey models (e.g. Pech and Hood 1998, Sinclair et al. 1998) now provide the basis for integrated strategies to be devised for controlling major exotic predators such as the fox ( $V$ ulpes vmlpes) and the feral cat (Felis catus) over a considerable area. Hopefully at some stage in the future it may be possible to re-establish viable mesomarsupial populations in several key sites where appropriate experiments can be carried out to validate some of the hypotheses outlined in this chapter. 


\section{Acknowledgments}

The technical assistance provided by the late Ron Bawden, Ken Greaves and other members of the Research Support Group at the CSIRO Rangelands Research Centre, Deniliquin, during the mallee experiments, and later by Gil Pfitzner, Ian Curtis, John McMaster and Allan Reid, CSIRO Sustainable Ecosystems, Canberra, during the bettong studies, is gratefully acknowledged. Warren Müller, CSIRO Mathematical and Information Sciences, Canberra, kindly analysed the pine survivorship data from Birdwood shown in (Figure 1) while John Ive, CSIRO Sustainable Ecosystems, Canberra, prepared the distribution map shown in Figure 2. Gil Pfitzner produced the figures used in this paper while Dr Alan Newsome and the editors contributed helpful comments on an earlier draft of this paper.

\section{References}

Archer, S. 1996. Assessing and interpreting grass-woody plant dynamics. In J. Hodgson and A.W. Illius (eds). The ecology and management of grazing systems. Wallingford: $C A B$ Intemational.

Bean, C.E.W. 1911. The dreadnought of the Darling. London: Alston Rivers.

Burbidge, A.A. and McKenzie, N.L. 1989. Patterns in the modern decline of Westem Australia's vertebrate fauna: causes and conservation implications. Biological Conservation 50: $143-98$.

Caughley, G., Brown, B. and Noble, J. (1985). Movement of kangaroos after fire in mallee woodland. Australian Wildife Research 12: 349-53.

Cheal, D. 1986. A park with a kangaroo problem. Onyx 20: 95-99.

Cochrane, G.R. and MacDonald, N.H.E. 1966. A regeneration study in the Victorian Mallee. Victorian Naturalist 83: 220-6.

Coulson, G. and Norbury, G. 1988. Ecology and management of western grey kangaroos (Macropus fuliginosus) at Hattah-Kulkyne National Park. Arthur Rylah Institute for Environmental Research Technical Report Series No. 72. Melbourne: Conservation, Forests \& Lands, National Parks and Wildlife Division.

Cunningham, G.M., Mulham, W.E., Milthorpe, P.L. and Leigh, J.H. 1992. Plants of western New South Wales. Sydney: Jacaranda Press.

Dobson, A.J. 1990. An introduction to generalized linear models. London: Chapman \& Hall.

Dublin, H.T., Sinclair, A.R.E. and McGladen, J. 1990. Elephants and fire as causes of multiple stable states. Journal of Animal Ecology 59: 1,147-64.

Ellis, B.A., Tierney, P.J. and Dawson, T.J. 1992. The diet of the bridled nailtail wallaby (Onychoagalea freaenata). I. Site and seasonal influences and dietary overlap with the blackstriped wallaby (Macropus dorsalis) and domestic cattle. Willilife Research 19: 65-78.

Frith, H.J. 1964. Mobility of the red kangaroo, Megaleia rufa. CSIRO Wildife Researbh 9: 1-19.

Heathcote, R.L. 1977. Pastoral Australia. In D.N. Jeans (ed.). Space and society. Sydney. Sydney University Press. 
Hodgkinson, K.C. and Harrington, G.N. 1985. The case for prescribed buming to control shrubs in eastem semi-arid woodland. Austratian Rangeland Joumal 7: 64-74.

Jervis, J. 1956. The exploration and settlement of the Westem Plains. Joumal and Proceedings of the Royal Historical Society 42: 1-15.

Johnston, T.N. 1969. The effect of sheep and rabbit grazing on regeneration of white cypress pine. Australian Forest Research 4: 3-12.

Jones, R.M. 1963. A note on cypress pine regeneration on prior streams. Journal of the Soil Conservation Service of New South Wales 19: 184-6.

Lacey, C.J. 1972. Factors influencing the occurrence of cypress pine regeneration in New South Wales. Forestry Commission of NSW (Technical Paper No. 21).

Lacey, C.J. 1973. Silvicultural characteristics of white cypress pine. Forestry Commission of NSW (Research Note No. 26).

Main, A.R 1992. Management to retain biodiversity in the face of uncertainty. In R.J. Hobbs (ed.). Biodiversity in mediterranean ecosystems in Australia. Chipping Norton: SurreyBeatty \& Sons.

Newsome, A.E. 1965. The distribution of red kangaroos, Megaleia nufa (Desmarest) about sources of persistent food and water in central Australia. Australion Joumal of Zoology 13: 735-59.

Noble, J.C. 1984. Mallee. In G.N. Harrington, A.D. Wilson and M.D. Young (eds). Management of Australia's rangelands. Melboume: CSIRO.

Noble, J.C. 1989a. Fire regimes and their influence on herbage and coppice dynamics. In J.C. Noble and RA. Bradstock (eds). Mediterronean Landscapes in Australia: mallee ecosystems and their management. Melboume: CSIRO.

Noble, J.C. 1989b. Fire studies in mallee (Eucalyptus spp.) communities of westem New South Wales: the effects of fires applied in different seasons on herbage productivity and their implications for management. Australian Joumal of Ecology 14: 169-87.

Noble, J.C. 1993. Relict surface-soil features in semi-arid mulga (Acacia aneura) woodlands. Rangeland Joumal 15: 48-70.

Noble, J.C. 1996. Mesomarsupial ecology in Australian rangelands: burrows, bettongs (Bettongia spp.) and biocontrol of shrubs. In N.E. West (ed.). Rangelands in a sustainable biosphere. Proceedings of the 5th International Rangeland Congress, Salt Lake City, Utah. Denver. Society for Range Management.

Noble, J.C. 1997. The delicate and noxious scrub. Canberra: CSIRO Wildlife and Ecology.

Noble, J.C. and Tongway, D.J. 1986. Herbivores in arid and semi-arid rangelands. In J.S. Russell and R.F. Isbell (eds). Australion soils: the buman impact. St Lucia: University of Queensland Press.

Noble, J., MacLeod, N. and Griffin, G. (1997). The rehabilitation of landscape function in rangelands. In J. Ludwig, D. Tongway, D. Freudenberger, J. Noble and K. Hodgkinson (eds). Landscape ecology, function and management: principles from Australia's rangelands. Melboume: CSIRO Publishing.

Noble, J.C., Gillen, J., Jacobson, G., Low, W.A., Miller, C. and Mutitjulu Community (2001). The potential for degradation of landscape function and cultural values following the extinction of mitika (Bettongia lesueur) in Central Australia. In A Conacher (ed.). Land degradation in Australia. Dordrecht: Kluwer Scientific Publications.

Pech, R. and Hood, G.M. 1998. Foxes, rabbits, altemative prey and rabbit calicivirus disease: consequences of a new biological control agent for an outbreeding species in Australia. Joumal of Applied Ecology 35: 434-53. 
Rolls, E.C. 1981. A million wild acres: 200 years of man and Australian forest. Melboume: Thomas Nelson.

Sharp, Surveyor 1881. Counties of Cunningham (North Condobolin), Blaxland (Euabalong, Mt Hope and northward), and Mouramba (Nymagee and westward). Reports from surveyors as to the spread of pine and other scrubs. In Votes and Proceedings of the New South Wales Legislative Assembly During the Session of 1881. vol. III. Sydney: Government Printer.

Sims, H.J. 1951. The natural regeneration of some trees and shrubs at Walpeup, Victorian mallee. Victorian Naturalist 68: 27-30.

Sims, H.J. and Came, R.S. 1947. Mortality of Murray pine trees in the Victorian Mallee. Australian Joumal of Science 9: 188-9.

Sinclair, A.R.E., Pech, R.P., Dickman, C.R., Hik. D., Mahon, P. and Newsome, A.E. 1998. Predicting effects of predation on conservation of endangered prey. Conservation Biology 12: 564-75.

Zimmer, W.J. 1944. Notes on the regeneration of Murray pine (Callitris spp.). Transactions of the Royal Society of South Australia 68: 183-90. 

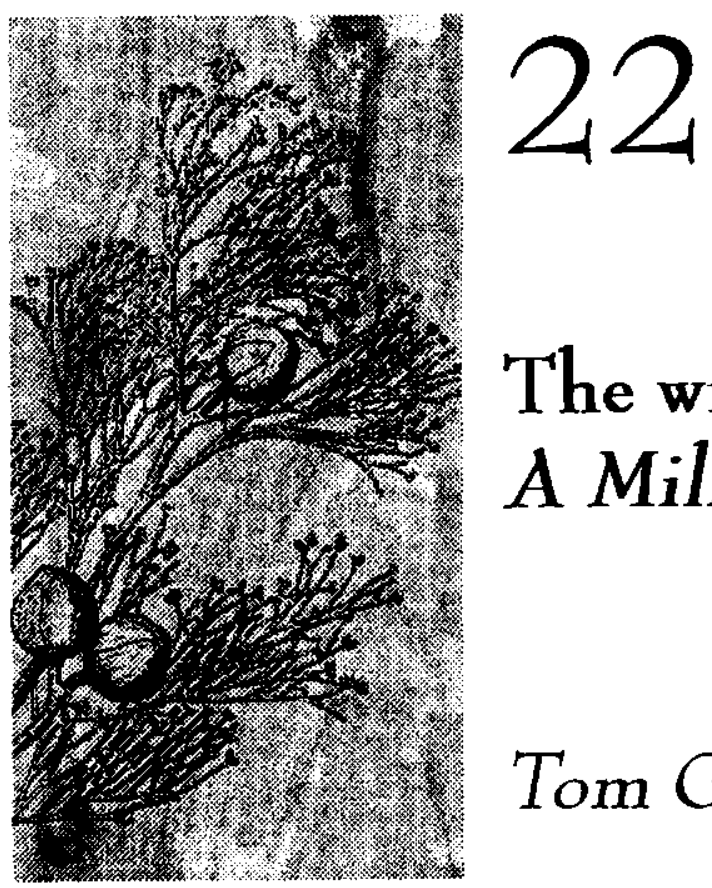

The writing of A Million Wild Acres

\section{Tom Griffiths}

Soon after A Million Wild Acres was published in 1981, I read the book and realised that I had encountered something momentous. I felt as Les Murray did when he wrote of Rolls's book that he read and re-read it 'with all the delight of one who knows he has at last got hold of a book that is in no way alien to him' (Murray 1997: 158). I was living in Melbourne and I was moved to write to the author, whom I had not met and could hardly dream of ever meeting, and who seemed to me to live in an extraordinary, magical and especially dynamic place. It was slightly mystifying because I recalled once as a child in the 1960 s being driven through Coonabarabran, and I could remember the vast tracts of the Pilliga Scrub (as it was disdainfully called) rolling endlessly past the car window. It had not seemed extraordinary, magical and especially dynamic then. Had it changed? Had I changed? Had this man's book opened my eyes? All of the above. I had never before realised how strongly words on a page could animate actuality.

In my mid-twenties and freshly home from my first trip overseas, I wrote Eric Rolls a brief letter, telling him that $A$ Million Wild Acres was one of a handful of books about Australia that I would like to put in the hands of any visitor to help them understand my country. Now I would make even greater claims for it. I think it is the best environmental history yet written about Australia, and I would especially hope it could be read not just by 
visitors but by all Australians. I wrote that letter to Eric almost twenty years ago not because I wanted or expected a reply, but because I had to write it. But he did reply! He told me of the work he was doing on his history of the Chinese in Australia, offering me a brief, vivid snippet of his life. I now know that Eric gets lots of letters like mine, and that he replies to more than I would have thought possible. I've been looking at some of them in the archives. Eric's papers, mountains of them, are in at least three libraries. And amongst them you can find testimonies from people moved by his books to write, even though writing does not always come easily to them. Some people normally unfamiliar with written words are clearly living Eric's words. One wrote in stumbling script: "This is the first book I have ever read. Thank you for writing it. I enjoyed it so much I am now going to try reading other books.' (Rolls 2000a) Another wrote at more length, but also with spelling difficulties:

Dear Eric,

Just a note or a few words, to say how much I liked your two books, $A$ Million Wild Acres, They All Ran Wild. The best I have seen. I will get your other books and read them soon.

I would of liked to been with you, and read all the books and papers, and places you went to get all the true information. A great bit of work. I do not no how many times I bave read 'A Million Wild Acres'. I no I bave read They All Ran Wild' twice last month.

... I lived all my early life at Pilliga. I will tell you more later. I like reading History of Australia. And you love the Bush, and no all about it.

... If you are ever over this way call in and have a yam, and stay with your family. We have plenty of nom. I will write again to you soon, bope you get some rain. 'And keep uriting', all the best.

Yours truly...

K.C. 1989

And here are the words of another reader, admitting (like me) that she did not often write fan letters, but in this case could not stop herself:

...I enjoyed your book more than I am capable of expressing. You made the Pilliga come alive on the page and I bope you make trillions.

[She also wrote] On nearly every page I found something to exclaim over mostly I exclaimed how on earth did this man have time to fit in the farming! L.A. c.1995

Well, I think Eric often wondered that himself? He has written of the constant battle between acres and words, the farm as both a source of his originality and a growing distraction. As the success of $A$ Million Wild Acres both settled and unsettled his life, he did a stocktake. 
On my sixtieth birthday I happened to be working out how many years it would take me to write the next five books: say another three years on this one, eighteen months, two years on that, seven years' research and writing on the next big one. Then I realised with considerable shock how old I would be. I decided from then on to work words a day every day instead of acres. (Rolls 1989:11)

In his book Doonvays: $A$ Year of the Cumberdeen Diaries, Eric told us of his workspace, his desk, as it was at his farm on Pretty Plains. He always wrote with his back to a broad window, the words in front of him, the acres behind. 'The imagination works better against a blank wall', he says. But the sun on his back warms him, reminds him of the outside world he is trying to capture on paper. Of his Silky Oak desk, he says: 'everything on it knows its place. Words come to it that I am not expecting.' On his desk were a pile of handwritten notebooks, eleven dictionaries and books of words, a typed outline of the current book. He added five new pages of writing to the pile each day. Empty blocks of lined A4 paper sat beside him, and the two fountain pens that had written all his books. In front of him was a large, disconcerting pile of letters that need answering, and that we now know he will probably eventually get to. There was a big splinter of fragrant sandalwood, a tail feather from a Swamp Pheasant, little soapstone turtles from China, a branding iron and two blocks of Mulga. (Rolls 1989)

Now imagine him there and listen to Eric wrestling with both the words and the acres in the late 1970s as the book he has always wanted to write materialises into chapters, but never fast enough. These are excerpts from his letters to Sue Ebury, the editor at Thomas Nelson Publishers with whom he worked on A Million Wild Acres and also to his agent, Tim Curnow. And remember as you listen to them that Eric has firmly declared the following:

Unless you feel so intensely about writing that you are prepared to murder anybody who stops you getting to your desk, it's no use thinking of being a writer (Rolls 2000a).

When Eric offered the idea of the book to the publishers in October 1974 (and they accepted it immediately and enthusiastically), he hoped that it might be finished in seven months (Rolls 1974). On the first of June 1976, with years of experience, observation and research behind him, he takes a deep breath: 'The frame of the book is already mostly planned-it is only wording to be considered.' And three months later: 'I've got within a fortnight of beginning to write and am getting excited.' A year later, in September 1977, Eric writes that he has not signed the Nelson contract yet because he is 'frightened harvest is going to fall on me like a guillotine when there are two chapters still to go. I don't want to let anyone down and enough money 
has come in to keep me writing until harvest-so I'll just do my damndest and see how far I get.' 'Most days [he says] I read about six hours and write for six - if it is not ready on time it won't be for lack of trying.' (Rolls 197680)

But the acres continually interrupt the words. Another year later, in September 1978, he explains:

I lost three precious weeks writing when the lad who was working here burnt himself as he began crop spraying - he is still off work but I'm back to the writing. The tractor we use for odd jobs was bumt completely. I had to finish spraying then do the summer ploughing. It is cruel changing over from writing to farming unexpectedly. And I'd been concentrating so hard I was not even living in this century when it happened.

'One nearly gets torn in halves sometimes trying to lead two lives', he exclaims. But "Without the farm there would have been no book, even if it delayed publication.' (Rolls 1976-80)

In his house, he virtually re-enacted the settlement process he was describing. Just getting the right pioneers into the right places at the right time was a demanding and arduous job. He recalled:

I lined all the men up against one wall- 37 men-each had a pile of papers, each named, all their years, and then I had the map at the other end of the room. I'd pick up a pile and march the man across the room to his place on the map... You had to see him getting there. (Rolls 2000a).

A reviewer of the book, the environmental historian and philosopher, George Seddon, later described these early chapters of the book as like the Book of Genesis, with its endless "And Joktan begat Almodad, and Sheleph and Hazarmaveth, and Jerah". There is [continued Seddon] a walk-on-walkoff cast of thousands, and the detail is numbing - but this is the Pilliga Book of Genesis, and I think the author was right to put it all in.' (Seddon 1982: 59)

In July 1979, Eric reflected on a job nearly complete:

The end of the Pilliga book is in sight, thank God. I'm appalled that it has run so long over time. Each estimate I made seemed certain-I know how much I can do a day. Then what seemed certain plans for the farm would come unstuck and I'd have to do a couple of months hard work. It is hard not to go on writing and leave it. But one has to be practical. If we went broke in the middle of the book it would cost more time than ever. And there is not much leeway on the land now. Fixed costs are enormous and increasing. As much as I love the farm, 
it will have to be sold. It will not only cost me too much time but too many books. I'm also afraid it will cost me years of my life. It is excruciatingly difficult each time coming back to an unfinished chapter. So much reading has to be done again-days of it.

And on the fourth of October that year, he records: 'I've just written the last word of the Pilliga book.' (Rolls 1976-80)

Three years of writing here, in the available spaces. But for years before there had been the source material of experience, of life on the soil, of walking and talking the forest, collecting scats to analyse animal hairs, learning the names of plants often for the first time, mastering in words the craft of the timbergetters. And all that correspondence! Eric's papers spill out with letters requesting and receiving information: To the Curator of Mammals at the Australian Museum, 'How rare is the rat kangaroo?' ... and could they possibly as one old timer attested be seen hopping about in dozens on a moonlight night'? To the Patent Trade Marks and Design Office in Canberra, 'Can you tell me anything about early patents for barbed wire in Australia?' To the Secretary of the Royal Agricultural Society Kennel Control, 'Can you tell me if there is still a breed of dog known as a staghound?' To the President of the Quirindi and District Historical Society, Do you know exactly how the old acetylene lights worked?' To Mrs King of the Tamworth Historical Society, 'Have you any local information about the construction of George Clarke's stock yards at Boggabri-near Barber's Lagoon?' (Rolls 1973-80).

It is the detail that matters, and it is getting it right that matters, too. 'Much of the game of writing history', he declares at the start of the book 'is keeping it true.' (Rolls 1981: vii) And keeping it true, for Eric, means not just finding out what happened, but in finding a sense of wonder about it, and in understanding it in such detail and with such precision that he can make the story live. Use of the active tense--and his books bristle with it-requires quite specific knowledge. The passive tense, by contrast, allows slippage and can mask ignorance. Rolls's prose is bracing and vivid. 'At times', he says, 'I can even smell what I'm writing about.'(Rolls 2000a) There is also a 'swagger' to his style - and he consciously cultivates it-because it enables him to tell a story with conviction. This careful accretion of authentic organic detail generates the power of $A$ Million Wild Acres. Les Murray celebrated this in a wonderful essay called 'Eric Rolls and the Golden Disobedience'. Eric's disobedience, explained Murray, was his freedom to sidestep received literary sensibilities, his ability to transcend the conventional boundaries between fiction and non-fiction, and between humanity and nature. Les Murray considered the book to be like an extended, crafted campfire yam in which 
everyone has the dignity of a name, and in which the animals and plants have equal status with humans in the making of history. Murray compared its discursive and laconic tone to the Icelandic Sagas (Murray 1997). Through his democratic recognition of all life, Rolls enchants the forest and presents us with a speaking land, a sentient country raucous with sound.

Eric recently reflected on the writing of this book:

I began to think that the whole forest seemed to be an animate thing, with voices, and that perhaps I ought to give the trees themselves an identity, and then I thought that's absolute bloody nonsense, you've got a wonderful story to tell, just tell it in a straightforward manner in the best way it can be written. One of the reviews said that the whole book reads as though the trees themselves were telling the story, which delighted me. If I'd tried to do it that way, the book would have been hopeless. (Rolls 2000a)

One of Eric's earliest public performances made nature animate. Every Friday afternoon at his kindergarten in Grenfell, his teacher Miss Postlethwaite used to tell the class stories. She would do this from her slightly elevated stage, with a mat at her feet. But she was rather dull. So one day, five-year-old Eric put up his hand and said 'Miss Postlethwaite I'd like to tell a story this afternoon'. She said 'Alright, come out here.' Eric was prepared and knew what he would do. It was sowing time on the farm, so he went up the front and pretended he was a grain of wheat. He jiggled down into the ground, buried himself in the earth, and pulled the mat over his body. Then the roots grew and the legs stuck out. Then leaves sprouted and the arms waved. The little boy wriggled and danced. As Eric recalled, 'So I grew up, and a header came along and stripped me, and then the sheep went into the paddock and I got eaten'. He started telling stories every Friday afternoon, and adults began to join the gathering too, making quite an audience. 'I realised that telling stories was a good thing to do if you did it properly.' (Rolls 2000a)

The central story of $A$ Million Wild Acres is a simple and compelling one, told richly and persuasively. It is, in Eric's words, about the growing of a forest. This conference addresses his insights into the Pilliga and their applicability elsewhere: papers assess tree density (contemporary and historic), fire regimes (Aboriginal and settler), and the meaning and pattern of disturbances. Eric's original achievement was to confront and provoke Australians with the idea that in many areas of the country, landscapes that had once been grassy and open are now densely vegetated, that there might be more trees in Australia now than at the time of European settlement, that forests-which we so readily and romantically see as primeval-could often 
be the creation of our own act of settlement. How many trees make a forest, he asked? 'It is not a paradox that the fires that once kept our forests open should now cause them to grow denser.' (Rolls 1981: 248) Eric brought an observation that was commonplace in local lore forcefully into the scientific and historical literature. However that thesis might be challenged in various details, we will not now retreat from the fundamental and enduring truth at the heart of it. Eric offered us not only a scientific insight, but a poetic one, and the two visions are necessarily intertwined. Here I am concentrating on A Million Wild Acres as a literary and cultural achievement, and focusing not so much on the scientific significance of the book's argument, as on its poetic and political dimensions.

Ross Gibson, who (with John Cruthers) made the award-winning film Wild based on Eric's book, described his history of the Pilliga as an 'unruly tract of local history' and 'a deliberately feral book' (Gibson 1993). Feral is a fitting adjective for the work of this author of that other landmark book, They All Ran Wild. Eric is fascinated by the meaning of 'wild'. It is often used to describe nature that is seen to be untouched and pristine. But for Eric-a farmer- 'wild' nature is feral, mongrel, hybrid nature, nature stirred up, nature enlivened by human presence and intervention; it is dynamic, historical nature (Gibson and Cruthers 1990). So the forest that he grows in the pages of his book is 'concentrated' and volatile.

'A Million Wild Acres' was Sue Ebury's title. Eric's own earlier suggestions had celebrated the novelty of the nature he describes: 'Pilliga', 'An Exaggerated Country', 'Unexpected Forests', 'Phoenix Forest', or 'Ungentle Men Unsettled Land'. At first Eric had his doubts about Sue's suggested title: 'I'm a bit dubious about another title with wild in it', he replied, '-I am partly civilised.' He is fascinated by the invaders, the cattle, rabbits, foxes, their adaptability and sheer vigour even as they wreak damage. And he respects the 'wild men' too, the ungentle white settlers of Australia. He is impatient with those who disown them. 'This book', he writes in A Million Wild Acres, 'is not written by a gentle man'.

The book challenges the traditional contrasts of European settler thinking about nature. It revolutionises those assumptions that disturbed nature is somehow always lesser nature. Such views bring Eric into conflict with aspects of the green movement. At the same time as recognising the fragility and integrity of native ecosystems he wants to acknowledge the creative ecology of invasion. This relish for the fecundity of life and an irrepressible optimism also underpin Eric's joint advocacy of the causes of nature conservation, on the one hand, and human immigration to Australia on the other. He is determined to see the creativity of encounter. 
Poetry always stirs politics because of its spareness and power. Rolls's argument that Australia was not a timbered land that has been cleared has been seen by some people as a dangerous idea. So when we assess the shadow-boxing between Ryan, Ryan and Starr (1995) and Benson and Redpath (1997) -about Aboriginal burning and the density of forests-we have to remember it is an exchange that is more political than scientific. The first was a selective and undiscriminating report sponsored by the NSW Farmers' Association that strategically linked $A$ Million Wild Acres to modern debates about tree clearing and controlled burning. When launching the book at the Association's General Council meeting, Ian McClintock stated that 'this book will prompt readers to question whether the image promoted by the Green movement of the Australian landscape before the white man is correct ... One of the great frustrations in the environmental debate is that the green movement wants to take the Australian landscape back to some point in the past that may never have existed' (Lucas 1997: 203). The report has been used by opponents of vegetation clearing control regulations, especially those introduced in NSW in August 1995. Its perceived political influence earned it more attention than it deserved. An opposing study by Benson and Redpath criticised Ryan, Ryan and Starr and also sought to discount Rolls's book because of the legitimacy and support his Pilliga story could be seen to give to the recent clearing of native vegetation. Read Eric's book rather than these simplifying summaries.

When Rolls was writing $A$ Million Wild Acres, the conservation battlegrounds in Australia were the rainforests, most notably at Terania Creek in 1979 (Dargavel 1995: 184-5). As Rolls acknowledges in his final chapter, woodchipping was also an issue and had become shorthand for indiscriminate forest clearing and exploitation. Rolls considered it a necessary industry committed to unnecessary destruction (Rolls 1981: 402). So his book was written in the midst of those campaigns, when forests were depicted as timeless and primeval, and human disturbance meant the destruction of trees. He wrote a detailed regional study showing that forests could also be the creation of settlement. He wasn't the first to notice this phenomenon: the anthropologist, naturalist and explorer Alfred Howitt, for example, presented his observations of the increasing density of forests in Gippsiand to a scientific audience in 1890 (Howitt 1890). The power of A Million Wild Acres was that it gave voice to a myriad of these earlier observers. And Rolls told a multi-causal story of how it had happened in one region, a place he knew intimately. He saw system and pattern and creativity in it. His book attracted little scientific or green criticism for over a decade and a half, awaiting another political context. By the mid to late $1990 \mathrm{~s}$, the frontline of 
conservation battles had moved from the logging of old growth forests on public land for timber to the clearing of native vegetation on private or leasehold land for farming. In this new context, Rolls' argument appeared dangerous and had to be countered. Perhaps his own complex anti-Green (but environmental) politics made him even more of a target.

Scientific attitudes to Aboriginal fire management are also revealing. Benson and Redpath, by reading evidence too literally and in the service of a certain politics, join a long line of Australian denials of the significance and sophistication of Aboriginal burning. David Horton's The Pure State of Nature (2000) is the latest. As Judith Wright wrote in reviewing A Million Wild Acres:

It is as strange to me as to Rolls that some scientists and others still dispute the effect of Aboriginal fire-management, or even that there was such management. Again and again in my own reading of stockinspectors' reports in the Queensland of the sixties and seventies, there is reference to the change in pasture growth and shrub cover which followed the vanishing of the Aborigines and the fierce protectiveness of squatters for their timber fences, huts, yards and vulnerable slow-moving flocks of sheep. But no doubt such evidence is too much that of laymen to be trusted by academic ecologists. (Wright 1982)

The politics that underlie this issue are so powerful and embedded, and have such a long history, that they are often unconscious (Griffiths 1996). Scientific disdain for Aboriginal ecological knowledge was often racist; now it is sometimes simply humanist, or I should say anti-humanist. In other words, the same suspicion can apply to settler knowledge-indeed to local knowledge of any kind-because it is human, anecdotal and apparently informal. (For a local correction of Benson and Redpath, see Whitehead $(2000))$. It is one of the jobs of environmental historians to address the politics (cultural and disciplinary) as well as the science, and especially to show their witting and unwitting interaction.

So the debate about Rolls's work, at this conference and elsewhere, sometimes presents itself as a clash of disciplinary styles, a methodological tension between the sciences and the humanities. The very qualities for which literary scholars and cultural historians celebrated Rolls's book-its vernacular and organic dimensions, holism, and narrative power-can be seen by others to diminish its scientific credentials. What I happily recognise in Eric's book as narrative logic, Benson and Redpath dismiss as 'conjecture'. They underestimate and misunderstand the distinctive skills of the writer and humanities scholar. Narrative is not just a means, it is a method, and a rigorous and demanding one. Benson and Redpath also enact a 
conventional academic strategy by accusing $A$ Million Wild Acres of being 'popular' and unrecognised in 'the peer-reviewed scientific literature', thereby implying that a book that is well-written and has a wide (and lay) audience could not possibly also be reliable and scholarly. Rolls's resistance to referencing-something I understand but disagree with him aboutmakes him more vulnerable. Several scientific studies prompted by Rolls's work, and seeking to counter it, strain for an 'objective method' over and above the 'subjective' one of reading historical documents and listening to reminiscence, thereby bypassing a rich, tangled archive in favour of a constructed, countable one (Paull and Holmes, this volume). We need both, together. It is extraordinary that, at the same time as discounting $A$ Million Wild Acres, Benson and Redpath plead for a detailed regional study of forest dynamics!

I raise these issues about the science-humanities divide because so many people are attracted to forest history and environmental history, and indeed to Eric's books, because they like to work across that boundary as creatively and as constructively as they can. In my own work, I am deeply indebted to scientists, and I write my history out of respect for them. Eric continually pays tribute to scientists, and his latest book-his Australia: A Biography Volume One (Rolls 2000b)-is dedicated to them.

Eric has never been afraid of a dangerous idea. He likes to tell it as he sees it. It gets him into trouble of course. One of his essays for the Independent Monthly, many of which were later gathered in From Forest to Sea, was an exposé of the use and abuse of water resources. Eric told the editor, Max Suich, of how his research provoked a distinctly watery threat:

I had no idea that things are as serious as they are, or that it will take so long to rectify them, or that there are such murderous forces at work opposing change. It is quite startling to be told 'you better pull your punches or you'll end up with concrete shoes'. I haven't pulled any punches. (Rolls 1992a)

And he is just as ready to run the gauntlet of the conservationists as he is the developers or the bureaucrats. He is especially critical of all of them if they are 'short on history' (Rolls 1992b). There is a fearlessness about Eric's work, as well as a swagger. And there is a complexity to A Million Wild Acres behind the compelling narrative power. It is a truly original work, yet it speaks directly to so many people; it is unique and pathbreaking, yet it also seems to represent an organic integrity and a common vernacular. That is Eric's extraordinary artistic achievement. That is why readers write to him, and why reviewers compare $A$ Million Wild Acres to the Book of Genesis, or 
a campfire yam, or an Icelandic Saga. That is why it is possible for this book to be the first book someone might ever read.

\section{References}

Benson, J.S. and Redpath, P A. 1997. The nature of pre-European native vegetation in south-eastern Australia: a critique of Ryan, D.G., Ryan, J.R and Starr, B.J. (1995) The Australian landscape -observations of exploners and early settlers. Cunningbamia, 5(2): 283-328.

Dargavel, J. 1995. Fashioning Austrakia's forests. Melbourne: Oxford University Press.

Gibson, R. 1993. Enchanted Country. World Literature Today, 67 (3): 471-6.

Gibson, R and Cruthers, J. 1990. WILD-Outline for a Film. In E. Rolls, Papers, Mitchell Library, Box 37A (69).

Griffiths, T. 1996. Hunters and collectors: The antiquarian imagination in Australia. Cambridge University Press.

Horton, D. 2000. The pure state of nature. Sydney: Allen \& Unwin.

Howitt, A. 1890. The Eucalppts of Gippsland. Melboume: Royal Society of Victoria.

KC. 1989. Letter to Eric Rolls, 3 November. Rolls Papers, Mitchell Library, Box 37D (69).

L.A. c. 1995. Letter to Eric Rolls. Rolls Papers, Mitchell Library, Box 37E (69).

Lucas, D. 1997. Growing a 'Useful' History: Narrative, Ecology and Resource Management. Public History Revien 5/6: 200-8.

Murray, L. 1997. Eric Rolls and the Golden Disobedience. In L. Murray, $A$ working forest: selected prose. Sydney: Duffy and Snellgrove.

Rolls, E. 1973-80. Letters requesting information. Rolls Papers, National Library of Australia, Box 1, Folder 3.

Rolls, E. 1974. Letter to Anne Godden, Publisher, Thomas Nelson (Australia) Ltd, 11 October. Rolls Papers, NLA, Box 10, Folder 67.

Rolls, E. 1976-80. Letters to Sue Ebury and Tim Cumow. Rolls Papers, National Library of Australia, MS 7027, Box 1, Folder 2.

Rolls, E. 1981. A million wild acres. Melbourne: Thomas Nelson.

Rolls, E. 1989. Doonvays: a year of the Cumberdeen dianies, Sydney: Angus \& Robertson.

Rolls, E. 1992a. Letter to Max Suich, 6 October. Rolls Papers, Mitchell Library, ML $1719 / 83$, Box $26(69)$.

Rolls, E. 1992b. Questioning a few fervent opinions. Island, 53: 26-31.

Rolls, E. 2000a. Interview conducted by Tom Griffiths, Newcastle, 19 February.

Rolls, E. 2000b. Australia: a biography, Vol. 1, St Lucia: University of Queensland Press.

Rolls, E. Papers. Mitchell Library, Sydney.

Rolls, E. Papers. National Library of Australia, Canberra.

Ryan, D.G., Ryan, J.R and Starr, B.J. 1995. The Australian landscape -observations of explorers and early settlers, Wagga Wagga: Murrumbidgee Catchment Management Committee.

Seddon, G. 1982. Dynamics of Change. Overland, 87 (May 1982): 55-60.

Whitehead, J. R. 2000. A discussion paper on human impacts on the vegetation of the Coonabarabran Shire. In Coonabarabran Shire Council, Vegetation Management Plan, Vol. 3: Appendices, Coonabarabran: Shire Council.

Wright, J. 1982. A chronicle of white settlement. Island Magazine, 12: 44-5. 

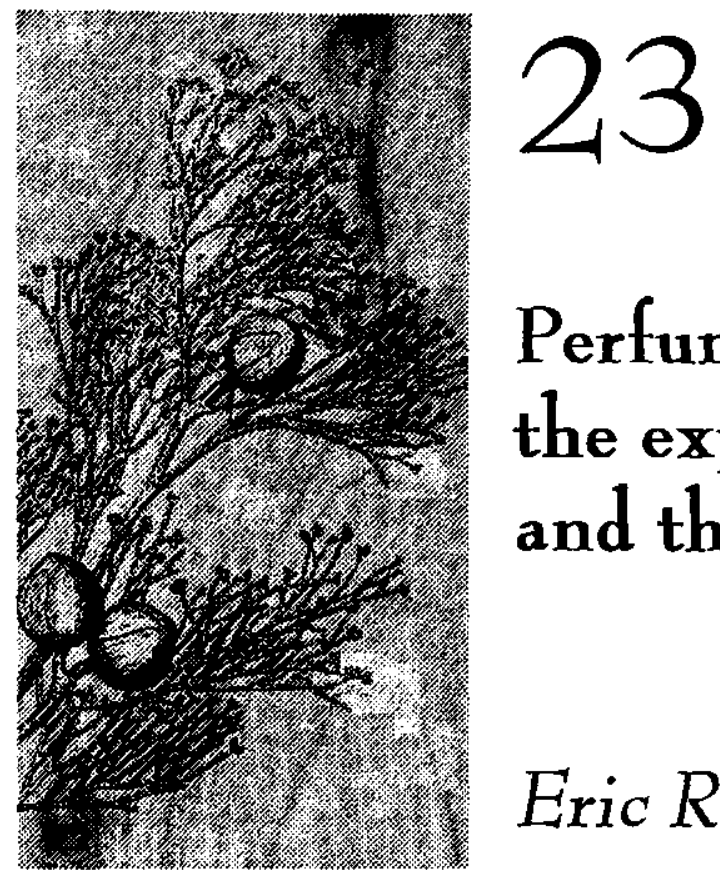

\title{
Perfumed pines: the exploited and the exploiter
}

\author{
Eric Rolls
}

Over the last hundred years the conjoined Pilliga forests have established themselves as the biggest area to celebrate the perfumed pines. Until well into the twentieth century cypress pine was considered for its perfume. Comprehensive tests for many oils were applied to hundreds of species of Australian trees and shrubs. But the lemony scent that the pines yielded could be got in much greater quantity from Backbousia trees and shrubs and the Andropogon genus of grasses.

Aboriginal Australians applied infusions of pine leaves or bark to rashes and to the whole body for diarrhoea. Europeans put twigs of black cypress pine in horse feed as an anthelminthic. Pharmaceutical manufacturers still use the resin that stumps yield in such extraordinary quantity to coat pills required to dissolve in intestines instead of the stomach.

But its timber is its glory. It was highly praised by the jurors of the London International Exhibition in 1862:

A coniferous wood of remarkable character, chiefly for the great size of the superbly-figured slabs that it yields under certain conditions of growth. In such specimens the heart-wood extends nearly across the bole, having a narrow defined sap-wood. The colour is a rich brown, with large bold waves of darker brown, bold cloudiness and nipples and ribands. This is indeed a superb and very peculiar wood. 
The Pilliga forests held some wonderful timber, old greys that would cut beautiful, yellow, fifteen-centimetre boards four metres long without a single knot in them. In the 1920 s when A. E. Collins, once a well known chain of country stores, was putting up a new store in Wee Waa, now a cotton town on the Namoi River, a local miller offered to cut white cypress pine joists thirty by thirty centimetres and sixteen metres long.

Pines with a couple of hundred years on them came to life in open forest; they are closing it in heavy forest. I love cypress pine because it lives life passionately. At pollination time when hundreds of cones go off together with a sharp crack and spurt brown pollen a metre into the air, the whole tree shivers. And they seem to be aware of what is happening around them. They react to disturbance with extraordinary growth, seeming to declare, 'If I can't grow as I'd like, nothing else will, I'll exclude it'.

One species of Callitris, macleayana, lives (there are so few left I could say lived) as scattered individuals in rainforest and along rainforest edges in northern New South Wales and southern Queensland. In a few places they grew with some dominance. Among the Scrubby Creeks and Tea Tree Creeks and Bean Creeks and plentiful Cedar Creeks on detailed maps there is an occasional Pine Creek. If they had room on good soil, these pines grew huge, forty-five metres tall with trunk diameters of 1.2 metres. The unusual reddish bark was so thick and furrowed it gave them the name of 'Stringybark Pine'. The wood was yellow but unfigured. Its ease of working made it popular with builders. Round logs of smaller trees made excellent wharf piles or fence posts.

Another species of Callitris (probably columellaris but species names have changed so often I am uneasy about giving them), very similar to that growing here, grew in a few patches on the coast, particularly at Brunswick Heads. It was all milled so early there is little memory of it ever growing there.

Where did the common white cypress pine grow and how did it grow? Here in the Pilliga forests it grew as impressive, well-spaced trees. James Ward, appointed the first forest ranger for the district in 1877, estimated there were four mature pines to the hectare with twenty-five young pines in the several reserves declared by 1878 . They were areas chosen for their timber.

Even by the 1920s there were not big areas of thick pine. Gordon Burrow and B. Priestman left a valuable record of the transect surveys that they carried out at that time. In Pilliga West, Burrow noted 'two white cypress pine trees to the acre [ 5 per hectare] of 10 inches and 11 inches [ 25 $\mathrm{cm}$ and $28 \mathrm{~cm})]$ diameter and two more of 12 inches $[30.5 \mathrm{~cm}]$ and over'. 
Priestman perceived eight or so mature pines to the acre as 'a thick stand'. One area he described as 'magnificent advanced Pine forest' held 20.4 to the hectare of trees twenty-five centimetres and over.

Outside the Northern Territory I have come across only one early record of a stand of original white cypress pine substantial enough to excite the observer. In 1832 the explorer Thomas Mitchell, in the upper Bogan River country south-west of present Narromine, reported 'forests of magnificent pine trees ... The height and girth of some of the callitris trees were very considerable. Thus, we found that Australia contains some extensive forests of a very good substitute for the cedar of the colony'.

In 1815 George William Evans, exploring the country just east of present Cowra in central New South Wales, wrote he was glad to observe ... useful pine trees from one inch to three feet in Diamiter [sic], as straight as arrows, some of them at least forty feet high before the branches begin to shoot out'. The rapid growth of pine that forced graziers out of the Pilliga was not wholly a phenomenon of European settlement. In a trip down the Lachlan in 1817 Oxley found what he called 'very thick cypress scrub' near present Weethalle, about sixty kilometres west of West Wyalong.

Parliamentary papers from 1880 record an astonishing story of new pine growth on land disturbed by European livestock and changes in buming. In September 1882 the Member for Balranald told of 10 million acres 44 million hectares] taken over. Of one man's 280000 acres 'some 230000 acres of it are overrun ... and rendered almost useless'. Numbers of other Members had similar stories. A new law forced leaseholders to clear pine scrub.

Only twenty-eight years later at the 1908 Royal Commission of Inquiry on Forestry, opinions had changed radically. John MacPherson, manager of Deepwater near Wagga Wagga, was asked for an estimate of the value of the pine destroyed during the last ten years: 'Perhaps thousands of pounds worth ... it seems criminal to destroy it as it has been done.' Almost a hundred years later, a slowly grown white cypress pine with a butt diameter of thirty centimetres or more is now worth $\$ 100$ as a standing tree. Those landowners, principally Queenslanders, wise enough to have saved them are finding them considerable assets. The return more than doubles if the owner does his own cutting and snigging to a dump. One hundred and thirty thousand round pine logs of even size cut from an unthinned forest near Narrandera were consigned to build houses in East Timor.

Between 1917 and 1920 Chinese carpenters built several tropical houses in the Edith River district north-west of Katherine framed with round white cypress pine, economically sawn lengthways and immaculately morticed and jointed. One was still standing when Elaine van Kempen and I were there a 
few years ago. The house is a long, high, wide rectangle of galvanised iron, floored with stone. Big sections of the walls push out like awnings. The doorways are nearly two metres wide. Within the living area are two separate bedrooms that one can walk around as though they are pieces of furniture. Their walls are of bamboo laths laced through with wire and topped with bamboo lattice.

Chinese builders everywhere cut their own timber. One finds many references to Chinese use of sawpits. I am very doubtful that Chinese would have used this European method, they had their own way of doing every job that they took on. I think the term 'sawpits' was applied loosely to their own different technique, the one still in use in China. It is less work, it is just as effective. They do all the work above ground. A log stand usually built around a convenient group of trees holds the log to be sawn at an angle with one end on the ground and the other one-and-a-half to two metres off it. The top man guides the saw and walks backwards down the log, but the bottom man works in a sitting position facing the opposite way to the man on top and holding a reversed handle. As the saw bites in, he slides along on his buttocks. That position keeps his face out of the sawdust. When he no longer has room to work, they lever the bottom of the log off the ground and farther up the platform.

The Northem Territory had very big stands of Callitris intratropica both on the mainland and on offshore islands. Though darker in colour than the southern species, its timber is highly aromatic, beautifully-figured and the most termite-proof of all. Yet when the South Australian government was building Palmerston, the first town in the Northern Territory, they wanted nothing to do with the magnificent local timber. At enormous expense they sent up Jarrah from Western Australia to frame the buildings. Termites a centimetre long found it so attractive that after a few years the resident reported that he doubted a dray load of Jarrah fragments could be found. Despite that disaster, when the contract was let for the Darwin-Pine Creek railway in 1887 , the Government specified Jarrah sleepers. Fortunately the contractors ignored the silly condition and used whatever timber was handy to the line, so many pine sleepers were laid. Apart from resisting termites, the northern pine is particularly long lasting when laid on the ground.

Chinese quickly realised the quality of the timber and cut it both for export and the local market. In 1879 they cut for the Government on Indian Island, a long island in Bynoe Harbour. When the contract expired, they went back on their own account and cut the lot. In 1881 they were cutting at a place called The Pinery, fifty kilometres north of Pine Creek. For buildings on Florida Station that formed in the Roper River area, they cut and sawed 
pine along the shores of the Glyde Inlet which carries the Glyde and Roper rivers into Castlereagh Bay on the north coast of Arnhem Land.

Fearing that supplies would disappear too quickly, the Government forbade indiscriminate cutting and brought in a licensing system. Every timbergetter had to hold one. The Chinese reacted as they did for golddigging, bought a licence for the headman only. In 1885 that cost a Palmerston storekeeper a lot of money. During September 1884 J. Langdon Parsons, Government Resident, heard that Chinese were cutting on Cobourg Peninsula. He asked E.O. Robinson, manager of the failing run, to investigate, and if they did not hold licences, to seize the timber, mark it with the broad arrow and bring it to Palmerston. Robinson arrived with two boat loads. Parsons wired Richard Baker, the South Australian Minister of Justice and Education, 'Shall I proceed against these unlicensed wood cutters ... my fear is we may have to keep twenty-six men in gaol for two months as they won't pay five pounds if they have it.' At that time South Australia administered the Northern Territory. Baker replied, 'As the act of seizing the timber is illegal I do not think it will be well to move further in the matter unless the Chinese commence proceedings against Robinson or yourself. Parsons asked, 'It was the crown's property when standing did it cease to be the crown's when cut? Does illegal felling create a right of property? Please advise me as to procedure as there are other cases of timber felling'. Baker advised, 'The alleged cutting of timber does not change the property but you are assuming the illegality'. He suggested that the legal way was to try the offenders, then if they were found guilty, the magistrate or judge could justly order the handing over of the timber.

All these men had come down from the goldfields in July to look for work in Palmerston. There was no water for washing gold and there was a frightening amount of sickness among the hungry. There was no work in Palmerston either. A Chinese syndicate formed to take advantage of the plentiful cheap labour on a timbergetting venture. Ty Lee Young, the only one of the partners to go to the Peninsula, took out a licence for himself only. Yee Kee, a storekeeper, fitted them up with tools, six months' rations and a big supply of flour and tobacco to keep the Aboriginal Australians in good temper.

Robinson became concerned when Aborigines told him the Chinese were shooting the company's buffaloes for meat. Although they were camped sixty kilometres from his home, they were still on Coburg Cattle Company lease. By Aboriginal runner he sent a note threatening to prosecute if they continued to shoot buffaloes. Eventually Ty Lee Young came to see him and arranged what meat he wanted for a payment of $£^{1}$ a week. Robinson told 
him that by law he should have a licence for every man though the cutting of timber was outside Robinson's control either as manager or as tide-waiter.

On 9 December Baker advised what seemed a fair solution, "If the timber is sold and a sufficient amount is retained by the Government to pay costs of seizing and carrying timber and other expenses, to pay license fee for cutting timber and a fine of $£^{5}$ for each man engaged without a license the balance should be handed over to the Chinamen with an intimation that in future no such leniency will be shown.'

Foolishly, and perhaps in desperation-Yee Kee the storekeeper was standing on them-the Chinese continued work. On 16 January 1885, Parsons wired:

After being twice warned they continued cutting and secreting timber. They secretly landed one cargo here at night ... in consequence of repeated defiance I recommend timber be wholly confiscated.

Baker approved. Yee Kee, the storekeeper, ended up well out of pocket.

Lily Ah Toy, well-known member of an old Darwin family, told me that her grandfather Moo Yet Fah once cut logs at Port Essington. He had his own junk to carry them but, for reasons that did not survive in family stories, somebody burnt it.

In 1903 a syndicate of Hong Kong businessmen began to cut pine, paperbark and stringybark for export to China. They employed Aboriginal labourers, Chinese timbergetters and European carriers and managers. A man named Hamilton was in charge. In September he was in Palmerston to buy wagons and 30 heavy horses. The loggers had 2000 trees down and Cooper, the only carrier, could not keep up to them.

In the Northern Territory Times of 15 January 1904 a correspondent told of a trip to Malay Bay, the scene of the logging about 30 kilometres east of the Bowen Strait between Croker Island and Cobourg Peninsula. He was on the ship that carted the wagons round. They unloaded them in pieces into Petrel, an old sailing boat which Cooper owned. He was a buffalo shooter and trepang fisher who had turned carrier for some quick certain profit. The horses, trucked to Pine Creek then driven overland, had arrived a few days before. They were tethered in a clump of paperbarks to wait their harness, also carried on the ship. It had been unloaded higgledy-piggledy in one considerable heap and the two drovers who were to become the additional carriers, had to sort it for match and fit. Five hundred logs were already down on the beach, beautiful timber without a pipe or any sign of rot, 6 to 12 metres long, 60 to 90 centimetres in diameter at the butt. Cooper said he had not yet brought down the big logs. Strangely, there is little tide in that 
bay, but there is a wide shelf of shallow water so each steamer load of two thousand logs had to be rafted out over the shallows and winched on board.

The camp for ten Chinese loggers was five kilometres inland near the stand of timber. They had built neat bark huts six metres by six metres. Melons, beans and cucumbers were already well advanced in their garden. Given the slightest opportunity, Chinese always had good food.

There is little white cypress pine now left in the Northern Territory. People have asked me why Pine Creek was so named. Elaine van Kempen and I spent a couple of days driving round rough tracks looking for pine. Eventually we found one, a distorted little tree out of reach of fire on the top of a rocky hill. Even if the pine was over-harvested last century, that would make no difference to the lack of it now. It is not a long-lived tree. If the mature trees had not been harvested they would be dead now, anyway. What happened was that there was no regrowth. Pine is prolifically selfperpetuating under the right conditions but unlike the majority of Australian plants it cannot tolerate much fire.

Aboriginal Australians burnt early in the Dry in the cooler months of the north, they burnt in the Wet if there was a chance to stop grass growing to a wild height that was difficult to walk through and impossible to find game in. Between May and August the land was a patchwork of gentle fires. When Europeans moved cattle in they disrupted Aboriginal burning but they themselves burnt huge areas at the end of the Dry to allow new growth to come through quickly on the first showers. The weather was hot, the grass had grown three metres high then fallen over and died in a thick mat. The fires were devastating. What white cypress pine survived in the Territory is on the top of steep granite hills where neither fire nor loggers can reach it.

A polished white cypress pine floor seems to be alive. The wood glows yellow and the brown knots swirl in it. Like narrow-leaved ironbark (Eucalyptus crebra), the other wonderful timber of the Pilliga forests, white cypress pine has too often been relegated to structural work; sleepers and posts in the case of ironbark, framing in the case of white cypress pine. The best way to celebrate the perfumed pines is to revive admiration of their timber. 


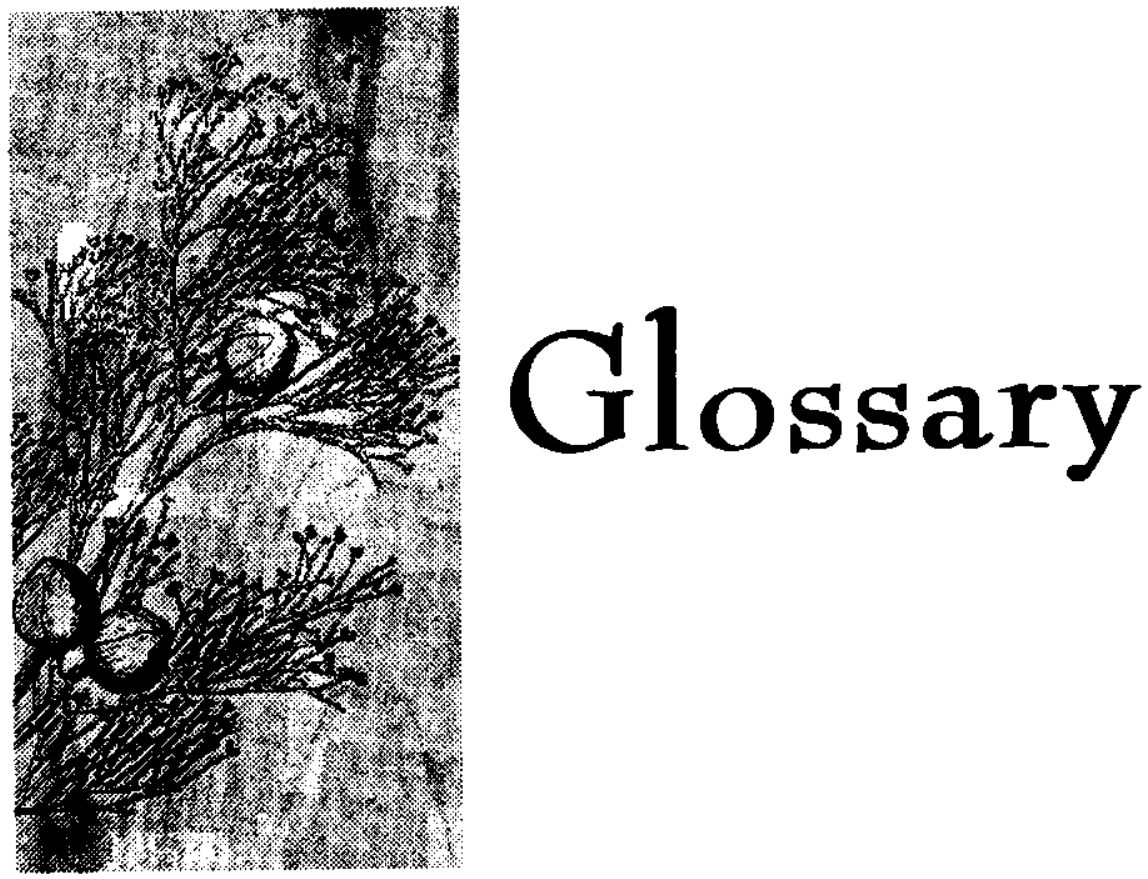

$\mu \mathrm{m}$ micron; $10^{-6} \mathrm{~m}$

aeolian deposits materials transported and layed down by the wind.

Alfisols (Order,USA Soil Taxonomy); soils with a subsoil enriched by transported material.

alluvium unconsolidated surface material deposited by running water.

AMS The use of an accelerator to measure the relative balance of carbon 13 and

14 isotopes in a carbon sample. The decay of carbon between these isotopes is a precise atomic clock allowing the age of samples to be estimated.

analogue something similar to or comparable with something else.

antediluvian belonging to the period before the Flood, having taken place within

the period of Noah's life.

anthelminthic a drug used to remove parasitic worms (helminths) from the host. autochthonous a feature, especially of sediment, which is not transported to the site but formed in situ (c.f. allochthonous).

avulse jump. Refers to the rapid change in course of a river or creek.

basalt fine-grained dark basic igneous rock; occurs mainly as lava flows.

bedrock the in situ rock material below a soil.

biodiversity the varieties of life forms.

biogeography the study of the geographical distribution of living things.

biomass the weight or size of individuals, species or populations forming a given population, food-chain level or inhabiting a particular area.

bioregion an area or region having distinctive flora and/or fauna. Australia is

divided into 80 bioregions for assessment purposes.

bioturbation disturbance of soil material by animals. 
bomb pulse The period since atmospheric nuclear bomb detonation (starting in 1945 ) when the relative balance of carbon 13 and 14 isotopes was dramatically changed and the gradual changes are recorded in wood and can be very precisely dated.

broom heath vegetation. Usually less than 2 metres tall.

cactoblastis moth small moth, the larvae of which feed on the prickly-pear, a problem, introduced cactus in Australia.

calcrete a pan (hard or cemented layer) of nodular gravel in a soil profile composed of calcium or magnesium carbonate.

Callitris (cypress pine) the genus in the Family Cupressaceae that includes Callitris glaucophylla which is the most widespread in the arid zone.

cambium a layer of cells giving rise to the growth in diameter of a plant.

carrying capacity the maximum population of a given species that can be maintained indefinitely in a given stable environment.

catchment an area which drains all the rain water falling on it by river to a lake or sea. Its boundary is defined by a ridge beyond which the water flows in the opposite direction.

chenopod shrublands community of plants which have characteristics such as waxy leaves, the ability to shed leaves during dry periods, etc., giving them drought and salt tolerance.

clay fraction particles smaller than $0.002 \mathrm{~mm}$, mainly composed of clay minerals. claypan a compacted soil layer comprising dense clay.

cluster analysis numerical technique in which objects are divided into discrete groups.

colluvium slope-derived material or sediment.

complacency the term used to describe a tree with a consistent rate of growth through time. This consistency in growth is unlikely to be sensitive to environmental changes of interest, such as climate.

conglomerate sedimentary rock formed from rounded, water-worn pebbles.

core the narrow $(5 \mathrm{~mm})$ transverse section of a tree trunk cut to expose a section

of the tree-ring sequence from the bark to the pith of the tree.

correlation the degree to which one variable is related to another (statistics).

cosmopolitan flora plants which are found worldwide.

cross-bedded inclined beds of depositional origin in sedimentary rocks. Formed

by wind or water depositing sediment in the lee of a ripple or dune.

cross-dating the matching of patterns in ring widths or other ring characteristics among several tree-ring series to allow the reliable identification of the exact year in which each tree-ring was formed.

crucifers member of $F$. Cruciferae; cabbage family.

dbh diameter at breast height, 1.3 metres above ground level.

deglacial period the period at the end of the last glacial period during which the continental ice sheets of North America and Europe melted until the beginning of the Holocene, when the ice sheets reached their present extent.

Approximately 18000 to 10000 years ago. 
dendrochronology the science that uses tree-rings dated to their exact year of formation to analyze temporal and spatial pattems of processes in the physical and cultural sciences. Literally, dendron $=$ tree, chronos $=$ time, $\operatorname{logos}=$ the science of.

dendroclimatology the science that uses tree-rings to study and reconstruct the past and present climate of an area. Example: analyzing ring widths of trees to measure rainfall.

dendroecology the science that uses tree-rings to study factors that affect the earth's ecosystems. Example: analyzing the effects of competition on tree growth by studying changes in ring widths over time.

dendrogram tree diagram used to display results of a cluster analysis; illustrates the degree of similarity between the objects being clustered.

dicotyledon plant with two cotyledons (seed leaves); member of the Dicotyledoneae, the larger of two classes into which the flowering plants are divided. Other structural features distinguishing this class from the Monocotyledoneae include netveined leaves and stem vascular tissue in the form of a ring of open bundles.

dieback death of trees, probably from many different causes including drought, insect defoliation, root-rot, etc.

dip the angle by which a planar surface deviates from the horizontal.

disk the transverse section of a tree trunk cut to expose the entire circumference of the tree.

duplex soil a soil with a sharp change in soil texture between the A and $B$ horizons ; example: sand over clay.

earthy fabric (of soil) material is coherent and has an aggregated appearance. The soil particles are coated with oxides and/or clays and are clumped around soil pores.

edaphic of the soil from the point of view of plant growth.

embryology the study of the development of embryos.

endemic species species confined to a given region.

exotic species foreign or from elsewhere.

extant species existing.

false ring the tree-ring that forms within a yearly cycle and therefore appears to add an extra year to the chronology. These are characteristic of hypersensitive trees.

fan gently inclined or level landform, usually at the foot of a slope, with radial slope lines inclined away from a central point. As a result of a build up of material.

faunal casts material excreted by small animals e.g. worms.

fining-upward trend deposition in sedimentary layers having coarser material at the base and a gradual decrease in sediment size towards the top.

flashy discharge a stream which has long periods of very low or no flow and intermittent short flash floods.

floodout a flat, inclined radially away from a point on the margin of a stream channel, formed by overbank stream deposits. 
fluvial activity of and deposition by running water.

fragipan a silica cemented earthy pan or denser layer in soils, cemented when dry but brittle when moist.

friable (of soil) easily manipulated into crumbs or cultivated; crushes easily under gentle to moderate pressure.

genotype the genetic composition of an organism (the set of genes possessed by

it) as distinct from the organisim's characteristics (phenotype).

geomorphology the study of surface landforms.

gibber plains a desert plain covered with red-brown stones derived from stony siliceous tableland cappings.

gilgai surface microrelief in clay soils comprising hummocks and hollows.

Gondwana the southern supercontinent which began to split and move apart about 200 million years ago.

grass short-cells epidermal grass silica accurmulating short cells.

gravimetric analyzed by mass, or data presented as weights or proportions on a mass basis (wt \%).

Great Soil Group Soil classification based on horizon similarity.

gymnosperm primitive seed plants with many fossil representatives. Conifers etc., including Callitris.

gyre large scale surface oceanic circulation. Long-term winds set up major surface currents which circulate clockwise in the north Atlantic and north Pacific

Oceans and anticlockwise in the south Atlantic, south Pacific and Indian Oceans.

halite common or rock salt. Formed by the evaporation of saline water.

halophytic flora plants which tolerate salty soils.

hardpan a hardened layer within a soil profile.

herbivory a process based on the consumption of herbage by animals, both vertebrate and invertebrate.

histology study of tissues.

horizon a layer of soil material differing from adjacent layers in colour, texture, composition, etc. A soil profile consists of one or more horizons labelled from the surface as the $O$ horizon (of decomposing plants), A horizon (top layer of mineral soil), B horizon (usually more clayey than the A), C horizon (weathered parent material) and $\mathrm{D}$ horizon (layers below the soil profile).

hydrology the study of the movement of water on and within the land.

hydrophilous graminoids grass whose habitat is very wet or in water.

incised deepened. Usually when re-juvenation by uplift causes renewed downcutting of a river.

insolation the amount of solar radiation actually received by a surface.

ka thousand years ago.

kurosols (solodized solonetz) (Soil Order, Australian soil classification). Soil with a strong texture contrast between the topsoil and a strongly acid subsoil.

lacustrine of lakes. Lacustrine sediments are those deposited in or around lakes. Last Glacial Maximum (LGM) 25000 to 15000 years ago. 
lithic sandstone sedimentary rock composed predominantly of sand-sized quartz particles cemented by silica or carbonate.

lithology the systematic study of the character of rocks: mineral composition, texture, structures.

lunette a low, gently curved ridge built up by wind on the margin of a playa or intermittent lake.

mallee many stemmed tree or shrub.

MVSP Multi-Variate Statistical Package.

myxomatosis a virus introduced into the rabbit population in Australia in the early 1950 s to reduce the high numbers.

nodules coherent body easily separated from the surrounding soil. May be hard (i.e. iron, manganese) or soft.

oligotrophic soils soils with low nutrient status.

outcrop exposed bedrock.

outwash plain the accumulation of material from glaciation carried out by meltwater, mostly associated with former continental ice sheets (i.e. northem Germany) or from the outwash of a number of valley glaciers (i.e. Canterbury Plains of New Zealand).

palaeochannel ancient channel.

palaeoenvironment past environment

palimpsest relict, but showing the imprint of later conditions.

palynology the study of spores and pollen grains, used to reconstruct past environments.

pan a compact soil layer, denser and less permeable than layers above and below.

Pangaea large supercontinent which, according to Plate Tectonic theory,

contained all of the world's continents and which broke up during the Mesozoic.

ped a natural soil aggregate.

pedogenesis the formation of soils.

pedological of the soil - formation, morphology, distribution and classification.

pH a measure of alkalinity or acidity. A $\mathrm{pH}$ of 7.0 is neutral. Acid values are lower, alkaline values higher.

phylogeny the study of the development or evolutionary history of organisims.

physiology the study of the processes which go on in living organisms.

phytolith assemblages consisting of those phytolith shapes present and their frequency.

phytolith key scheme to identify phytolith shapes.

phytoliths microscopic mineral (opal or calcium) deposits in plants

phytophagus plant-eating.

pisolith a large (3-6 mm in diameter) spherical or subspherical rock particle which

has grown by accretion around a nucleus. These are occasionally found in beds (pisolite).

playa a shallow closed depression intermittently water filled.

pollen assemblages consisting of those pollen shapes present and their

frequency. 
quadrat a sampling area of any shape.

refugia places where organisims are sheltered from change.

runoff the amount of rainwater directly leaving an area in surface drainage.

runways surface moundings of sediment under which termites move.

sand fraction grain size between $2 \mathrm{~mm}$ and $0.02 \mathrm{~mm}$.

sand monkey old river channels filled with sand in the Pilliga State Forests, NSW.

Believed to be derived from an Aboriginal term.

sand splays coarse deposit on a floodplain formed when sand flows through a breach in the river bank during a flood, forming a fan of sand which extends away from the channel.

sandstone rock formed from sand deposited in water.

scalding surface area where the vegetation and topsoil has been removed exposing a subsoil naturally high in salts.

sclerophyllous, plants with stiff, hard leaves.

senescence the gradual breakdown of function and structure due to aging.

sensitivity, the term used to describe a tree with a variable rate of growth through time. This variability in growth is likely to be sensitive to environmental changes of interest, such as climate. It may also result in entirely missing rings in some years.

silt fraction soil particles between 0.002 and $0.02 \mathrm{~mm}$ in diameter.

skeleton plotting the method of converting tree ring counts and width patterns into a visual form for cross-dating. Developed and championed by the International Tree Ring Laboratory.

Sodosols (Soil Order, Australian soil classification.): soil with a strong texture contrast with a $B$ horizon influenced by sodium.

solodic soil soil with a strong texture contrast. The B horizon is tough, hard and dense, the boundary between the A and B is abrupt and the A2 horizon is bleached (near white colouration).

Solodised solonetz (Great Soil Group). Soil with a strong texture contrast and domed structure in the clay B horizon. Alkaline in the lower profile.

source-bordering sand dunes dunes which are composed of material blown from a nearby feature such as a river channel.

stomata small opening in the outermost layer of cells in a leaf which allows exchange of gases.

subsoil the B horizon of a soil in soils with distinct horizons, or the lower soil below the root zone in soils without horizons.

substrate the material below the soil profile.

swale the depression between dunes often having a different soil moisture regime and vegetation than the dune crest.

tectonics study of processes which form the Earth's major structural features e.g. folding, faulting, Plate Tectonics.

Tenosol (Soil Order, Australian soil classification). Soil with weak pedological organization apart from an A horizon; Earthy Sands in older Australian classification. 
texture contrast soil see duplex soil.

TL thermoluminescence dating method of sediment. Thermoluminescence begins to accumulate after burial and a thermoluminescence date determines the time since the sediment was deposited.

tracheid elongated and tapering water conducting and supporting cell in a plant. tree-ring the layer of wood cells produced by a tree or shrub in one year, usually consisting of thin-walled cells formed early in the growing season (called earlywood) and thicker-walled cells produced later in the growing season (called latewood). The beginning of earlywood formation and the end of the latewood formation form one annual ring, which usually extends around the entire circumference of the tree.

TSI acronym for timber standard improvement, a silvicultural treatment which kills unwanted trees by felling, ringbarking or poisoning.

UPGMA a statistical unweighted pair-group method using arithmetic averages used in cluster analysis.

vascular tissue conducting tissue in plants.

Vertosol (Soil Order, Australian soil classification). Cracking clay soil with shrinkswell properties.. Grey Clay in older Australian classification.

weathering profile the layers, including the soil, from the ground surface to the unweathered material below the soil.

wheatfield regeneration dense seedling regeneration.

woody weeds shrubs or trees not valued, growing where unwanted.

$\mathbf{X}$-ray densitometry a system in wood science by which a thin section of wood is $\mathrm{X}$-rayed to produce a density profile from which tree-rings and other density anomalies in the wood can be identified.

XRD X-ray diffraction. The process of identifying mineral structures using X-ray diffraction (interference) patterns. 


\section{Geologic time scale}

\begin{tabular}{|c|c|c|}
\hline Era & Period & $\begin{array}{l}\text { How long ago } \\
\text { (mya }=\text { millions of years ago) }\end{array}$ \\
\hline \multirow[t]{9}{*}{ Cenozoic } & Quaternary & 1.8 mya-present \\
\hline & Pleistocene & 11000 years ago-present \\
\hline & Holocene & 1.8 mya- -11000 years ago \\
\hline & Tertiary & 65-1.8 mya \\
\hline & Pliocene & $5-1.8$ mya \\
\hline & Miocene & $23-5$ mya \\
\hline & Oligocene & $38-23$ mya \\
\hline & Eocene & $54-38$ mya \\
\hline & Paleocene & $65-54$ mya \\
\hline \multirow[t]{3}{*}{ Mesozoic } & Cretaceous & $146-65$ mya \\
\hline & Jurassic & 208-146 mya \\
\hline & Trassic & 245-208 mya \\
\hline \multirow[t]{6}{*}{ Paleozoic } & Permian & $286-245$ mya \\
\hline & Carboniferous & $360-286$ mya \\
\hline & Devonian & 410-360 mya \\
\hline & Silurian & $440-410$ mya \\
\hline & Ordovician & $505-440$ mya \\
\hline & Cambrian & 544-505 mya \\
\hline \multicolumn{2}{|c|}{ Precambrian time } & $4500-544$ mya \\
\hline
\end{tabular}




This volume presents recent advances in the environmental history of Australia's unique, but little known native cypress pine forests of the endemic genus Callitris.

The fifteen species of Callitris span the continent from the tropics, through the semi-arid woodlands to temperate Tasmania. They have survived in Australia for at least a million years. They are famed for their termite-resistant timber and for their aromatic oil. Large areas have been cleared, some areas are being seriously depleted, others are being used for grazing, or are carefully managed in state forests, national parks and nature reserves.

A Million Wild Acres, written by Eric Rolls twenty years ago, introduced its many readers to the history of the largest of the Callitris forests - the Pilliga in New South Wales. Many scientific investigations and heritage studies have followed in the Pilliga and elsewhere.

Here, twenty-four papers report the latest research and writing on Aboriginal burning, the ancient pollen record, landscape formation, regeneration and grazing, forest management, the resurgence of koalas, microscopic secrets in the wood, heritage surveys and much more.

Prepared jointly by the Australian Forest History Society, the Australian National University and Macquarie University, Perfumed Pineries reports a new phase in learning about these fascinating Australian environments. 